Natália Cristine Prado

Ana Carolina Cangemi

(Orgs.)

\title{
ESTUDOS FONÉTICOS E FONOLÓGICOS: OBSERVANDO FATOS LINGUÍSTICOS
}

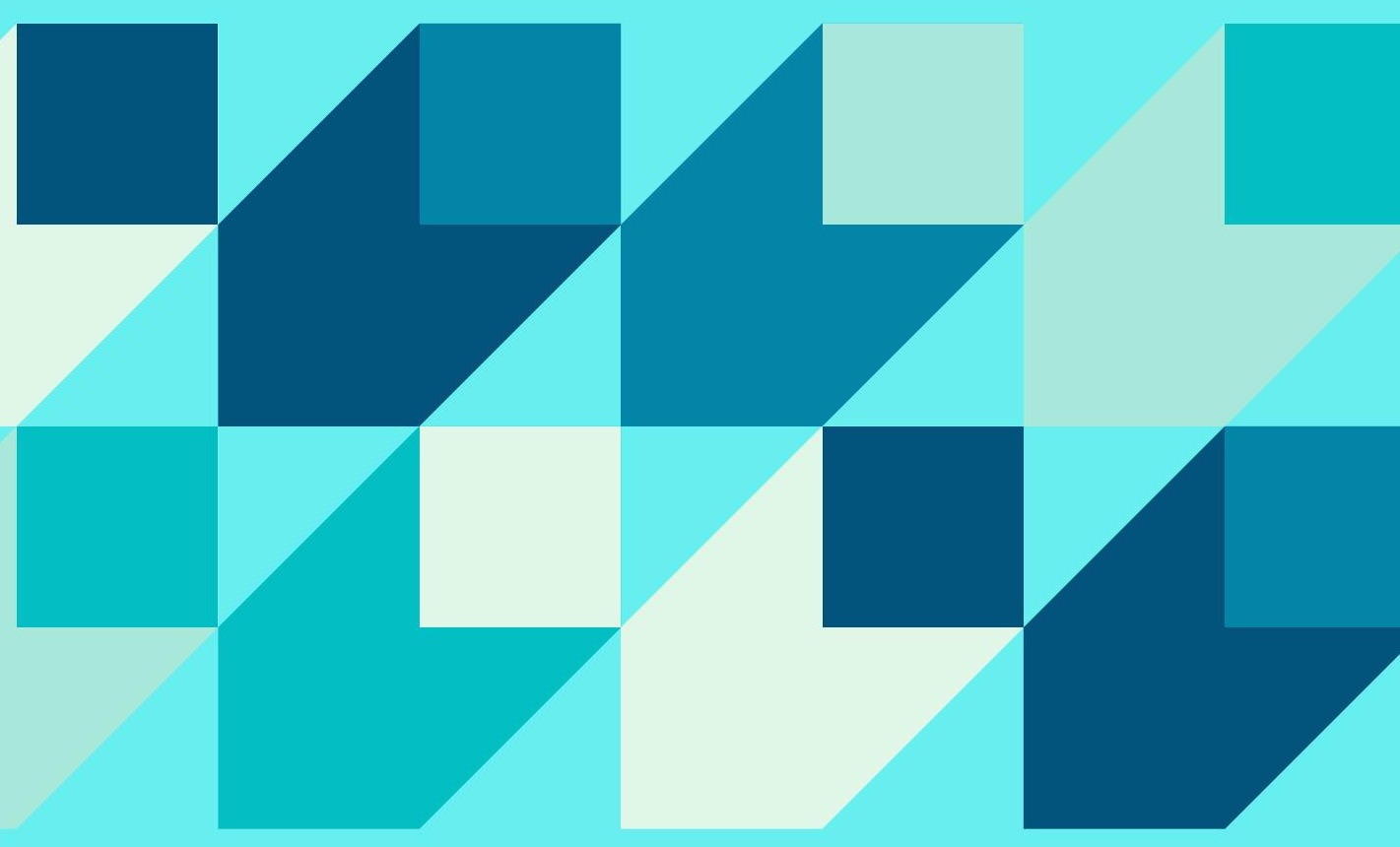

Coleção Pós-Graduação da UNIR

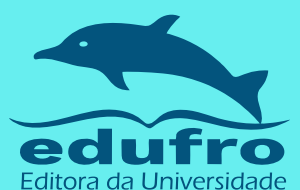




\section{Estudos fonéticos e fonológicos: observando fatos linguísticos}

Natália Cristine Prado

Ana Carolina Cangemi

(Organizadoras) 
FUNDAÇÃO UNIVERSIDADE FEDERAL DE RONDÔNIA

Reitora Marcele Regina Nogueira Pereira

Vice-Reitor José Juliano Cedaro

EDITORA DA UNIVERSIDADE FEDERAL DE RONDÔNIA

CONSELHO EDITORIAL

Presidente Lou-Ann Kleppa

Ariana Boaventura Pereira

Carlos Alexandre Trubiliano

Eliane Gemaque Gomes Barros

Gean Carla Silva Sganderla

Leandro Soares Moreira Dill

Márcio Secco

Marli Lúcia Tonatto Zibetti

Pedro Ivo Silveira Andretta

Ricardo Gilson da Costa Silva

Xênia de Castro Barbosa

\section{COMISSÃO CIENTÍFICA}

Marília Lima Pimentel Cotinguiba

Carlos André da Silva Müller

Gabriel Eduardo Melim Ferreira

Wanderley Rodrigues Bastos

João Paulo Assis Gobo

Patrícia Goulart Tondineli

Lucas Martins Gama Khalil

Quesler Fagundes Camargo

Estevão Rafael Fernandes

Élcio Aloísio Fragoso

Ana Carolina Cangemi

Felipe Flores Kupske

Maria de Fatima de Almeida Baia

Natália Cristine Prado

Paul O'Neill

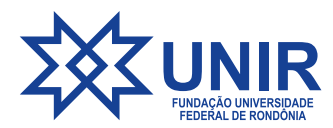

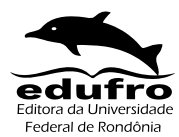

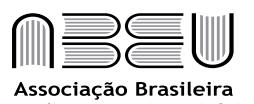
das Editoras Universitárias

Edufro - Editora da Universidade Federal de Rondônia

BR 364, Km 9,5

Campus Unir 76801-059 - Porto Velho - RO

Tel.: (69) 2182-2175

www.edufro.unir.br edufro@unir.br 


\section{Estudos fonéticos e fonológicos: observando fatos linguísticos}

Natália Cristine Prado

Ana Carolina Cangemi

(Organizadoras)

Coleção Pós-Graduação da UNIR

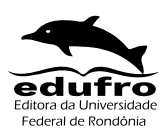

Porto Velho - RO 
(C) 2021 by Natália Cristine Prado, Ana Carolina Cangemi (Organizadoras)

Esta obra é publicada sob a Licença Creative Commons Atribuição-Não Comercial 4.0 Internacional.

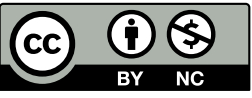

\author{
Capa: \\ Rosivan Diagramação \& Artes Gráficas \\ Revisão: \\ Marília Lima Pimentel Cotinguiba
}

Projeto gráfico:

Edufro - Editora da Universidade Federal de Rondônia

Diagramação:

Rosivan Diagramação \& Artes Gráficas

\author{
Dados Internacionais de Catalogação na Publicação \\ Fundação Universidade Federal de Rondônia (UNIR) \\ Ficha Catalográfica elaborada pela Biblioteca Central da UNIR
}

F981 Fundação Universidade Federal de Rondônia.

Estudos fonéticos e fonológicos: observando fatos linguísticos / organização Natália Cristine Prado, Ana Carolina Cangemi. - Porto Velho, RO: Coleção Pós-Graduação da UNIR - EDUFRO, 2021.

231 p.; il.

ISBN: 978-65-87539-46-1 (digital)

1. Fonética. 2. Fonologia. 3. Prosódia. 4. Linguística. I. Prado, Natália Cristine. II. Cangemi, Ana Carolina. III. Fundação Universidade Federal de Rondônia.

CDU 801.6 


\section{Sumário}

7 REGIÕES BRASILEIRAS: CONTRIBUIÇÕES PARA A ÁREA DE FONÉTICA E FONOLOGIA

Natália Cristine Prado Ana Carolina Cangemi

12 O APAGAMENTO DO RÓTICO EM CODA SILÁBICA NA PRODUÇÃO ESCRITA DE ALUNOS DO ENSINO MÉDIO/EJA DE ESCOLAS PÚBLICAS DE PORTO VELHO-RO

Heloísa Helena Ramos Santos

José Henrique Santos Tavares

Natália Cristine Prado

43 INVENTÁRIO SONORO DA LÍNGUA AIKANÃ̃: REVISÃO DO SISTEMA CONSONANTAL

Patrícia Goulart Tondineli

61 CONTRIBUIÇÕES DA FONÉTICA ACÚSTICA PARA UM DIAGNÓSTICO DIFERENCIAL NA APRAXIA DE FALA

Marian Oliveira

Vera Pacheco

Carolina Lacorte Gruba

Andréia Alves Cordeiro

96 A ENTOAÇÃO NO COMPONENTE FONOLÓGICO DA GRAMÁTICA: HALLIDAY (1970) E PIERREHUMBERT (1980) Luiz Carlos Cagliari

127 A PROSÓDIA MUSICAL COMO PISTA PARA O RITMO LINGUÍSTICO: ANÁLISE DE JINGLES DE PROPAGANDAS TELEVISIVAS Gladis Massini-Cagliari 
151 HIPERSEGMENTAÇÃO E PROSÓDIA: UM ESTUDO DAS FORMAS HIPERSEGMENTADAS DOS ADVÉRBIOS EM -MENTE EM REDAÇÕES ESCOLARES

Ana Carolina Freitas Gentil Almeida Cangemi

Thais Holanda de Abreu-Zorzi

183 A NATUREZA CONSERVADORA DO ACENTO NAS PALAVRAS PAROXÍTONAS TEMINADAS EM CONSOANTE

Luann Dias de Souza

José Magalhães

196 MODELOS DE PERCEPÇÃO DE SONS DE LÍNGUAS NÃO NATIVAS: CONTRIBUIÇÕES PARA A DISCUSSÃO SOBRE PRIMITIVOS FONOLÓGICOS

Ubiratã Kickhöfel Alves

228 SOBRE OS AUTORES (AS) 


\section{REGIÕES BRASILEIRAS: CONTRIBUIÇÕES PARA A ÁREA DE FONÉTICA E FONOLOGIA}

Natália Cristine Prado

Ana Carolina Cangemi

Não é de hoje que a beleza dos sons fala humana encanta e atrai os cientistas da linguagem. A reflexão acerca do aspecto fônico da língua está presente no legado de Ferdinand de Saussure (1974). Com a leitura de Curso de Linguística Geral (doravante CLG), é possível verificar que esse foi um dos principais temas abordados e ministrados de 16 de janeiro a 3 de julho de 1907, na Universidade de Genebra.

Com a perspectiva saussuriana, observamos que, na primeira edição das conferências do CLG, o estudo dos sons das línguas recebe lugar de destaque e a noção de significante - ou imagem acústica - ocupa uma parte importante das aulas de Saussure. Para além do CLG,

é importante dizer que as questões acerca do lugar do fônico no conjunto de reflexões saussurianas ecoam em vários documentos: encontramos rastros de interesse sobre o som nos Escritos de Linguística Geral (2004), no manuscrito Phonétique (1995), no manuscrito das Soantes (2002), no manuscrito Notes sur l'accentuation lituanienne (2003), nos estudos sobre os Anagramas (1974) e já no inaugural Mémoire sur le système primitif des voyelles dans les langues indoeuropéennes (1984). (Milano, 2015, p. 246)

A reflexão sobre a concretude e abstração é ponto de partida para o estudo do fônico: "Esta [a imagem acústica] não é o som material, coisa puramente física, mas a impressão (empreinte) psíquica desse som, a representação que dele nos dá o testemunho de nossos sentidos" (Saussure, 1974, p. 80). Todavia, incorre ao equívoco quem, considerando essa reflexão, separa som de significação. Em Escritos de Linguística Geral (doravante, ELG), lê-se: 
[...] é grandemente ilusório supor que se pode discernir, em linguística, uma primeira ordem: SONS, e uma segunda ordem: SIGNIFICAÇÕES, pela simples razão de que o fato linguístico é fundamentalmente incapaz de se compor de uma só dessas coisas e nunca pede, para existir, uma SUBSTÂNCIA, NEM DUAS substâncias, assim como constatamos que nem o fato mecânico nem o fato acústico, situados cada um em sua esfera, representam o fato fonológico, de que é preciso partir e para o qual é preciso retornar; mas é a forma contínua de sua correlação que chamamos de fato fonológico. (Saussure, 2004, p. 204, grifos do autor)

Assim, o fato fonológico é sustentado pela manutenção simultânea da produção do som e do efeito que ele produz. Neste livro, o leitor encontra estudos das áreas de fonética e fonologia cujo objeto de estudo é o aspecto sonoro, nos diferentes sistemas linguísticos.

Como trata-se de um campo bastante produtivo, tanto em nível nacional quanto internacional, a ideia deste livro não surgiu por uma necessidade de se fomentar as publicações da área, mas, principalmente, com o objetivo de fortalecer, divulgar e estimular as pesquisas fonéticas e fonológicas no Norte do Brasil. Afinal, a maior parte das investigações linguísticas do país ainda se concentra no Sudeste, embora já possamos comemorar o crescimento da área no Norte, pois, segundo dados da CAPES (2019, p. 4), houve um aumento considerável no número de programas de pós-graduação na área de Linguística e Literatura nesta região que

apresenta, atualmente, um conjunto de doze Programas. O Amapá, único estado do Brasil que não possuía um Programa de Pós-Graduação em Linguística e Literatura até a última avaliação quadrienal, teve, em 2018, seu primeiro Programa aprovado. Também nesse período, a Região Norte passou a contar com seus primeiros cursos de doutorado, na UFPA, na UFT e na UFAC.

Neste sentido, é importante registrar um agradecimento ao Programa de Pós-Graduação Mestrado Acadêmico em Letras, sobretudo à atual coordenadora, Marília Lima Pimentel Cotinguiba, e à Pró-Reitoria de Pós-Graduação e Pesquisa da Fundação Universidade Federal de Rondônia (UNIR) 
por apoiarem e incentivarem esta publicação. Aproveitamos também para agradecer a todos os colegas que participaram do Conselho Editorial deste livro cujas leituras prévias e atentas contribuíram com a versão final dos textos apresentados aqui. Ademais, não podemos deixar de agradecer todos os autores que confiaram neste projeto e escreveram os capítulos que compõem esta obra.

Este livro é composto por oito capítulos e traz trabalhos realizados em diferentes cantos do Brasil. Os dois trabalhos que abrem esta coletânea analisam dados da Região Norte, mais especificamente, de Rondônia - estado que possui grande riqueza linguística graças à presença de imigrantes, indígenas, surdos, ribeirinhos e outros povos.

O primeiro capítulo, intitulado $O$ apagamento do rótico em coda silábica na produção escrita de alunos do ensino médio/EJA de escolas públicas de Porto Velho-RO, de autoria de Heloísa Helena Ramos Santos, José Henrique Santos Tavares e Natália Cristine Prado, apresenta uma pesquisa que procura refletir sobre a relação entre oralidade e escrita, mais especificamente, entre fonética, fonologia e escrita, a partir das produções textuais de alunos da Educação de Jovens e Adultos da capital deste estado.

Já o segundo capítulo, escrito por Patrícia Goulart Tondineli, tem por título Inventário sonoro da lingua Aikanã: revisão do sistema consonantal e traz dados importantes sobre os aspectos fonológicos de um idioma indígena brasileiro que corre risco de extinção, além disso, como outras línguas indígenas, encontra-se também em processo de aculturação, com indícios de perda da sua identidade linguística.

Como representantes da região Nordeste, as autoras do terceiro capítulo, intitulado Contribuições da fonética acústica para um diagnóstico diferencial na apraxia de fala, Marian Oliveira, Vera Pacheco, Carolina Lacorte Gruba e Andréia Alves Cordeiro apresentam um estudo das fricativas em posição de onset na fala de um sujeito com Síndrome de Down.

Os quatro trabalhos apresentados a seguir trazem pesquisas realizadas na região Sudeste do país. No quarto capítulo, A entoação no componente fonológico da gramática: Halliday (1970) e Pierrehumbert (1980), o autor Luiz Carlos Cagliari observa que, embora sejam formalmente modelos diferentes de aná- 
lise, a teoria fonológica funcional da entoação de Halliday (1970) e a teoria fonológica gerativa da entoação de Pierrehumbert (1980) não se opõem entre si. $O$ pesquisador mostra os pontos de contato entre as teorias e o elo que pode ser verificado no momento das análises, utilizando as teorias.

No quinto capítulo, de autoria de Gladis Massini-Cagliari, intitulado A prosódia musical como pista para o ritmo linguístico: análise de jingles de propagandas televisivas, há uma aproximação de duas áreas: música e fonologia. O objetivo é buscar contribuições possíveis da da prosódia musical, isto é a organização das proeminências musicais no tempo, em termos de ritmo, e também de melodia, para a determinação da prosódia linguística de períodos específicos do português.

No sexto capítulo, Hipersegmentação e prosódia: um estudo das formas hipersegmentadas dos advérbios em - mente em redaçóes escolares, as autoras Ana Carolina Cangemi e Thaís Holanda de Abreu-Zorzi, abordam a relação entre casos de hipersegmentação e aspectos prosódicos do português brasileiro, em redações escolares, por meio da observação e do mapeamento das ausência e presença de fronteiras gráficas.

O sétimo capítulo intitulado $A$ natureza conservadora do acento nas palavras paroxitonas terminadas em consoante, cujos autores são Luann Dias de Souza e José Magalhães, revisita estudos sobre o acento nominal do português. Interessa, aos autores, observar as palavras paroxítonas terminadas em consoante, principalmente as de origem latina, uma vez que, por ser vocábulos marcados, quanto à acentuação, contrariariam o argumento de que o português seja sensível ao peso quando a sílaba final é dotada de rima ramificada.

Por fim, no oitavo capítulo há uma pesquisa realizada no Sul do Brasil. No texto Modelos de percep̧çao de sons de linguas não nativas: contribuições para a discussão sobre primitivos fonológicos de Ubiratã Kickhöfel Alves, o autor reflete sobre três propostas perceptuais de Segunda Língua (L2), desenvolvidas à luz da Fonologia de Laboratório. Ele conduz uma interessante discussão, mostrando ao leitor que as propostas variam por atribuir mais ênfase ou à representação, ou aos mecanismos de formalização da gramática. 
Finalmente, reforçamos nosso agradecimento a todos os envolvidos nos vários processos prévios à publicação deste livro, e na expectativa de que essa coletânea possa incentivar e inspirar novas pesquisas fonéticas e fonológicas, sobretudo no Norte do país, desejamos uma boa leitura!

\section{REFERÊNCIAS}

BRASIL. Ministério da Educação (MEC). Coordenação de Aperfeiçoamento de Pessoal de Nível Superior (CAPES). Diretoria de Avaliação (DAV). Documento de Área: Área 41: Linguística e Literatura. Brasília: CAPES, 2019.

HALLIDAY, M. A course in spoken English: intonation. London: Oxford University Press., 1970.

MILANO, L. Fonético e fonológico em Saussure: o lugar do fônico no Curso de Linguística Geral. Eutomia, Recife, 16 (1): p. 245-258, Dez. 2015

PIERREHUMBERT, J. Phonetics and phonology of English intonation. Ph.D. dissertation. MIT. 1980. (Published by Garland Press, New York, 1990).

SAUSSURE, F. Curso de Linguística Geral. São Paulo: Cultrix, 1974.

. Escritos de Linguística Geral. São Paulo: Cultrix, 2004.

. Phonétique: Il manoscritto di Harvard. Padoue: Unipress, 1995.

.Théorie des sonantes: Il manuscritto di Geneva. Padoue: Unipress, 2002.

. Notes sur l'accentuation lituanienne. L'Herne Saussure. Paris: Editions de l'Herne, 2003.

Recueil des publications scientifiques. Genebra: Slaktine, 1984. 


\title{
O APAGAMENTO DO RÓTICO EM CODA SILÁBICA NA PRODUÇÃO ESCRITA DE ALUNOS DO ENSINO MÉDIO/ EJA DE ESCOLAS PÚBLICAS DE PORTO VELHO-RO
}

\author{
Heloísa Helena Ramos Santos \\ José Henrique Santos Tavares \\ Natália Cristine Prado
}

\section{Introdução}

A aprendizagem da escrita é um dos principais objetivos do processo de escolarização dos indivíduos, já que, ao dominar essa modalidade da língua, o estudante pode ampliar seus conhecimentos gerais a partir da leitura de livros, por exemplo. Além disso, aprender a escrever pode impactar positivamente na desenvoltura comunicativa das pessoas, o que certamente ajuda na inserção social. É importante destacar que, ao chegar na escola, os alunos já trazem uma bagagem linguística, ou seja, já têm conhecimentos internalizados sobre o uso de sua língua materna, sobretudo, em sua modalidade oral. Assim, é natural que a aquisição da língua escrita seja permeada pela influência da oralidade, sendo essa interferência, em alguns casos, a responsável por alguns desvios comumente encontrados nos textos escritos.

Partindo dessas considerações iniciais, entende-se que observar as relações que se estabelecem entre fonética, fonologia, variação linguística e escrita nas produções textuais de estudantes mostra-se importante para compreender como se dá o processo de construção de conhecimento linguístico desses alunos, bem como para identificar os aspectos que são migrados da oralidade para a escrita. Assim, considerando essa relação, neste estudo, investiga-se o processo fonológico de apagamento do rótico em coda silábica, tanto em posição medial quanto no final de palavras (verbos e não verbos), nos textos produzidos por estudantes matriculados no $1^{\circ}$ ano do ensino médio da Educação de Jovens e Adultos (EJA).- 
Para esta pesquisa, foram coletados 80 textos de estudantes de EJA em Porto Velho (RO). A observação de dados produzidos por alunos advindos da Educação de Jovens e Adultos não é comum em trabalhos dessa natureza, visto que a maioria é voltada para as práticas alfabetizadoras de leitura e escrita sem identificar o contexto e o viés das variantes linguísticas. Entretanto, acreditamos que, por se tratar de uma modalidade educacional indicada para os indivíduos que não frequentaram a escola em idade regular (dos 6 aos 14 anos), pode ser interessante analisar a presença de processos fonológicos nessas produções textuais, o que nos permitirá refletir sobre as relações entre fala/ escrita e oralidade/letramento no processo de aquisição da escrita desse público específico. Ao longo deste capítulo, são analisadas 107 ocorrências do fenômeno supracitado. Segundo Oliveira (2009) e Mendes e Oushiro (2014), o apagamento da consoante rótica, no português brasileiro atual, ocorre devido a variações dialetais, sendo, portanto, a região na qual está inserido o estudante um elemento importante para se estabelecer uma reflexão sobre esse fenômeno.

Quanto à apresentação, este capítulo foi dividido em cinco seções. $\mathrm{Na}$ primeira, aborda-se o letramento no contexto da EJA, que objetiva situar o leitor sobre o universo dessa modalidade educacional. Na seção seguinte, buscou-se apresentar as concepções teórico-metodológicas sobre fonética, fonologia, escrita e ortografia, refletindo a relação estabelecida entre elas inerentes ao processo de construção de ensino e aprendizagem dos educandos da EJA.

Compreendidos os aspectos teóricos basilares, a terceira seção trata do fenômeno de apagamento do rótico, objeto central deste estudo, abarcando os principais fatores linguísticos e extralinguísticos que contribuem para sua incidência. $\mathrm{Na}$ quarta seção, apresentam-se o lócus da pesquisa, os métodos utilizados para o levantamento das informações e os registros textuais, a abordagem para a análise dos dados e os resultados obtidos.

Por fim, apresentamos as principais conclusões encontradas por meio deste estudo, evidenciando a importância de se refletir sobre os processos que levam ao fenômeno de apagamento do rótico na escrita, uma vez que a sua compreensão permite ao pesquisador não só analisar a relação entre oralidade e escrita, como pensar sobre possibilidades metodológicas para se obter me- 
lhores resultados no processo de ensino e aprendizagem da língua materna, em especial, na Educação de Jovens e Adultos, respeitando a diversidade e os saberes dos alunos dessa modalidade.

\section{O letramento no contexto da Educação de Jovens e Adultos}

Apesar dos avanços da educação brasileira na contemporaneidade, o processo de ensino e aprendizagem da leitura e da escrita não tem alcançado um patamar que possibilite garantir a inserção social integral das pessoas que concluem seus ciclos de estudo (INEP, 2016). Tal aspecto se agrava ainda mais quando se verificam os números advindos da EJA, a qual recebe um público que, por inúmeros fatores, não teve acesso à educação em idade regular. Segundo Brito (2011), a EJA adquiriu, após a edição da Lei de Diretrizes e Bases de 1996 (LDB/96), o formato de um processo educativo voltado para o atendimento daqueles com problemas históricos de exclusão social e dos direitos básicos de cidadania.

O Conselho Nacional de Educação, por meio do Parecer CNE/CEB n. $11 / 2000$, já havia, àquela época, retratado o perfil do estudante da EJA como aquele composto por "adultos ou jovens adultos, via de regra mais pobres e com escolaridade defasada. Estudantes que aspiram a trabalhar, trabalhadores que precisam estudar" (CNE/CEB, 2000, p. 9).

Para fins de entendimento quanto ao perfil que retrata a realidade da EJA, pautamo-nos nos ensinamentos de Arroyo (2005, p. 22) ao dizer que os indivíduos que buscam a EJA são "jovens e adultos com rosto, com histórias, com cor, com trajetórias sócio-étnico-racial, do campo e da periferia”. Assim, o ambiente escolar deve atuar como um local que permita o acesso ao conhecimento por meio de reflexão e práticas metodológicas que respeitem as diferenças de seus alunos, ofertando múltiplas possibilidades para que esses alcancem um desempenho satisfatório, de acordo com as suas capacidades e individualidades.

De acordo com a estimativa apresentada pela Pesquisa Nacional por Amostra de Domicílios Contínua de 2018 (PNAD), a taxa de analfabetismo das pessoas com 15 anos ou mais foi estimada em 6,8\%, mostrando uma redução em relação ao percentual levantado em 2017, que era de 7\%. No entanto, os números de 2018 ainda se mostram preocupantes, uma vez que correspondem a 11,3 
milhões de analfabetos no país. Outro dado trazido pelo PNAD 2018 refere-se à distribuição nas regiões que compõem o país, de forma que a região Norte, lócus desta pesquisa, contou com taxa estimada em 8,0\%, a segunda maior no país.

Para Galvão e Soares (2006), o indivíduo que busca a EJA, normalmente, pertence às camadas sociais menos favorecidas da população, por isso, não teve a oportunidade de estudar em idade regular. Os obstáculos que impedem tal acesso, aqui apontados como desafios a serem superados, são representados principalmente: a) pelas noções aplicadas de alfabetização de forma mecanicista, em detrimento dos processos de produção e compreensão; b) pelo despreparo do professor para atuar junto à EJA devido à inexistência de cursos de formação adequados e c) pelas condições dos estudantes, sejam elas socioculturais, de linguagem, de comunicação e vivência.

De acordo com Soares (2006, p. 18), letramento é "o resultado da ação de ensinar ou de aprender a ler e escrever: o estado ou a condição que adquire um grupo social ou um indivíduo como consequência de ter-se apropriado da escrita”. Nesse sentido, a autora busca enfatizar que a noção de letramento não deve ser entendida somente como uma prática social relacionada ao uso da escrita e da leitura, a partir da habilidade das pessoas de decodificar as palavras, mas, sim, sobre a capacidade do indivíduo de, para além da leitura e escrita, saber inserir tais habilidades nas práticas sociais do seu cotidiano de maneira adequada.

Diante da concepção e relevância que o letramento possui para a formação do cidadão, Brito (2011), em seus estudos sobre o letramento no contexto da EJA, reflete, ainda, sobre a necessidade da realização de novos estudos sobre a temática, visto que:

[...] as pesquisas neste nível sempre estiveram mais voltadas para as concepções pedagógicas e políticas públicas voltadas para a EJA, quase sempre diagnosticando o status que a EJA vinha ganhando no contexto escolar, em detrimento dos processos ou mecanismos que ocorrem no seio da escola que pudessem promover as mudanças pretendidas com esta nova modalidade de ensino, bem como os ganhos e vantagens preconizados pela legislação atual mediante as passagens destes sujeitos pelas classes destinadas a esta modalidade de ensino. (Brito, 2011, p. 27). 
Nesse enfoque, passa-se a compreender o letramento a partir da ideia de um conjunto de práticas culturais que são constantemente redefinidas, seja de acordo com o contexto ou a ordem social estabelecida, em que as construções dos discursos, são formadas a partir da maneira da qual se utilizam os conhecimentos adquiridos e da vinculação destes com o meio. Com isso, verifica-se que o contato com discursos e identidades culturais variadas em âmbito local, regional e/ou global se mostra essencial para a formação do indivíduo, uma vez que o letramento efetivo das pessoas ocorre a partir das interações vivenciadas.

A partir dessa perspectiva, o letramento passa a ser percebido, para fins desta pesquisa, como uma prática social concebida a partir de linguagens, habilidades e conhecimentos variados que o sujeito possui sobre a leitura, escrita e sua utilização, que incorrem na necessidade de modelos variados de ensino e aprendizagem, dentro e fora do ambiente escolar. Assim, concordamos com Brito (2011, p. 28) para quem o letramento "não se restringe apenas às práticas de leitura e escrita no âmbito da sala de aula, aquelas que são feitas a partir do livro didático, mas às práticas de leitura e escrita que estes sujeitos exercem no seu cotidiano”.

\section{Fonética, Fonologia, Escrita e Ortografia}

Estudar questões ortográficas e suas relações com a fonética e a fonologia do português pode ser interessante para perceber as diferentes nuances da aquisição da escrita no contexto educacional. Diante disso, este estudo está centrado no processo formativo dos textos de alunos da EJA matriculados na $1^{\text {a }}$ série do ensino médio de escolas de Porto Velho (RO) e na verificação do apagamento de róticos.

Relevante se faz compreender os principais conceitos que darão suporte ao objeto desta pesquisa sobre o fenômeno variável supracitado e que pode ocorrer em diferentes posições silábicas. Assim, parte-se das concepções estruturalistas formuladas por Câmara Jr. (1970) sobre Fonética e Fonologia, que, a partir da dicotomia apresentada por Saussure ${ }^{1}$, distinguiu-as como sendo a

${ }^{1}$ Ferdinand de Saussure, no período de 1907-1910, em seu Curso de Linguística, ministrado na Universidade de Genebra, introduziu diversas dicotomias para a compreensão das questões linguísticas. 
Fonética: a ciência que trata dos sons da fala (produção, propagação e percepção) e a Fonologia, aquela que versa sobre os sons da língua.

Ao tratar da Fonética, dos modos como os sons são produzidos e percebidos e quais são os elementos constitutivos da sua produção, verifica-se que essa ciência se encontra situada em três domínios distintos, quais sejam: a) Fonética Articulatória (fisiologia dos sons - classifica e descreve os sons); b) Fonética Acústica (propriedades físicas dos sons - como se propaga) e c) Fonética Auditiva (percepção dos sons).

Já o estudo da Fonologia pauta-se, de acordo com Câmara Jr. (1970), nos sistemas e padrões que os sons possuem, sendo importante destacar os dois níveis de Fonologia ao classificarmos os componentes que compõem essa ciência, são eles: o nível da Produção do Discurso, em que se localizam os sons que falamos e escutamos, e o nível do Conhecimento Fonológico, cuja sequência de sons é baseada no conhecimento do sistema fonológico que falantes e ouvintes possuem de uma determinada língua ou variante linguística; nesse nível, o grupo de sons se dá de forma consistente de sentido e observa 'regras' de utilização para a formação de palavras.

Não há, portanto, como abordar questões de fonologia no português brasileiro sem apresentar os ensinamentos de Câmara Jr. (1970), uma vez que foi ele o primeiro estudioso brasileiro a apresentar uma análise da fonologia do português do Brasil (Leite, 2004). Todavia, conforme Leite (2004), importante se faz:

[...] uma caracterização mais ampla da teoria seguida por Mattoso Câmara. Ele foi adepto, talvez o único em nosso país, da fonologia do Círculo Linguístico de Praga, cujos ensinamentos fora aprimorar nos Estados Unidos da América em 1943, com uma bolsa de estudos conferida pela Fundação Rockefeller. Foi aluno, tornando-se amigo, de Roman Jakobson. É essa fase de seu curriculum acadêmico, esse período de maturação linguística, que ele nos traduz em Para o Estudo da Fonêmica Portuguesa. [...]. Assim, o quadro por ele apresentado do sistema vocálico é um exemplo de clareza de aplicação de uma teoria. Parte das oposições em posição tônica, estabelecendo 7 fonemas, que irão se neutralizar nas posições átonas: 5 arquifonemas na posição pré-tônica, 4 na posição pós-tônica medial e 3 na posição 
pós-tônica em final de palavra. A realização dos arquifonemas irá depender dos dialetos regionais, sendo que na posição pré-tônica a regra de alteamento das vogais médias tornará os contrastes pouco produtivos. Oferece-nos, deste modo, uma visão global e integradora. (Leite, 2004, p. 15).

Diante disso, verifica-se que a contribuição fonológica de Câmara Jr. é, indubitavelmente, um dos motivos que o mantém conhecido até os dias atuais nos meios acadêmico-científicos, nas pesquisas voltadas para o estudo de línguas. Referida importância também se constata nos estudos de Bisol (2003, 2004, 2013), que defende a necessidade contínua dos estudos a partir dos aspectos destacados por Câmara Jr. (1970).

Um dos destaques apresentados por Bisol (2004) sobre os escritos de Câmara Jr. refere-se à distinção feita por ele sobre palavra morfológica e palavra fonológica. Assim, de acordo com a autora, enquanto a palavra morfológica "compreende palavras lexicais, como nome, adjetivo e verbo, classes abertas, e palavras funcionais como preposição, conjunção e determinativos, classes fechadas", a palavra fonológica se caracteriza por distinguir "palavras com acento e sem acento" (Bisol, 2004, p. 59).

Tal entendimento encontra suporte em Câmara Jr. (1970, p. 35), quando o autor afirma que "em português, o vocábulo fonológico depende da força de emissão das suas sílabas. Essa força é que se chama acento.", questão que será aprofundada no tópico 3 deste estudo.

Também se faz importante estabelecer como a fonética e a fonologia atuam sobre o fenômeno do letramento. Nesse sentido, buscamos suporte em Frago (1993), que mostra a necessidade de:

[...] unir de novo oralidade e escrita. A linguagem escrita não é uma imitação ou arremedo do oral. Tem seu caráter e virtualidades próprias. Mas deve assentar-se e crescer numa cultura oral não desvalorizada, mas enriquecida, assim como nas experiências e relações com o oral e o escrito anteriores ou coetâneas, mas sempre exteriores à escola. Isto é, na história e vida do analfabeto, a fim de facilitar sua reescritura, uma diferente narração - reflexão - dessas histórias e vida. (Frago, 1993, p. 27). 
Dessa forma, se agregarmos ao pensamento de Frago (1993), a perspectiva do letramento, que integra, para além das questões técnicas, os aspectos sociais, verifica-se que a formação oral e escrita dos educandos encontra uma relação de interdependência com a sociedade na qual se encontram inseridos, fazendo com que sofram influências culturais, sociais, econômicas e políticas.

Referido pensamento coaduna com os ensinamentos de Soares (2010, p. 18), ao mostrar a importância de que “[...] o enfoque da língua escrita como um meio de expressão/compreensão, com especificidade e autonomia em relação à língua oral [...] ocorra mediante a observação dos [...] determinantes sociais das funções e fins da aprendizagem".

Para Soares (2010), o processo de ensino e aprendizagem da leitura e da escrita decorre das relações entre Fonética e Fonologia, destacando ainda que:

[...] como não há correspondência unívoca entre o sistema fonológico e o sistema ortográfico na escrita portuguesa (um mesmo fonema pode ser representado por mais de grafema, e um mesmo grafema pode representar mais de um fonema), o processo de alfabetização significa, do ponto de vista linguístico, um progressivo domínio de regularidades e irregularidades. (Soares, 2010, p. 21).

Assim, verifica-se o fenômeno do letramento como distinto da concepção de alfabetização, uma vez que um sujeito pode ser letrado e não ser alfabetizado ou ser alfabetizado e não letrado. Isso porque, a partir das idiossincrasias dos fenômenos de letramento e alfabetização, cada um pode acontecer de maneira individualizada ou, até mesmo, dissociada, conforme ensina Tfouni (1997):

O sujeito do letramento [...] não é necessariamente alfabetizado. Isso significa que nem sempre estão ao seu alcance certas práticas discursivas que se materializam em portadores do texto específicos (na modalidade escrita, portanto), cujo domínio é fundamental para a efetiva participação nas práticas sociais. Existe um processo de distribuição não homogêneo do conhecimento, o qual produz tanto a participação quanto a exclusão. Sem dúvida, a exclusão é maior no caso do sujeito letrado não-alfabetizado. (Tfouni, 1997, p. 86). 
Pode-se depreender então que a natureza do fenômeno do letramento é complexa, o que, nas palavras de Schwindt et al. (2007), refere-se a uma via de mão dupla, em que a oralidade influencia a escrita, ao mesmo tempo que a escrita apresenta função determinante sobre a fala, de forma que inúmeros serão os aspectos que irão influenciar o processo do letramento. É demonstrado, assim, que não é possível existir ainda, por exemplo, duas ou mais línguas que possuam sistema fonológico idêntico, uma vez que é esse sistema o responsável por constituir a identidade da língua. Nesse sentido, a título de exemplo, ainda que a língua portuguesa e a italiana possuam os fonemas idênticos, diferentes serão os sons produzidos por suas realizações de fala.

Com isso, verifica-se, de acordo com Marcuschi (2008), que:

A fala (enquanto manifestação da prática oral) é adquirida naturalmente em contextos informais do dia-a-dia e nas relações sociais e dialógicas que instauram desde o momento em que a mãe dá seu primeiro sorriso ao bebê. Mais do que a decorrência de uma disposição biogenética, o aprendizado e o uso de uma língua natural é uma forma de inserção cultural e de socialização. Por outro lado, a escrita (enquanto manifestação formal do letramento), em sua faceta institucional, é adquirida em contextos formais: na escola. (Marcuschi, 2008, p. 18).

Depreende-se, pois, de acordo com esse autor, que o estudo da fonética e da fonologia se mostra essencial para a compreensão dos fenômenos que se apresentam nas práticas sociais de oralidade e de letramento, tema abordado nesta pesquisa. Nessa esteira, para uma interpretação e análise mais adequada ao fenômeno do rótico, não se pode deixar de lado a compreensão dos aspectos fonéticos e fonológicos presentes nos estudos das variações na Língua Portuguesa (Callou; Leite, 2009).

Assim, seja em posição média ou final de coda, a pronúncia dos rótico pode sofrer variações na fala, desde a manutenção da sua articulação vinculada ao contexto fonológico até o seu total apagamento. Conforme se verifica nos exemplos constantes do item 5 deste capítulo, essas variações também podem ser verificadas nas produções textuais de alunos em processo de aquisição e 
amadurecimento da escrita. Dessa forma, outra distinção importante a ser apresentada refere-se às concepções sobre a escrita (grafia) e a ortografia, em que se tem, como escrita, a representação gráfica de uma palavra, sua escrita e/ ou transcrição, podendo ainda ser compreendida como as formas possíveis de representar uma palavra por escrito, inclusive, as consideradas socialmente incorretas e as antigas como: casa (grafia correta) e caza (grafia incorreta); farmácia (grafia atual) e pharmacia (grafia antiga) ou as decorrentes da transcrição fonética da fala, por meio de um alfabeto convencional estabelecido.

Já, de acordo com o que consta do Dicionário Houaiss, a ortografia pode ser definida como:

[...] conjunto de regras estabelecidas pela gramática normativa que ensina a grafia correta das palavras, o uso de sinais gráficos que destacam vogais tônicas, abertas ou fechadas, processos fonológicos como a crase, os sinais de pontuação esclarecedores de funções sintáticas da língua e motivados por tais funções etc. (Azeredo, 2014, p. 44).

Advinda do grego, em que ortho quer dizer correto e grafo, por sua vez, significa escrita, pode-se inferir que a Ortografia é a parte da Gramática responsável por estudar a forma correta de escrita das palavras de uma língua.

Não obstante, outro elemento importante a ser considerado na escrita refere-se ao fenômeno da fala que integra o texto escrito, evidenciando, assim, o funcionamento da modalidade oral nos textos escritos, que justifica a necessidade de ampliação dos estudos sobre a presença da oralidade no ensino de língua portuguesa e as variações linguísticas existentes (Silva, 2016).

Constantemente verificada, a modalidade oral se faz presente em textos escolares escritos e, ainda que cada tipologia (oral e escrita) seja imbuída de elementos singulares, suas diferenças, conforme Marcuschi (2008), são definidas pelos usos e não pelo sistema, ou seja, não se trata de distinções dicotômicas, mas, sim, a partir das distintas perspectivas dos gêneros textuais analisados, o que no caso das turmas da EJA, devido a sua característica heterogênea em relação ao perfil de alunos - jovens, adultos e idosos - com necessidades e motivações diversas, apresentam-se de forma mais acentuada. 
Nesse cenário, pautamos nossos estudos a partir da concepção apresentada por Tarallo (2001, p. 8), que entende as variantes linguísticas como sendo as "diversas maneiras de se dizer a mesma coisa em um mesmo contexto, e com o mesmo valor de verdade". Com isso, a ocorrência, por exemplo, de um processo fonológico na construção textual pode acarretar em desvios na escrita, o que, de acordo com Cagliari (2008, p. 61), levará o aluno a errar "na forma gráfica porque se baseia na fonética."

Assim, os desvios de escrita - socialmente convencionados como erros gerados por influência da oralidade, dentro do contexto fonológico, mostram-se como um modo do educando representar, na forma escrita, uma opção diferente daquela constante das regras ortográficas, em face das variantes possíveis das quais ele dispõe para se expressar, fornecidas pelos recursos da escrita.

Nesse sentido, Corrêa (2007) conclui, em seus estudos sobre as marcas enunciativo-discursivas, que:

[...] fica marcada, portanto, a miscibilidade das práticas sociais e dos gêneros discursivos, permitindo que olhemos para certas presenças surpreendentes de fragmentos de gêneros, manifestadas em diferentes dimensões da linguagem, não como erro nem como inadequação, mas como um registro pontual e singular, porque histórico, do estado do processo discursivo em que o sujeito se situa no que se refere, especificamente, ao posicionamento enunciativo que ocupa em relação aos modos de enunciação falado e escrito. (Corrêa, 2007, p. 272).

Para o autor, será a partir da abordagem da relação entre o texto escrito (produto), da forma como se desenvolveu a escrita (processo) e da disponibilização de ideias adequadas e significativas (saber internalizado e acesso a informações adequadas) que o texto do educando, para além de representar uma prática de escrita, poderá ser concebido como sua forma de representar suas convicções.

\section{Revisando o fenômeno de apagamento do rótico}

Verifica-se, nos estudos sobre a fonologia da língua portuguesa, que o arquifonema $/ \mathrm{R} /$ está entre os quatro existentes que podem se localizar em posição de coda silábica, seja final ou medial, que leva à ocorrência de variações, como a do apagamento ora em estudo. 
Estudiosos têm concentrado suas pesquisas sobre a variação do rótico na língua falada em posição final das palavras e os trabalhos têm revelado que o apagamento desse fonema em posição pós-vocálica final é praticamente categórico. Entretanto, o fenômeno do apagamento do rótico em posição de coda silábica vem avançando para o contexto medial, o que pode ser notado principalmente na fala de indivíduos que utilizam normas populares do português do Brasil. (Costa, 2009, p. 2009).

Botassini (2011) comprova que o apagamento desta consoante raramente ocorre em posição interna de palavra e demonstra que o apagamento do /R/ final ocorre com uma maior incidência nas falas de informantes com o nível de escolaridade menor.

No caso do rótico, é possível verificar em face das variações linguísticas regionais, por exemplo, o fato de que cada região do país apresenta uma determinada incidência da realização do rótico em relação à posição de coda.

Trata-se de um fenômeno que ultrapassa os limites da língua nacional, pois, de acordo com estudos realizados por Hora e Monaretto (2003), na década de 1980, quase $60 \%$ das línguas conhecidas já continham a presença de algum tipo de rótico em seu sistema linguístico, sendo que 20\% delas contavam com mais de uma variável.

Segundo Cardoso (2009, p. 194-195),

Em todas as regiões do Brasil, o /R/ pós-vocálico, independentemente da forma como é pronunciado, tende a ser suprimido, especialmente nos infinitivos verbais (amar > amá; saber > sabê; sentir > senti), nas formas do futuro do subjuntivo: (se eu estiver > estivé; se ele quiser > quisé; se ela fizer > fizé), nos substantivos (amor > amô); nos adjetivos (melhor > melhó); e nos advérbios (devagar > devagá)).

Sobre o apagamento do rótico no Brasil, Callou (1987) já verificava, em seus estudos, no final da década de 1980, índices consideráveis do fenômeno, que, desde então, estão em constante aumento e identificação em todo o território nacional. Bortoni-Ricardo (2004, p. 85) afirma que "o falante da língua, quando suprime um $\mathrm{r}$ em infinitivo verbal ao escrever, faz isso porque na língua oral ele já não usa mais esse r". 
Sobre essa temática, Câmara Jr. (1970) já mostrava, em seus trabalhos, a existência de variações posicionais e livres, sendo esta última a que melhor se enquadra para o presente caso. De acordo com o autor, a variante livre ocorre de acordo com o uso em determinada comunidade linguística - grupo social e/ou região - e:

[...] estão neste último caso os alofones do /r/ chamado "forte", que pode ser uma vibração prolongada da ponta da língua junto aos dentes superiores ("r" múltiplo), ou uma vibração da língua junto ao véu palatino ("r" uvular), ou uma forte fricção da faringe (" $r$ " fricativo não-lingual, foneticamente semelhante ao $/ \mathrm{h} /$ aspirado inglês, onde simplesmente não há na faringe nenhuma fricção). Os alofones, ou variantes, livres são, em termos diacrônicos, em regra, mudanças fonológicas em andamento. Assim, a variação do /r/ forte, em português, indica um processo de mudança da articulação anterior (na parte anterior da boca, junto aos dentes) para uma articulação posterior (na parte posterior da boca, a partir do véu palatino), que ainda não terminou. (Câmara Jr., 1970, p. 27).

O rótulo "vibrante" foi com o tempo substituído para "rótico", visando atender às formas preferenciais dos falantes, de modo a agrupar o estudo em um tópico, de acordo com o lugar que esses fonemas ocupam, isso porque se tem observado que as mudanças do ponto de articulação do rótico identificadas nos últimos tempos tornam-se significativas para a compreensão do processo de ensino e aprendizagem dos estudantes, de forma que seja possível observar suas características intrínsecas e retirar a carga negativa da qual o apagamento do rótico era fator representativo e segregativo (Callou, 1987).

A importância apontada por Callou (1987) busca eliminar as concepções anteriores que circulavam entre os estudiosos da língua portuguesa das décadas de 1950 a 1980, de que o apagamento do /R/, em especial, no final de sílaba, era tido como um "vulgarismo" (Silva Neto, 1950) ou, ainda, se associava a pessoas de baixa escolaridade e condições socioeconômicas (Houaiss, 1985).

Segundo Oliveira e Prado (2020), o apagamento do rótico é influenciado por fatores linguísticos e extralinguísticos, visto que, ao relacionar esse fenômeno 
fonológico ao processo de desenvolvimento da escrita, demonstram a sua relevância, já que os estudantes têm o contato com a oralidade durante toda a vida escolar. Sobre o fenômeno do apagamento Oliveira (1983) afirma que:

a) o apagamento é muito mais frequente e saliente em posição de final de palavra do que no interior da palavra;

b) sua ausência em final de palavra é mais comum em verbos do que em não-verbos;

c) de acordo com alguns relatos, o apagamento está relacionado a falantes de classe mais baixa e é considerado um vulgarismo;

d) o apagamento é um processo variável, sujeito a condicionamento fonológico. (Oliveira, 1983, p. 93).

Assim, a partir da análise da ocorrência do fenômeno ora abordado, busca-se fomentar o debate sobre a sua contínua e crescente aparição nas variadas regiões do país, sendo possível, ainda, a partir da análise do contexto, da aparição em coda medial ou final, verificar se o comportamento do rótico, no lócus desta pesquisa, está em consonância com os estudos e evolução das variações linguísticas.

\section{Metodologia e análise dos dados}

A pesquisa foi realizada em duas escolas públicas situadas na cidade de Porto Velho (RO), que serão denominadas escolas A e D, com turmas de alunos da $1^{\mathrm{a}}$ série do ensino médio da EJA. Para tanto, foram selecionados textos de amostragem da seguinte forma: da escola A, 41 textos sob a tipologia discursiva gênero textual 'Crônica Narrativa' e, na escola D, 39 textos descritivos sob o gênero 'Relato de Experiência'.

Trata-se de um estudo que parte da descrição dos róticos em contextos de textos dissertativas de alunos do EJA. Após a descrição, os dados coletados são analisados no âmbito das áreas e das teorias de base fonética e fonológica. Cabe ressaltar que não é um estudo sociolinguístico, uma vez que não se busca, neste trabalho, correlacionar aspectos linguísticos e sociais, mas sim verificar 
as marcas da oralidade nos textos escritos em função do apagamento do rótico - fenômeno encontrado em diferentes regiões do Brasil, assim como em Porto Velho-RO. A opção por escolas em bairros distintos - Bairro Eldorado e Bairro Esperança da Comunidade - e distantes visou possibilitar o acesso a textos de alunos com realidades sociais diversificadas.

A coleta dos dados consistiu na aplicação de uma atividade cuja proposta era a produção textual do gênero dissertativo e descritivo, conforme já citado, observado o grau de instrução dos alunos. Também foram providenciados os Termos de Compromisso Livre Esclarecido (TCLE), documento este que contou com todas as informações sobre a pesquisa, além de informar que os nomes dos informantes seriam preservados por meio de códigos, como: "Informante 01 - Escola A". No total, foram produzidos 80 textos.

Para fins da análise dos dados, foram selecionadas as palavras com apagamento do rótico, divididas em verbos e não verbos, por serem as incidências de maior representatividade, apresentando-se a forma convencional e a incidência por sexo e por informante.

\section{Resultados}

O material linguístico foi constituído do recorte de palavras - verbos e não verbos - que foram identificadas junto aos textos dos alunos sujeitos desta pesquisa ${ }^{2}$, culminando no destaque das palavras abaixo indicadas, separadas por "apagamentos em verbos" e "apagamentos em não verbos", conforme descrito.

Verificam-se os desempenhos na escrita de 80 alunos, cujas marcas de apagamento do rótico em posição de coda final e medial, verbos e não verbos, possuem incidência significativa no repertório linguístico deles, em especial, nos verbos em posição final, conforme se verifica nos quadros-sínteses, gráficos e exemplos que se seguem:

2 Os resultados deste capítulo fazem parte de uma pesquisa mais abrangente, ainda em andamento, que tem como objetivo construir um banco de redações de alunos de Porto Velho (RO). Esta pesquisa está registrada na Plataforma Brasil e aprovada pelo Comitê de Ética em Pesquisa com Seres Humanos (parecer 2.689.238). Esses textos constituirão um banco de dados que propiciarão diferentes investigações linguísticas, tendo como enfoque principal as análises fonéticas e fonológicas. 
Quadro 1 - Quadro geral de apagamentos em não verbos

\begin{tabular}{|c|c|c|}
\hline INFORMANTE & $\begin{array}{c}\text { APAGAMENTOS EM } \\
\text { NÃO VERBOS }\end{array}$ & FORMA CONVENCIONAL \\
\hline 13 & pecusso & percurso \\
\hline 28 & contubado & conturbado \\
\hline 55 & amo & amor \\
\hline 64 & Amulhe & a mulher \\
\hline 83 & peto & perto \\
\hline 91 & enterio & interior \\
\hline
\end{tabular}

Fonte: produzido pelos autores (2020).

Quadro 2-Quadro geral de apagamentos em verbos

\begin{tabular}{|c|c|c|c|}
\hline INFORMANTE & CONJUGAÇÃO & $\begin{array}{c}\text { APAGAMENTOS } \\
\text { EM VERBOS }\end{array}$ & $\begin{array}{c}\text { FORMA } \\
\text { CONVENCIONAL }\end{array}$ \\
\hline 03 & $1^{\mathrm{a}}(-\mathrm{ar})$ & joga & jogar \\
\hline 04 & $3^{a}(-i r)$ & ouvi & ouvir \\
\hline 04 & $1^{\mathrm{a}}(-\mathrm{ar})$ & lembra & lembrar \\
\hline 08 & $1^{\mathrm{a}}(-\mathrm{ar})$ & passa & passar \\
\hline 08 & $2^{\mathrm{a}}(\mathrm{er})$ & come & comer \\
\hline 11 & $1^{\mathrm{a}}(-\mathrm{ar})$ & assina & Assinar \\
\hline 13 & $1^{\mathrm{a}}(-\mathrm{ar})$ & ájuda & ajudar \\
\hline 13 & $2^{\mathrm{a}}(\mathrm{er})$ & vence & vencer \\
\hline 13 & $1^{\mathrm{a}}(-\mathrm{ar})$ & compra & comprar \\
\hline 13 & $1^{\mathrm{a}}(-\mathrm{ar})$ & $\mathrm{da}$ & dar \\
\hline 16 & $1^{\mathrm{a}}(-\mathrm{ar})$ & trabalha & trabalhar \\
\hline 17 & $3^{a}(-i r)$ & servi & servir \\
\hline 19 & $1^{\mathrm{a}}(-\mathrm{ar})$ & $\mathrm{da}$ & dar \\
\hline 19 & $2^{\mathrm{a}}(\mathrm{er})$ & pode & poder \\
\hline 19 & $1^{a}(-a r)$ & esta & estar \\
\hline 19 & $1^{\mathrm{a}}(-\mathrm{ar})$ & entra & entrar \\
\hline 19 & $1^{a}(-a r)$ & Recomeça & recomeçar \\
\hline 22 & $1^{\mathrm{a}}(-\mathrm{ar})$ & compra & comprar \\
\hline 22 & $1^{a}(-a r)$ & respira & respirar \\
\hline 24 & $3^{a}(-i r)$ & consegui & conseguir \\
\hline 24 & $1^{\mathrm{a}}(-\mathrm{ar})$ & foca & focar \\
\hline
\end{tabular}




\begin{tabular}{|c|c|c|c|}
\hline INFORMANTE & CONJUGAÇÃO & $\begin{array}{c}\text { APAGAMENTOS } \\
\text { EM VERBOS }\end{array}$ & $\begin{array}{c}\text { FORMA } \\
\text { CONVENCIONAL }\end{array}$ \\
\hline 24 & $3^{a}(-$ ir $)$ & servi & servir \\
\hline 25 & $1^{\mathrm{a}}(-\mathrm{ar})$ & mora & morar \\
\hline 26 & $1^{\mathrm{a}}(-\mathrm{ar})$ & fica & ficar \\
\hline 29 & $1^{\mathrm{a}}(-\mathrm{ar})$ & preocupa & preocupar \\
\hline 29 & $2^{\mathrm{a}}(-\mathrm{ar})$ & amanhece & amanhecer \\
\hline 31 & $2^{\mathrm{a}}(\mathrm{er})$ & vive & viver \\
\hline 33 & $1^{\mathrm{a}}(-\mathrm{ar})$ & mata & matar \\
\hline 35 & $3^{a}(-i r)$ & dormi & dormir \\
\hline 35 & $1^{\mathrm{a}}(-\mathrm{ar})$ & esforça & esforçar \\
\hline 36 & $1^{\mathrm{a}}(-\mathrm{ar})$ & embarca & embarcar \\
\hline 37 & $1^{\mathrm{a}}(-\mathrm{ar})$ & deixa & deixar \\
\hline 53 & $1^{\mathrm{a}}(-\mathrm{ar})$ & estuda & estudar. \\
\hline 54 & $2^{\mathrm{a}}(-\mathrm{er})$ & se & ser \\
\hline 54 & $1^{\mathrm{a}}(-\mathrm{ar})$ & trabalha & trabalhar \\
\hline 54 & $1^{a}(-a r)$ & estuda & estudar \\
\hline 54 & $1^{a}(-a r)$ & faze & fazer \\
\hline 54 & $2^{\mathrm{a}}(-\mathrm{er})$ & ve & ver \\
\hline 54 & $1^{a}(-a r)$ & comesa & começar \\
\hline 54 & $1^{\mathrm{a}}(-\mathrm{ar})$ & espera & esperar \\
\hline 54 & $1^{a}(-a r)$ & acaba & acabar \\
\hline 54 & $1^{\mathrm{a}}(-\mathrm{ar})$ & chega & chegar \\
\hline 54 & $3^{\mathrm{a}}(-\mathrm{ir})$ & $\mathrm{i}$ & ir \\
\hline 54 & $1^{\mathrm{a}}(-\mathrm{ar})$ & toma & tomar \\
\hline 54 & $2^{\mathrm{a}}(-\mathrm{er})$ & bate & bater \\
\hline 55 & $2^{\mathrm{a}}(-\mathrm{er})$ & se & ser \\
\hline 55 & $2^{\mathrm{a}}(-\mathrm{er})$ & te & ter \\
\hline 55 & $1^{a}(-a r)$ & mehora & melhorar \\
\hline 56 & $1^{\mathrm{a}}(-\mathrm{ar})$ & comta, & Contar \\
\hline 56 & $2^{\mathrm{a}}(-\mathrm{er})$ & vende & vender \\
\hline 56 & $1^{\mathrm{a}}(-\mathrm{ar})$ & trafica & traficar \\
\hline 56 & $1^{\mathrm{a}}(-\mathrm{ar})$ & paga & pagar \\
\hline 56 & $1^{\mathrm{a}}(-\mathrm{ar})$ & tira & tirar \\
\hline 56 & $1^{a}(-a r)$ & té mina & terminar \\
\hline 57 & $2^{\mathrm{a}}(-\mathrm{er})$ & acontece & acontecer \\
\hline
\end{tabular}




\begin{tabular}{|c|c|c|c|}
\hline INFORMANTE & CONJUGAÇÃO & $\begin{array}{c}\text { APAGAMENTOS } \\
\text { EM VERBOS }\end{array}$ & $\begin{array}{c}\text { FORMA } \\
\text { CONVENCIONAL }\end{array}$ \\
\hline 57 & $2^{\mathrm{a}}(-\mathrm{er})$ & conhece & conhecer \\
\hline 57 & $1^{\mathrm{a}}(-\mathrm{ar})$ & chega & chegar \\
\hline 57 & $1^{a}(-a r)$ & fala & falar \\
\hline 57 & $1^{\mathrm{a}}(-\mathrm{ar})$ & falece & falecer \\
\hline 57 & $1^{\mathrm{a}}(-\mathrm{ar})$ & avisa & avisar \\
\hline 57 & $1^{\mathrm{a}}(-\mathrm{ar})$ & sabe/sabe & saber \\
\hline 57 & $1^{\mathrm{a}}(-\mathrm{ar})$ & quere & querer \\
\hline 57 & $1^{\mathrm{a}}(-\mathrm{ar})$ & cinviga & vingar \\
\hline 57 & $1^{\mathrm{a}}(-\mathrm{ar})$ & viaja & viajar \\
\hline 57 & $1^{\mathrm{a}}(-\mathrm{ar})$ & conhece & conhecer \\
\hline 58 & $1^{\mathrm{a}}(-\mathrm{ar})$ & mora & morar. \\
\hline 59 & $1^{\mathrm{a}}(-\mathrm{ar})$ & pesca & pescar \\
\hline 59 & $1^{\mathrm{a}}(-\mathrm{ar})$ & caça & caçar \\
\hline 59 & $1^{\mathrm{a}}(-\mathrm{ar})$ & marta. & matar \\
\hline 62 & $1^{\mathrm{a}}(-\mathrm{ar})$ & tranca & trancar, morder \\
\hline 62 & $1^{\mathrm{a}}(-\mathrm{ar})$ & morde & morder \\
\hline 64 & $2^{\mathrm{a}}(-\mathrm{er})$ & morre & morrer \\
\hline 65 & $1^{\mathrm{a}}(-\mathrm{ar})$ & fala & falar \\
\hline 67 & $1^{\mathrm{a}}(-\mathrm{ar})$ & para & parar \\
\hline 70 & $1^{\mathrm{a}}(-\mathrm{ar})$ & mora & morar \\
\hline 70 & $1^{a}(-a r)$ & acompanha & acompanhar \\
\hline 72 & $1^{a}(-a r)$ & chora & chorar \\
\hline 72 & $1^{a}(-a r)$ & volta & voltar \\
\hline 76 & $2^{a}(-e r)$ & entende & entender \\
\hline 76 & $1^{\mathrm{a}}(-\mathrm{ar})$ & Abençoa & abençoar \\
\hline 80 & $1^{a}(-a r)$ & deixa & deixar \\
\hline 80 & $2^{\mathrm{a}}(-\mathrm{er})$ & que & quer \\
\hline 80 & $2^{\mathrm{a}}(-\mathrm{er})$ & conhece & conhecer \\
\hline 80 & $3^{a}(-i r)$ & curti & curtir \\
\hline 82 & $1^{\mathrm{a}}(-\mathrm{ar})$ & Passa & Passar \\
\hline 82 & $1^{\mathrm{a}}(-\mathrm{ar})$ & anda & andar \\
\hline 82 & $1^{\mathrm{a}}(-\mathrm{ar})$ & joga & jogar \\
\hline 82 & $1^{a}(-a r)$ & avísa & avisar \\
\hline 82 & $2^{\mathrm{a}}(-\mathrm{er})$ & esquece & esquecer. \\
\hline
\end{tabular}




\begin{tabular}{|c|c|c|c|}
\hline INFORMANTE & CONJUGAÇÃO & $\begin{array}{c}\text { APAGAMENTOS } \\
\text { EM VERBOS }\end{array}$ & $\begin{array}{c}\text { FORMA } \\
\text { CONVENCIONAL }\end{array}$ \\
\hline 87 & $1^{\text {a }}(-a r)$ & joga & jogar \\
\hline 90 & $1^{\text {a }}(-$ ar $)$ & compra & comprar \\
\hline 91 & $1^{\text {a }}(-$ ar $)$ & trabalha & trabalhar \\
\hline 91 & $1^{\text {a }}(-a r)$ & volta & voltar \\
\hline 91 & $1^{\text {a }}(-a r)$ & pesca & pescar \\
\hline
\end{tabular}

Fonte: produzido pelos autores (2020).

Quadro 3 - Número total de apagamento do rótico em sílaba interna

\begin{tabular}{|c|c|}
\hline $\begin{array}{c}\text { APAGAMENTOS EM SÍLABA } \\
\text { INTERNA(VERBOS) }\end{array}$ & $\begin{array}{c}\text { APAGAMENTOS EM SÍLABA } \\
\text { INTERNA(NÃO VERBOS) }\end{array}$ \\
\hline 06 & 03 \\
\hline
\end{tabular}

Fonte: produzido pelos autores (2020).

Quadro 4 - Número total de apagamento do rótico no final de palavras

\begin{tabular}{|c|c|}
\hline $\begin{array}{c}\text { APAGAMENTOS NO FINAL } \\
\text { DE PALAVRAS (VERBOS) }\end{array}$ & $\begin{array}{c}\text { APAGAMENTOS NO FINAL DE } \\
\text { PALAVRAS (NÃO VERBOS) }\end{array}$ \\
\hline 95 & 03 \\
\hline
\end{tabular}

Fonte: produzido pelos autores (2020).

Nota-se que o apagamento do rótico no final de palavras é o mais recorrente. Sobre esse assunto, Callou, Serra e Cunha (2015, p. 200) defendem a hipótese que "[...] a presença do R, em coda silábica final, constituiria, no caso, uma marca morfológica de caráter redundante, já que o infinitivo e o subjuntivo futuro são marcados também pelo acento lexical na última sílaba”. 
Gráfico 1 - Distribuição entre verbos e não verbos

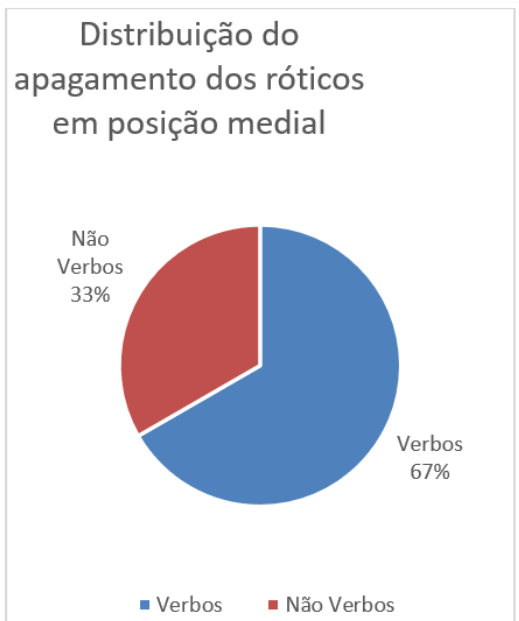

Fonte: produzido pelos autores (2020).

Gráfico 2 - Distribuição dos róticos em posição de coda final

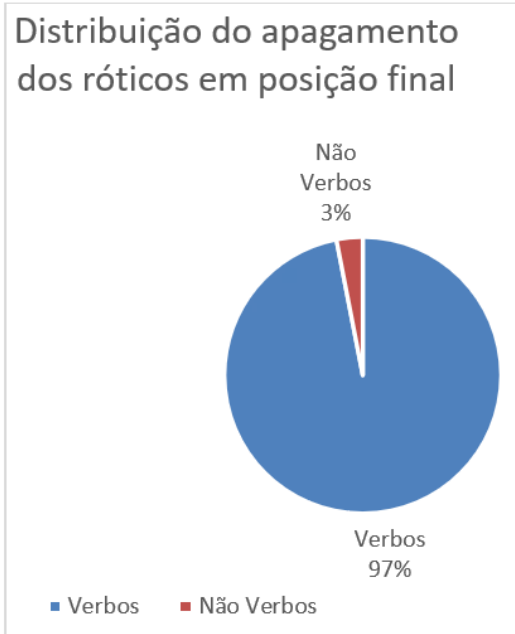

Fonte: produzido pelos autores (2020).

A partir dos quadros e gráficos, verifica-se que o fenômeno de apagamento do rótico em não verbos, seja na posição de coda medial, seja na final, foram encontradas poucas evidências (total de seis). O excerto abaixo exemplifica uma das situações encontradas: 


\section{Exemplo 1}

“[...] vamos, não tenhe Problema. Seguimos a viajer ele convesando comingo falou Pouco dele então nos convesado ele me falou uma coisa que eu fiquei[...] um colegar que sair 5 horas da manhã ProTrabalhar e sair 4 horas da Tarde um Pecusso." (Informante n. ${ }^{\circ}$ 13, Escola D).

Figura 1 - Trecho redação - Informante n. 13 - Escola D

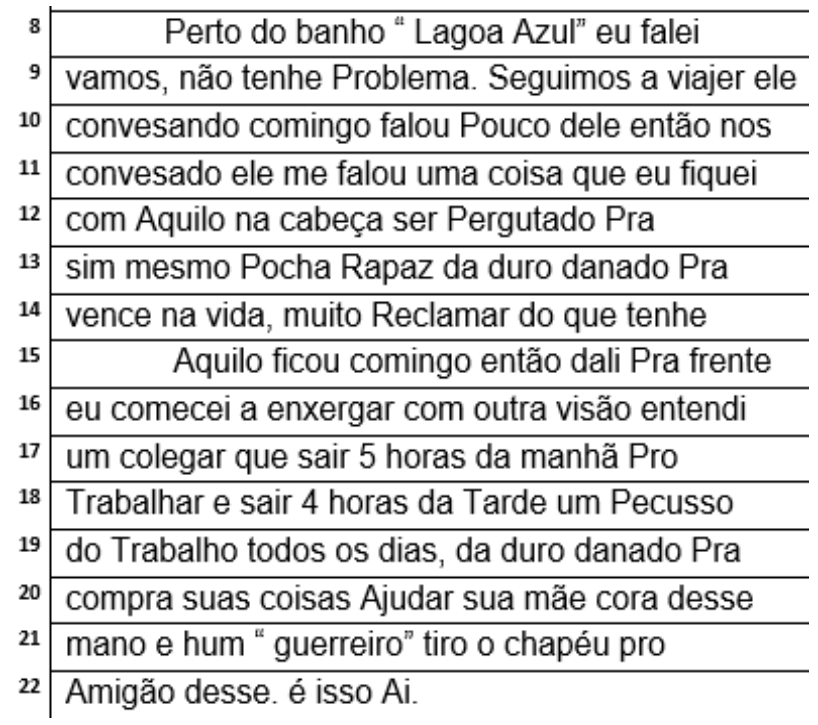

Fonte: acervo dos pesquisadores (2020).

No entanto, conforme demarcado pelo levantamento apresentado no quadro 2 , a incidência do fenômeno de apagamento do rótico tem maior representatividade nos verbos, sendo de $67 \%$ em posição de coda medial e de $97 \%$ em posição final. Esses dados ratificam a teoria de que o apagamento do //R em posição final em verbos nas produções textuais é mais recorrente.

Observa-se, ainda, a partir do quadro 2, que a ocorrência do fenômeno em análise incide, quase que exclusivamente, em verbos no infinitivo e, para mais além, naqueles decorrentes da de $1^{\mathrm{a}}$ conjugação (terminados em -ar), conforme se constata na síntese dos quadros 5, 6 e 7. 
Quadro 5 - Quantidade geral de verbos no infinitivo (escola A)

\begin{tabular}{|l|c|}
\hline \multicolumn{1}{|c|}{ Verbos } & Com apagamento do $\mathbf{R}$ \\
\hline $1^{\text {a }}$ conjugação (-ar) & 47 \\
\hline 2 $^{\text {a } \text { conjugação (-er) }}$ & 13 \\
\hline $3^{\text {a } \text { conjugação }(-i r)}$ & 2 \\
\hline Total & $\mathbf{6 2}$ \\
\hline
\end{tabular}

Fonte: produzido pelos autores (2020).

Quadro 6-Quantidade geral de verbos no infinitivo (escola D)

\begin{tabular}{|l|c|}
\hline \multicolumn{1}{|c|}{ Verbos } & Com apagamento do $\mathbf{R}$ \\
\hline $1^{\text {a }}$ conjugação (-ar) & 22 \\
\hline $2^{\text {a }}$ conjugação (-er) & 05 \\
\hline $3^{\text {a } \text { conjugação }(-i r)}$ & 05 \\
\hline Total & $\mathbf{3 2}$ \\
\hline
\end{tabular}

Fonte: produzido pelos autores (2020).

Quadro 7 - Quantidade geral de verbos no infinitivo (escolas A e D):

\begin{tabular}{|l|c|}
\hline \multicolumn{1}{|c|}{ Verbos } & Com apagamento do R \\
\hline 1 $^{\text {a } \text { conjugação }(-a r)}$ & 132 \\
\hline 2 $^{\text {a }}$ conjugação $(-e r)$ & 18 \\
\hline 3 $^{\text {a } \text { conjugação }(-i r)}$ & 7 \\
\hline Total & $\mathbf{1 5 7}$ \\
\hline
\end{tabular}

Fonte: produzido pelos autores (2020).

$\mathrm{Da}$ análise, verificou-se que, apesar da incidência do apagamento do $\mathrm{R}$ em infinitivo verbal em todas as conjugações, as da primeira conjugação são as mais frequentes, como se verifica nos exemplos a seguir:

\section{Exemplo 2}

“[...] Sou muito grata a Deus por essa benção e por pode esta, tendo uma nova oportunidade novamente, eu agora com 33 anos, quero apenas Concluír o ensino médio e poder futuramente entra numa faculdade.”. (Informante n. ${ }^{\circ} 19$, Escola D). 
Figura 2 - Trecho redação - Informante n. ${ }^{\circ} 19$ - Escola D

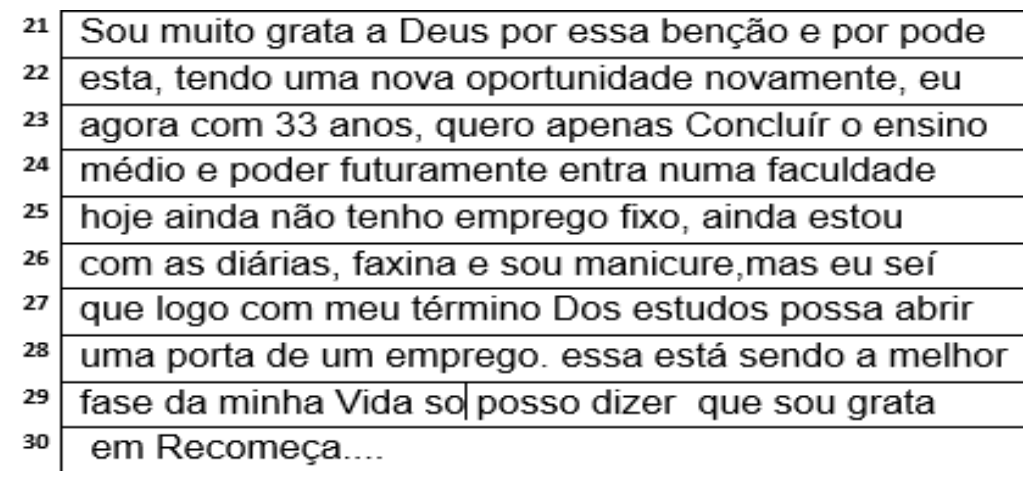

Fonte: acervo dos pesquisadores (2020).

\section{Exemplo 3}

"[...] acompanhou na gravides toda e quando ficamos sabendo que era uma menina na mesma hora formos compra algumas coisas ja para ela.". (Informante n. ${ }^{\circ} 2$, Escola D).

Figura 3 - Trecho redação - Informante n. 22 - Escola D

\begin{tabular}{|c|c|}
\hline & Na minha adolecência eu engravidei com \\
\hline & 17 anos, foi uma mistura de emoções que eu \\
\hline & senti. Eu é meu namorado ser juntamos e \\
\hline & com minha gravides minha família mim \\
\hline & acompanhou na gravides toda e quando ficamos \\
\hline & sabendo que era uma menina na mesma hora \\
\hline & formos compra algumas coisas ja para ela. \\
\hline & Eu enjoei muito é quando eu fui para \\
\hline & ter minha pressão começou a ficar alta \\
\hline & e fui encaminhada para para o hospital, é fiquei \\
\hline & lá. Comecei te uma doença que se chama \\
\hline & eclanpise, eu e minha filha passamos \\
\hline & mal eu na hora do parto convunçei e minha \\
\hline & filha tever|que ser reanimada e ir para a \\
\hline & UTI respira pelos aparelhos. É ela ficou com \\
\hline & saúde e tever alta para ir para casa. \\
\hline
\end{tabular}

Fonte: acervo dos pesquisadores (2020). 


\section{Exemplo 4}

"era o que ela dizia, que tinha que tranca meu filho para não morde as outras crianças[...].” (Informante n. ${ }^{\circ}$ 62, Escola A).

\begin{tabular}{|c|c|}
\hline & Falar pra mim leva ele ão médico por que ela \\
\hline & não era bem da cabeça não. era o que ela \\
\hline & dizia, que tinha que tranca meu filho para \\
\hline & não morde as outras crianças ( outros sobrinhos) \\
\hline & Com 6 meses gente,, 6 meses meu filho tinha. Então \\
\hline & logo depois ela engravidou tambem ( minha irma) \\
\hline & o filho dela ( meu sobrinho) narceu com deficiência. \\
\hline & e hoje sofre muito com ele, com viagem, consulta \\
\hline & remédios, etc. Não que tenha desejado o mal pra \\
\hline & minha irma não... mais tem um proverbios que \\
\hline 22 & diz: Aqui se faz, aqui se paga. Eu já perdoei \\
\hline 23 & ela mais jamais esqueço, pois foi uma época \\
\hline 24 & inesquecível. \\
\hline
\end{tabular}

Fonte: acervo dos pesquisadores (2020).

Sobre a incidência do rótico nos verbos, Oliveira e Prado (2020,p. 81) concluem que:

Isso pode ocorrer visto que o " $\mathrm{r}$ ", como marcação do infinitivo, sofre apagamento de forma praticamente categórica na fala espontânea dos brasileiros, o que o denota como um traço gradual e generalizado, enquanto, nas demais classes de palavras, seu apagamento é menos frequente.

Em estudo semelhante realizado em escolas da cidade de Porto Velho (RO), Oliveira e Prado (2020) encontraram, igualmente, maior percentual de apagamento do rótico nos verbos infinitivos de $1^{\mathrm{a}}$ conjugação $(25,91 \%)$, seguido das $2^{\text {a }}(13,69 \%)$ e $3^{\text {a }}(9,85 \%)$, evidenciando, uma vez mais que o fenômeno em estudo não só se refere à uma presença constante nas escolas daquela localidade, como possui maior incidência em verbos do infinitivo. 
Para Callou, Serra e Cunha (2015, p. 201), "a presença de uma consoante de articulação aproximada à do rótico favorece processos assimilatórios que podem levar ao cancelamento de um dos segmentos”, de forma que tal cancelamento e a dimensão do vocábulo têm gerado importantes análises. As autoras ainda argumentam que "[...] a partir da hipótese da saliência fônica, espera-se que, em vocábulos com maior número de sílabas haja maior probabilidade de apagamento do $/ \mathrm{R} /$, pois o segmento seria, aí, menos saliente" (CALLOU; SERRA; CUNHA, 2015, p. 201).

Ao fazer uma comparação com os dados do estudo de Oliveira e Prado (2020), que analisaram o apagamento do / R/ no final de infinitivos verbais em redações de alunos do $6^{\circ}$ ano do ensino fundamental de escolas de Porto Velho, é possível constatar que as produções textuais dos alunos do ensino médio/ EJA possuem desvios similares. Nas conclusões daquele trabalho registrou-se que: "o apagamento do -r nas formas verbais infinitivas é uma realidade incontestável na escrita de pessoas de ambos os sexos, independente de idade e de escolaridade" (Oliveira; Prado, 2020, p. 102).

Assim, a partir do objetivo deste estudo, verificou-se o registro significativo do fenômeno de apagamento do rótico em coda final na escrita desses alunos, apontando um possível processo de enfraquecimento da presença do $/ \mathrm{R} /$ nesta posição também na fala. A respeito desse enfraquecimento, Callou, Leite e Moraes (1996, p. 284) declaram que "o processo de enfraquecimento é geralmente tratado em termos de uma escala de força estabelecida com base em graus de abertura do trato vocal, que provocariam um decréscimo gradual da resistência à saída da corrente de ar."

Foi verificado, ainda, que o apagamento apresentou maior tendência em posição final dos verbos, mostrando, nesse caso, que a separação de ordem de classificação morfológica entre verbos e não verbos se fez significativa. Os resultados confirmaram a hipótese de que os alunos transpõem a fala para a escrita, bem como ratificam o entendimento de que em que pese a diversidade de sujeitos que compõem o grupo de estudantes da modalidade EJA, a maioria ainda desconhece as diferenças entre língua falada e escrita e as suas variações, isso porque as falhas decorrentes dessa transpo- 
sição - da fala para a escrita - se mostram comuns, uma vez que a variante padrão - da norma culta - está muito distante desse educandos, com isso, o que ele ouve, repete na fala e transpõe na escrita.

\section{Considerações finais}

A partir da análise das ocorrências de apagamento do $/ \mathrm{R} /$ em posição de coda medial e final de verbos e não verbos que integraram os 80 textos recolhidos, verificou-se a incidência de 111 casos em verbos e 6 em não verbos, apontando, assim, a necessidade de maior investigação dos aspectos que levam a tal fenômeno, seja a partir do transporte das marcas de oralidade para a escrita ou, ainda, a partir de características linguísticas e extralinguísticas.

De forma geral, os resultados indicam que os aspectos regionais e socioculturais dos alunos que integraram a pesquisa apresentam elementos de variações linguísticas do português, que apagam o $/ \mathrm{R} /$, principalmente, em final de verbos.

Assim, o processo de análise e compreensão quanto ao fenômeno de apagamento do rótico - em especial, na posição final em verbos - a partir da produção textual de estudantes da Educação de Jovens e Adultos e dos aspectos que influenciam diretamente nessa ocorrência, permitiu a estes pesquisadores identificar e refletir, de forma ampla, sobre a relação entre a oralidade e escrita, importante área dentro da análise linguística do português brasileiro.

Apreender as convenções e seus desvios dentro da complexa ortografia da língua portuguesa se mostra um desafio tanto para o docente como para o seu alunado, pois se refere a um processo de ensino e aprendizagem contínuo que não se esgota dentro da sala de aula, restando evidenciado que necessário se faz conhecer não só as regras da língua padrão como de onde advêm os desvios de fala, geralmente transportados para a escrita, conforme verificado nos desvios dos textos analisados, com a ocorrência significativa do apagamento do rótico no final de verbos.

A partir das análises efetuadas, observou-se que o apagamento do rótico é mais recorrente em final de infinitivos verbais. Sobre esse fenômeno, Bortoni-Ricardo (2006, p. 269) afirma que: 
[...] no português brasileiro, há uma forte tendência para suprimirmos o $/ \mathrm{r} /$ final nos infinitivos verbais(...) tendemos a suprimi-lo mais frequentemente nos infinitivos e nas formas verbais do futuro do subjuntivo e em palavras com mais de uma sílaba.

Oliveira e Prado (2020, p. 82), no trabalho desenvolvido a partir da análise de textos de alunos do ensino fundamental em Porto Velho (RO), sobre o apagamento do rótico em final de infinitivos verbais, afirmam que:

[...] compreender o fenômeno de apagamento do $/ \mathrm{R} / \mathrm{em}$ fim de verbos do infinitivo em produções textuais de alunos e seus fatores condicionantes auxilia na compreensão da relação mais ampla entre a oralidade e escrita e constitui um importante exercício de reflexão e análise linguística.

Nesse sentido, uma vez que tais variações se façam reconhecidas, novas metodologias podem ser implementadas pelo professor para trabalhar nas questões do apagamento do rótico na escrita dos alunos. $\mathrm{O}$ desenvolvimento de estudos, como do fenômeno de apagamento do rótico, mostrou-se adequado e relevante também para vislumbrar outros aprofundamentos, por exemplo, neste caso, o alcance de uma melhor compreensão sobre a relação dos desvios ortográficos nas produções textuais e os índices de fracasso e evasão escolar dos alunos da Educação de Jovens e Adultos.

\section{Referências}

ARROYO, M. G. A Educação de Jovens e Adultos em tempos de exclusão. In: Construção coletiva: Contribuições à Educação de Jovens e Adultos. Brasília, DF: UNESCO, MEC, RAAAB, 2005.

AZEREDO, J. C. de. Gramática Houaiss da Língua Portuguesa. São Paulo, SP: Publifolha, 2014.

BISOL, L. A neutralização das átonas. Revista Letras, Curitiba, PR, n. 61, esp., p. 273-283, 2003. 
BISOL, L.; CÂMARA JR., J. M. e a palavra prosódica. DELTA, São Paulo, SP, v. 20, n. ${ }^{\circ}$ especial, p. 59-70, 2004.

BISOL, L. Harmonização vocálica: efeito parcial e total. Organon, Porto Alegre, RS, v. 28, n. 54, p. 49-61, jan.-jun. 2013.

BORTONI-RICARDO, S. M. O estatuto do erro na língua oral e na língua escrita. In: GORSKI, Edair Maria; COELHO, Izete Lehmkuhl.(orgs.). Sociolinguística e ensino: contribuições para a formação do professor de língua. Florianópolis, SC: UFSC, 2006, p. 267-276.

BORTONI-RICARDO, S. M. Educação em língua materna: a sociolinguística na sala de aula. São Paulo, SP: Parábola Editorial, 2004.

BOTASSINI, J. O. M. A variação no uso dos róticos em Porto Alegre. Estudos Linguísticos, São Paulo, SP, v. 40, n. 2, p. 1060-1072, maio/ago. 2011.

BRASIL. Lei 9.496/1996. Lei de Diretrizes e Bases da Educação Nacional (LDB). Brasília, DF, 1996.

BRASIL. Ministério da Educação. Conselho Nacional de Educação. Parecer CNE/CEB n. ${ }^{\circ}$ 11/2000. Dispõe sobre as Diretrizes Curriculares Nacionais para a Educação de Jovens e Adultos. Brasília, DF, 2000.

BRITO, J. A. M. de. As práticas de letramento no contexto da EJA. 2011. 120 p. Dissertação (Mestrado em Educação) - Programa de Pós-Graduação em Educação, Universidade Federal do Amazonas - UFAM, Manaus, AM, 2011.

CAGLIARI, L. C. Alfabetização e linguística. 10. ed. São Paulo, SP: Editora Scipione, 2008.

CALLOU, D. Variação e distribuição da vibrante na fala culta do Rio de Janeiro. Rio de Janeiro, RJ: UFRJ/PROED, 1987. 
CALLOU, D.; LEITE, Y. Iniciação à fonética e à fonologia. 11. ed. Rio de Janeiro, RJ: Jorge Zahar Editora, 2009.

CÂMARA JR., J. M. Estrutura da língua portuguesa. Petrópolis, RJ: Editora Vozes, 1970

CARDOSO, D. P. G268f Fonologia da Língua Portuguesa. São Cristóvão, SE: Universidade Federal de Sergipe, CESAD, 2009.

COSTA.G. B da. O apagamento do rótico em coda silábica na escrita de estudantes catuenses. In: Letra Magna Revista Eletrônica de Divulgação Científica em Língua Portuguesa, Linguística e Literatura, Ano 05, n. 10 - $1^{\text {o }}$ Semestre de 2009.

FRAGO, A. V. Alfabetização na sociedade e na história: vozes, palavras e textos. Porto Alegre, RS: ArtMed Editora, 1993.

GALVÃO, A. M. de O.; SOARES, L. J. G. História da Alfabetização de Adultos no Brasil. In: ALBUQUERQUE, E. B. C. de; LEAL, T. F. (Orgs.). Alfabetização de Jovens e Adultos em uma perspectiva do letramento. Belo Horizonte, MG: Autêntica Editora, 2006.

GIL, A. C. Métodos e técnicas de pesquisa social. 7. ed. São Paulo, SP: Editora Atlas S.A., 2019.

HORA, D.; MONARETTO, V. Enfraquecimento e apagamento dos róticos. In: HORA, D.; COLLISCHONN, G. (org.). Teoria Linguística: fonologia e outros temas. João Pessoa, PB: EDUFPB, 2003, p. 114-143.

HOUAISS, A. O português no Brasil. Rio de Janeiro, RJ: UNIBRADE/ UNESCO, 1985.

IBGE. Instituto Brasileiro de Geografia e Estatística. Pesquisa Nacional por Amostra de Domicílios Contínua de 2018. PNAD 2018. Disponível em: ht- 
tps://educa.ibge.gov.br/jovens /conheca-o-brasil/populacao/18317-educacao. html. Acesso em: 20 abr. 2020.

INEP. Instituto Nacional de Estudos e Pesquisas Educacionais Anísio Teixeira. Revista Brasileira de Estudos Pedagógicos, Brasília, DF, v. 97, n. 247, set./dez. 2016. Disponível em: http://portal.inep.gov.br/documents/186968/489316/ REVISTA+BRASILEIRA+DE+ $\quad$ ESTUDOS+PEDAG\%C3\%93GICOS+\%28RBEP\%29+-+NUM+247/7cc417a5-b9c3-4f51-88a6-a562ad74e08c?version=1.0. Acesso em: 6 ago. 2020.

LEITE, C. M. B. Atitudes linguísticas: a variante retroflexa em foco. 2004. 149f. Dissertação (Mestrado em Linguística) - Instituto de Estudos da Linguagem, Universidade Estadual de Campinas. Campinas, SP, 2004.

MARCUSCHI, L. A. Da fala para a escrita: atividades de retextualização. 9. ed. São Paulo, SP: Editora Cortez, 2008.

OLIVEIRA, M. A. de. Phonological variation and change in Brazilian Portuguese: the case of the liquids. Tese de Doutorado. University of Pennsylvania. 1983. Dissertations available from ProQuest. AAI8406656. Disponível em: https://repository.upenn.edu/dissertations /AAI8406656. Acesso em: 6 ago. 2020.

OLIVEIRA, S. E. C.; PRADO, N. C. O apagamento do /R/ em final de infinitivos verbais em redações de alunos do Ensino Fundamental II. In: PRADO N. C.; O’NEILL.P; MASSINI-CAGLIARI.G. Variação, mudança e preconceito linguístico: fenômenos da língua portuguesa atual e antiga. Revista Falange Miúda, v. 5 n. 2, 2020.

SILVA, V. I. da. A fonologia e suas possíveis contribuições para a alfabetização na Educação de Jovens e Adultos. 110f. 2016. Dissertação (Mestrado em Linguística). Programa de Pós-graduação em Letras. Universidade Federal de Pernambuco. Recife, PE, 2016. 
SILVA NETO, S. Introdução ao estudo da língua portuguesa no Brasil. 2. ed. Rio de Janeiro, RJ: INL/MEC, 1963 [1950].

SOARES, M. Letramento: um tema em três gêneros. 2. ed. Belo Horizonte, MG: Autêntica Editora, 2006.

SOARES, M. Alfabetização e letramento. 6. ed. São Paulo, SP: Editora Contexto, 2010.

SCHWNDT, L. C.; QUADROS, E. S.; TOLEDO, E. E.; GONZALEZ, C. A. A influência da variável escolaridade em fenômenos fonológicos variáveis: efeitos retroalimentadores da escrita. ReVEL Revista Virtual de Estudos da Linguagem. v. 5, n. 9, ago. 2007. ISSN 1678-8931. Disponível em: http:// www.revel.inf.br/pt. Acesso em: 6 ago. 2020.

TARALLO, F. A pesquisa sociolinguística. 6. ed. São Paulo, SP: Editora Ática. 2001.

TFOUNI, L. V. Letramento e alfabetização. 2. ed. São Paulo, SP: Editora Cortez, 1997. (Questões da nossa época; v. 47). 


\section{INVENTÁRIO SONORO DA LÍNGUA AIKANÃ: REVISÃO DO SISTEMA CONSONANTAL}

Patrícia Goulart Tondineli

\section{Introdução}

A escolha da língua Aikanã para objeto da análise aqui proposta se justifica pelo sério risco de extinção a curto prazo. Tendo como base os graus de perigo, tanto os propostos pela UNESCO (2010) quanto os expostos por Eberhard (2013), a língua Aikanã é classificada como definitivamente ameaçada. Para agravar tal quadro, verifica-se que o povo Aikanã se encontra em processo de aculturação, com perda de sua respectiva identidade linguística mesmo que a Terra Indígena Tubarão Latundê, onde vivem, possua escola, não há muitas situações sociais em que a língua nativa seja usada, pois, na maioria dos contatos entre eles, falam efetivamente o português.

A língua Aikanã, considerada isolada, foi já descrita por alguns linguistas, como Vasconcelos (2002), Silva (2012), Storto e Demolin (2012); Voort (2013); Storto (2019) e Tondineli (2020). Apesar disso, e provavelmente por causa de tais descrições, a necessidade de pesquisar o sistema fonético-fonológico do Aikanã é premente, tendo em vista que ele é o ponto de partida para que possamos difundir a língua em si.

No caso da língua Aikanã, o que se pôde comprovar em Tondineli (2020) foi ausência de consenso quanto ao seu sistema fonético-fonológico vocálico. Tal conclusão é o que observamos incialmente também em relação ao inventário consonantal, foco deste estudo. Consequentemente, a situação de isolamento genético da língua Aikanã e de falta de consenso na documentação científica justifica a relevância e a prioridade do trabalho aqui proposto.

Desse modo, pesquisar e descrever a língua Aikanã trará resultados ricos e importantes para a sociedade, porque os indivíduos ampliarão seus conhecimentos a respeitos de línguas e culturas indígenas, reconstruindo-se a pré- 
-história linguística e determinando-se a natureza, o leque e os limites de suas possibilidades linguísticas, tanto em termos de estrutura quanto em termos de comportamento comunicativo ou de expressão e criatividade poética. Tal ação beneficia, portanto, a comunidade indígena investigada e a sociedade em geral, por objetivar o desvelamento de aspectos que compõem as línguas indígenas e, por consequência, a historiografia do povo brasileiro. Além disso, beneficia os estudos sobre as línguas originárias, fortalecendo a pesquisa no âmbito acadêmico, seja na graduação, seja na pós-graduação, ampliando o leque dos conhecimentos científicos e incentivando novas propostas de investigação das línguas indígenas de Rondônia e do Brasil, promovendo intercâmbios e formando redes de pesquisa cada vez mais amplas e sólidas.

\section{A língua Aikanã}

$\mathrm{Na}$ região Amazônica, o panorama linguístico caracteriza-se por três famílias linguísticas predominantes (Aruák, Karíb e Tupi-Guarani), “amplamente distribuídas no espaço geográfico” (Rodrigues, 2000, p. 17), além de diversas famílias menores e de línguas isoladas. Entre estas, encontra-se a língua indígena Aikanã, na região conhecida, linguisticamente, como Guaporé-Mamoré.

Os Aikanã vivem na Terra Indígena Tubarão Latundê (para a qual foram transferidos na década de 1970), no município de Chupinguaia, em Rondônia, juntamente com os povos Nambikwara, Nambikwara Sabanê, Nambikwara Latundê e Kwazá (Ricardo; Ricardo, 2017, p. 576).

A mais antiga referência aos Aikanã foi feita por Becker-Donner, em que são chamados de "Masaca ou Aikana”. Conforme registros, também foram nomeados "Huari”, pelo etnógrafo E. Nordenskiöld, "primeiro [...] pesquisador a registrar uma lista de palavras da língua dos Aikanã” (Souza et al., 2015, p. 70). Historicamente,

Em 1916, o Marcehal Cândido Mariano Rondon os conheceu sob o nome de Malotundú, nome dado pelos Nambikwara, os quais afirmam que os Aikanã sempre viveram perto do Rio Machado, das cachoeiras do rio Pimenta Bueno e do rio Tanaru. Contam também que, quando um 
indígena chamado Massaká era capitão, o povo ficou conhecido como Massaká (nome confirmado nos escritos de Snethage em 1974). (Souza et al., 2015, p. 70).

Segundo Censo Populacional (Rondônia, 2017), temos 74 habitantes na Aldeia Gleba e 219 na Aldeia Rio do Ouro que se intitulam Aikanã. Afora estes 293 indígenas residentes em Tubarão Latundê, há registros dos Aikanã nas Terras Indígenas Kwazá do Rio São Pedro, Rio Branco e Rio Guaporê, todas em Rondônia (Ricardo; Ricardo, 2017, p. 575-576), além daqueles que moram em cidades como "Vilhena, Porto Velho,Ji-Paraná e Guajará-Mirim” (Souza et al., 2015, p. 70).

De acordo com Tondineli (2020a), a língua Aikanã é classificada na literatura como aglutinante, hipótese que necessita de reflexões. Para a autora, pela sua complexidade, a língua Aikanã seria mais bem classificada como língua de estrutura ativa, tendo em vista, por exemplo, o morferma -na, que "pode indicar mudança de sujeito, negação ou ser marca do modo interrogativo", fato contrário à premissa de línguas aglutinantes, que "pressupõe que expressem uma categoria semântico-funcional, sendo rigorosamente mantida uma correspondência biunívoca entre forma e conteúdo” (Tondineli, 2020a).

Com ordem SOV como preferencial, a língua Aikanã possui três classes principais de palavras: verbos, substantivos e advérbios. Já as sílabas, como expõe Voort (2013, p. 362), possuem, em sua maior parte, a seguinte estrutura: CGVG, sendo as consoantes $(\mathrm{C})$ e os glides $(\mathrm{G})$ opcionais.

No seu inventário sonoro, a língua Aikanã apresenta "um sistema vocálico composto de 9 vogais orais - /i, y, e, $\varepsilon, \mathrm{i}, \mathrm{u}, \mathrm{a}, \mathrm{u}, \mathrm{o} /$ " (Tondineli, 2020, p. 916), 4 vogais nasais (Vasconcelos, 2002, p. 09) e de 10 a 16 consoantes (Vasconcelos, 2002; Silva, 2012; Storto; Demolin, 2012; Voort, 2013; Storto, 2019).

É sobre o último inventário, o consonantal, que nos debruçamos neste estudo, com o fim de melhor delinear o sistema de consoantes da língua Aikanã. Esclarecemos, ainda, que não é intento deste exame de fornecer uma análise exaustiva dos processos fonético-fonológicos da língua Aikanã; assim sendo, a nossa descrição fonético-fonológica restringe-se a parâmetros articulatórios, não sendo discutidos os aspectos suprassegmentais e prosódicos. 


\section{Sistema consonantal}

Ladefoged (2012) enumera 600 consoantes entre as línguas do mundo, sendo as oclusivas desvozeadas /p/,/t/ e / $/$ / as mais comuns, presentes em 98\% das línguas. Afirma ainda o autor que "cada língua conhecida possui sons semelhantes a dois desses três 1 ", /p, t. k/, e que as oclusivas, em algumas línguas, como a Quechua 2 , possuem o som /q/, "em que a parte de trás da língua toca o céu da boca um pouco mais para trás, mais perto da úvula" (Ladefoged; Disner, 2012, s/p).

Em relação às consoantes fricativas, Ladefoged (2012) aponta que /f/ e /v/ são as mais comuns. Outras línguas, entretanto, como a Ewe, falada em Gana, produzem, além de /f/ e /v/, as fricativas bilabiais $/ \phi /$ e $/ \beta /$.

Quanto aos sons /t/, /d/ e /n/, para Ladefoged (2012), podem ser dentários, alveolares ou pós-alveolares: "Esta é uma ampla gama de possibilidades, e, às vezes, [...] é necessário distinguir diferentes tipos de cada um desses sons." (Ladefoged, 2012, s/p). Afirma ainda que quase todas as línguas possuem a oclusiva velar / $/ \mathrm{k}$, e a maior parte das línguas do mundo possuem /g/ (Ladefoged, 2012, s/p).

Sobre as nasais, têm-se $/ \mathrm{m} / \mathrm{e} / \mathrm{n} /$ como as mais comuns, embora $/ \mathrm{y} /$ seja também bastante utilizada nas línguas do mundo; há ainda "algumas

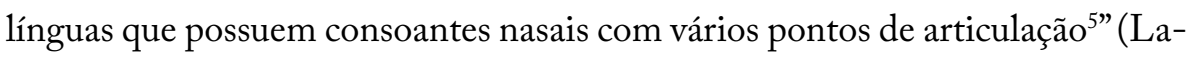
defoged, 2012, s/p).

Quanto às vibrantes (trill) a mais comun é /r/, mas as fricativas são mais comuns do que as vibrantes, e apenas um pouco menos comuns do que as oclusivas ou as nasais. Já as sibilantes são mais comuns do que outras fricativas, "porque possuem mais energia acústica. Destacam-se de outros sons, mesmo em contextos de não-fala" (Ladefoged, 2012, s/p).

1 Tradução nossa: "and every known languages has sounds similar to two of these three".

2 "língua falada pelos incas” (Módolo, 2006-2007, p. 146).

3 Tradução nossa: "in which the back of the tongue touches the roof of the mouth a little further back, nearer the úvula".

4 Tradução nossa: "This is a wide ranges of possibilties, and sometimes [...] it is necessary to distinguish diferente types of each of these sounds."

5 Tradução nossa: "also languages that have nasal consonants at all the places of articulation".

6 Tradução nossa: “"because they have more acoustic energy. They stand out from other sounds even in non-speech contexts". 
Por último, quanto às consoantes laterais, afirma Ladefoged (2012) que o som mais comum entre as línguas do mundo é $/ 1 /$.

Especificamente quanto às línguas originárias, Storto e Demolin (2012) expõem que, nos sistemas fonológicos consonantais por eles consultados, encontram-se de 8 a 27 consoantes (línguas Pirahã e Yaruro, respectivamente), que se distinguem por 3 a 7 pontos e por 2 a 9 modos de articulação. Sobre os inventários fonológicos das línguas indígenas da América do Sul, concluem que todas as línguas possuem ao menos os seguintes segmentos: "(1) três oclusivas desvozeadas $p, t$ e $k$, [...] (2) pelo menos uma fricativa, s ou $b$; (3) duas consoantes nasais $m$ e $n,[\ldots]$; (4) uma alveolar tap ou flap; (5) pelo menos um glide $w^{7}$ (Storto; Demolin, 2012, p. 333, grifos dos autores).

Feitas essas breves considerações sobre os inventários consonantais das línguas do mundo e das línguas originárias do Brasil, a seguir, deter-nos-emos em nosso objeto de estudo: a língua Aikanã.

\subsection{Sistema consonantal do Aikanã}

É o inventário fonético-fonológico uma das coisas que atribuem a uma língua o seu padrão sonoro característico. Ora, sendo as línguas originárias essencialmente ágrafas, de tradição oral, é claro que o sistema fonético-fonológico se torna ponto principal no estudo de quaisquer uma delas (veja-se, inclusive, a tendência de, ao propor grafia para tais línguas, incluir somente letras que mais se assemelhem aos sons). Consequentemente, traçar o sistema fonético-fonológico da língua Aikanã, assim como de outras línguas originárias, é passo primordial para melhor visualizá-las e, assim, servir de base para estudos vindouros.

A análise comparativa aqui proposta permite verificar variações e mudanças nos sistemas linguísticos e, no nosso caso, no sistema fonético-fonológico, mais especificamente, no sistema consonantal da língua $\mathrm{Ai}^{-}$ kanã. Assim sendo, a seguir, apresentamos, cronologicamente, alguns estudos já realizados sobre o assunto.

Tradução nossa: "(1) three voiceless stops $p, t$ and $k,[. .$.$] (2) at least one fricative, sor$ $h$; (3) two nasal consonants $m$ and $n,[\ldots]$ (4) an alveolar tap or flap, [...] (5) at least one glide $w[\ldots] "$. 


\subsubsection{Resumo dos trabalhos analisados}

O primeiro trabalho é o de Vasconcelos (2002), cujos dados foram coletados em 1988, 1991, 1992 e 1994, a partir de, principalmente, três falantes da língua Aikanã. A pesquisa, que teve como foco maior descrição de cunho estruturalista da língua originária, tendo em vista a quase ausência de estudos registrados, no que concerne ao inventário sonoro, intentou descrever e analisar a "fonologia [...] a partir de uma abordagem segmental.", apresentando e discutindo "os respectivos quadros fonéticos e fonológicos das dezesseis (16) consoantes" e das "dez (10) vogais, das quais seis (06) são orais e quatro (04) são nasais."(Vasconcelos, 2002,p. 8). Expõe a autora que, quanto ao inventário das consoantes, não se incluem

[...] alguns sons que são claramente empréstimos da língua nacional, como a oclusiva velar sonora $[\mathrm{g}]$ e as fricativas $[\mathrm{f}, \mathrm{v}, \mathrm{z}, \mathrm{Z}]$, os quais são observados na fala cuidadosa, em nomes de pessoas e de localidades ou regiões que, necessariamente figuram na fala dos Aikanã. No entanto, como é de se esperar, no discurso normal ou rápido, os falantes quase sempre fazem a substituição de cada um dos referidos sons pelo som correspondente mais próximo em sua própria língua. Portanto, quando figurarem nos dados, tais sons estarão sendo considerados meramente como empréstimos. (Vasconcelos, 2002, p. 9).

Ao apresentar seus quadros fonéticos e fonológicos do sistema consonantal, classifica as consoantes, em conformidade aos parâmetros articulatórios, em: oclusivas, africadas, fricativas, nasais, líquidas, glides e glotais. Sobre as glotais, expõe:

Como afirmado acima, na sessão que trata do sistema consonantal, existe um fenômeno de alternância envolvendo a ocorrência das glotais oclusiva e fricativa ['] e [h], respectivamente, que pode ser explicado de forma mais adequada em um tratamento conjunto das duas consoantes. À primeira olhada, pode-se pensar que a presença ou ausência de um desses sons não tem conseqüências no que diz respeito ao significado, especialmente antes de vogais no início de palavras. Nesse ambiente, há registros de dados nos quais são verificadas três possibilidades: a oclusiva glotal ['], a fricativa glotal [h], ou ainda zero, i.e. a mesma palavra pode se iniciar apenas com a vogal [...] uma observação cuidadosa do fenômeno mostra regularidade de ocorrência, tanto da oclusiva, quanto da fricativa, suficiente para justificar a 
proposta de que elas, de fato, devem ser analisadas como fonemas independentes. [...] Já no caso da fricativa glotal, a presença versus ausência de /h/ não implique em diferença de significado. No entanto, a proposta de que este som constitui-se em um fonema independente é uma hipótese plausível. [...] É ainda previsível, numa corrente de fala rápida, a ocorrência de ['] entre sílabas, quaisquer sílabas. (Vasconcelos, 2002, p. 19-22).

A tabela I, a seguir, elenca as consoantes do inventário fonológico da língua Aikanã resultante do trabalho de Vasconcelos (2002).

Tabela I - Quadro fonológico das consoantes da língua Aikanã: Vasconcelos (2002)

\begin{tabular}{|l|l|l|l|l|l|l|l|}
\hline \multicolumn{1}{|c|}{ Modo/ponto } & Bilabial & Dental & Alveolar & $\begin{array}{c}\text { Alveolar } \\
\text { palatal }\end{array}$ & Palatal & Velar & Glotal \\
\hline OCLUSIVA & & & & & & & \\
\hline Surda & $\mathrm{p}$ & $\mathrm{t}$ & & & & $\mathrm{k}$ & $\mathrm{?}\left({ }^{`}\right)$ \\
\hline Sonora & $\mathrm{b}$ & $\mathrm{d}$ & & & & & \\
\hline AFRICADA & & & & & & & \\
\hline Surda & & & & $\mathrm{t} f(\mathrm{x})$ & & & \\
\hline FRICATIVA & & & & & & & \\
\hline Surda & & $\mathrm{s}$ & & & & & $\mathrm{h}$ \\
\hline Sonora & & $\mathrm{z}$ & & & & & \\
\hline NASAIS & & & & & & & \\
\hline Sonora & $\mathrm{m}$ & $\mathrm{n}$ & & & $\tilde{n}$ & & \\
\hline LÍQUIDAS & & & & & & & \\
\hline Flap & & & $\mathrm{r}$ & & & & \\
\hline SEMI-VOGAL & & & & & & & \\
\hline Oral & $\mathrm{w}$ & & & & $\mathrm{j}(\mathrm{y})$ & & \\
\hline
\end{tabular}

Fonte: Vasconcelos (2002, p. 10). 
Sobre o inventário consonantal da língua Aikanã, expõe Vasconcelos (2002) que, mesmo a aspiração não sendo "um traço fonológico no Aikanã, as oclusivas surdas podem ser foneticamente aspiradas ([ph], [th], [kh]) e a velar/k/ quase sempre o é", principalmente “antes da vogal anterior alta /i/". Além disso, é “também, de natureza fonética, a ocorrência de uma oclusão glotal precedendo uma consoante, principalmente em início de palavras e enunciados." (Vasconcelos, 2002, p. 11).

O segundo estudo utilizado nesta análise comparativa é o de Silva (2012), que utiliza dados dos nove meses em que viveu na Terra Indígena Tubarão Latundê, tendo dois principais informantes: Raimunda e Mário Aikanã. Seu trabalho resultou no Dicionário de raízes da língua Aikanã, que conta com “1.300 entradas e 1.640 exemplos" que intentam "ser um ponto de referência documental da língua aikanã e uma valiosa ferramenta pedagógica para a Educação Escolar dos aikanã, massacá e cassupá.”(Silva, 2012, p. 13).

Nas palavras de Silva (2012), foram poucos os "estudos foram feitos sobre essa língua aikanã. As iniciativas foram de Carlson (1986), Hilton (1993), seguido de Voort depois de estudar a língua vizinha kwazá.”. Além desses, cita a tese de Vasconcelos (2002), com a qual também trabalhamos, e afirma que "problemas fonológicos (contaminação nasal, sistema tonal), dentre outros importantes, continuam sem estudo." (Silva, 2012, p. 13).

Em suas "Notas fonológicas", apresenta um inventário de 13 consoantes. Dentre essas, três teriam estatuto fonêmico duvidoso: $/ \mathrm{t} / /$ e $/ \mathrm{d}_{3} /$ “poderiam ser alofones, respectivamente, de ts e dð antes de vogais anteriores" (Silva, 2012, p. 16), e /?/ possuiria "mais uma função demarcativa que fonêmica." (Silva, 2012, p. 17).

\section{Tabela II - Quadro das consoantes da língua Aikanã: Silva (2012)}

\begin{tabular}{|l|l|l|l|l|l|l|}
\hline & Labial & Dental & Alveolar & Pós-alveolar e Palatal & Velar & Glotal \\
\hline Obstruintes surdas & $\mathrm{p}$ & $\mathrm{ts}$ & $\mathrm{t}$ & $(\mathrm{t} f)$ & $\mathrm{k}$ & $(\mathrm{s})$ \\
\hline Obstruintes sonoras & $\mathrm{b}$ & $\mathrm{d} \delta$ & $\mathrm{d}$ & $(\mathrm{d} 3)$ & & \\
\hline Soantes & $\mathrm{w}$ & & $\mathrm{f}$ & & & $\mathrm{h}$ \\
\hline
\end{tabular}

Fonte: Silva (2012, p. 15) 
Sobre os dados expostos na tabela II, a autora explicita:

ts realiza-se como [ts] entre vogais e [s] em início de palavra.

b forte ou moderadamente laringalizado [b]; nunca é pré-nasalizada.

d forte ou moderadamente laringalizado [d]; nunca é pré-nasalizada.

d $\mathbf{d}[\mathrm{d} \delta]$ [ð] (a contraparte oclusiva desta africada dental apaga-se em início de palavra).

$\mathbf{w}$ realiza-se como $[\beta]$ antes de vogais anteriores e como $[\mathrm{w}]$ antes de vogal não-anteriores. $\mathrm{O}$ seu estatuto fonêmico não parece apresentar problema, como o mostra a oposição entre uwi [ußi] paca e ui [ui] montanha.

r de distribuição limitada, este fonema só aparece entre vogais, realizando-se como [r] ou [1]. O seu estatuto fonêmico não parece apresentar problema, como o mostra o seguinte par mínimo: dadahaz̃ estou melhor v. darahã̃ está frouxo, ou o par quase mínimo: ãdy porco-espinho v. ãryoa cachorro.

$\mathbf{h}$ de distribuição limitada, este fonema só aparece em início de morfemas

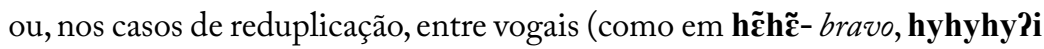
macaco sp.).

d3 realiza-se como [dz] ou [j] antes de vogal oral anterior, como [j] antes de vogal não-anterior, e como [j] ou [n] antes de vogal nasal. Seu estatuto fonêmico, assim como de ț , será comentado abaixo. (Silva, 2012, p. 15).

Além dessas questões, diz a autora que "m, n, nñ ð, etc., são apenas alofones nasalizados sem estatuto fonêmico próprio.” (SILVA, 2012, p. 16, grifos da autora); o que acontece é uma "contaminação nasal regressiva", como em

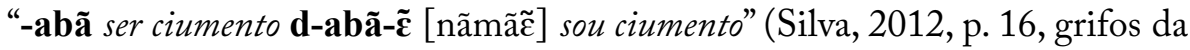
autora). Diz ainda que,

Pelas mesmas razões, há muita flutuação, da parte dos falantes, entre realizações orais ou nasais. Por exemplo:

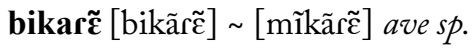

dydã [dynã] [nỹnã] cará (Silva, 2012, p. 16, grifos da autora).

Em conformidade ao exposto por Storto e Demolin (2012, p. 372), no nível suprassegmental do inventário fonêmico do Aikanã, "não está claro se há tons contrastantes", e apresenta o seguinte quadro consonantal: 


$\begin{array}{llllll}\text { stops: } & \mathrm{p} & \mathrm{t} & & \mathrm{k} & \text { ? } \\ & \mathrm{b} & \mathrm{d} & & & \\ \text { frics: } & & \mathrm{s} & & & \mathrm{h} \\ & & \mathrm{\partial} & & & \\ \text { affr: } & & \mathrm{ts} & & \\ \text { nas: } & \mathrm{m} & \mathrm{n} & \mathrm{j} & & \\ \text { tap: } & & \mathrm{r} & & & \\ \text { approxs: } & \mathrm{w} & & \mathrm{y} & \end{array}$

Fonte: Storto e Demolin (2012, p. 372)

No quarto trabalho por nós elencado, Voort (2013), a partir de pesquisas anteriores in loco e de textos por ele publicados, apresenta "um pequeno esboço preliminar da língua” Aikanã (Voort, 2013, p. 360). Para o autor, quanto ao seu inventário consonantal, o Aikanã possui " 16 fonemas: /p, b, t, d, k, ?, h, ts, tx, m, n, ñ, r, w, z, y/.”(Voort, 2013, p. 362). Esclarece, sobre as consoantes, que:

No início da palavra, o /ts/ é frequentemente pronunciado como [s], mas entre vogais é frequentemente [ts], com alguma variação livre com [s]. O /tx/ é geralmente $[\mathrm{t} f]$, mas $[\delta]$ foi observado também. [...] O /z/ é normalmente pronunciado como a fricativa [ð], e às vezes como laminal [z], e pode ser nasalizado entre vogais nasais, assemelhando-se $\mathrm{a}[\mathrm{n}] . \mathrm{O} / \mathrm{k} /$ às vezes recebe palatalização [kj] antes de [e]. O /y/ é pronunciado normalmente como [j], mas antes do [i] e [ø] é pronunciado como [3]. (Voort, 2013, p. 362).

Por fim, Storto (2019) expõe um inventário da língua Aikanã composto por 16 consoantes: oclusivas, fricativas, africadas, nasais, glides e o tepe / $/$ /, a saber:

ocls: $\mathrm{p} \quad \mathrm{t} \quad \mathrm{k}$ ?

b d

fric: $\quad \mathrm{s}$

$\mathrm{h}$

afr: $\quad$ ts

nas: $\mathrm{m} \quad \mathrm{n} \quad \mathrm{j}$

tepe: $\quad \mathrm{I}$

glides: $\mathrm{w} \quad \mathrm{j}$

Fonte: Storto (2019, p. 145) 
Como pudemos verificar, há divergências nos inventários apresentados por Vasconcelos (2002), Silva (2012), Storto e Demolin (2012), Voort (2013) e Storto (2019). Sobre tal controvérsia, é mister relembrar que,

Como todas as demais, as línguas dos povos indígenas do Brasil são inteiramente adequadas à plena expressão individual e social no meio físico e social que tradicionalmente têm vivido esses povos. Embora diferentes, elas compartilham do que todas as quase seis mil línguas do mundo têm em comum: são manifestações da mesma capacidade de comunicar-se pela linguagem. Essa capacidade é uma qualidade desenvolvida pela espécie humana e se caracteriza por princípios e propriedades que, presentes em todo homem, facultam a qualquer criança desenvolver o domínio de qualquer língua, sempre que exposta ao contato com falantes dessa língua. Da mesma forma, permitem a qualquer adulto, com maior ou menor esforço, aprender línguas diferentes da sua própria.

Embora constituídas a partir de princípios e propriedades comuns, as línguas estão sujeitas a grande número de fatores de instabilidade e variação, que determinam nelas forte tendência à constante alteração. Essa tendência é normalmente contrabalançada pela necessidade de mútuo ajuste entre os indivíduos de uma mesma comunidade social, ajuste sem o qual não se cumpriria a finalidade básica da língua, que é a comunicação explícita e, quando possível, fácil.” (Rodrigues, 2000, p. 17-8).

Em Tondineli (2020), identificamos a mesma variabilidade nos inventários vocálicos, provavelmente pelo fato de as pesquisas terem sido feitas em momentos e com falantes diferentes. Junte-se a isso o contato com a língua portuguesa, que pode ter promovido variações e/ou mudanças na língua $\mathrm{Ai}^{-}$ kanã; entretanto, tal fato não é o foco desta análise comparativa e, com certeza, necessita de investigações mais pontuais sobre a questão.

Expostos as pesquisas consultadas, a seguir, realizamos a análise comparativa do inventário consonantal da língua indígena Aikanã.

\subsubsection{Inventário consonantal do Aikanã: análise comparativa}

Antes de iniciarmos a análise comparativa, vale lembrar, neste ponto, que o objetivo desta comparação não é o de segmentar as consoantes da língua 
Aikanã em sistema fonético ou fonológico, mas sim de efetuar checagem do provável quadro consonantal.

Retomando os dados dos estudos elencados no subitem 3.1.1 (Vasconcelos, 2002; Silva, 2012; Storto; Demolin, 2012; Voort, 2013; Storto, 2019), temos o seguinte quadro de consoantes da língua Aikanã, construído em conformidade ao que se apresenta no Alfabeto Fonético Internacional:

Tabela III - Dados comparativos do inventário consonantal do Aikanã

\begin{tabular}{|c|c|c|c|c|c|c|c|c|c|c|c|c|c|c|c|c|c|c|c|c|c|c|}
\hline & $\mathrm{p}$ & $\mathrm{b}$ & ts & dू̄ & $\mathrm{t}$ & $t^{x}$ & d & t $\int$ & $\mathrm{d}_{3}$ & $\mathrm{k}$ & $?$ & $\mathrm{~m}$ & $\mathrm{n}$ & $\mathrm{n}$ & $\mathrm{r}$ & r & $\mathrm{s}$ & z & $\mathrm{h}$ & ơ & $\mathrm{j}$ & $\mathrm{w}$ \\
\hline Vasconcelos (2002) & $\mathrm{x}$ & $\mathrm{x}$ & & & $\mathrm{x}$ & & $\mathrm{x}$ & $\mathrm{x}$ & & $\mathrm{x}$ & $\mathrm{x}$ & $\mathrm{x}$ & $\mathrm{x}$ & $\mathrm{x}$ & & $\mathrm{x}$ & $\mathrm{x}$ & $\mathrm{x}$ & $\mathrm{x}$ & & $\mathrm{x}$ & $\mathrm{x}$ \\
\hline Silva (2012) & $\mathrm{x}$ & $\mathrm{x}$ & $\mathrm{x}$ & $\mathrm{x}$ & $\mathrm{x}$ & & $\mathrm{x}$ & $\mathrm{x}$ & $\mathrm{x}$ & $\mathrm{x}$ & $\mathrm{x}$ & & & & $\mathrm{x}$ & & & & $\mathrm{x}$ & & & $\mathrm{x}$ \\
\hline $\begin{array}{l}\text { Storto e Demolin } \\
\text { (2012) }\end{array}$ & $\mathrm{x}$ & $\mathrm{x}$ & $\mathrm{x}$ & & $\mathrm{x}$ & & $\mathrm{x}$ & & & $\mathrm{x}$ & $\mathrm{x}$ & $\mathrm{x}$ & $\mathrm{x}$ & $\mathrm{x}$ & & $\mathrm{x}$ & $\mathrm{x}$ & & $\mathrm{x}$ & $\mathrm{x}$ & $\mathrm{x}$ & $\mathrm{x}$ \\
\hline Voort (2013) & $\mathrm{x}$ & $\mathrm{x}$ & $\mathrm{x}$ & & $\mathrm{x}$ & & $\mathrm{x}$ & $\mathrm{x}$ & & $\mathrm{x}$ & $\mathrm{x}$ & $\mathrm{x}$ & $\mathrm{x}$ & $\mathrm{x}$ & & $\mathrm{x}$ & & $\mathrm{x}$ & $\mathrm{x}$ & $\mathrm{x}$ & $\mathrm{x}$ & $\mathrm{x}$ \\
\hline Storto (2019) & $\mathrm{x}$ & $\mathrm{x}$ & & & $\mathrm{x}$ & & $\mathrm{x}$ & & & $\mathrm{x}$ & $\mathrm{x}$ & $\mathrm{x}$ & $\mathrm{x}$ & $\mathrm{x}$ & & $\mathrm{x}$ & $\mathrm{x}$ & & $\mathrm{x}$ & & $\mathrm{x}$ & $\mathrm{x}$ \\
\hline
\end{tabular}

Fonte: Elaboração própria.

Em relação aos sons consonantais apresentados na tabela III, dois deles merecem consideração. O primeiro é a oclusiva glotal [?], consoante que Silva (2012) considera duvidosa, contrapondo ao que foi elencado por Vasconcelos (2002), Storto e Demolin (2012), Voort (2013) e Storto (2019).

O segundo ponto diz respeito à $(\mathrm{t} f)$ e $(\mathrm{d} 3)^{8}$, em posição de oclusiva pós-alveolar, só listado por Vasconcelos (2012). Tais segmentos foram considerados duvidosos por Silva (2012), mas, como expõem Sousa e Tondineli (2019), [t $f]$ e [d3] podem ser considerados alofones de /t/ e /d/, respectivamente. Vale ressaltar, ainda, sobre [t $\left.\int\right]$, que encontramos, nos estudos elencados anteriormente, /ts/ como obstruinte dental surda (Silva, 2012) e /ts/ como africada alveolar (Storto, 2019).

Já em Voort (2013), temos / $\mathrm{t}^{\mathrm{x}} /$ como fonema oclusivo surdo alveolar e /ts/ como fonema africado alveolar. Lembremos, entretanto, que: "No início

8 Neste trabalho, usaremos parênteses para apresentar sons que não comprovamos serem fonemas ou alofones. Lembramos que o objetivo desta análise não é o de segmentar o inventário consonantal da língua Aikanã em sistema fonético ou fonológico, como já dissemos anteriormente. 
da palavra, o /ts/ é frequentemente pronunciado como [s], mas entre vogais é frequentemente [ts], com alguma variação livre com [s]. O / tx/ é geralmente [t $\left.\int\right]$, mas [ $\left.\int\right]$ foi observado também." (Voort, 2013, p. 362).

Para nós, como elencamos na tabela $3, / \mathrm{t} /$ / é fricativa alveolar, ou africada, como usualmente a conhecemos no português brasileiro.

Para tentar nos ajudar na melhor visualização do quadro consonantal da língua Aikanã, a seguir, apresentamos dados preliminares de algumas de nossas transcrições. Tendo em vista a complexidade do quadro consonantal da língua e a morosidade do trabalho do pesquisador para se obter bons resultados, esclarecemos que os dados elencados a seguir não são conclusivos e podem estar sujeitos a revisões, principalmente por nossos estudos ainda estarem em andamento, tendo sido bruscamente interrompidos pela pandemia de COVID-19, o que nos impossibilitou o contato com o povo originário Aikanã.

A partir das transcrições realizadas, obtivemos os seguintes resultados em relação às consoantes:

a) Oclusivas: [pe’'], pa’i, "arma, cartucho, pólvora, chumbo" (Silva et al., s/d, p. 29); [ba'ba], ba'ba, "pai, tio mais velho" (Silva et al., s/d, p. 12); [tu'i], tu'i, "garfo" (Silva et al., s/d, p. 32); [d ‘’ne], duna, "cará (planta da família das dioscoreásceas [...])" (Silva et al., s/d, p. 79); [ura'kai], ürakari, "alimento, comida" (Silva, 2012, p. 135); [tu'kenirẽ], tukaekaẽ, "coloquei”(Silva et al., s/d, p. 164);

b) Nasais: [maru'apidi], maruapidi, "vaca (neologismo)" (Silva et al., s/d, p. 63); [he'ne], hena, "então, naquele tempo" (Silva, 2012, p. 65); ['n\&E], yẽ, "carne" (Silva et al., s/d, p. 201);

c) Tepe: [aru’wa], ãroa, "jacaré” (Silva et al., s/d, p. 206);

a) Fricativas: [kiri'puase], kiripasa, "tartaruga, jabuti”(Silva, 2012,p. 93); ['kE'za], keza, "casa” (Silva et al., s/d, p. 24); [t/f' t t $\mathbf{i p u}$ ], xixipu, "gafanhoto, grilo"(Silva et al., s/d, p. 74); [tłke’mizakeẽ], tükemakukaẽ, de tü-, "estar grávida [...] kurezamii detiaye tükemakukaẽ o rapaz engravidou a mulher.”(Silva et al., s/d,p.163, grifos dos autores); [hõ̃e], de hũ- "roncar" (Silva et al., s/d, p. 138);

b) Aproximantes: [ðجare'i], ware'i, de "ware- $v$. deslocar-se (com sufixo apropriado: andar, ir, vir, trazer, levar, entrar, sair, seguir, passar, subir, descer)" (Silva, 2012, p. 139, grifo da autora); [ary'wa] ãrüoa, “cão, cachorro" (Silva et al., s/d, p. 42); ['ja], ya, "astro (sol, lua), relógio (neologismo)"(Silva et al., s/d, p. 36). 
Tais dados iniciais resultam, por conseguinte, no quadro consonantal da língua Aikanã dado a seguir.

Tabela IV - Inventário consonantal do Aikanã: quadro demonstrativo

\begin{tabular}{|c|c|c|c|c|c|c|c|c|c|c|c|}
\hline & Bilabial & Labiodental & Dental & Alveolar & $\begin{array}{l}\text { Pós- } \\
\text { alveolar }\end{array}$ & Retroflexo & Palatal & Velar & Uvular & Faringal & Glotal \\
\hline Oclusiva & $\mathrm{p} \quad \mathrm{b}$ & & & d & & & & $\mathrm{k}$ & & & $?$ \\
\hline Nasal & $\mathrm{m}$ & & & $\mathrm{n}$ & & & $\mathrm{n}$ & & & & \\
\hline \multicolumn{12}{|l|}{ Trill } \\
\hline Tepe & & & & s & & & & & & & \\
\hline Fricativa & & & & $\mathrm{s} \quad \mathrm{z}$ & (t) $\int 3$ & & & & & & $\mathrm{~h}$ \\
\hline \multicolumn{12}{|c|}{ Fricativa lateral } \\
\hline Aproximante & & & $\partial$ & & & & $\mathrm{j}$ & $\mathrm{w}$ & & & \\
\hline $\begin{array}{l}\text { Aproximante } \\
\text { lateral }\end{array}$ & & & & & & & & & & & \\
\hline
\end{tabular}

Fonte: Elaboração própria.

Em relação aos outros trabalhos apresentados, cujos dados encontram-se na tabela 3, verificamos que a fricativa vozeada pós-alveolar (3) é o único som discordante. Como posto anteriormente, em Silva (2012), aventa-se a possibilidade do alofone [d3], o que parece divergir do dado por nós encontrado, em que tal som ([tłke'mızakeẽ]) parece-nos não condicionado à oclusiva /d/, podendo, inclusive, ser um fonema - o que ainda carece de maiores investigações.

Retomando os preceitos universais elencados por Ladefoged (2012) sobre os inventários consonantais das línguas do mundo, verifica-se que o Aikanã se inclui no percentual de línguas que possuem as oclusivas desvozeadas $/ \mathrm{p} /, \mathrm{t} / \mathrm{e} / \mathrm{k} /$. Já em relação às fricativas, o que se verifica é a ausência daquelas elencadas como mais comuns por Ladefoged (2012): /f/ e /v/. No quadro sonoro das consoantes do Aikanã, o que verificamos é a ocorrência das fricativas (s), ( $\mathrm{z}),(\mathrm{t} f)$ e (h). Tais dados ilustram bem o fato de os autores afirmarem que as sibilantes preponderam em relação às fricativas, "porque possuem mais energia acústica. Destacam-se de outros sons, mesmo em contextos de não-fala"' (Ladefoged, 2012, s/p).

\footnotetext{
9 Tradução nossa: “'because they have more acoustic energy. They stand out from other sounds even in non-speech contexts".
} 
$\mathrm{Na}$ mesma linha, não se encontram, na língua Aikanã, a vibrante /r/ e a lateral /1/, ambas elencadas por Ladefoged (2012) como as mais comuns nas línguas em geral.

Quanto aos sons /t/, /d/ e /n/, Ladefogedr (2012) dize que podem variar em seu ponto de articulação. Na língua Aikanã, todos os três são alveolares.

Sobre as nasais, têm-se as duas listadas por Ladefoged (2012) como as de maior ocorrência, (m) e (n), assim como (y), nasal que também aparece com maior ocorrência nas línguas do mundo.

Adentrando nos sistemas sonoros das línguas originárias, verificamos que o inventário consonantal da língua Aikanã, com 18 segmentos, encaixa-se na estrutura daqueles consultados por Storto e Demolin (2012), os quais possuíam de 8 a 27 consoantes, que, no nosso caso, distinguem-se por 7 pontos e por 4 modos de articulação.

Em relação aos cinco pontos comuns entre as línguas originárias apresentados por Storto e Demolin (2012), a língua Aikanã encaixa-se em todos eles: possui as três oclusivas desvozeadas listadas $(/ \mathrm{p} /, / \mathrm{t} / \mathrm{e} / \mathrm{k} /)$, mais de uma fricativa, as consoantes nasais $/ \mathrm{m} / \mathrm{e} / \mathrm{n} /$, o tepe $/ \mathrm{r} /$ e o glide $/ \mathrm{w} /$.

\section{Considerações finais}

Este trabalho teve o objetivo de apresentar um quadro fonético-fonológico comparativo quanto às consonates da língua Aikanã, com o fim de comparar os sistemas elencados nos Vasconcelos (2002); Silva (2012); Storto e Demolin (2012); Voort (2013); Storto (2019) para, assim, efetuar checagem do provável quadro consonantal dessa língua originária.

A partir da montagem do quadro comparativo, pudemos verificar a controvérsia de sua constituição; por exemplo, em relação à oclusiva glotal [?], consoante ora considerada duvidosa (Silva, 2012), ora posta como segmento do sistema consonantal do Aikanã (Vasconcelos, 2002; Storto; Demolin, 2012; Voort, 2013; Storto, 2019).

Para tentar mitigar tais dúvidas, expusemos dados de transcrições preliminares feitas por nós, chegando a um quadro consonantal composto por 18 
segmentos: (p, b, t, d, k, ?, m, n, n, r, s, z, t f , 3, h, ð, j, w). tal quadro, como expusemos é condizente com os preceitos elencados por Ladefoged (2012) sobre os inventários consonantais das línguas do mundo, assim como contempla os itens citados por Storto e Demolin (2012) como comuns às línguas originárias: (1) a presença de "três oclusivas desvozeadas $p, t$ e $k$ [...] (2) pelo menos uma fricativa, s ou $h$; (3) duas consoantes nasais $m$ e $n$, [...]; (4) uma alveolar tap ou flap; (5) pelo menos um glide w" (Storto; Demolin, 2012, p. 333, grifos dos autores).

Vale lembrar, por último que tais dados são iniciais e que, agora, a partir do que encontramos em relação ao inventário consonantal da língua Aikanã, será possível verificar com maior segurança qual segmento encaixa-se em seus quadros fonético e/ou fonológico.

Ressaltamos que este trabalho não compreende uma análise exaustiva da língua. O que intentamos aqui foi apenas apresentar alguns aspectos do sistema consonantal do Aikanã. Há, portanto, espaço para o tratamento mais aprofundado das questões de natureza fonético-fonológicas dessa língua originária.

\section{REFERÊNCIAS}

EBERHARD, David M. Em defesa das línguas minoritárias do Brasil. Anápolis, GO: Associação Internacional de Linguística/SIL, 2013. Disponível em: <https://www.researchgate.net/publication/275466032_ EM_DEFESA_DAS_LINGUAS_MINORITARIAS_DO_BRASIL >. Acesso em: 21 ago. 2020.

LADEFOGED, Peter. Vowels and consonants. 3. ed. Revisado por Sandra Ferrari Disner. Oxford: Wiley-Blackwell, 2012.

RICARDO, Beto; RICARDO Fany (Eds.). Povos indígenas no Brasil: 2011-2016. São Paulo: Instituto Socioambiental, 2017. 
RODRIGUES, Aryon Dall'Igna. Panorama das línguas indígenas da Amazônia. In: QUEIXALÓS, F.; RENAULT-LESCURE, O. (Orgs.). As línguas amazônicas hoje. São Paulo: Instituto Socioambiental, 2000. p. 15-28.

RONDÔNIA. Censo populacional da Terra Indígena Tubarão Latundê. Vilhena: FUNAI, 2017.

SILVA, Maria de Fátima dos Santos da. Dicionário de raízes da língua Aikanã. 167 f. Dissertação (Mestrado em Ciências da Linguagem) - Departamento de Letras e Pedagogia, Fundação Universidade Federal de Rondônia, Guajará-Mirim, 2012.

SILVA, Maria de Fátima dos Santos da et al. Primeiro dicionário da língua Aikanã. Porto Velho: Secretaria Estadual de Educação de Rondônia, s/d.

SOUZA, Antônio Francisco de et al. Aikanã. Panewa especial, Porto Velho, p. 70-73, 2015.

STORTO, Luciana; DEMOLIN, Didier. The phonetics and phonology os South American langauages. In: CAMPBELL, Lyle; GRONDONA, Verónica (Eds.). The indigenous languages of South America: a comprehensive guide. Berlin/Boston: Mouton de Gruyter, 2012. p. 331-390. (The world of linguistics; 2).

STORTO, Luciana. Línguas indígenas: tradição, universais e diversidade. Campinas, SP: Mercado de Letras, 2019.

TONDINELI, Patrícia Goulart. O sistema fonológico das vogais orais na língua indígena Aikanã. Revista Linguagem \& Ensino, Pelotal, RS, v. 23, n. 4, p. 900-917, 2020.

TONDINELI, Patrícia Goulart. Classificação tipológica da língua indígena Aikanã. 2020a. (No prelo).

UNESCO. Atlas Interativo de Línguas em Perigo. 2010. Disponível em: <http://www.unesco.org/languages-atlas/>. Acesso em: 22 ago. 2018. 
VASCONCELOS, Ione Pereira. Aspectos da fonologia e morfologia da língua aikanã. Tese (Doutorado em Linguística) - Programa de Pós-graduação em Letras e Linguística, Universidade Federal de Alagoas, Maceió, 2002.

VOORT, Hein van der. Fala fictícia fossilizada: o tempo futuro em Aikanã. Bol. Mus. Para. Emílio Goeldi. Cienc. Hum., Belém, v. 8, n. 2, p. 359-377, maio-ago. 2013.

VOORT, Hein van der. Aikanã. 2010. (comunicação pessoal). Disponível em: <http://linguistics.berkeley.edu/ saphon/es/inv/Aikana.html>. Acesso em: 02 setembro 2020.

WETZELS, Leo. Estudos fonológicos das línguas indígenas brasileiras. Rio de Janeiro: Editora UFRJ, 1995. 


\section{CONTRIBUIÇÕES DA FONÉTICA ACÚSTICA PARA UM DIAGNÓSTICO DIFERENCIAL NA APRAXIA DE FALA}

Marian Oliveira

Vera Pacheco

Carolina Lacorte Gruba

Andréia Alves Cordeiro

\section{INTRODUÇÃO}

É inquestionável que as elaborações teóricas do suíço Ferdinand de Saussure foram fundamentais para o desenvolvimento da Linguística enquanto ciência autônoma. A sua obra póstuma Curso de Linguística Geral, publicada em 1916, três anos após sua morte, traz os princípios básicos dessa nova ciência, bem como traz as ideias basilares das diferentes subáreas da Linguística, tais como a Morfologia, a Sintaxe, a Semântica e, obviamente, a Fonética e a Fonologia, especificamente, a partir da dicotomia langue x parole (língua x fala).

Ao tratar da dicotomia língua $\mathrm{x}$ fala, Saussure evidencia fatos de linguagem da ordem da construção coletiva, de um sistema de valores que se opõem uns aos outros, como um produto social, depositado na mente de cada falante de uma comunidade e, por isso, trata-se de um fato de linguagem homogêneo e abstrato - a língua, versus fatos de linguagem que são da ordem de um ato individual e sujeito a fatores externos e por isso heterogêneos e reais - a fala (Saussure [1916],1970).

A ideia de algo abstrato $\mathrm{x}$ real proposto por Saussure, ao tratar da dicotomia langue e parole, é igualmente encontrada nas concepções de Trubetzkoy ([1933], 1981) ao definir Fonética e Fonologia. Para o linguista russo, a Fonética quer "estudar os fatores materiais dos sons da fala" ao passo que a Fonologia quer estudar "não os sons, mas os fonemas ${ }^{1}$, isto é, os elementos imateriais" (Trubetzkoy, [1933], 1981, p.18). Segundo ele, grosseiramente falando, a Fonética "busca

1 Para Trubetzkoy ([1933] 1981) fonema é uma unidade abstrata, mínima, indivisível opositiva e significativa. 
descobrir o que de fato se pronuncia ao falar uma língua e a fonologia o que se crer pronunciar" (Trubetzkoy, [1933], 1981, p.19). Assim, podemos afirmar que Fonética estuda fatos da ordem da fala e a Fonologia fatos da ordem da língua.

Embora Trubetzkoy ([1933], 1981) defenda que Fonética e Fonologia sejam disciplinas distantes entre si ao ponto de que "nunca se porá suficiente destaque esta profunda diferença" (Trubetzkoy, [1933], 1981, p.19), trabalhos posteriores às suas obras mostram a indissociabilidade entre aspectos materiais e imateriais do componente sonoro. Exemplo dessa indissociabilidade pode ser visto na proposta do sistema de traços de Jakobson, Fant e Halle (1952), de base acústica, e na proposta de traços de Chomsky e Halle (1968), de base acústico-articulatória.

Os sistemas de traços propostos por Jakobson, Fant e Halle (1952) e por Chomsky e Halle (1968) nos evidenciam que, ao se investigar o componente sonoro de uma língua natural, aspectos materiais e imateriais dos sons podem ser considerados simultaneamente. Apesar disso, não podemos perder de vista, naturalmente, as exigências metodológicas específicas da Fonética e da Fonologia.

Considerando que a Fonética investiga o som na perspectiva material, caberá à Fonética investigar a) os mecanismos aerodinâmicos e articulatórios dos sons da fala, o que compete à Fonética Articulatória; b) as suas propriedades físicas, matéria de investigação da Fonética Acústica e c) os mecanismos de percepção desses sons pelo sistema auditivo; competência da Fonética $\mathrm{Au}$ ditiva ou Perceptual. À Fonologia caberá, com bases nas descrições fonéticas e por meio de um modelo, interpretar o valor do som para o sistema linguístico, ou seja, a parte imaterial do som.

Ao ter como como objeto de investigação os sons de uma língua, a Fonética e a Fonologia constituem subáreas da Linguística de extrema importância para a Fonoaudiologia, que é a ciência que cuida de todos os processos de comunicação humana e seu desenvolvimento e que tem como um dos focos de atenção a voz e a fala, tantos em seus aspectos de produção quanto de percepção. Com base na Fonética e na Fonologia, o fonoaudiólogo poderá realizar diagnósticos e adequar suas terapias com mais segurança. 
Tendo como norte a contribuição da Fonética e Fonologia para descrever, compreender e ajustar diagnósticos e terapias de fala, este trabalho propõe investigar acusticamente as fricativas produzidas por um sujeito com síndrome de Down (sD), ou T21, para diagnóstico diferencial da apraxia, que é a dificuldade de realização de movimentos motores, mesmo que o indivíduo tenha capacidade e vontade de realizá-los.

O presente trabalho busca responder as seguintes perguntas a) quais as implicações das alterações miofuncionais orofaciais na duração relativa e do centroide das fricativas do Português Brasileiro (PB) produzidas por indivíduo com T21?; b) de que forma a análise acústica da produção das fricativas por uma pessoa com Down pode contribuir para diagnósticos fonoaudiológicos mais precisos?

Para a nossa primeira pergunta temos a hipótese de que alterações miofuncionais orofaciais e motoras orais, como baixo tônus e mobilidade dos lábios, língua e bochechas, alterações na oclusão dentária, como mordida cruzada lateral e mordida aberta anterior, bem como demais alterações apresentadas pelo sujeito com Down, como dificuldades no planejamento motor oral, impactam sobremaneira nas características acústicas das fricativas por ele produzidas. Para a nossa segunda pergunta partimos da hipótese de que alterações nos valores das frequências das fricativas podem ser evidências robustas que sinalizam objetivamente problemas na produção dessa consoante concorrendo para um diagnóstico mais preciso.

O objetivo geral desta pesquisa foi analisar acusticamente as fricativas [f], [v], [s], [z], [S] e [3], em posição de onset, produzidas por um sujeito com T21, visando verificar como as especificidades do trato vocal e as características motoras da produção da fala apresentadas por este sujeito podem interferir nas características acústicas dos segmentos fricativos por ele produzidos. Buscamos cumprir os seguintes objetivos específicos: $i$ ) demonstrar que as especificidades do trato vocal e as características motoras interferem na produção do sinal acústico das fricativas; ii) demonstrar que a análise acústica pode ser útil para diagnóstico e terapias mais precisas nos casos de apraxia e transtornos de fala. 
Esperamos que a partir deste trabalho possamos contribuir para o desenvolvimento de outras pesquisas que aprofundem o tema, bem como incentivar os profissionais que atuam na avaliação e reabilitação da fala a utilizarem métodos de análises mais objetivos em sua atuação.

Organizamos este capítulo em 05 (cinco) seções principais, contando com essa introdução: em 2, argumentamos que a fonética acústica pode ser uma aliada do fonoaudiólogo que pode partir das premissas, por exemplo, da Teoria de Produção da Fala de Fant (1960), como suporte para fazer diagnósticos mais precisos e fidedignos; em 3 , apresentamos percurso metodológico que nos permitiu traçar uma análise acústica dos segmentos fricativos, produzidos por um adolescente com síndrome de Down, o qual, a partir dessa análise, foi diagnosticado com apraxia de fala; em 4, apresentamos os dados da análise do centroide e da duração das fricativas, mostrando as alterações encontradas na produção e a sua relação com a apraxia; em 5, apresentamos nossas considerações finais. Por fim, em 6, apresentamos as referências bibliográficas.

\section{FONÉTICA ACÚSTICA E FONOAUDIOLOGIA: PERSPECTI- VAS PARA DIAGNÓSTICO DE APRAXIA DE FALA}

Nesta seção, sem a presunção de sermos exaustivos, pretendemos demonstrar que a Fonética Acústica, mais precisamente os ensinamentos tirados da Teoria da Produção da Fala, de Fant (1960), pode ser uma aliada do fonoaudiólogo, que, a partir dos seus pressupostos teóricos e dos diversos aparatos metodológicos advindos desse modelo, pode atuar com mais objetividade, no sentido de que, para além da impressão auditiva, poderá fazer diagnósticos a partir de dados concretos, fidedignos, passíveis de mensuração. Essa conduta beneficiará o profissional, que poderá elaborar o diagnóstico correto e um protocolo de intervenção específico para as necessidades do paciente, e, sobremaneira, o paciente que receberá um tratamento totalmente pensado para a sua condição.

No âmbito do Núcleo Saber Down - Projeto de Pesquisa desenvolvido na Universidade Estadual do Sudoeste da Bahia, têm sido realizadas várias pesquisas com ênfase em aspectos articulatórios e acústicos aplicados a ques- 
tões de alterações de fala apresentadas por pessoas com síndrome de Down e autismo e com consequências para a prática fonoaudiológica. Para citar algumas: (Oliveira, 2011, Oliveira; Pacheco, 2012, Oliveira; D'Ângelis, 2012, Oliveira; Pacheco 2015; Gruba, 2018, Oliveira; Pacheco; Brito, 2019, Oliveira, 2020). Em sua maioria, essas pesquisas abordam aspectos fonéticos da fala de pessoas com T21, a partir do arcabouço de Fant (1960).

De acordo com a Teoria Fonte-Filtro, Fant (1960), os diferentes sons produzidos pela fala humana são decorrentes dos diversos movimentos que realizamos com os órgãos fonoarticulatórios. Estes movimentos são capazes de alterar a forma do trato vocal, gerando sons com qualidades auditivas e acústicas diferentes. Dessa forma, podemos assim dizer que o trato vocal funciona como uma espécie de filtro que, ao assumir diferentes configurações, é capaz de modificar o sinal acústico emitido, gerando os sons da fala, quais sejam, consoantes e vogais (Laver, 1994; Ladefoged; Maddieson, 1996; Kent; Read, 2015; Câmara Jr., 2015).

O sistema fonológico do Português Brasileiro (PB) comporta consoantes como oclusivas, fricativas, nasais, laterais e vibrantes. A classe das fricativas é uma das principais no $\mathrm{PB}$ e corresponde a $13,1 \%$ dos sons produzidos nessa língua. Elas são consideradas sons complexos, que possuem duração relativamente mais longa e que necessitam de uma maior precisão articulatória em sua produção, sendo resultantes da turbulência do ar causada por um estreitamento no trato vocal (Cirigliano et al, 2005, Ladefoged; Maddieson, 1996, Câmara Jr., 2015, Kent; Read, 2015).

Ladefoged e Maddieson (1996) observaram que a variação de um milímetro na posição articulatória durante a realização de uma fricativa pode resultar em diferenças na produção deste som. Ao realizarmos uma fricativa, é necessário que haja uma precisão articulatória maior para que o ruído turbulento seja produzido. Diferentemente da classe das oclusivas, as fricativas apresentam uma maior duração, o que exige que a articulação seja constante, ou seja, que o movimento articulatório realizado para sua produção seja mantido por maior tempo. (Ladefoged; Maddieson, 1996). 
A partir desses estudos, é possível concluir que quaisquer alterações nos órgãos fonoarticulatórios podem interferir diretamente na qualidade dos sons produzidos, principalmente na classe de sons fricativos.

Tendo em vista as características das consoantes fricativas, não seria um exagero pensar que a sua articulação por parte de falantes com T21 resulta numa atividade de alta complexidade, pois vários são os estudos que atestam grandes alterações no trato vocal de pessoas com essa condição. Pessoas com sD apresentam alterações orofaciais tais como a macroglossia ou língua aumentada, hipotonia dos músculos faciais, desalinhamento dentário, alterações mandibulares, fenda palato-ogival, entre outras e tais alterações interferem na articulação dos sons da fala, o que gera dificuldades na programação motora dos músculos orofaciais, troca de segmentos. Tudo isso dificulta a articulação dos sons e compromete o sinal acústico, que por sua vez compromete a percepção da fala. (Hamilton, 1996, Oliveira, 2011, Oliveira; D’Ângelis, 2012, Oliveira; Pacheco, 2012, Benigno et al, 2018).

Oliveira (2011) demonstra em sua pesquisa que as especificidades do trato vocal de pessoas com Down, principalmente no que se refere à hipotonia muscular geral e à orofacial, em particular, e à macroglossia, ou falsa macroglossia, ou cavidade oral pequena, levam a alterações na produção das vogais por estes sujeitos. $\mathrm{O}$ estudo realizado pela pesquisadora foi o primeiro no Brasil a avaliar a fala de pessoas com Down por meio da fonética acústica, especificamente, a partir dos pressupostos da Teoria de Produção da Fala, e a análise feita nos moldes desse modelo demonstrou ser eficaz na associação das características do trato vocal de pessoas com T21 com as alterações na fala apresentada por eles. Essa pesquisa, inclusive, muito pode ensinar aos terapeutas da fala sobre a trajetória articulatória percorrida por vogais produzidas por pessoas com Down que apresentem hipotonia e macroglossia. Essa pesquisa abriu as portas para a criação do Projeto Núcleo Saber Down (UESB/CNPq/ $\mathrm{MEC}$ ), que é um projeto de pesquisa e de ação, uma vez que ao mesmo tempo em que se faz pesquisa sobre aspectos fonético-fonológicos, processamento de leitura, aquisição de escrita, o sujeito investigado - a pessoa com Down - é atendido para estimulação global, ensino-aprendizagem de leitura e escrita etc. 
Outros estudos realizados no âmbito do Saber Down, como os de Gruba, Oliveira e Pacheco (2016, Gruba et al. (2017a), Gruba et al. (2017b), Gruba (2018) e Gruba et al (no prelo), demonstraram que as alterações nos órgãos fonoarticulatórios, bem como a dificuldade no planejamento motor oral apresentadas por sujeito com sD, podem comprometer a produção das fricativas labiodentais, alveolares e palatoalveolares, principalmente nas características acústicas de tais segmentos. As pesquisas desenvolvidas no espaço do Núcleo têm em comum, entre outras coisas, o fato de todas elas apontarem para uma possível aplicação dos achados fonéticos - acústicos, articulatórios - na prática fonoaudiológica.

Além das alterações estruturais que podem comprometer a produção da fala, principalmente na classe dos sons fricativos, estudos realizados por Hamilton (1993), Kumin (2006) e Rupela, Velleman e Andrianopoulos (2016) demonstram que as alterações de fala encontradas em sujeitos com T21 podem estar relacionadas a uma dificuldade de planejamento motor oral conhecida como apraxia de fala.

A apraxia da fala é caracterizada como alterações nas habilidades do planejamento motor oral, ou seja, dificuldade no sequenciamento e na combinação dos sons dentro das palavras, frases e sentenças. Além dessas características, a redução da precisão articulatória, inconsistência nos movimentos motores dos OFAs, dificuldade nas tarefas de diadococinesia oral (dificuldade na realização de movimentos rápidos e alternados), apagamento de segmentos e sílabas, dificuldade na coordenação da força durante a produção dos sons, e na imitação e produção das palavras, mesmo que familiares, etc. (Kumin, 2006; Rupela; Velleman; Andrianopoulos, 2016).

$\mathrm{Na}$ prática clínica fonoaudiológica, o profissional depara-se com pacientes que apresentam alterações na produção da fala, os instrumentos utilizados para avaliação são guiados, na maioria das vezes, pela análise da oitiva (Berti; Pagliuso; Lacava, 2009), ou seja, parte-se, principalmente, da impressão auditiva. Esta análise puramente auditiva pode não ser o suficiente para fornecer as informações necessárias sobre a fala, bem como sobre as eventuais alterações articulatórias do paciente, o que pode gerar interpretações equivocadas e, conse- 
quentemente, diagnósticos e terapias equivocadas. É necessário, pois, que esses profissionais lancem mão de métodos a partir dos quais possam fazer uma avaliação mais precisa e objetiva, para assim elaborar diagnósticos mais fidedignos.

A Fonética Acústica pode ser uma aliada do fonoaudiólogo, posto que, como observa Oliveira (2011), a Teoria Fonte Filtro oferece os subsídios necessários para o entendimento da relação acústico-articulatória na produção da fala, isto é, por meio dessa teoria, será possível deduzir como se dá a articulação dos segmentos produzidos pelos falantes, e, neste caso, pelos falantes com alteração de fala como os com Down, ao mesmo tempo em que fornece fundamentos para análise acústica da fala. Segundo a autora, a partir das características acústicas encontradas, é possível entender o quanto das características físicas desses sujeitos interfere na produção vocálica deles. (Oliveira, 2011, 110),

Ainda segundo Oliveira (2011, p. 110),

a partir das características acústicas encontradas, é possível que possamos entender o quanto das características físicas desses sujeitos interfere na produção vocálica deles. Segundo essa teoria, a geração de fontes acústicas e a filtragem delas pelo trato vocal resultam em sinal acústico. $\mathrm{O}$ trato vocal, ao assumir diferentes configurações na produção da fala, funciona como um filtro acústico que, a partir do sinal emitido, fornecerá pistas sobre a maneira como um som foi produzido.

Assim, se o paciente tem dificuldade em produzir uma vogal de forma prototípica, o fonoaudiólogo poderá, pela análise da configuração formântica, avaliar a natureza dessa dificuldade e propor terapias para ajuste da trajetória da língua dentro da cavidade oral, se mais recuada, se mais anteriorizada, se mais levantada ou mais abaixada, para controle de mandíbula tendo em vista as diferentes configurações de abertura/fechamento do trato oral a depender da vogal, bem como a configuração dos lábios, se arredondados ou não.

Os correlatos acústicos fornecerão os subsídios para determinação daquilo que em termos articulatórios o paciente apresenta. Se a dificuldade do paciente é de planejamento do movimento articulatório de uma consoante 
fricativa, por exemplo, dificuldade de distinguir, em termos de vibração de pregas vocais, uma fricativa surda de uma fricativa sonora. Ele pode suspeitar de um caso de apraxia de fala, por meio da análise da duração, do centroide dessa consoante etc. Por essas razões é que acreditamos que a fonética acústica possa ser uma aliada do fonoaudiólogo e usada como ferramenta importante no estabelecimento de um diagnóstico diferencial, como o de apraxia de fala. Nas seções seguintes, esperamos demonstrar os benefícios que uma análise acústica pode trazer para os profissionais que lidam com pacientes com transtorno de fala. Procuraremos demonstrar isso a partir da análise acústica de fricativas produzidas por um adolescente com sD.

Além da análise das fricativas, pretendemos, por meio deste estudo, demonstrar a importância de instrumentos objetivos na avaliação da fala, bem como a contribuição destas ferramentas em diagnósticos diferenciais, como no caso, a apraxia de fala.

Para a análise acústica realizada neste estudo, consideramos os parâmetros da Duração Relativa (DR) e do centroide. A escolha por analisar a duração relativa do segmento e não a duração absoluta se deve ao fato de a DR permitir uma normalização os dados obtidos, diminuindo assim os efeitos da qualidade vocálica, acentuação, grau de ênfase, posição dentro da palavra, velocidade da fala, tamanho da palavra, entre outros.

Já a escolha pela análise do centroide se deve ao fato de, na análise dos quatro momentos espectrais, proposta por Forrest et al. (1988), o primeiro momento espectral (centroide) ser considerado o mais robusto para análise dos sons fricativos (Silva, 2012; Gruba, 2018). O centroide ou média (centre of gravity), corresponde à média das frequências ponderadas a partir de um conjunto de frequências dadas pelo espectro do ruído fricativo (Forrest et al., 1988).

Esperamos que a partir desse trabalho possamos contribuir para o desenvolvimento de outras pesquisas que aprofundem o tema, bem como incentivar aos profissionais que atuam na avaliação e reabilitação da fala a utilizarem métodos de análises mais objetivos em sua atuação. 


\section{MÉTODOS}

Este estudo é um recorte de uma dissertação de mestrado (Gruba,2018) que realizou uma pesquisa sobre os segmentos fricativos produzidos por um sujeito com trissomia do cromossomo 21 a partir da análise acústica destes segmentos.

O sujeito dessa pesquisa, aqui denominado SM, tem 15 anos, é do gênero masculino, analfabeto, e reside na cidade de Brumado, no estado da Bahia. SM foi selecionado para compor esta pesquisa devido ao fato de nunca ter sido submetido à intervenção fonoaudiológica.

A participação de SM nessa pesquisa se deu a partir da aprovação e consentimento de sua família. Esse estudo faz parte de um projeto guarda-chuva denominado Núcleo Saber Down, sediado na Universidade Estadual do Sudoeste da Bahia e aprovado pelo Comitê de Ética e Pesquisa (CAAE:04853012.6.0000.0055).

O corpus foi constituído por palavras reais e de fácil conhecimento pelo sujeito pesquisado. Após a definição do corpus, foram selecionadas figuras que representassem as palavras definidas e que continham as fricativas labiodentais, alveolares e palatoalveolares (surdas e sonoras), em posição de onset silábico, inicial (OI) e medial (OM), nos contextos das vogais [a], [ع], [e], [i], [o], [o] e [u].

Após seleção das figuras, foi realizado um teste de validação, que consistiu na nomeação dessas imagens por SM. Através desse procedimento, foi possível avaliar se o sujeito avaliado tinha dificuldade na identificação das imagens.

Após o teste, observarmos que algumas figuras foram de difícil identificação. Por este motivo, algumas foram reajustadas ou substituídas por imagens mais claras e maiores, e dispostas novamente em forma de slides para projeção, mediante software Power Point 2010.

Antes de realizarmos a gravação da fala em cabine acústica, SM foi submetido à uma análise dos órgãos fonoarticulatórios e a uma gravação em vídeo da fala dele para posterior análise dos movimentos articulatórios realizados por ele durante a nomeação. Essa gravação foi realizada em ambiente fechado, SM foi posicionado de frente para a câmera de vídeo, Panasonic Full HD 28mm 
Wide. Para apresentação das imagens do corpus, utilizamos um tablet com tela de 10 ". Ao longo da gravação eram realizadas intervenções dos pesquisadores de forma a incitar a produção oral de SM.

Após a gravação do vídeo, realizamos a gravação da fala em cabine acústica, por meio de um computador Macbook Pro. Para gravação, utilizamos o programa Audacity, em uma taxa de amostragem de $44,1 \mathrm{KHz}$. As figuras foram apresentadas em uma tela de computador 13", dispostas em slides no modo de tela cheia. O computador foi colocado à altura dos olhos de SM para facilitar a visualização das imagens. Durante a gravação, quando necessário, eram realizadas intervenções do pesquisador, de forma a auxiliar o sujeito na identificação das figuras.

Para garantir uma boa amostra dos dados, foram realizadas três repetições. A cada término de uma repetição, era realizada uma pausa, de forma a não fadigar o paciente. $O$ tempo de gravação foi muito variável, pois na primeira repetição foi necessário um maior número de intervenções para incitar a identificação da figura. As intervenções foram diminuídas na segunda e terceira repetições.

Para a análise acústica foram mensurados o valor do centroide e da duração relativa dos segmentos fricativos, por meio do Praat (Boersma; Weeninck, 2006). Para obtermos a DR, primeiramente, realizamos a identificação e etiquetagem das palavras e das fricativas por meio da ferramenta TextGrid do programa de análise acústica (ver figura 12). Em seguida, os valores de duração das palavras e dos segmentos fricativos foram tabulados. A obtenção da DR se deu pela divisão do valor obtido na duração do segmento pelo valor da duração da palavra. $\mathrm{O}$ valor obtido nessa divisão foi multiplicado por 100 para que obtivéssemos a porcentagem (\%) que o segmento avaliado ocupa dentro da palavra em que está inserido.

Os valores do centroide foram obtidos automaticamente pelo Praat (Boersma; Weenink, 2006), a partir do spectrum da fricativa que é dado pela FFT (Fast Fourier Transform). Para o cálculo desse momento espectral, seguimos o que foi proposto por Silva (2012) e extraímos os valores a partir de uma janela de 10 milissegundos de duração, retirada da porção central do segmento 
alvo. A escolha por analisar a fricativa em sua porção medial se deve ao fato de a produção ser mais estável nessa região.

Após análise, os dados foram tabulados separadamente em Excel e, posteriormente, retiramos a média das três repetições dos segmentos fricativos avaliados.

A análise do centroide requer que seja feita uma filtragem das fricativas sonoras. Para isso, utilizamos o filtro Pass Hann Band nas fricativas sonoras, tentando dessa forma evitar que o vozeamento interferisse nos valores espectrais desses segmentos.

Para análise dos órgãos fonoarticulatórios (OFAs) utilizamos como parâmetro partes do protocolo de avaliação miofuncional orofacial intitulado Protocolo MBGR. Esse protocolo foi desenvolvido por Genaro et al. (2009) a partir da análise de diversos protocolos utilizados para a avaliação da motricidade orofacial, sendo assim, um dos mais completos utilizados ultimamente na fonoaudiologia. Os resultados obtidos foram anotados para que pudéssemos compará-los aos demais.

Após obtenção dos dados acústicos e fonoarticulatórios, comparamos os achados de ambas as avaliações. A análise e descrição dos dados e a discussão dos resultados serão expostas a seguir.

\section{AVALIAÇÃO MIOFUNCIONAL, ANÁLISE ACÚSTICA: PISTAS PARA UM DIAGNÓSTICO DE APRAXIA}

Nesta seção, apresentamos os resultados obtidos na avaliação fonoaudiológica da motricidade orofacial e na análise do centroide e da duração relativa das fricativas. As análises deixam clara a estreita relação entre as características oromiofuncionais do sujeito investigado e as características acústicas e articulatórias dos segmentos fricativos por SM produzidos. Em seu conjunto, a análise miofuncional e os resultados acústicos possibilitaram à hipótese que acenou para o diagnóstico diferencial de existência de Apraxia de Fala. Salientamos que embora as pessoas com sD, em geral, apresentem problemas de fala, isso não significa que elas tenham apraxia de fala, como ocorre com o sujeito por nós investigado. 


\subsection{Avaliação miofuncional orofacial e da fala}

Iniciamos com a apresentação da avaliação miofuncional de SM. A análise demonstrou que o sujeito examinado apresenta mordida aberta anterior, com dentes incisivos superiores em posição overjet de quatro milímetros e presença de mordida cruzada para o lado esquerdo durante a oclusão.

Quanto aos lábios de SM, são entreabertos ao repouso, com diminuição do tônus e mobilidade dessas estruturas. Os inferiores, em específico, são evertidos e volumosos.

$\mathrm{Na}$ avaliação da língua, SM apresenta déficit no tônus, mobilidade e praxia motora. Apresenta língua volumosa, rebaixada na cavidade oral e apoiada nos lábios inferiores ao repouso.

$\mathrm{Na}$ avaliação das bochechas, SM apresentou uma leve assimetria, com diminuição do tônus e da mobilidade dessas estruturas.

$\mathrm{Na}$ observação da fala, por meio da análise oitiva e dos movimentos articulatórios, observamos que SM apresenta ausência da produção dos segmentos líquidos e dos clusters consonantais. Na produção dos segmentos alveolares, observamos que SM apresenta interposição da língua entre os dentes, com algumas distorções nesses sons (Figura 1).

Figura 1 - SM com a língua protruída ao produzir a fricativa $[z]$ na palavra "zorro"

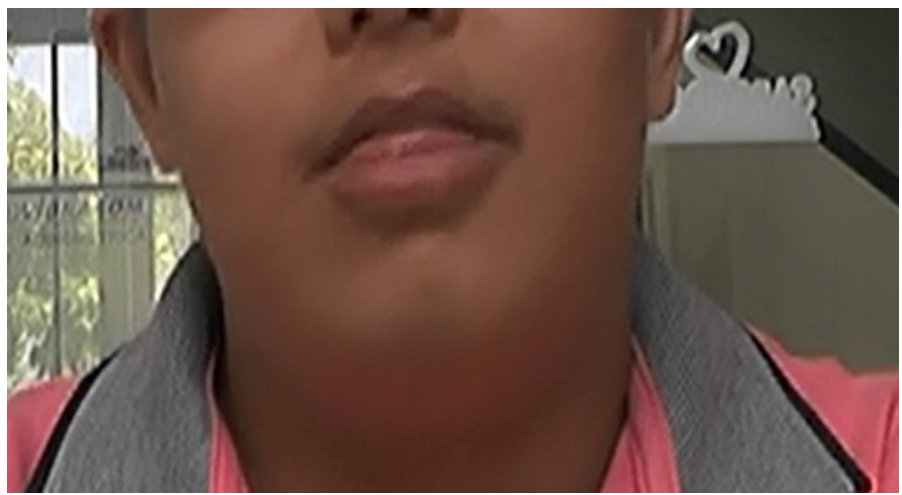

Fonte: Banco de Dados Núcleo Saber Down (Todos os direitos reservados). 
Além das características articulatórias encontradas, observamos que SM apresenta grande variabilidade na produção de todos os fones, sendo eles em alguns momentos produzidos corretamente e outros não. Observamos também que palavras com 3 sílabas ou mais geram maior dificuldade articulatória para SM, havendo omissão de segmentos e/ou de sílabas quando da produção de palavras mais extensas.

Essa dificuldade e variabilidade na produção dos segmentos pode ser verificada na figura 2. Observe na figura 2 que na produção de SM para a palavra árvore, na análise da oitiva, temos a impressão de que SM realiza a

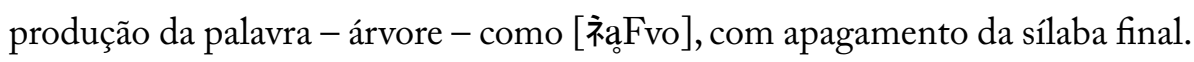
Além disso, na análise acústica é possível notar alterações na produção dos segmentos. Por exemplo, a vogal [a] apresenta um ensurdecimento parcial, as consoantes apresentam ondas quase periódicas que caracterizam uma produção vocálica e não um ruído fricativo, e a produção do segmento [o], SM realiza de forma mais prolongada e há perda de energia ao longo da sua emissão.

Figura 2 - Produção da palavra árvore por SM demonstrando desvozeamento parcial da vogal [a], alterações nos espectros das consoantes e perda de energia na emissão da vogal [o]

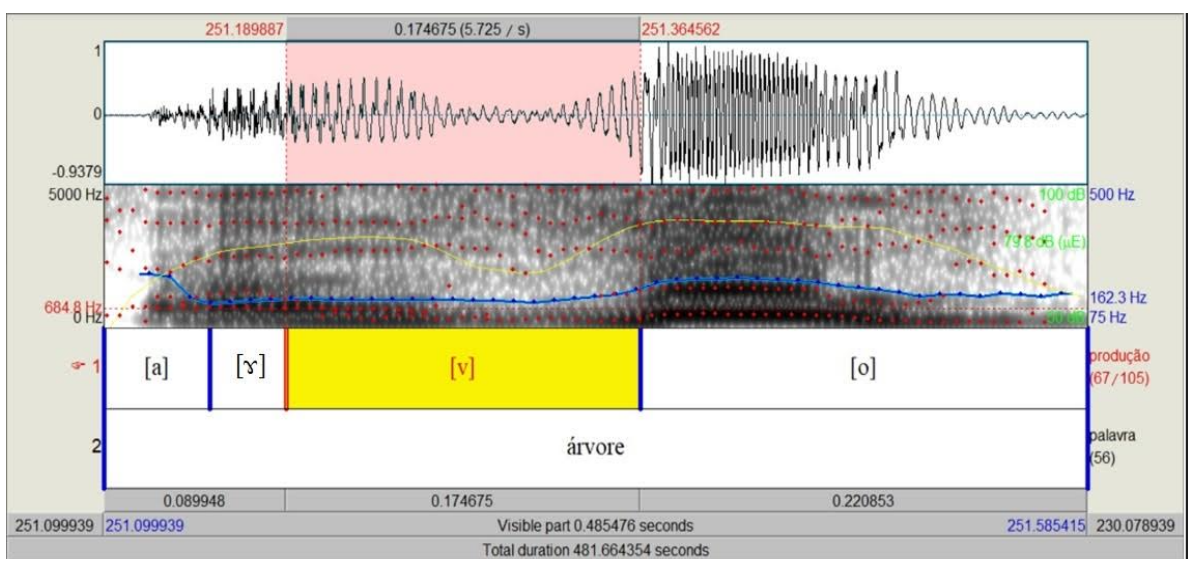

Fonte: Elaboração própria.

Oliveira (2011) ressalta em seu estudo que pessoas com sD apresentam alterações na produção dos segmentos vocálicos. Ressalto que não descartamos que a produção das vogais de SM possa conter alterações, principalmente por já ser 
possível notar um ensurdecimento e perda de energia na produção destes segmentos, como exposto na figura 2. Contudo, nosso estudo teve por objetivo analisar as fricativas; não fizemos a análise aprofundada das vogais produzidas por SM.

Além das alterações encontradas acima na análise articulatória e da oitiva, observamos outras alterações na produção da fala de SM, dentre elas: adição de sílabas como na palavra sabão em que o sujeito avaliado produziu [sa'baxo] (Figura 3), pausas no meio da palavra, prolongamentos de sons, força na produção de alguns sons, variação na produção da palavra em cada uma das três repetições solicitadas. Por exemplo, na realização da palavra "bexiga", na primeira gravação SM produziu [bo'/ige], na segunda, [bo'/ige] e na terceira [po'fige].

Figura 3 - Produção da palavra sabão por SM com pausa no meio da palavra e adição de sílaba

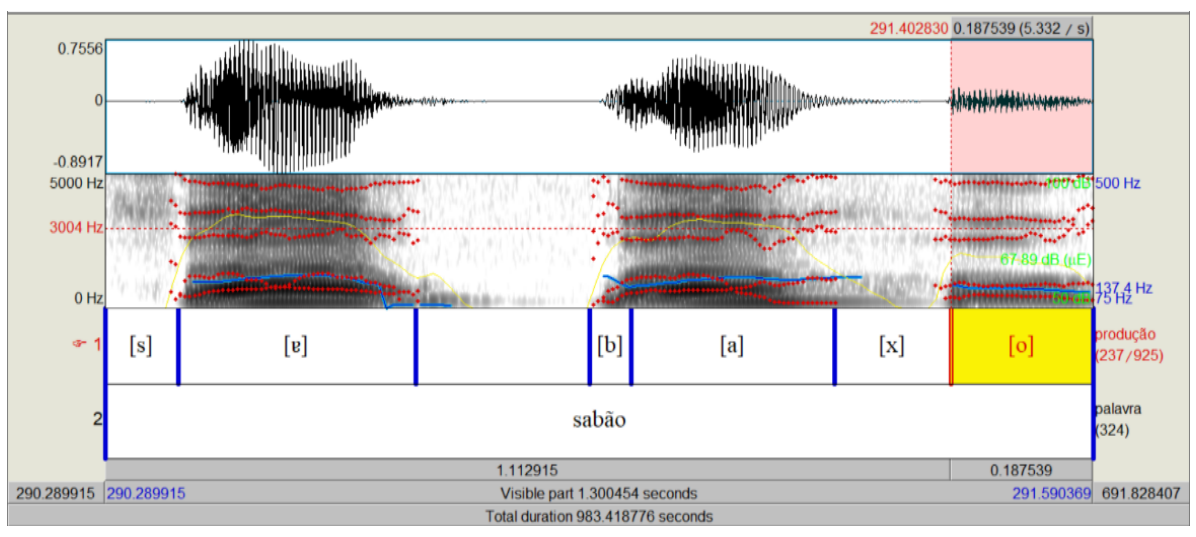

Fonte: Elaboração própria.

A análise articulatória e da oitiva foram relevantes na avaliação e caracterização da fala do nosso sujeito avaliado. Entretanto, ao analisarmos as características acústicas das fricativas, tanto os valores do centroide quanto da duração relativa foram imprescindíveis para um diagnóstico diferencial de transtorno da fala, no caso, apraxia.

\subsection{Análise acústica do Centroide: aspectos auxiliares no diagnóstico das alterações articulatórias e apraxia de fala}

Estudos comprovam que a análise dos quatro momentos espectrais proposta por Forrest et al. (1988) vem demonstrando ser o parâmetro que 
melhor caracteriza as fricativas acusticamente (Jongman; Wayland; Wong, 2000, Jesus, 2001, Silva, 2012, Gruba, 2018). Entretanto, por mais que os quatros momentos espectrais sejam utilizados na descrição acústica dos segmentos fricativos, o primeiro momento espectral, Centroide, vem demonstrando ser o mais robusto na caracterização dessa classe de sons.

$\mathrm{Na}$ análise do centroide da fala de SM, observamos uma grande variação nos dados encontrados, que evidencia muita dificuldade na produção do segmento fricativo, muitas omissões de sílabas e de segmentos, plosivação da fricativa, entre outros.

Dentre os achados na análise acústica, os que mais nos chamaram a atenção foram os valores abaixo de $1000 \mathrm{~Hz}$ para as fricativas sonoras, enquanto esperávamos valores acima de $3000 \mathrm{~Hz}$. Os valores mais baixos para a posição de onset medial, na maioria das vezes abaixo de $3000 \mathrm{~Hz}$, em relação ao onset inicial, com a maioria dos valores acima de $4000 \mathrm{~Hz}$. Outros dados que chamaram a atenção referem-se aos valores semelhantes das fricativas palatoalveolar e alveolar, chegando a mais de $5000 \mathrm{~Hz}$ em ambas, enquanto a literatura registra valores do centroide das palatoalveolares mais baixos que os valores das fricativas alveolares (Jesus, 2001, Silva, 2012). (Cf. Gráfico 1).

Gráfico 1 - Valores médios do Centroide das fricativas em onset inicial e medial

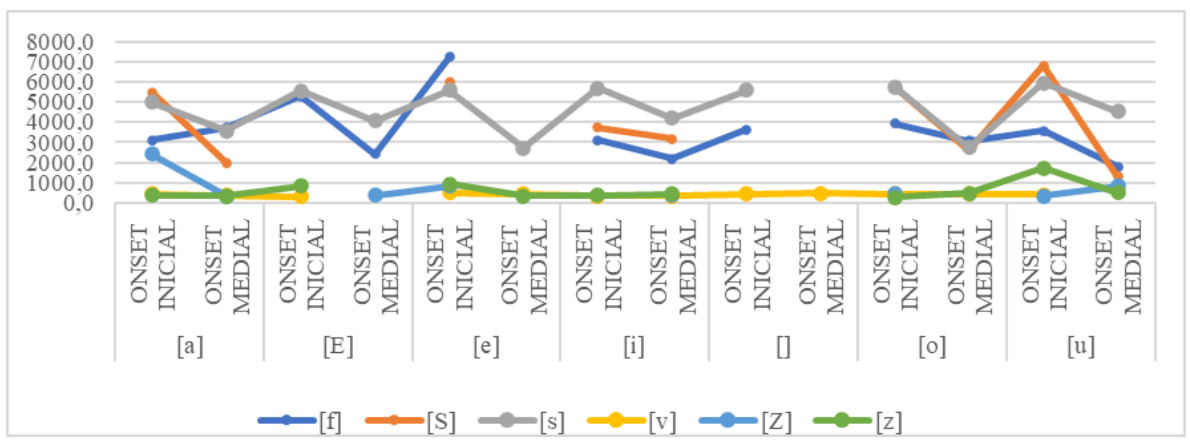

1.[S] representa a fricativa palatoalveolar surda [C].

2. [Z] representa a fricativa palatoalveolar sonora [3].

Fonte: Elaboração própria.

Observe no gráfico 1 que há falhas presentes nos traçados que se referem aos valores do Centroide encontrados para cada segmento fricativo. Isso se deve ao fato de SM não ter produzido a fricativa na posição silábica e contexto 
vocálico, como demonstrado na parte inferior do gráfico. Por exemplo, observe a fricativa [s] (cinza), ela não possui marcação na posição de onset medial em contexto da vogal [o], dando assim uma descontinuidade ao traçado do gráfico. Esta descontinuidade no gráfico é importante e deve ser considerada, pois nos serve como pista da inconsistência da fala de SM.

Além da inconsistência da fala, demonstrada no gráfico 1 , os valores do centroide das fricativas sonoras são muito inferiores aos das fricativas surdas. Observe que os valores do centroide das fricativas [v], [z] e [3] não ultrapassaram, na maioria das vezes, a faixa de $1000 \mathrm{~Hz}$, exceto a fricativa [3] em contexto da vogal [a] na posição de onset inicial e a fricativa [z] em contexto da vogal $[\mathrm{u}]$ na mesma posição. Ao analisarmos esses segmentos com valores mais altos na análise acústica, o que percebemos é que isso se deve à dessonorização parcial do segmento fricativo avaliado, o que gerou valores mais altos do centroide, pois ao selecionarmos a janela de $10 \mathrm{~ms}$ na posição central, acabamos por selecionar uma porção dessonorizada, o que é pista de uma inconsistência que pode ser gerada por uma falta de controle de pregas vocais (Figura 4).

Figura 4 - Dessonorização parcial do segmento [z] na produção [z¥us] referente a palavra Jesus

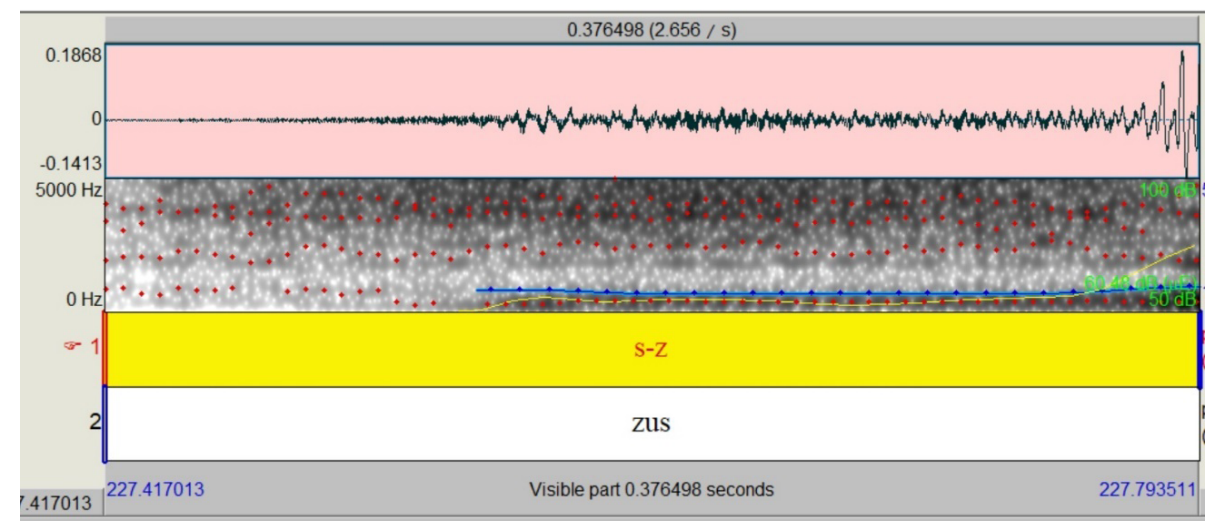

Fonte: Elaboração própria.

Em relação aos valores abaixo de $1000 \mathrm{~Hz}$ para as fricativas sonoras, os resultados divergem daqueles encontrados na literatura para estes segmentos (Jesus, 2001; Silva, 2012). Ao analisarmos o formato de onda da fricativa sonora produzida por SM, notamos que tal produção diverge muito da esperada 
para um ruído fricativo. Uma das características do ruído fricativo é o formato de onda aperiódica, diferente da onda periódica encontrada nas vogais (Kent; Read, 2015; Barbosa; Madureira, 2015).

Se compararmos na análise acústica a produção de um som fricativo surdo e um sonoro produzido por SM, levando em consideração o mesmo ponto articulatório e posicionamento dentro da palavra, é evidente a diferença do formato de onda encontrada no segmento surdo e no segmento sonoro (Figura 5). No caso da produção da fala de SM, as fricativas surdas, em sua maioria, exceto em algumas produções de fricativas na posição de onset medial, apresentaram formato de onda irregular, característico do ruído fricativo. Entretanto, se observarmos o formato de onda da fricativa sonora, percebemos uma onda quase periódica, lembrando o formato de onda de um som vocálico. O mais interessante é que mesmo não apresentado uma produção típica do ruído fricativo sonoro na análise acústica, na análise da oitiva, temos a impressão de o segmento ter sido produzido prototipicamente. Essa impressão pode gerar equívocos de análise do problema de fala do paciente, pelo fonoaudiólogo, o que por seu turno, poderia gerar equívoco quanto ao diagnóstico e terapêutica. Equívoco este que seria evitado, se o profissional partir de uma análise mais objetiva como a possibilitada pela acústica

Figura 5 - Comparação entre uma onda quase periódica na produção da fricativa sonora [v] na palavra vaca e uma onda aperiódica da fricativa [f] na palavra folha

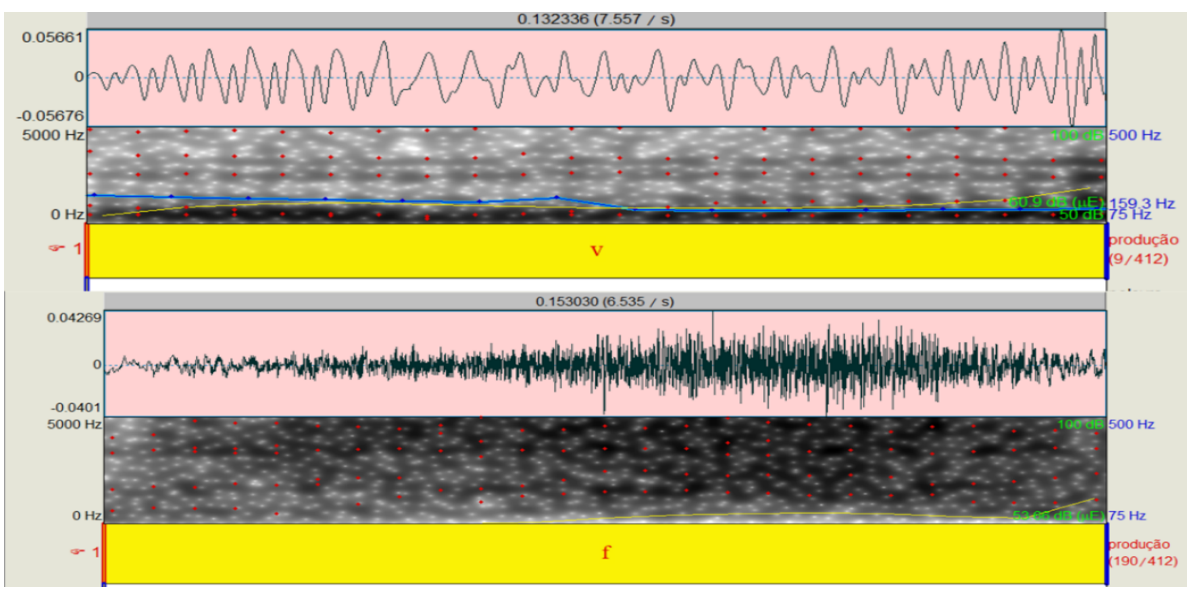

Fonte: Elaboração própria. 
Quanto à posição das fricativas dentro da palavra, no geral, as fricativas sonoras em posição de onset medial tendem a apresentar valores inferiores aos das fricativas surdas em onset inicial, como mencionado anteriormente. Acreditamos que isto se deva ao fato de que SM tende a trazer a sonoridade dos segmentos adjacentes para a fricativa produzida em posição medial, o que pode justificar os valores mais baixos, pois como vimos no parágrafo anterior, SM tem uma dificuldade na produção dos segmentos sonoros, o que ocasiona a queda dos valores do centroide nesses sons (cf. Figura 6).

Figura 6 - Imagem do Praat com a presença de pitch na produção do [f]

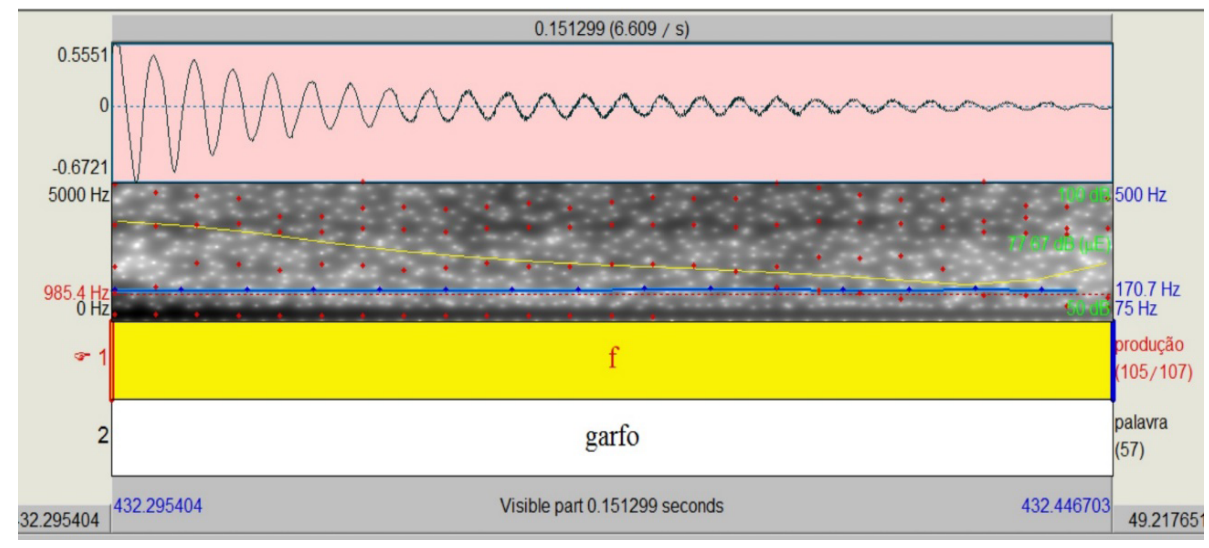

Fonte: Elaboração própria.

Já no caso das fricativas alveolar e palatoalveolar em onset inicial, percebemos que ambas apresentaram valores muito próximos, a maioria acima de $5000 \mathrm{~Hz}$. Em alguns momentos, a fricativa [S] chegou a apresentar valores mais altos, $6536 \mathrm{~Hz}$, que os da fricativa [s], $5562 \mathrm{~Hz}$ (Figura 7). 
Figura 7 - Espectro de Fourier retirado da região central das fricativas [s] (rosa) e [S] (cinza).

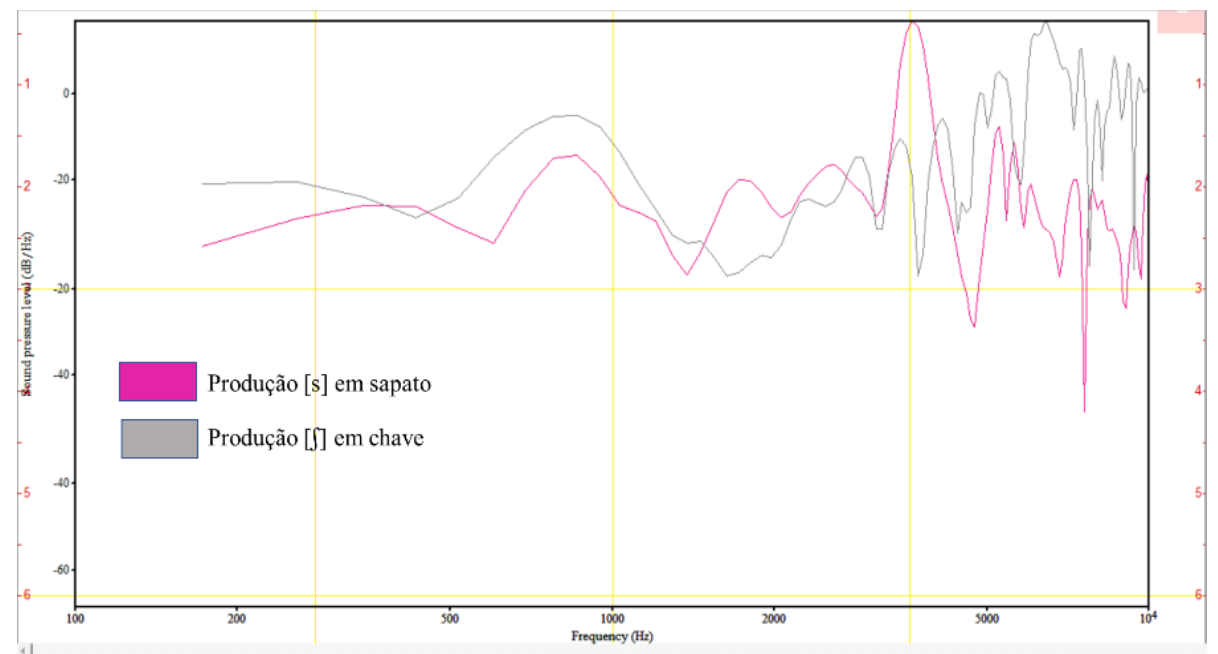

Fonte: Elaboração própria.

Acreditamos que esses valores aproximados para as fricativas alveolar e palatoalveolar surda se devam ao fato de SM realizar uma anteriorização da língua durante ao produzir tais sons, principalmente durante a emissão da fricativa palatoalveolar. $\mathrm{O}$ que pode justificar o valor mais alto que o obtido com a fricativa alveolar surda (Figura 7).

Figura 7 - Representação da anteriorização de língua no segmento [s] na produção da palavra xícara

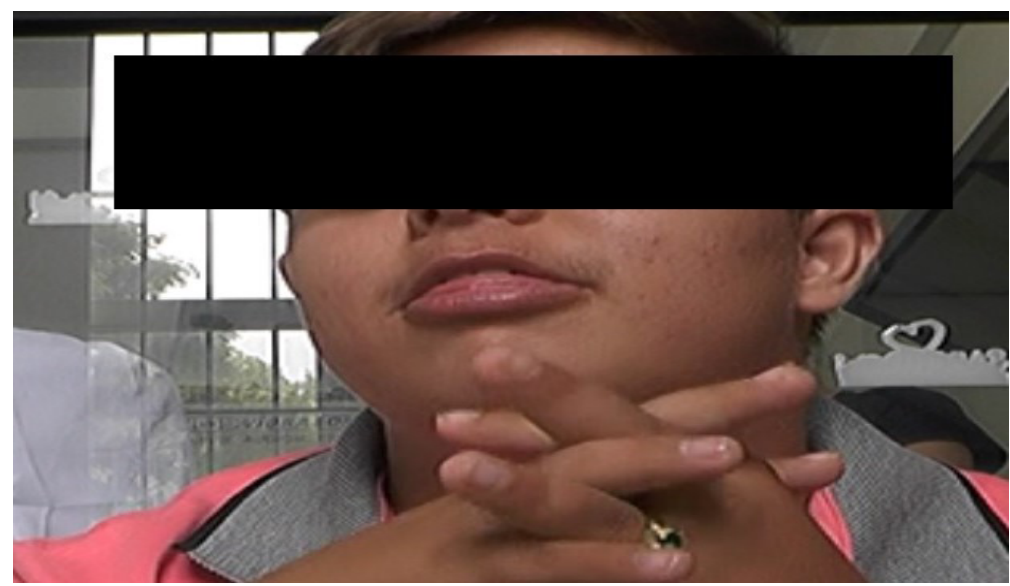

Fonte: Núcleo Saber Down (Todos os direitos reservados). 
Os achados até então expostos neste estudo da fala de SM corroboram os achados da literatura para o diagnóstico de apraxia de fala. De acordo com Kumin (2006) e Rupela, Velleman e Andrianopoulos (2016), além das alterações nas habilidades do planejamento motor oral, ou seja, das dificuldades no sequenciamento e combinação dos sons dentro das palavras, frases e sentenças. Podemos citar ainda como característica de apraxia a redução da precisão articulatória, inconsistência nos movimentos motores dos OFAs, dificuldade nas tarefas de diadococinesia oral, ou seja, em realizar movimentos rápidos alternadamente, dificuldades na produção de palavras, com exclusão de sons e sílabas, dificuldade em coordenar a força na produção dos sons, dificuldade na imitação e produção das palavras, mesmo que familiares etc. (Kumin, 2006; Rupela; Velleman; Andrianopoulos, 2016). Salientamos que em teste de percepção aplicados a 10 juízes estratificados a partir do sexo e grau de escolaridade, o nível de recuperação da fricativa produzida por SM foi baixo, o que mostra que as alterações na sua fala comprometem a comunicação, em função do grau de ininteligibilidade.

A seguir, apresentaremos os achados na análise acústica da duração relativa dos segmentos fricativos produzidos por SM, parâmetro acústico robusto para análise de fricativa e que se mostrou com ferramenta importante para o diagnóstico de apraxia no sujeito pesquisado.

\subsection{Análise da duração relativa: contribuição para um diagnóstico diferen- cial da apraxia de fala}

A duração é um parâmetro acústico que diferencia a classe de sons das fricativas de outras classes, como a das oclusivas e das africadas. Além disso, a duração também tem demonstrado ser um parâmetro acústico importante na diferenciação das fricativas surdas das sonoras (Kent; Read, 2015, Silva, 2012, Haupt, 2008, Jesus, 2001).

$\mathrm{Na}$ análise da duração relativa das fricativas produzidas por SM, no geral, o que encontramos foram resultados muito variáveis. Diferente do exposto na literatura (Kent; Read, 2015,S, 2012, Haupt, 2008, Jesus, 2001), os valores 
da DR obtidos na análise da fala de SM não permitiram diferenciar as fricativas surdas das sonoras. Observe na Tabela 1 que os valores da DR são muito variáveis na fala de SM, ora apresentando valores mais altos para as fricativas surdas e ora para as sonoras.

Tabela 1 - Média dos valores obtidos no cálculo da duração relativa dos segmentos fricativos produzidos por SM

\begin{tabular}{|c|c|c|c|c|c|}
\hline \multicolumn{6}{|c|}{$\begin{array}{l}\text { MÉDIA DOS VALORES DA DURAÇÃO RELATIVA DOS } \\
\text { SEGMENTOS FRICATIVOS \% }\end{array}$} \\
\hline \multirow[b]{2}{*}{$\begin{array}{c}\text { PONTO } \\
\text { DE ARTICU- } \\
\text { LAÇÃO }\end{array}$} & \multirow[b]{2}{*}{$\begin{array}{l}\text { CONTEXTO } \\
\text { VOCÁLICO }\end{array}$} & \multicolumn{2}{|c|}{ SURDA } & \multicolumn{2}{|c|}{ SONORA } \\
\hline & & $\begin{array}{l}\text { ONSET } \\
\text { INICIAL }\end{array}$ & $\begin{array}{l}\text { ONSET } \\
\text { MEDIAL }\end{array}$ & $\begin{array}{l}\text { ONSET } \\
\text { INICIAL }\end{array}$ & $\begin{array}{l}\text { ONSET } \\
\text { MEDIAL }\end{array}$ \\
\hline \multirow{7}{*}{ Alveolar } & {$[\mathrm{a}]$} & 16,88 & 22,53 & 12,54 & 18,65 \\
\hline & {$[\varepsilon]$} & 18,65 & 16,66 & 0,00 & 0,00 \\
\hline & {$[\mathrm{e}]$} & 37,63 & 25,94 & 35,02 & 13,38 \\
\hline & [i] & 22,78 & 18,21 & 11,82 & 12,73 \\
\hline & {$[0]$} & 17,82 & 16,17 & 28,01 & 17,95 \\
\hline & {$[0]$} & 18,44 & 0,00 & 0,00 & 0,00 \\
\hline & {$[\mathrm{u}]$} & 17,00 & 22,88 & 23,77 & 20,90 \\
\hline \multirow{7}{*}{ Labiodental } & {$[\mathrm{a}]$} & 17,00 & 17,24 & 20,32 & 12,29 \\
\hline & {$[\varepsilon]$} & 15,31 & 25,82 & 12,93 & 11,86 \\
\hline & {$[\mathrm{e}]$} & 30,38 & 0,00 & 20,89 & 0,00 \\
\hline & [i] & 24,35 & 25,09 & 24,89 & 13,48 \\
\hline & {$[0]$} & 16,41 & 16,40 & 26,28 & 12,21 \\
\hline & {$[0]$} & 16,92 & 0,00 & 5,43 & 6,82 \\
\hline & {$[\mathrm{u}]$} & 16,43 & 13,55 & 28,70 & 0,00 \\
\hline \multirow{7}{*}{ palatoalveolar } & {$[\mathrm{a}]$} & 11,35 & 19,84 & 15,96 & 16,73 \\
\hline & {$[\varepsilon]$} & 0,00 & 0,00 & 0,00 & 14,51 \\
\hline & {$[\mathrm{e}]$} & 23,40 & 0,00 & 16,50 & 0,00 \\
\hline & [i] & 13,18 & 11,29 & 0,00 & 11,40 \\
\hline & [o] & 5,85 & 17,75 & 13,91 & 0,00 \\
\hline & {$[0]$} & 0,00 & 0,00 & 0,00 & 0,00 \\
\hline & {$[\mathrm{u}]$} & 17,75 & 13,89 & 19,33 & 21,77 \\
\hline
\end{tabular}

Fonte: Elaboração própria. 
De acordo com Barbosa e Madureira (2015), o contraste existente entre as fricativas - a duração menor para as fricativas sonoras em relação às surdas - pode ser considerado um aspecto universal. Segundo os autores, a menor duração das fricativas sonoras se deve ao gasto de energia na vibração das pregas vocais. Ao produzirmos a fricativa sonora, o fluxo de ar que sai dos pulmões deverá ser suficiente para vibrar as pregas vocais e ainda garantir velocidade suficiente para gerar a turbulência necessária à fricção. Dessa forma, ao produzir uma fricativa sonora, devido à diminuição do fluxo de ar, estes segmentos apresentariam duração mais baixa.

No entanto, como vimos na análise dos momentos espectrais, SM apresenta alterações na produção dos segmentos fricativos sonoros, não conseguindo realizar a produção prototípica destes segmentos. Acreditamos que SM apresente duração relativa mais alta na produção dos segmentos sonoros, em virtude dum prolongamento deste som como tentativa de alcançar uma produção correta.

Quanto aos valores da DR, Silva (2012) encontrou valores acima de $25 \%$ para as labiodentais surdas e acima de $17 \%$ para as sonoras. Já para as alveolares, a autora encontrou valores acima de $28 \%$ para a fricativa [s] e acima de $19 \%$ para a fricativa [z] e para as palatoalveolares, a fricativa surda apresentou valores de DR acima de $25 \%$ e a sonora acima de $20 \%$. Outro fator observado pela pesquisadora é que a duração relativa das fricativas costuma ser maior em posição de onset inicial comparado à posição medial.

Entretanto, os resultados encontrados por nós não se assemelham aos achados por Silva (2012). Na fala de SM, notamos que em vários momentos, na posição de onset medial, a DR foi maior que a posição de onset inicial, tanto para as fricativas surdas quanto para as sonoras.

Outro fator observado que diverge do estudo de Silva (2012) foram os valores baixos encontrados para a DR das fricativas produzidas por SM. Os valores da duração relativa obtidos na análise da fala de SM, em sua maioria, ficaram abaixo de $25 \%$. Se observarmos melhor, nota-se que grande parte dos valores sequer ultrapassaram os $17 \%$, que foi o menor valor da DR obtido na literatura (SILVA, 2012).

Acreditamos que os valores baixos da duração relativa das fricativas se devam à hipotonia global apresentada por SM. O tônus rebaixado da musculatura orofacial, bem como da musculatura respiratória pode comprometer a produção prolongada do segmento fricativo. Contudo, podemos nos questionar o porquê 
de SM produzir o segmento fricativo sonoro com maior duração. A resposta para este questionamento pode estar ligada ao fato de SM não realizar as fricativas sonoras de forma prototípica, o que pode ter gerado esse resultado.

Outra justificativa para essas alterações na DR dos segmentos fricativos da fala de SM pode ser encontrada nos estudos de Berti (2006), que observou que crianças com queixas fonoaudiológicas na fala tendem a apresentar uma DR menor dos segmentos fricativos, ou seja, as fricativas produzidas por crianças com dificuldade na fala ocupam uma porção relativamente menor dentro da palavra se comparadas à produção da fala de crianças sem queixas.

A análise da duração relativa também contribuiu para o diagnóstico de apraxia de fala. Ao analisarmos a DR dos segmentos fricativos de cada uma das três repetições das palavras do corpus, observamos em vários momentos uma grande variabilidade na duração. Por exemplo: ao produzir a palavra fogão, na primeira gravação, SM apresentou a DR no valor de 26,01\%. Já na segunda, o segmento fricativo teve a DR de 4,12\%. Na terceira gravação, o valor obtido foi de 10,71\%. A variabilidade é algo esperado, porém há uma queda significativa entre a primeira e as demais produções. Observe que há uma grande variabilidade nos valores apresentados (Gráfico 2).

Gráfico 2- Valores da duração relativa obtidos do segmento [f] da palavra fogão produzido em três repetições (\%)

\section{Valores obtidos da DR para o segmento [f] em três repetições}

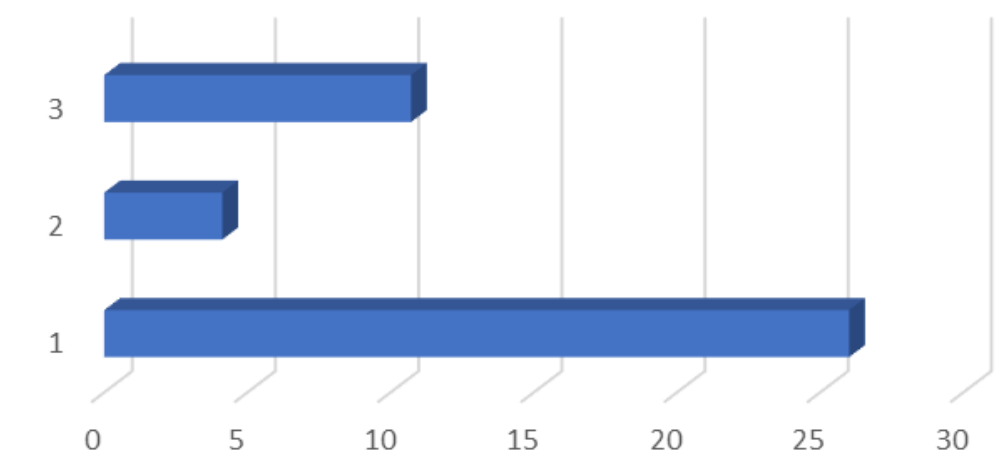

Fonte: Elaboração própria. 
Assim como ocorreu na produção do [f] na palavra fogão, outras produções de segmentos em diferentes palavras apresentaram essa grande variabilidade na duração de cada uma de suas repetições, sendo esta falta de constância na produção repetida de palavras e segmentos uma grande característica da apraxia de fala.

\subsection{Os achados na avaliação de SM e a relação destes com a apraxia de fala}

De acordo com Kumin (2006), podemos inferir que SM apresenta não apenas comprometimento nas habilidades motoras orofaciais que são familiares à pessoa com T21, mas também dificuldades na programação e sequencialização motoras necessárias para a produção dos sons da fala. Os resultados da análise do centroide, bem como os encontrados para a DR das fricativas de SM podem ter relação direta com a imprecisão articulatória que ele apresenta durante a produção devido à hipotonia e alterações na praxia oral. Acreditamos que esta imprecisão pode gerar produções menos articuladas, consequentemente mais rápidas.

Outro ponto observado durante a análise da duração relativa foi que SM realiza o prolongamento do som fricativo em alguns momentos e este prolongamento normalmente vem associado com força durante a produção. De acordo com Souza e Payão (2008), as características como prolongamento dos segmentos, esforço na produção dos sons, entre outros, estão relacionadas ao diagnóstico de Apraxia de Fala. No entanto, no que se refere à SM, ainda é necessário observar e investigar outros aspectos da fala dele, para que possamos fazer tal afirmação.

A seguir, apresentaremos um quadro sintetizando as características acústicas e articulatórias apresentadas por SM com as características da apraxia de fala sugeridas na literatura. 
Quadro 1 - Quadro comparativo entre as características da apraxia de fala encontradas na literatura e as características da fala do sujeito com Down avaliado

\begin{tabular}{|c|c|}
\hline $\begin{array}{l}\text { Características da } \\
\text { Apraxia de Fala }\end{array}$ & Características encontradas na fala de SM \\
\hline $\begin{array}{l}\text { História de atraso no desenvolvi- } \\
\text { mento da fala e da linguagem }\end{array}$ & $\begin{array}{l}\text { SM só começou a produzir algumas palavras } \\
\text { aos } 3 \text { anos, mas fala ininteligível }\end{array}$ \\
\hline $\begin{array}{l}\text { Inconsistência na produção dos } \\
\text { sons da fala }\end{array}$ & $\begin{array}{l}\text { Se analisarmos as três repetições das palavras, } \\
\text { observamos que SM muitas vezes realiza as } \\
\text { produções de forma variável, repetindo de for- } \\
\text { ma diferenciada a mesma palavra ou até mesmo } \\
\text { não produzindo em alguma repetição. } \\
\text { Apresenta variações nos valores da DR das fri- } \\
\text { cativas em cada repetição da palavra. }\end{array}$ \\
\hline $\begin{array}{l}\text { Esforço para achar posturas arti- } \\
\text { culatórias corretas e suas sequên- } \\
\text { cias, podendo ser acompanhadas } \\
\text { por mímicas faciais }\end{array}$ & $\begin{array}{l}\text { Observamos poucas tentativas de SM em se- } \\
\text { guir um modelo de fala nas tentativas de pro- } \\
\text { dução. No entanto, ao produzir algumas pala- } \\
\text { vras, observamos bloqueios, com movimentos } \\
\text { associados e esforço na produção. }\end{array}$ \\
\hline Repertório limitado de fonemas & $\begin{array}{l}\text { SM ainda não consegue produzir grande parte } \\
\text { dos sons da classe das consoantes líquidas e dos } \\
\text { encontros consonantais. }\end{array}$ \\
\hline $\begin{array}{l}\text { Piora da inteligibilidade com o } \\
\text { aumento da complexidade da fala }\end{array}$ & $\begin{array}{l}\text { Observamos uma dificuldade grande de SM } \\
\text { produzir frases ou palavras extensas, principal- } \\
\text { mente quando não pertencem ao seu cotidiano }\end{array}$ \\
\hline $\begin{array}{l}\text { Substituições, omissões, inversões, } \\
\text { adições, repetições, distorções e } \\
\text { prolongamentos dos sons }\end{array}$ & $\begin{array}{l}\text { SM realizou algumas omissões como [zus] } \\
\text { para Jesus, adições como [sa'bar u] para sabãa, } \\
\text { dentre prolongamentos como na produção da } \\
\text { palavra cebola, distorções como as realizadas nas } \\
\text { fricativas em posição de onset medial e nas so- } \\
\text { noras, etc. }\end{array}$ \\
\hline $\begin{array}{l}\text { Dificuldade na combinação e se- } \\
\text { quenciamento dos fonemas, com } \\
\text { falhas na coarticulação }\end{array}$ & $\begin{array}{l}\text { SM apresenta dificuldade na combinação e se- } \\
\text { quenciamento dos fonemas. Por exemplo: SM } \\
\text { fala ['fosku] para fósforo. }\end{array}$ \\
\hline $\begin{array}{l}\text { Dificuldade na produção de pala- } \\
\text { vras não familiares }\end{array}$ & $\begin{array}{l}\text { As palavras pouco familiares não foram produ- } \\
\text { zidas. Por exemplo: ginástica, gigante, asa, etc. }\end{array}$ \\
\hline
\end{tabular}

Fonte: Elaboração própria com base em Kumin (2006), Souza e Payão (2008), Rupela, Velleman e Andrianopoulos (2016) e Carrara (2016). 
Observe que SM apresenta muitas das características expostas na literatura para diagnóstico da apraxia de fala. Mesmo com esses achados ainda precisamos lançar mão de análises como da velocidade da fala, prosódia, imitação, diadococinesia oral, entre outras, e os resultados encontrados nos apontam para a possibilidade de uma suspeita diagnóstica de apraxia que sem a análise acústica empreendida seria impossível. Ratificamos, inclusive, que diante dos achados encontrados, já é possível elaborar uma proposta de intervenção que considera a possibilidade de apraxia.

De acordo com Carrara (2016), no Brasil, o foco de tratamento para pessoas com síndrome de Down tem sido voltado para uma perspectiva motora oral, devido à hipotonia, ou uma abordagem cognitiva, com foco na estimulação da linguagem. Contudo, é preciso lembrar que ao estimular a fala, o fonoaudiólogo está ampliando e muito o desenvolvimento da linguagem da criança, pois lhe dá maiores oportunidades de comunicação.

Considerando isso, ao elaborarmos um planejamento terapêutico para $\mathrm{SM}$, tivemos que considerar os déficits apresentados por ele. No entanto, não podemos esquecer que alguns padrões de erros na fala tais como simplificação da estrutura silábica, supressão de consoante final e/ou inicial, redução de cluster e plosivação, são também analisados em uma perspectiva linguística-fonológica. Porém, a reabilitação motora não deve ser descartada, pelo contrário, devemos pensar que diante de tantas alterações miofuncionais orofaciais, esse sujeito com Down também necessita desse trabalho de percepção da posição dos órgãos fonoarticulatórios, visando uma maior conscientização do mecanismo de fala (Carrara, 2016).

No Quadro 2 apresentamos uma síntese de estratégias terapêuticas adotadas para melhora da fala de SM. 
Quadro 2 - Proposta de intervenção para o quadro apresentado por SM

\begin{tabular}{|c|c|c|}
\hline Foco & Objetivo & Atividades realizadas \\
\hline 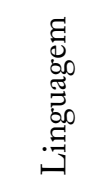 & Adequar o vocabulário & $\begin{array}{l}\text { - Estimulação por meio de atividades com } \\
\text { histórias, separação de campos semânticos, } \\
\text { jogos, etc. } \\
\text { - Orientações aos familiares. }\end{array}$ \\
\hline 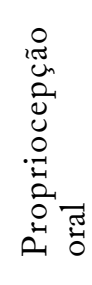 & $\begin{array}{l}\text { Adequar a sensibilidade } \\
\text { tátil e proprioceptiva dos } \\
\text { OFAs }\end{array}$ & $\begin{array}{l}\text { - Uso do massageador facial extra e intra oral } \\
\text { (com auxílio da espátula); } \\
\text { - Uso de estímulos térmicos intra e extra oral; } \\
\text { - Uso de estímulos gustativos (doce e azedo); } \\
\text { - Estimulação digital. }\end{array}$ \\
\hline $\begin{array}{l}\pi \\
\stackrel{\pi}{0} \\
\stackrel{0}{0}\end{array}$ & $\begin{array}{l}\text { Adequar tônus e mobili- } \\
\text { dade dos OFAs }\end{array}$ & $\begin{array}{l}\text { - Exercícios isotônicos; } \\
\text { - Exercícios isométricos; } \\
\text { - Exercícios isocinéticos; } \\
\text { - Aplicação da bandagem elástica. }\end{array}$ \\
\hline 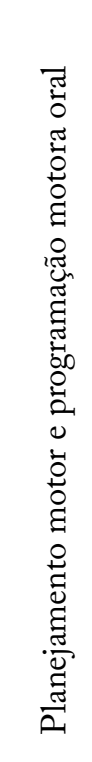 & $\begin{array}{l}\text { Estimular e adequar o } \\
\text { planejamento motor e a } \\
\text { programação motora oral }\end{array}$ & $\begin{array}{l}\text { - Seleção dos sons alvos; } \\
\text { - Atenção, detecção e identificação do som alvo } \\
\text { selecionado; } \\
\text { - Posicionamento de OFAs com auxílio de pis- } \\
\text { tas táteis, cinestésicas e gustativas; } \\
\text { - Uso da ferramenta de feedback visual (exercí- } \\
\text { cios realizados em frente ao espelho); } \\
\text { - Reforçamento da produção correta do som; } \\
\text { - Sequenciamento de fonemas; } \\
\text { - Estimulação das praxias orais associada a sons; } \\
\text { - Exercícios de repetição com o som alvo esta- } \\
\text { belecido; } \\
\text { - Orientações aos familiares para que as ativida- } \\
\text { des sejam realizadas diariamente. }\end{array}$ \\
\hline
\end{tabular}

Fonte: Elaboração própria baseada em Kumin (2006), Souza e Payão (2008), Giannecchini, Yucubian-Fernandes e Maximino (2016), Alves et al. (2016) e Carrara (2016). 


\section{CONSIDERAÇÕES FINAIS}

A proposta deste capítulo era demonstrar a contribuição que a fonética acústica pode oferecer à fonoaudiologia, como, por exemplo, nos casos de eventuais alterações da produção da fala de pessoas com T21 que possam estar relacionadas à apraxia. Analisamos dados de fricativas produzidas por um paciente com Down, no intuito de evidenciar tal contribuição da fonética ao fonoaudiólogo.

Considerando os nossos achados, observamos que as dificuldades apresentadas por SM na produção da fala possuem correlação direta com as especificidades do trato vocal apresentadas por ele. Contudo, não descartamos que SM apresente alterações fonológicas, uma vez que as alterações miofuncionais orofaciais não demonstram serem as únicas causadoras das alterações da fala. Os resultados aqui encontrados evidenciam que SM apresenta imprecisão e inconsistência articulatória, ambas decorrentes de uma possível dificuldade no planejamento motor oral. Esta dificuldade pode ser visualizada a partir da dificuldade que SM teve em realizar a repetição das palavras do corpus, da variabilidade nos resultados apresentados, da dificuldade em realizar a produção das fricativas sonoras, da dificuldade em dissociar a produção da fricativa dos demais segmentos etc.

Os resultados por ora apresentados confirmam a nossa hipótese de que as alterações miofuncionais orofaciais apresentadas pelo sujeito da nossa pesquisa podem interferir nas características acústicas das fricativas por ele produzidas e que a análise acústica da fala contribui para uma avaliação mais objetiva dentro da prática fonoaudiológica, demonstrando que apenas a análise de oitiva não é suficiente para um fechamento diagnóstico. A análise acústica conduzida nos mostra que uma prática fonoaudiológica pautada em princípios teóricos e metodológicos da Fonética Acústica pode contribuir inclusive para suspeita de diagnósticos diferenciais como, por exemplo, os de apraxia de fala, bem como para o desenvolvimento de uma terapêutica mais precisa. 


\section{REFERÊNCIAS}

ALVES, G. A. S. et al. Aspectos da fala na síndrome de Down. In: DELGADO, I. C. et al. Contribuições da Fonoaudiologia na síndrome de Down. Ribeirão Preto: Book Toy, 2016, p. 191-206.

BARBOSA, P. A.; MADUREIRA, S. Manual de fonética acústica experimental: aplicações a dados do português. São Paulo: Cortez: 2015.

BERTI, L.C. Aquisição incompleta dos contrastes entre /s/ e /S/ em crianças falantes do português brasileiro. Tese (Doutorado em Linguística) - Universidade Estadual de Campinas. 2006. Disponível em: http://www.bibliotecadigital. unicamp.br/document/?code=vtls000428837 Acesso em: 10 jul. 2016.

BERTI, L.C.; PAGLIUSO A.; LACAVA, F. Instrumento de avaliação de fala para análise acústica (IAFAC) baseado em critérios linguísticos. Revista Sociedade Brasileira de Fonoaudiologia. Marilia, v. 14, n. 3, 2009. Disponível em: http://www. marilia.unesp.br/Home/Pesquisa/Gpel/Artigos/2009_-_Berti-Pagliuso-Lacava_-_ Instrumento_de_Avaliacao_de_fala.pdf Acesso em: 16 set.2016.

BOERSMA,P.; WEENINK, D.. Praat: doing phonetics by computer [Computer program], 2006. Versão 5.3.51, baixado em 2 Junho de 2013 do site [www.praat.org]

CAMARA JR, J. M. A estrutura da língua portuguesa. 47a edição. Rio de Janeiro: Vozes, 2015 [1970], 124p.

CARRARA, E. Aos interessados no tema de APRAXIA DE FALA NA INFÂNCIA. Compartilho parte de um projeto antigo com apoio do INSTITUTO ALANA: uma aula sobre o tema, com conceitos sobre planejamento. Facebook. 2016. Recuperado de <https://www.facebook.com/wat$\mathrm{ch} /$ ?v=1128681337176574>.

CIRIGLIANO, R.J.R. et al. Um conjunto de 1000 frases foneticamente balanceadas para o português brasileiro obtido utilizando a abordagem de al- 
goritmos genéticos In: XXII Simpósio Brasileiro de Telecomunicações, 5. Anais... Campinas: SBrT, 2005.

CHOMSKY, N.; HALLE, M. The sound pattern of English. Nova York: Harper \& Row, 1968.

FORREST, K. et al. Statistical analysis of word-initial voiceless obstruints: preliminary data. Journal of the Acoustical Society of America. Madison, v. 84, n.1 jul. 1988. Disponível em: https://www.ncbi.nlm.nih.gov/pubmed/3411039 Acesso em 10 jul. 2016.

GIANNECCHINI, T.; YUCUBIAN-FERNANDES, A.; MAXIMINO, L. P. Praxia não verbal na fonoaudiologia: revisão de literatura. Revista CEFAC, São Paulo, v. 18, n. 5, out. 2016. Disponível em: <http://www.scielo.br/scielo. php?script =sci_arttext\&pid=S1516-18462016000501200\&lng=en\&nrm=iso>. Acesso em: 02 jan. 2018.

GRUBA, C.L. Características acústicas e articulatórias na produção de fricativas: pistas para diagnóstico de apraxia e atuação fonoaudiológica em pessoa com síndrome de Down. 2018. 162 p. Dissertação (Mestrado) - Universidade Estadual do Sudoeste da Bahia. Programa de Pós-Graduação em Linguística, Vitória da Conquista-BA, 2018. Disponível em: <http://www2. uesb.br/ppg/ppglin/defesas/2018/Disserta\%C3\%A7\%C3\%A3o\%20-\%20Carolina\%20Lacorte\%20Gruba.pdf>. Acesso em: 30 dez. 2019.

GRUBA, C.L. et al. Análise experimental de fricativas palatoalveolares produzidas por um sujeito com Down. In: XXV CONGRESSO BRASILEIRO DE FONOAUDIOLOGIA E I ENCONTRO DE FONOAUDIOLOGIA DA BAHIA. Anais... Salvador: SBFa, 2017a, p. 9324. Disponível em: http://sbfa.org.br/portal/ anais2017/trabalhos_select.php?id_artigo=9324\&tt=SESS\%C3\%83O\%20DE $\% 20$ CONCORRENTES\%20A\%20PR\%C3\%8AMIO Acesso em: 15 nov. 2017.

GRUBA, C.L. et al. Avaliação espectral de fricativas alveolares produzidas por sujeito com Down: pistas para diagnóstico de apraxia de fala. In: IX SEMINÁRIO 
DE PESQUISA E ESTUDOS LINGUÍSTICOS. Anais... Vitória da Conquista: UESB, 2017b. p. 235-240. Disponível em: http://anais.uesb.br/index.php/ periodicos-uesb-br-spel/article/viewFile/7638/7435. Acesso em: 15 set. 2020

GRUBA, C.L.; OLIVEIRA, M.; PACHECO, V. Estudo piloto da duração relativa de fricativas de um sujeito com síndrome de Down. In: XII COLÓQUIO E V COLÓQUIO INTERNACIONAL DO MUSEU PEDAGÓGICO. Anais...Vitória da Conquista: UESB, 2017, p. 377-382. Disponível em: http://periodicos.uesb.br/index.php/ cmp/article/viewFile/6802/pdf_496 Acesso em: 10 nov. 2017.

HAMILTON, C. Investigation of the articulatory patterns of young adults with Down's syndrome using electropalatography. Down Syndrome Research and Practice. Portsmouth, v.1, n. 1, fev. 1993. Disponível em: https://library.down-syndrome.org/en-us/research-practice/01/1/ investigation-articulatory-patterns-young-adults-down-syndrome-using-electropalatography. Acesso em: 18 abr. 2017.

HAUPT, C. As fricativas [s], [z], [S] e [Z] do português brasileiro. In: Estudos linguísticos XXXVI (1). Florianópolis: UFSC, 2007. Disponível em: http://www.gel.org.br/estudoslinguisticos/edicoesanteriores/4publica-estudos-2007/sistema06/03.PDF Acesso em: 12 nov. 2016.

JAKOBSON, R. FANT, G.; HALLE, M. Preliminaries to Speech Analysis. Cambridge: MIT, 1952

JESUS, L. M.T. Acoustic Phonetics of European Portuguese Fricative Consonants. Tese (Doutorado) - Department of Electronics and Computer Science, University of Southampton, Southampton, 2001. Disponível em: http://sweet. ua.pt/lmtj/lmtj/jesus2000 .pdf Acesso em: 12 nov. 2016.

JONGMAN, A.; WAYLAND, R.; WONG, S. Acoustic characteristics of English 
fricatives. Journal of the Acoustical Society of America. v. 108, n. 3, set. 2000. Disponível em: https://www.ncbi.nlm.nih.gov/pubmed/11008825 Acesso em: 12 nov. 2016.

KENT, R. D.; READ, C. Análise Acústica da Fala. São Paulo: Cortez: 2015.

KUMIN, L. Speech inteligibility and childhood verbal apraxia in children with Down syndrome. Down Syndrome Research and Practice. Maryland, v.10, n.1, jul. 2006. Disponível em: https://www.ncbi.nlm.nih.gov/pubmed/16869369. Acesso em: 18 abr. 2017.

\section{LADEFOGED, P.; MADDIESON, I. The Sounds of the World's Langua-} ges. Oxford: Blackwell Publishers Ltda, 1996.

LAVER,J.Principles of phonetics. Cambridge: Cambridge University Press. 1994.

OLIVEIRA, M.S. Sobre a produção vocálica na Síndrome de Down: Descrição acústica e inferências articulatórias. Tese (Doutorado em Linguística) Universidade Estadual de Campinas, Campinas, 2011. Disponível em: http:// www.bibliotecadigital.unicamp.br/document/? code=000841960. Acesso em: 26 mar. 2016.

RUPELA, V.; VELLEMAN, S.L. ANDRIANOPOULOS, M.V. Motor speech skills in children with Down syndrome: A descriptive study. International Journal of Speech-Language Pathology, v. 18, 2016. Disponível em: http://www.tandfonline.com/doi/abs/

10.3109/17549507.2015.1112836? src=recsys\&journalCode=ias120. Acesso em: 10 ago. 2017.

SAUSSURE, F. Curso de Linguística Geral. 9ª Edição. São Paulo: Editora Cultrix, 1970.

SILVA, A.F. Estudo das características acústicas das fricativas do português do Brasil. Dissertação (Mestrado em Linguística e Língua Portuguesa) - Uni- 
versidade Estadual Paulista. 2012. Disponível em: http://repositorio.unesp.br/ handle/11449/92217. Acesso em: 10 jul. 16.

SOUZA, T.N.U.; PAYÃO, L.M.C. Apraxia da fala adquirida e desenvolvimental: semelhanças e diferenças. Revista Sociedade Brasileira de Fonoaudiologia, v. 13, n. 2, 2008. Disponível em: http://www.scielo.br/ scielo.php?pid=S1516-80342008000200015\&script $=$ sci_abstract\&tlng $=$ pt Acesso em: 10 ago. 2017.

TRUBETZKOY, N. A fonologia atual. In: DASCAL, M. (Org.) Concepções gerais da teoria Linguística. Campinas: Instituto de Estudos da Linguagem, 1981.

\section{BIBLIOGRAFIA CONSULTADA}

BARATA, L.F.; BRANCO, A. Os distúrbios fonoarticulatórios na Síndrome de Down e a intervenção precoce. Revista CEFAC. São Paulo, v. 12, n. 1,jan./ fev. 2010. Disponível em: http://www.scielo.br/pdf/rcefac/v12n1/a18v12n1. pdf. Acesso em: 12 mar. 2016.

BUNTON, K.; LEDDY, M.; MILLER, J. Phonetic Inteligibility Testing in Adults with Down Syndrome. Down Syndrome Research and Practice. Tucson, v.12, n. 1, jul. 2007. Disponível em: https://www.ncbi.nlm.nih.gov/pmc/ articles/PMC2805101/ Acesso em: 10 ago. 2017.

FERREIRA-SILVA, A.; PACHECO, V.; CAGLIARI, L.C. Descritores estatísticos na caracterização das fricativas do Português Brasileiro : Características espectrais das fricativas. In: Acta Scientiarum. Language and Culture. Maringá, v. 37, n.4, out-dez. 2015. Disponível em: http://periodicos.uem.br/ ojs/index.php/ActaSciLangCult/ article/view/25149 Acesso em: 16 jul. 2016.

JESUS, L. M. T.; SHADLE, C. A parametric study of the spectral characteristics of 
European Portuguese fricatives. Journal of Phonetics. Highfield, v. 30, jan. 2002. Disponível em: https://pdfs.semanticscholar.org/9e0c/ab3d2846638d4320097 a3bfb4c72eb10065d.pdf Acesso em: 12 nov.2016.

MARCHESAN, I.Q. Atuação Fonoaudiológica nas Funções Orofaciais: Desenvolvimento, Avaliação e Tratamento. In: ANDRADE, C.R.F. de; MARCONDES, E. Fonoaudiologia em pediatria. São Paulo: Sarvier, 2003. p. 3-22.

MARCHESAN, I.Q. Avaliando e tratando o sistema estomatognático. In: CAMPIOTTO, A.R. et al. Tratado de fonoaudiologia. São Paulo: Roca; 1997.p. 763-80.

OLIVEIRA, M.; PACHECO, V.; PEREIRA-SOUZA, L.P. Processos Fonológicos na fala de sujeitos com síndrome de Down: Uma interpretação via Geometria de Traços e Teoria Métrica da Sílaba. Caderno de Estudos Linguísticos, v. 59, n. 2, 2017. Disponível em: https://periodicos.sbu.unicamp.br/ ojs/index.php/cel/article/view/8649883/16622 


\section{AENTOAÇÃO NO COMPONENTE FONOLÓGICO DAGRA- MÁTICA: HALLIDAY (1970) E PIERREHUMBERT (1980)}

Luiz Carlos Cagliari

\section{Introdução}

A entoação é uma das partes da fonética descritiva que aparece tardiamente. Os estudos anteriores estiveram voltados para os sistemas de escrita das letras, com poucas referências à prosódia. Podemos dizer que essa preocupação com a entoação apareceu somente depois que vieram as notações musicais. O trabalho de Joshua Steele (1779) vem dessa abordagem musical na tradição britânica e americana. Desde então, desenhar a curva melódica é um fato comum a todos que estudam a entoação e chega até Pike (1945), Bolinguer (1958), Cristal (1969) e outros (Cagliari, 2007). Recentemente, a prosódia passou a ter um destaque nos estudos fonéticos (Hardcastle; Laver; Gibbon, 2013) e fonológicos (Goldsmith, 1995). Os modelos métricos trouxeram uma grande contribuição para os estudos da prosódia da fala (Nespor; Vogel, 1986; Hayes, 1995). O ritmo da fala e a entoação também tiveram destaque nos trabalhos mais recentes de fonética acústica (Cagliari et alii, 2012; Barbosa; Madureira, 2015). É impossível estudar a entoação sem estudar o ritmo.

Esse quadro geral mostra como os estudos prosódicos foram se diversificando e tornando-se muito abrangentes. Dentre todos os trabalhos que trazem um compromisso explícito de tratamento da prosódica dentro de modelos linguísticos estabelecidos, há um destaque para os trabalhos de Halliday e de Pierrehumbert. Halliday vem da tradição britânica de estudos ligada aos trabalhos de Daniel Jones (1909) e Firth (1957), seguindo um modelo basicamente estruturalista. Pierrehumbert vem da tradição americana de estudos da gramática gerativa (Chomsky, 1968) com foco na prosódia (Liberman, 1975; Goldsmith, 1995; Hayes, 1995). Pierrehumbert levou os estudos para a fonética acústica, ao passo que Halliday ficou com o uso auditivo da linguagem comum 
falada. Duas abordagens aparentemente incompatíveis entre si, mas que, dentro da preocupação fonológica de ambos, apresentam pontes de interpretação e até de notações.

Enquanto a teoria de Halliday se manteve com poucas alterações, porém, em poucos trabalhos (Cruttenden, 1986; Cagliari, 2007; Halliday; Greaves; 2008), a teoria de Pierrehumbert tem sido muito difundida e usada (Ladd, 1996; t’Hart, J.; Collier, R.; Cohen, 1990).

Este trabalho deixa de lado os trabalhos de entoação em geral e se concentra numa análise e comparação entre os modelos de Halliday (1973) e de Pierrehumbert (1980).

\section{O modelo de Halliday (1970)}

Ler o texto de Halliday (1963 / 1973) requer um conhecimento específico da teoria gramatical do autor e do modelo chamado de prosodic analysis, aplicado aos estudos fonológicos, seguindo uma tradição que vem de Firth (1957). Termos como grau de delicadeza, expoente fonológico, niveis gramaticais, aspecto formal etc. têm significados particulares na teoria que ele usa. Halliday estudou um córpus com mais de 2.000 tones, de onde tirou sua interpretação dos padrões entoacionais do inglês britânico. Serviu-se também de análises acústicas feitas por Katherine Patch (Halliday, 1973, p. 107) para caracterizar as variações de ritmo dos pés, dependendo do número de sílabas, numa proporção de 5:6:7 para pés rítmicos com uma, duas e três sílabas. Com esses dados, ele mostrou um sistema prosódico que descreve a tonicidade (ocorrências de silabas tônicas), os pés (sequências de sílabas tônicas e átonas), a tonalidade (ocorrências de grupos tonais definidos por tons fonológicos) e os tons (em número de cinco primários simples, dois compostos, mais suas variantes ou tons secundários).

Natural conversation in British Standard English may be represented as involving continuous selection from a set of five tones. These five tones constitute a phonological system, at a primary degree of delicacy, that is both chain-exhausting and choice-exhausting. That is to say, connected speech can, it is suggested here, be analyzed into an unbroken succession 
of tone groups each of which selects one or other of the five tones. For purposes of analysis, the selection can be regarded as discrete on both axes, both syntagmatically and paradigmatically: we can make a good description, that is, if we postulate that each tone group begins where the previous one ends, with no overlap and no hiatus, and that each tone group can be unambiguously assigned to one tone, this assignment thereby excluding all the other tones (1973, p. 103).

A escolha do corpus com elementos de conversas representa o contexto mais difícil para se estudar a entoação. Os estudos de logatomas ou de enunciados constituídos de expressões menores do que uma frase ou apenas de uma frase, embora possam ser melhor investigados, nem sempre revelam o que, de fato, acontece quando as pessoas falam. Na citação acima, Halliday menciona sequências contínuas de tons, porque as pausas são incorporadas na descrição do ritmo, ocupando lugares silábicos nos pés ou mesmo ocupando a duração de pés inteiros. Portanto, não destroem os grupos tonais, nem oferecem problemas descritos, como acontece com outras abordagens da entoação. A referência ao eixo paradigmático significa que o componente fonológico conta com apenas cinco padrões entoacionais, os quais serão selecionados devidamente para compor a descrição fonológica entoacional no eixo sintagmático. $\mathrm{O}$ fato de eles serem exclusivos e opositivos mostra a abordagem estruturalista funcional do autor. Halliday e Pierrehumbert não apresentam regras de juntura de tons. Os cinco tons são níveis de altura melódica distintivos e opositivos no sistema fonológico da língua. Como qualquer fenômeno linguístico, são suscetíveis de variações.

Each of the tones of course exhibits subdivision, to be regarded when the analysis is carried beyond the primary degree of delicacy. Delicacy is a variable to which no theoretical limit can be set; nor is there any valid and objective means of measuring it. But in a phonological statement it is possible to be guided, in the choice of an appropriate degree of delicacy, by certain formal considerations. In describing English intonation, we let the grammar decide how delicate we should be. This is made possible by the relation between phonology and linguistic form. (Halliday, 1973, p.103-104). 
A questão de grau de delicadeza é mais evidente na teoria funcionalista do que na teoria gerativa. A gramática gerativa parte de formas muito abstratas e aceitas inicialmente como um postulado. Na gramática funcional, a fala é investigada diretamente e, por essa razão, é preciso definir o grau de delicadeza. Se alguém grava conversas aleatórias e faz uma análise fonética detalhada pode encontrar ocorrências de regras contraditórias fonologicamente. Como o sistema não pode suportar contradições, deve-se organizar os dados em sistemas, ou seja, em graus de delicadeza. Essa é uma das razões pelas quais Chomsky optou por uma teoria top-down e não bottom-up, dedutiva e não indutiva. Halliday faz uma longa discussão sobre o assunto para esclarecer aquilo que Chomsky chama de intuição do falante, ou seja, há um grau de delicadeza que define algumas estruturas aceitas pelo falante como "normais" e outras como "não pertencentes à sua língua" ou a algum outro grau de delicadeza definido sociolinguisticamente. Pierrehumbert refere-se a esse aspecto como considerações de ordem pragmática. Continuando a citação acima, Halliday esclarece:

The reason for recognizing phonology as an independent level in descriptive linguistics is that this is the only way in which it can provide a bridge between form and substance. In phonology we make a separate abstraction from phonic substance, and represent this in statements which show how the given language organizes its phonic resources in such a way to carry (or expound) its grammatical and lexical patterns. If we tie phonology directly to form, the result is likely to be either excessive complication or distortion (Halliday, 1973, p.103-104).

Uma preocupação de Halliday é mostrar que, em inglês, o contraste de variação melódica não tem significado lexical, como em tailandês (língua tonal). Para ele, os dois tipos de línguas: entoacionais e tonais podem ser descritos pelo mesmo modelo. Pierrehumbert tem essa mesma visão teórica. Assim como ela, Halliday relaciona a entoação com o resto da gramática, como pontes e não como causas. A entoação funciona como qualquer outro contraste gramatical (tempo, modo etc.). Por outro lado, o sistema entoacional pode ser polysystemic, ou seja, pode haver mais de um sistema entoacional para uma 
língua, dependendo de quão comprehensive é o nível de delicadeza com que se define a gramática. Em outras palavras, dialetos diferentes podem ter sistemas entoacionais diferentes. Essa visão é compartilhada por Pierrehumbert. Por isso, ambos começam definindo o dialeto que aparece no corpus usado. Diferentemente de Pierrehumber, Halliday acha que não se pode descrever a entoação a partir da fonética, assim como não se pode associar os padrões dos tons a categorias gramaticais específicas. São descrições independentes. Ocasionalmente, há uma relação entre categorias gramaticais de outro nível com o sistema entoacional, mas não há nenhuma categoria que exija um padrão entoacional único e exclusivo ou vice-versa. Esse caráter abstrato e geral dos padrões entoacionais é também admitido por Pierrehumbert.

A partir de considerações teóricas preliminares como as apresentadas acima, Halliday passa a apresentar o seu modelo descritivo da entoação do inglês (britânico standard). Como acontece com Pierrehumbert, o nível de delicadeza da descrição dos padrões melódicos começa com a atribuição de valores aos pés rítmicos. Para ele, a teoria rítmica de Pike (1945) se aplica adequadamente ao inglês como língua de ritmo acentual. Pierrehumbert usa a teoria prosódica de Selkirk (1980) e a teoria métrica de Liberman e Prince (1977), descrevendo os pés rítmicos, aos quais serão atribuídos valores entoacionais do sistema de tons. Para Halliday, os pés rítmicos são organizados sintaticamente em enunciados de dois componentes, com objetivos informativos diferentes: dado / novo; tema /rema, os quais têm características entoacionais fonológicas próprias. A separação entre um e outro é feita pela sílaba tônica que define o foco do enunciado. O mesmo acontece com o modelo de Pierrehumbert, que considera um componente nuclear e um pré-nuclear.

No modelo de Halliday (também no de Pierrehumbert com a grade métrica), a descrição começa necessariamente com a atribuição de tonicidade às sílabas, que podem ser tônicas ou átonas. Para ambos, o que caracteriza uma sílaba tônica (em inglês) são sílabas whose exponents are market by contrast not only (if indeed at all) in intensity but also in pitch and duration (HALLIDAY, 1973, p. 108). A referência à intensidade vem do modo antigo de classificar os acentos como sendo primariamente de intensidade. Para Halliday, o valor de duração é 
mais importante do que o de altura melódica. Para Pierrehumbert, depende da elaboração da grade métrica, que é feita através das "possibilidades de atribuição de acento aos enunciados". Assim, para Halliday, uma palavra como Araraquara, teria apenas uma sílaba tônica (dois pés, um sincopado e outro com -quara). Para Pierrehumbert, a mesma palavra teria uma grade métrica com os valores: w s w s $\mathrm{w}$ ( $\mathrm{w}=$ weak, átono; $\mathrm{s}=$ strong, tônico). Para ela, somente no nível da palavra fonológica $(\omega)$, a situação se iguala à análise de Halliday. Acertados os pés rítmicos (Halliday) e métrico (Pierrehumbert), no caso do modelo de Halliday, o passo seguinte é fazer uma avaliação auditiva (em geral) ou acústica para definir o contorno do tom no componente pretônico e no componente tônico. A marca mais saliente ocorre na silaba tônica frasal, onde se encontra o foco do enunciado e uma mudança mais significativa da curva melódica. $\mathrm{O}$ mesmo ocorre no modelo de Pierrehumbert. No caso dela, a presença de uma sílaba tônica ao nível do pé métrico é assinalada com um asterisco (starred tone: $\mathrm{H}^{*}, \mathrm{~L}^{*}$ ), exceto no caso do phrase accent, que nunca é marcado com um asterisco. Para ambos, o que vem no componente pretônico (Halliday) ou prenuclear (Pierrehumbert) é secundário fonologicamente num primeiro grau de delicadeza. Somente secundariamente, o que ocorre nesse contexto passa a ser relevante, definindo atitudes do falante, padrões sintáticos (enumerações...), semânticos (atitudes do falante...) ou pragmáticos (atos de fala...). O sentido gramatical do padrão entoacional é dado pela curva melódica do componente tônico ou do que acontece entre o pitch accent e o boundary tone. Somando os tons de cada pé, tem-se um padrão entoacional ou tom entoacional no modelo de Halliday. Para ele, há apenas cinco desses padrões, numerados de 1 a 5 , no primeiro grau de delicadeza, ou seja, no sistema mais abstrato da fonologia da língua. Para Pierrehumbert, há apenas dois: $\mathrm{H}$ (high) e L (low). Para Halliday, há dois tons compostos (13 e 53), porque no enunciado, gramaticalmente estabelecido, há duas sílabas tônicas salientes, que são as que determinam a marcação do tipo de tom que ocorre. Esses tons são chamados de primários. Variações deles são chamadas de tons secundários. Todos os tons primários apresentam variantes quer no componente pretônico, quer no componente tônico. Para Pierrehumbert, a sequência de $\mathrm{H}$ e L atribuída aos pés no contexto prenuclear e ao pitch accent, ao phrase accent e ao boundary tone 
constitui a estrutura entoacional do enunciado, ou seja, os padrões entoacionais mais gerais que podem ser atribuídos pela gramática às ocorrências fonéticas da fala dos enunciados. Pierrehumbert considera também a presença de bitones, ou seja, ocorrência de variação de $\mathrm{H}$ e L em sílabas acentuadas dos pés que recebem um tom. Halliday dispensa a análise acústica, mas não a invalida. Pierrehumbert atribui os padrões aos enunciados (texts) através de regras de mapeamento, segundo um modelo de uso típico da gramática gerativa. Neste caso, deve haver uma "concordância" entre o padrão fonológico e a realidade fonética, expressa pela variação da frequência fundamental (F0). Essas regras de mapeamento só fazem sentido através de uma análise auditiva do enunciado, não sendo uma regra de aplicação automática. Essa passagem da estrutura profunda fonológica para a estrutura de superfície é devidamente estabelecida na gramática gerativa, não apenas para o componente fonológico, mas para os demais.

Para Halliday, os tags (vocativos...) são interpretados como pertencendo a um tom anterior, ou constituindo um tom próprio por si. Para Pierrehumber, os tags se apresentam como um problema sério para o modelo. Para resolver, ela criou um phrase accent composto: um atribuído normalmente, e outro atribuído ao tag.

Halliday apresenta um inventário de tons, com suas definições fonéticas e fonológicas. E faz uma apresentação geral do sistema:

It can be seen, therefore, that in any utterance in English three distinct meaningful choices, or sets of choices, are made which can be, and usually are, subsumed under the single heading o "intonation". These are: first, the distribution into tone groups - the number and location of the tone group boundaries; second, the placing of the tonic syllable (in double tonic tone groups, the two tonic syllables) - the location, in each tone group, of the pretonic and tonic sections; third, the choice of primary and secondary tone. I propose to call these three systems tonality, tonicity and tone. The three selections are independent of one another. They are not of course independent of the system of rhythm, the distribution of the utterance into feet; as long as the rhythm is kept constant, the number of possible choices in the second system, that of tonicity, is equal to the number of strong syllables - that is, the number of complete feet as defined above (Halliday, 1973, p. 112). 
Os enunciados com padrão sintático afirmativo são os mais neutros e representam o primeiro grau de delicadeza, assim como alguns outros, por exemplo, com padrão interrogativo. Estes, num outro grau de delicadeza, distinguem um sistema secundário para interrogativas polares ( $\operatorname{sim} /$ não), confirmativa não polar, wh- (com palavra interrogativa) ou interrogativas informativas. Pierrehumbert não lida diretamente com esses fatos gramaticais como a interrogação, tipo de frase sintática, porque estão fora do componente fonológico. Em inglês, as interrogativas têm padrões sintáticos bem definidos, razão pela qual podem variar a melodia, não precisando necessariamente de um contorno ascendente. Por outro lado, um contorno ascendente, em inglês, pode não estar associado a algum tipo de pergunta.

Finalmente, para a descrição da gramática funcional de Halliday, a interpretação semântica dos padrões entoacionais é uma consequência natural e não pode ser deixada para o componente semântico, como faz a gramática gerativa. Portanto, todos os tons primários vêm descritos com seus padrões fonológicos que identificam o movimento da curva melódica (falling, rising, fallin-rising, (rising-)-falling-rising... Os tons secundários têm, além da descrição primária, uma associação a um significado ou a um conjunto de significados gramaticais sintáticos, semânticos e pragmáticos: enunciado afirmativo neutro; de listagem, enfático, irônico, irritação, ato de fala etc.

Pierrehumber desenvolve uma longa discussão sobre o fato de a entoação ficar mais bem descrita em termos de níveis ou de tons fonéticos ( $\mathrm{H} \mathrm{e} \mathrm{L),} \mathrm{obtidos}$ através da análise do F0. Ela refuta o uso de níveis, adota os valores de F0. Além disso, acha que as línguas tonais africanas podem ser descritas do mesmo modo, apenas com H e L. Acontece que as línguas africanas têm, caracteristicamente, na sua atualidade, tons de níveis e não tons de contorno. Porém, uma língua como o chinês e algumas línguas indígenas (PIKE, 1945, 1947) necessitam de outros níveis, além de alto e baixo (o médio sendo sub-especificado ou, às vezes, flutuante). Como Halliday descreveu o sistema de tons do chinês, língua que ele conhece muito bem, o modelo descritivo dos tons de contorno só podia ser definido em termos de cinco níveis, como, por exemplo, um contraste entre um tom alto-baixo, meio-alto/meio-baixo (Pierrehumbert diria que se trata de uma 
diferença de spreading). Na verdade, teoricamente, os dois modelos não são contraditórios, mas têm graus diferentes de sutileza descritiva. $\mathrm{O}$ modelo de Halliday é mais evidente e claro, à primeira vista. $\mathrm{O}$ modelo de Pierrehumbert exige um conjunto de regras para definir exatamente o que significam as indicações fonológicas $\mathrm{H}$ e $\mathrm{L}$ dos tons nas intonational phrases.

Halliday menciona o efeito da tessitura que iguala, no sistema, realizações fonéticas diferentes, mas que apresentam um contraste estabelecido como sendo o mesmo no componente fonológico. Assim, uma sílaba pode ter uma altura melódica variável de acordo com o valor da F0, mas continuar, por exemplo, sendo um tom alto (ou de outra altura), apesar da variação acústica, porque o que define um tom é o sistema fonológico e não a realização fonética de um dado enunciado. Pierrehumbert faz uma longa discussão sobre o efeito downstep na entoação, que tem a ver com o efeito da tessitura e de outros fatores físicos da fala. Pierrehumbert discute detalhadamente o efeito downstep a ponto de estabelecer baseline units com fórmulas específicas de cálculo. Na verdade, o modelo conseguiria estabelecer o intonational mapping sem tais informações. Elas servem apenas para justificar certas interpretações que têm a ver com a variação de tessitura. Variação do valor de $\mathrm{H}$ e L é um fato fonético e não fonológico. A tessitura é um fato fonético e fonológico, mas sua função não é re-ordenar os valores da F0, mas indicar marcas discursivas, como enunciados parentéticos ou enfatizados (por exemplo, em altura melódica de falseto).

Como Halliday apresenta somente uma análise auditiva da entoação em seu modelo, ele pode trabalhar diretamente com a ortografia, acrescentando alguns devices gráficos. Assim, as fronteiras dos tons são marcadas com barras duplas inclinadas //. Os tons são indicados no início de cada enunciado, com o respectivo número acrescido ou não do diacrítico que define os tons secundários. Os pés rítmicos são separados por barras inclinadas, a partir do início da sílaba tônica. A sílaba tônica saliente, que marca o foco e que separa o enunciado em componente pretônico e tônico, vem indicada de modo sublinhado. As marcas de separação entre o componente pretônico e tônico são barras duplas verticais ||. A síncope e as pausas são marcadas com o caret tipográfico (marca de inserção em texto, um v de cabeça para baixo - neste trabalho 
é usado >). Halliday apresenta também visual symbols, marcando, através de linhas horizontais o movimento da altura melódica para cada pé, com especial referência à terminal tendency, uma espécie de preocupação de como acaba a entoação no fim do enunciado. Pierrehumbert também considera esse contexto de importância fundamental e atribuiu a ele o boundary tone. Halliday trabalha com cinco níveis de altura melódica: alto, meio-alto, médio, meio-baixo, baixo. A transcrição simbólica pictográfica costuma aparecer sobre uma pauta musical (eu uso uma pauta de três linhas).

A transcrição dos tons no modelo de Halliday exige um treinamento fonético auditivo específico, semelhante ao que se faz para a transcrição das qualidades vocálicas, seguindo o método das vogais cardeais (Abercrombie, 1967), ou semelhante ao treinamento para a transcrição de tons de línguas tonais. Esse treinamento acostuma o ouvido com as variações de altura melódica, à moda das notas musicais, o que permite ao linguista transcrever os tons entoacionais com uma simples análise auditiva. Sem isto, obviamente, como acontece com as notas musicais, a pessoa se sentirá confusa e pode achar que tal empreitada é impossível, dada à variação que ouve. Alguns exemplos de análise apresentados por Halliday são dados a seguir, juntamente com algumas informações gerais sobre seu sistema.

Figura 1 - Exemplos de análise entoacional do modelo de Halliday com representação dos tons primários simples, dos pés e com representação pictográfica da variação melódica

\begin{tabular}{|l|}
\hline Tom 1 primário simples: \\
\hline Basic form: \\
\hline Example: \\
Easic form: \\
Example: \\
$\quad / 2$ do they / take the / car when they / go a / broad $/ /$
\end{tabular}




\begin{tabular}{l} 
Tom 3 primário simples: \\
\hline Basic form: : \\
\hline Example: \\
\hline Example: 4 primário simples: \\
\hline Tom 5 primário simples: \\
\hline Basic form: - Example:
\end{tabular}

Fonte: Halliday (1970, p. 10-11).

Figura 2 - Exemplos de análise entoacional do modelo de Halliday com representação dos tons primários compostos, dos pés e com representação pictográfica da variação melódica

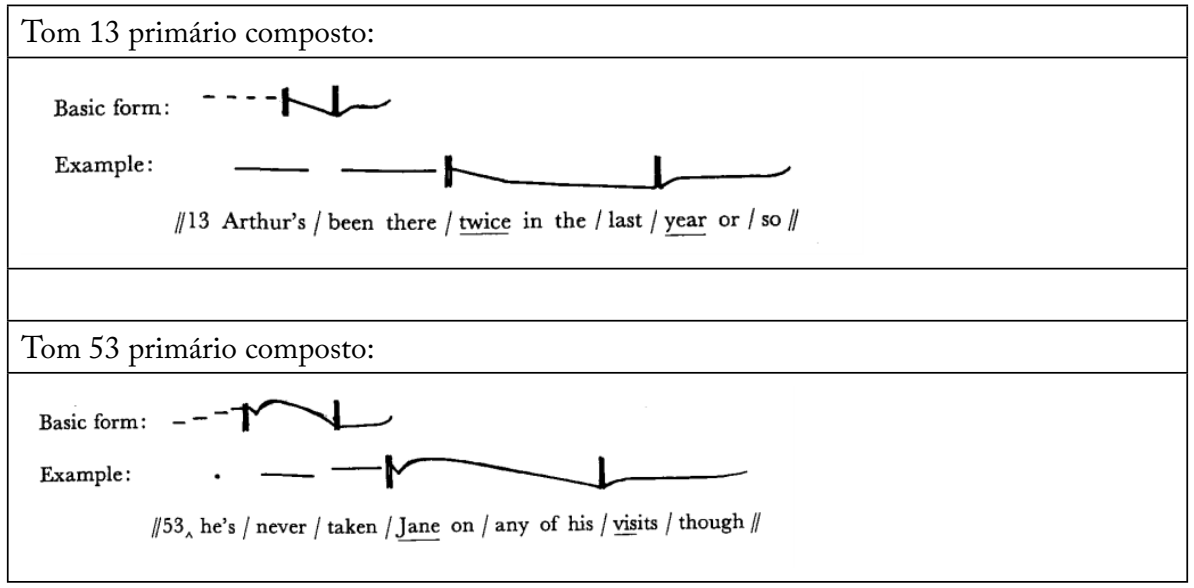

Fonte: Halliday (1970, p. 10-12). 
Figura 3 - Exemplos de análise entoacional do modelo de Halliday, mostrando sequência de tons. O segundo exemplo mostra um enunciado com tag. A variação melódica é representada pictograficamente

\section{Sequência de tom 4 \& 1 :}

4 \& 1 (dependent clause followed by its main clause)

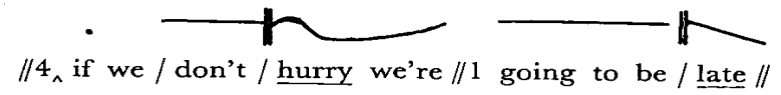

A tag cannot have a pretonic:

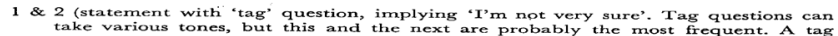

cannot have a pretonic)

//1, they / live in / Bcckenham// 2 don't they /

1 \& 1 (statement with 'tag' question, implying ' $I$ 'm fairly sure they do')

//1, I

// 1, they / live in / Beckenham // don't they /

Fonte: Halliday (1970, p. 13).

Figura 4 - Exemplos de análise entoacional do modelo de Halliday, mostrando pictograficamente a variação melódica no componente pretônico

Tom $\underline{5}$ secundário com variação no componente pretônico baixo/alto/baixo e com o componente tônico com nível meio-baixo/médio/baixo:

Example:

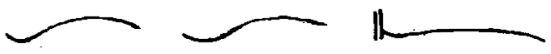

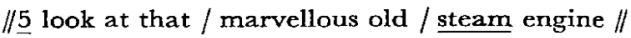

Tom 4 secundário com variação no componente meio-alto/médio alternados e com o componente tônico com nível meio-alto/médio/meio-alto:

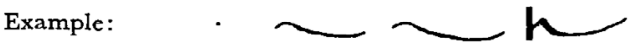

\|4 $4_{\wedge}$ but it / certainly / couldn't be / animal //

Fonte: Halliday (1970, p. 18-19). 
Figura 5 - Exemplos de análise entoacional do modelo de Halliday, mostrando pictograficamente a variação melódica no componente pretônico para um enunciado com valor melódico não nivelado (uneven) e para um enunciado com variação melódica de uma sequência de itens (listing)

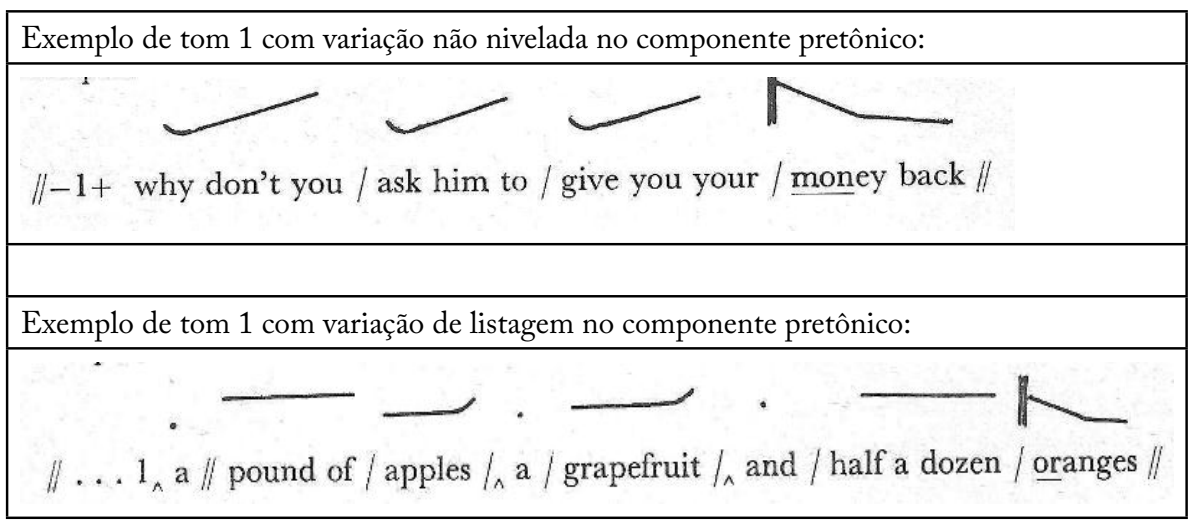

Fonte: Halliday (1970, p. 16).

Figura 6 - Esquema do modelo teórico de Halliday para os tons primários simples e compostos (Halliday, 1973, p. 110)

The primary tone system is as follows:

\begin{tabular}{|c|c|c|c|}
\hline $\begin{array}{l}\text { term in } \\
\text { system: }\end{array}$ & $\begin{array}{l}\text { visual } \\
\text { symbol: }\end{array}$ & $\begin{array}{l}\text { tonic } \\
\text { movement: }\end{array}$ & $\begin{array}{l}\text { terminal } \\
\text { tendency: }\end{array}$ \\
\hline 1 & $\backslash$ & falling & low \\
\hline \multirow{2}{*}{2} & / & rising & high \\
\hline & & falling-rising & high \\
\hline 3 & $\longrightarrow$ & rising & mid \\
\hline 4 & & (rising-)falling-rising ${ }^{(12)}$ & mid \\
\hline 5 & & (falling-)rising-falling ${ }^{(12)}$ & low \\
\hline
\end{tabular}

Double tonics:

$\begin{array}{llll}\begin{array}{l}\text { term in } \\ \text { system: }\end{array} & \text { visual } & \text { tonic } & \text { terminal } \\ \text { symbol: } & \text { movement: } & \text { tendency: } \\ 13^{(13)} & \text { (as tone 1 plus tone 3) } & \text { mid } \\ 53^{(13)} & \text { (as tone 5 plus tone 3) } & \text { mid }\end{array}$

Fonte: Halliday (1973, p. 110). 
Figura 7 - Exemplos de tons secundários com va riação no componente tônico, segundo o modelo de Halliday (1973, p. 110)

\section{A: Secondary systems at tonic}

\begin{tabular}{|c|c|c|c|c|}
\hline $\begin{array}{l}\text { term in } \\
\text { primary } \\
\text { system: }\end{array}$ & $\begin{array}{l}\text { term in } \\
\text { secondary } \\
\text { system: }\end{array}$ & $\begin{array}{l}\text { transcription } \\
\text { symbol: }\end{array}$ & $\begin{array}{l}\text { visual } \\
\text { symbol: }\end{array}$ & $\begin{array}{l}\text { tonic } \\
\text { movement: }\end{array}$ \\
\hline \multirow{3}{*}{1} & (1 wide & $1+$ & 1 & high to low \\
\hline & 1 (neutral) & 1 & & mid to low \\
\hline & 1 narrow & $1-$ & 一 & mid-low to low $\mathrm{w}^{(14)}$ \\
\hline & (2 (neutral) & 2 & I & rising to high \\
\hline 2 & 2 broken & $\underline{2}$ & V & $\begin{array}{l}\text { high falling-rising to } \\
\text { high }\end{array}$ \\
\hline \multirow[t]{2}{*}{4} & $\int 4$ (neutral) & 4 & & falling to mid, rising \\
\hline & 4 low & $\underline{4}$ & & falling to low, rising \\
\hline
\end{tabular}

Fonte: Halliday (1973, p. 110).

Figura 8 - Exemplos de tons secundários com variação no componente pretônico, segundo o modelo de Halliday (1973, p. 111)

B: Secondary systems at pretonic

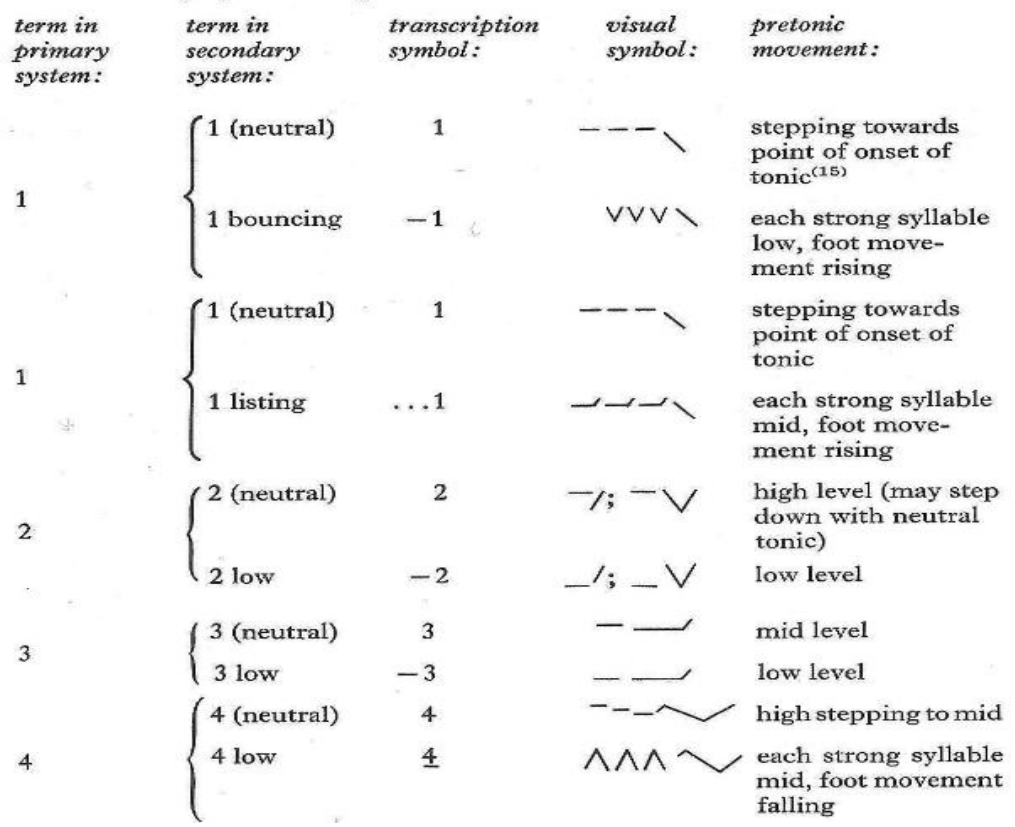

Fonte: Halliday (1973, p. 111). 


\section{Modelo descritivo de Pierrehumbert (1980)}

O modelo teórico de Pierrehumbert aparece de modo completo em sua tese de doutorado (1980). Posteriormente, houve algumas pequenas modificações ou sugestões feitas por ela e por outros pesquisadores (LADD, 1996; GUSSENHOVEN, 2002). A modificação mais significativa veio com uma descrição da entoação do japonês, que é uma língua de ritmo silábico, interpretada como língua de ritmo "moraico" (Beckman; Pierrehumbert, 1986). A interpretação do japonês como língua moraica é muito problemática e baseada em uma teoria do ritmo que não se aplica à tradicional divisão entre língua de ritmo acentual e língua de ritmo silábico (Cagliari, 2007, p. 27 nota 20). As moras do japonês têm a ver mais com a escrita literária do que com a fonética. A abordagem do japonês não será objeto de estudo neste trabalho, apenas a versão original que deu origem à teoria, que passou a ser chamada de teoria métrica autossegmental (AM) da entoação. Essa abordagem tem a ver com a teoria métrica (Liberman; Prince, 1977) e com a teoria autossegmental de Goldsmith (1980). Para levar adiante sua teoria, ela precisou incorporar a representação da tonicidade através da grade métrica da fonologia prosódica e, eventualmente, fazer referência à sintaxe, à semântica e à pragmática, como elementos esclarecedores e não incorporados ao sistema fonológico adotado. Como o modelo foi criado dentro da gramática gerativa (versão padrão: Chomsky, 1965), é fundamental que se leve em conta sempre esse fato. É ela que explica muitas das decisões que o modelo adota.

A análise entoacional de qualquer enunciado exige uma análise da grade métrica, porque é através dela que ficam definidas as sílabas tônicas e, num nível superior, os pés métricos.

The starred / unstarred relation in pitch accents may be compared to the stressed / unstressed relationship within the metrical foot, an entity which will also play a role in our discussion of text / tune association (Pierrehumbert, 1980, p. 23). 
É sobre os pés métricos que se aplicam os tons fonológicos, cuja sequência compõe os padrões fonológicos distintivos da língua. Nesse sentido, o trabalho de Pierrehumbert segue o mesmo esquema de Halliday. Para Pierrehumbert, a unidade básica fonológica se caracteriza por ter um tom alto $(\mathrm{H})$ ou baixo (L), sem outras possibilidades. Como a curva melódica da fala segue oscilações de alto e baixo, a descrição pode ser feita em função das variações do F0. Diante de um enunciado, Pierrehumbert atribui uma sequência de tons $\mathrm{H}$ e L somente às sílabas tônicas dos pés e a sequência define os padrões entoacionais fonológicos da língua. Logo no Abstract, a autora diz:

This thesis develops a system of underlying representation for English intonation. It gives an account of what different tunes are possible and how they are aligned with different texts. It characterizes the rules which map the underlying representations into phonetic realizations. The different tunes are described as structured strings of $\mathrm{L}$ and $\mathrm{H}$ tones generates by a finite-state grammar (Pierrehumbert, 1980, p. 2).

Diante do mesmo enunciado, Halliday anota as variações de altura melódica de todas as sílabas e a forma do contorno define os padrões entoacionais em termos de unidades fonológicas básicas ( 5 tons simples e 2 compostos primários). Os dois autores dividem o enunciado com a localização da sílaba tônica frasal, isto é, onde se localiza o foco semântico do enunciado. Halliday chama essa sílaba de sílaba tônica saliente e Pierrehumbert a chama de nuclear pitch accent. Para ela, as sílabas dos pés que precedem o foco são chamadas de prenuclear pitch accents. Para Halliday, o que vem antes é o componente pretônico e o que vem a partir do foco é o componente tônico. Para Pierrehumbert, o que ocorre antes é o componente prenuclear e o que ocorre a partir do foco é o componente nuclear. Para ambos, o que ocorre antes do foco é secundário, caracterizando apenas secundariamente o padrão entoacional fonológico, sendo, no mais das vezes, variantes ligadas às atitudes do falante. A definição dos cinco tons distintivos do sistema fonológico entoacional de Halliday é feita pela configuração do contorno melódico do componente tônico. Para Pierrehumber, a questão é mais complicada. Ela anota a sílaba tônica frasal (foco 
ou núcleo) e o final do enunciado entoacional: o final boundary stress. O fim é anotado com $\mathrm{H}$, se houver uma subida da curva melódica. Nos demais casos, será atribuído o valor L, mesmo que não haja queda da curva melódica, mas apenas um valor nivelado, vindo de antes. A razão disto é uma restrição do modelo que trabalha somente com dois valores H e L. O final do enunciado é sempre muito importante para a definição da entoação. Pode acontecer de o foco ser também a última sílaba. Mesmo nesses casos, o modelo exige a marca de fim (boundary tone). Entre a sílaba do foco e o fim do enunciado, sempre deverá ser marcado um tom $\mathrm{H}$ ou L, chamado de phrase accent. Ele é atribuído à variação mais notável do F0 que ocorre entre o nuclear pitch accent e o boundary tone, independentemente de cair ou não em uma sílaba tônica de um pé métrico, embora esse seja o contexto mais indicado, se houver.

A teoria de Pierrehumbert considera que toda sílaba tônica dos pés métricos deva ter uma saliência fonética representada pela frequência fundamental (com a ajuda da duração). Halliday também tem essa expectativa. De fato, esse é um fato fonético notável. A questão da percepção ou do reconhecimento dessa saliência fonética não é tão simples, fato destacado pelos dois teóricos. Halliday conta sempre com uma mudança notável na curva melódica ou com uma sequência de altura nivelada. Pierrehumbert trabalhou mais com enunciados que apresentaram grandes variações no F0. As ocorrências de tons nivelados é um problema para ela, resolvido com a noção de plateau. A implementação dos tons entre as tônicas justifica essa análise. As variações melódicas mais longas, porque as sílabas tônicas costumam ser mais longas, são analisadas com uma regra de spreading. Na maioria dos casos, esse spreading acaba formando o que ela chama de bitones, ou seja, sequências de $\mathrm{H}+\mathrm{L}$ ou de $\mathrm{L}+\mathrm{H}$, conforme o caso. As sílabas tônicas nucleares e prenucleares são marcadas com um asterisco. As sílabas do phrase accent nunca é marcada com asterisco, mas podem ser também um bitone. Essa abordagem, como outros aspectos teóricos, segue Goldsmith (1976). A autora acrescenta uma marca especial, em alguns casos que, segundo minha interpretação, indica tons de contorno tradicionalmente usados na fonética de línguas tonais. Ela diz: 
The tone which leads or trails the starred tone will be marked with a raised hyphen... This contrasts $\left(\mathrm{H}^{*}+\mathrm{H}^{-}\right)$with a plain $\mathrm{H}^{*}$ accent because the $\mathrm{H}^{-}$is subject to tone spreading and generates F0 plateaus which would not arise from $\mathrm{H}^{*}$ (Pierrehumbert, 1980, p. 23).

Pierrehumbert fez um levantamento exaustivo (mas não completo) dos padrões fonológicos entoacionais do inglês americano e chegou ao seguinte esquema:

Figura 9 - Esquema do modelo teórico de análise da entoação de Pierrehumbert (1980,p. 29)

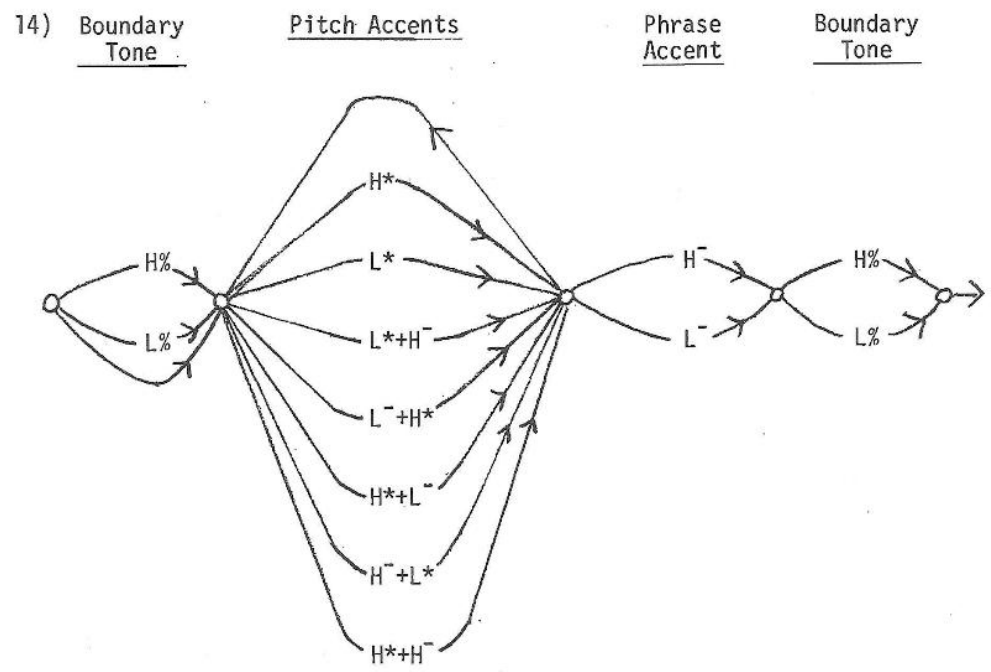

Fonte: Pierrehumbert (1980, p. 29).

No esquema acima, aparecem marcados os boundary tones inicial e final. Os pitch accents são os que ocorrem na sílaba do núcleo ou sílaba onde se localiza o foco. O termo boundary stress define o final acústico (F0) de um enunciado, e o termo boundary tone refere-se ao valor fonológico do tom. No esquema, falta o phrase accent extra que ocorre no caso das tags. Uma tag pode vir separada por um boundary tone. O símbolo \% é usado para separar as intonational phrases e é a marca típica da pausa também.

O modelo teórico de Pierrehumbert é gerativo, mas não usa regras de derivação. Em vez disso, usa um sistema representacional de mapping, ou seja, 
um padrão fonológico entoacional é atribuído a um enunciado (text) através de uma representação (mapping) que configura o enunciado entoacionalmente. Um mapping precisa atribuir uma unidade do esquema acima, mais um número não definido e não necessário de pitch accents no componente prenuclear. $\mathrm{O}$ boundary tone inicial não precisa ser atribuído, a não ser que tenha um valor (F0) alto: comece com $\mathrm{H}$ e tenha contorno descendente.

Pierrehumbert apresenta uma série de regras de mapping, de alignment, de spreading, de formação de plateau, de implementação de baseline units e, principalmente, de downstep e de upstep. As duas últimas têm a ver com a variação de tessitura, embora a regra de upstep esteja ligada ao final do enunciado e não ao que vem antes. Pierrehumbert discute como seu modelo pode também descrever as línguas tonais, com algumas diferenças. Goldsmith (1980) já tinha mostrado que o modelo autossegmental podia ser usado também para descrever a entoação do inglês. A discussão sobre a declination do F0 leva a autora a uma longa análise do que chama baseline e baseline units. Essa preocupação é decorrente do fato de Pierrehumbert se apoiar nos valores da F0 e não na percepção da variação melódica da fala. Tal problema não se coloca para Halliday. Mesmo para Pierrehumbert, é um problema menor para a definição fonológica dos padrões entoacionais a serem atribuídos aos enunciados. Ela define a baseline a partir do menor valor de F0 do falante, o qual deve ocorrer no fim de uma frase entoacional: o L mais L. A partir daí, calcula-se um ângulo com regras da direita para a esquerda que implementam baseline units até o início do enunciado numa linha crescente. Desse modo, segundo ela, todos os valores de F0, do início ao fim da frase entoacional, têm uma proporção de altura melódica compensada pelo efeito da tessitura. Se houver mais frases entoacionais em sequência, o valor da baseline é calculado para todas as frases entoacionais, a partir da F0 mais baixa, o que costuma acontecer numa frase entoacional situada mais à direita. Uma pausa pode reestruturar o sistema criando uma nova baseline. Em geral, um falante tem uma baseline característica que lhe é própria.

Por ser uma tese de doutorado, Pierrehumbert pode desenvolver seu modelo teórico com detalhes e de modo abrangente. Embora traga muitos dados analisados, a maioria representa enunciados isolados, não mostrando 
sequências de frases entoacionais, como faz Halliday (1970). No final, ela faz um resumo de sua discussão, apresentando o modelo claramente. No apêndice às figuras, Pierrehumbert conclui:

All possible combinations of nuclear pitch accent, phrase accent, and boundary tone, and how they are realized by our rules for implementing tones... There are 22 different patterns. 6 of the logically possible 28 patterns are omitted because the implementation rules neutralize them with other forms. These are $\mathrm{H}^{*}+\mathrm{L}^{-} \mathrm{L}^{-} \mathrm{L} \%$ and $\mathrm{H}^{*}+\mathrm{L}^{-} \mathrm{L}^{-} \mathrm{H} \%$, which are neutralized with $\mathrm{H}^{*} \mathrm{~L}^{-} \mathrm{H} \%$, respectively, and all four cases of $\mathrm{H}^{*}+\mathrm{H}^{-}$, which is neutralized with $\mathrm{H}^{*}$ for either phrase accent (Pierrehumbert, 1980, p. 390).

Os schematized patterns do apêndice da tese são representações do tipo apresentado por Halliday, valendo como padrões fonológicos entoacionais. Nesse sentido, o modelo de Halliday acaba sendo mais simples do que o de Pierrehumbert. A seguir, apresentam-se alguns exemplos de análises tirados da tese da autora (PIERREHUMBERT, 1980). Os exemplos foram escolhidos para apresentar alguns casos particulares da análise e interpretação de Pierrehumbert. Os exemplos seguem as numerações da tese e me referirei a eles nos comentários. O objetivo não é discutir os exemplos, mas simplesmente apresentá-los com comentários gerais. 
Figura 10 - Exemplos tirados da tese de doutorado de Pierrehumbert (1980) para mostrar como a autora interpretou alguns tipos de enunciados

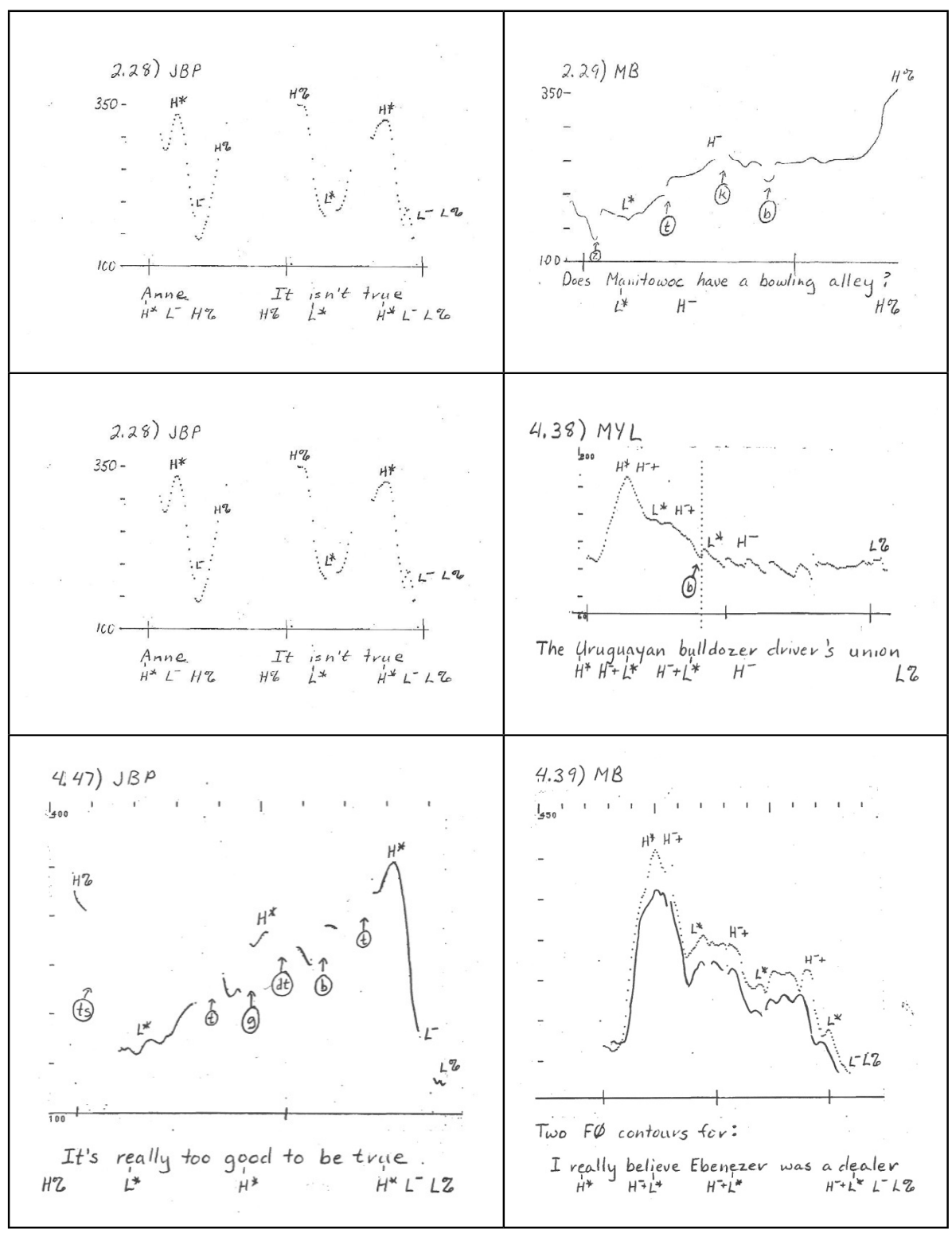

Fonte: Pierrehumbert (1980).

O exemplo 2.28 mostra dois tunes ou intonational phrases, separados por $\mathrm{H} \%$. A variação da altura melódica é muito grande, indo de aproximada- 
mente 100 cps a 350 cps, o que dá duas oitavas musicais. Os tons com hífen sobrescrito mostram tons de contorno. O exemplo 2.29 mostra uma frase interrogativa com o foco na primeira sílaba da palavra Manitowoc e com uma curva melódica ascendente. O exemplo 2.38A mostra duas intonational phrases, separadas por L\%. Na segunda, o foco está na palavra $d r y$, que apresenta um tom de contorno $\mathrm{H}^{*} \mathrm{~L}^{-}$. O enunciado foi pronunciado com um tom "médio", terminando em um tom "baixo". Quando um enunciado começa com sílabas átonas, é comum que haja um movimento ascendente no início até atingir uma altura um pouco mais alta daquela que segue no enunciado, como no exemplo apresentado. No exemplo 4.38, o nuclear stress ou foco ocorre na sílaba bullda palavra bulldozer. $\mathrm{O}$ componente prenuclear apresenta várias sílabas com pitch accents: $\mathrm{H}^{*} \mathrm{H}^{*}+\mathrm{L}^{*}$. $\mathrm{Na}$ sílaba nuclear, ocorre um contorno melódico $\mathrm{H}^{-}+$ L* (um bitone). A marca final L\% é atribuída porque a curva melódica não é ascendente. A variação do F0 vai de aproximadamente 100cps a 200cps. Esse tipo de enunciado tem um tom alto no começo e, no final, um plateau em nível médio (cerca de 100cps), representando uma frase que indica uma afirmação incompleta. $\mathrm{O}$ exemplo 4.47 mostra um contorno melódico ascendente (upstep). Como a sílaba nuclear (foco) localiza-se na última sílaba do enunciado, aparece marcado com um (bitone), ou seja, um tom de contorno (spreading). $\mathrm{O}$ início é marcado com $\mathrm{H} \%$ porque a curva melódica começa em uma altura alta, marcada entoacionalmente. $\mathrm{O}$ exemplo 4.39 mostra duas realizações variantes, com características marcantes de downstep. Em pronúncias desse tipo, a ocorrência de bitones é inevitável. O valor descendente da curva melódica, reforçada nas sílabas tônicas dos pés métricos, produz o efeito auditivo de "terraços" ou “andares" que descem. No exemplo 4.44, ocorre um tag (vocativo) sem que haja uma quebra do intonational phrase com pausa. Para dar conta desse tipo de enunciado, Pierrehumbert acrescenta mais um phrase accent, daí o padrão $L^{*}$ $\mathrm{H}^{-} \mathrm{H}^{-} \mathrm{H} \%$. Os dois phrase accents vêm marcados com o hifen por causa do upstep, e não por formar bitones, que são marcados com o sinal +. A marca de hifen sobreposto é assim atribuída porque o tom ocorre em sílabas diferentes (não bitone). O exemplo 4.12 mostra o efeito da baseline e como calcular graficamente as baselines units. $\mathrm{Na}$ pronúncia de JBP, a baseline varia pouco menos de 50 cps no enunciado. $\mathrm{O}$ exemplo mostra um valor bem alto do F0 ( $\mathrm{L}$ por volta de 275 cps e $\mathrm{H}$ por volta de 370 cps). É um típico chamado. 
Figura 11 - Esquema do contorno tônico apresentado por Pierrehumbert (1980, p. 397)

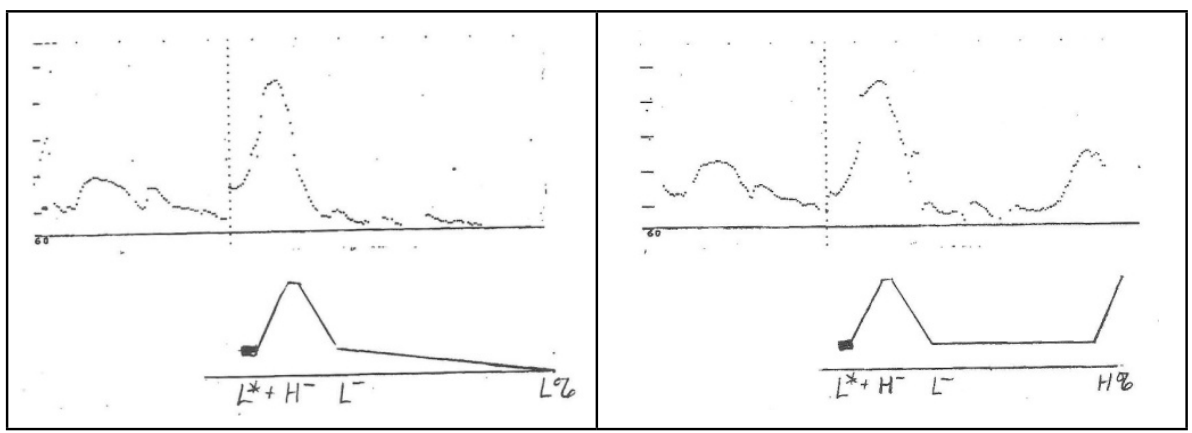

Fonte: Pierrehumbert (1980, p. 397)

Na Figura 11, Pierrehumbert (1980, p. 397) apresenta dois dos 22 exemplos de variação do foco (nuclear pitch accents), do final da intonational phrase (boundary tone) e da forma do contorno tônico de modo esquemático. Esses esquemas representam padrões auditivos e se relacionam com os valores acústicos do F0. Eles correspondem aos esquemas pictográficos de Halliday para o componente tônico, porque esse contexto é o que estabelece os contrastes fonológicos entoacionais. $\mathrm{Na}$ representação acústica, a linha vertical mostra o início da sílaba onde cai o foco, ou seja, na sílaba bull- da palavra bulldozer. Todos os exemplos do apêndice são variantes do enunciado The Uruguayan bulldozer drivers' union.

\section{Análise dos exemplos de Pierrehumbert no modelo teórico de Halliday (1970) e dos exemplos de Halliday no modelo teórico de Pierrehumbert (1980)}

Ladd (1996) apresenta e discute exaustivamente o modelo de Pierrehumbert. Entre outros comentários, diz o seguinte:

Despite appearances, there is much in the basic Pierrehumbert taxonomy of English intonation that is comparable with earlier analyses, in particular those of the British tradition. While denying any theoretical status to the notion of nuclear accents, Pierrehumbert (1980, in the Appendix to the Figures) illustrates the realization of the twenty-two occurring combinations of pitch accent, phrase tone, and boundary tone in a way that invites comparison to traditional British nuclear tones (Ladd, 1996, p.81-82). 
Ladd (1996, p. 81-82) faz vários comentários, lembrando que o modelo gerou 28 tons possíveis, mas que, por razão de neutralizações, o inventario ficou com apenas 22. Ele apresentou uma lista dos 22 tons de Pierrehumbert e acrescentou os tons do inglês britânico, como costumam aparecer definidos na literatura. Minha interpretação não coincide exatamente com todas as interpretações de Ladd. A seguir, apresento os exemplos de Pierrehumbert analisados de acordo com o modelo de Halliday.

Figura 12 - Exemplos de Pierrehumbert analisados no modelo de Halliday
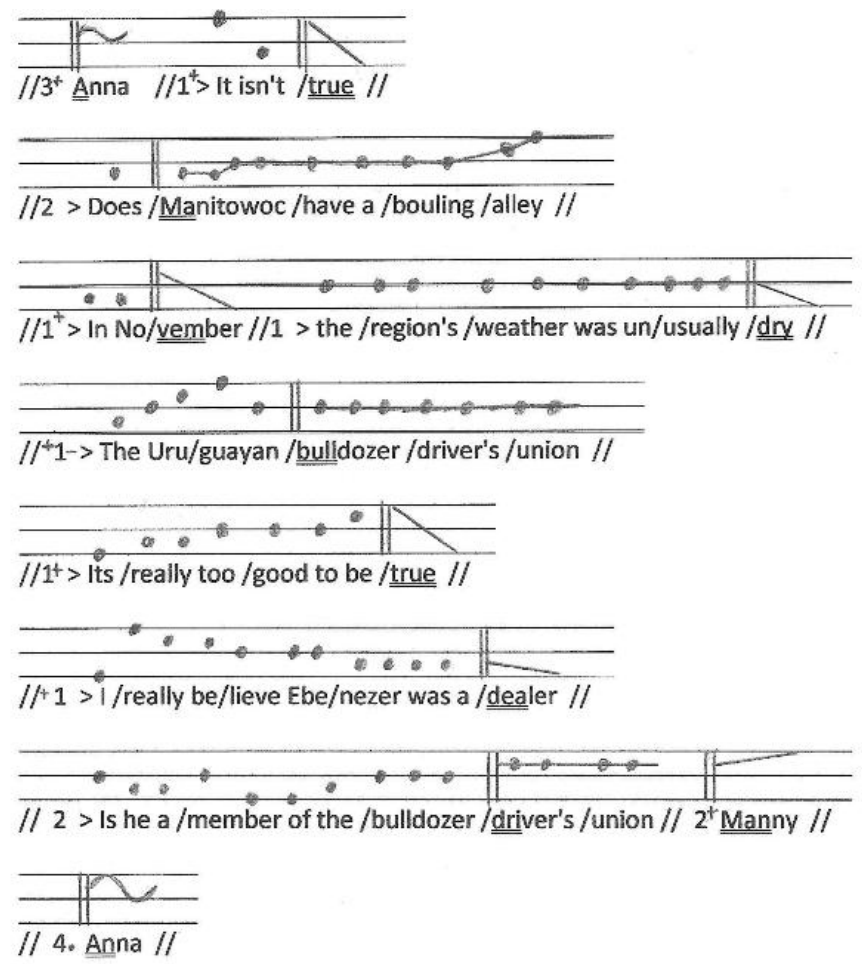

Fonte: Pierrehumbert (1980)

$\mathrm{Na}$ Figura 12, em vez da pauta de 5 linhas, foi usada uma pauta de 3 linhas. Halliday marca os tons secundários com diacríticos. Assim, T+ significa um tom com altura melódica mais alta do que no tom normal; $\mathrm{T}$ - significa um tom com altura melódica mais baixa do que no tom normal; T. significa uma variação melódica "estreita", ou seja, com pouca variação; ...T significa uma 
pretônica de listagem. Esses diacríticos servem tanto para definir o padrão do componente tônico, como do componente pretônico. $\mathrm{O}$ vocativo, Manny aparece em um grupo tonal separado. $\mathrm{Na}$ análise de Pierrehumbert fica incorporado à intonation phrase que o precede. A diferença entre o tom 3 e o tom 4 (para Anna) representa um tom suspensivo para 3 e um chamado para 4. Como não ocorre uma pretônica, a simples realização da tônica mostra uma curva melódica semelhante para os dois tons.

Abaixo, são apresentados os exemplos de Halliday neste trabalho, analisados no modelo de Pierrehumbert.

Quadro 1 - Representação da entoação através do modelo de Pierrehumbert

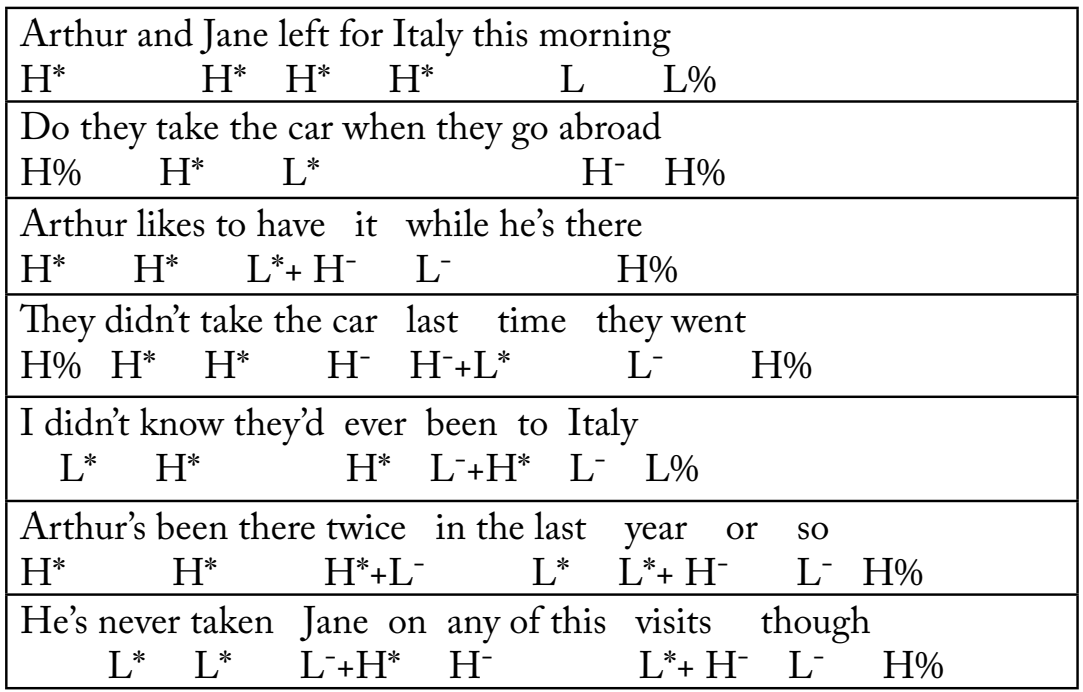

Fonte: elaboração própria.

Os exemplos acima correspondem aos tons primários simples e compostos. Convertendo sua forma fonológica para a de Pierrehumbert, temos o seguinte:
Tom 1:
$\mathrm{H}^{*} \mathrm{~L} \quad \mathrm{~L} \%$
Tom 2:
$\mathrm{L}^{*} \mathrm{H}^{-} \mathrm{H} \%$
Tom 3:

$$
\mathrm{L}^{*}+\mathrm{H}^{-} \mathrm{L}^{-} \mathrm{H} \%
$$
Tom 4:
$\mathrm{H}^{-}+\mathrm{L}^{*} \quad \mathrm{~L}^{-} \mathrm{H} \%$
Tom 5:
$\mathrm{L}^{-}+\mathrm{H}^{*} \quad \mathrm{H}^{-} \mathrm{H} \%$
Tom 13:
$\left(\mathrm{H}^{*}+\mathrm{L}^{-}\right)$prenuclear
$\left(\mathrm{L}^{*}+\mathrm{H}^{-} \mathrm{L}^{-} \mathrm{H} \%\right)$ nuclear accent
Tom 53:
$\left(\mathrm{L}^{-}+\mathrm{H}^{*}\right)$ prenuclear
$\left.\mathrm{L}^{*}+\mathrm{H}^{-} \mathrm{L}^{-} \mathrm{H} \%\right)$ nuclear accent 
Sem os valores do F0, é mais difícil localizar bitones. No esquema pictórico de Halliday, eles são neutralizados, exceto nas tônicas dos tons $3,4 \mathrm{e}$ 5. Os tons compostos precisam de uma definição específica no componente prenuclear no modelo de Pierrehumbert. Nesse modelo, as pretônicas são neutralizadas pelos padrões das tônicas, isto é, são previsíveis, portanto, esses prenuclear accents não precisam ser representados, exceto se começarem por $\mathrm{H} \%$. Comparando os esquemas teóricos (modelos fonológicos) de Pierrehumbert e de Halliday, as análises aqui apresentadas mostram que há uma correspondência muito exata entre uma abordagem e outra. Do esquema das tônicas de Pierrehumber, apenas os padrões $\mathrm{H}^{*}+\mathrm{L}^{-}$e o padrão $\mathrm{H}^{*}+\mathrm{H}^{*}$ não apareceram no esquema de Halliday. $\mathrm{O}$ primeiro padrão, no entanto, caracteriza o prenuclear accent dos tons compostos de Halliday. Quanto ao padrão $\mathrm{H}^{*}+\mathrm{H}^{-}$, Pierrehumbert faz longa discussão para verificar se ele existe ou não (Pierrehumbert, 1980, p. 226-230).

\section{Conclusão}

O presente trabalho apresentou a teoria fonológica funcional da entoação de Halliday (1970) e a teoria fonológica gerativa da entoação de Pierrehumbert (1980). Embora os modelos sejam diferentes formalmente, quando comparados, eles são surpreendentemente semelhantes ou, pelo menos, apresentam uma ponte que permite passar uma análise realizada em um modelo para uma análise no outro modelo. Por ser de base auditiva, o modelo de Halliday apresenta uma simplificação na transcrição, fruto de abstrações e generalizações feitas através dos contrastes fonológicos da entoação, captados auditivamente. Por outro lado, por apoiar-se nos valores da frequência fundamenta (F0), o modelo de Pierrehumbert precisou estabelecer regras de mapeamento, para alinhar os fenômenos fonéticos acústicos com as interpretações fonológicas subjacentes da entoação. O fato de ela optar por apenas dois tons $\mathrm{H}$ e L, a obrigou a estabelecer regras como downstep e upstep, e outras, para justificar as variações nos valores acústicos (F0) e as interpretações do sistema entoacional. Para Halliday, a tessitura está fora do sistema entoacional porque é compensa- 
da pelo ouvido. Sua análise é independente da entoação. Para Pierrehumbert, a saída foi estabelecer uma baseline e regras de atribuição de baseline units. As duas teorias privilegiam as sílabas tônicas e, de modo especial, a sílaba tônica que indica o foco semântico. As sílabas tônicas são interpretadas no nível dos pés (métricos / rítmicos), com uma grade métrica para Pierrehumbert e com uma marcação do ritmo, no caso de Halliday. As duas teorias se opõem a outros modelos, como o de Pike (1945), de Bolinger (1986) e de outros.

\section{Referências}

BECKMAN, M.E.; PIERREHUMBERT, J.B. Intonational structure in Japanese and English. In: Phonology Yearbook, 3. Great Britain. 1986, p. 255-309.

BECKMAN, M. E. and AYRES, G. M. ToBI annotation conventions. 1994. (http://ling.ohio-state.edu/tobi/ame_tobi/). Acesso em 30/11/2011.

BLOCH, B. and TRAGER, G. L. Outline of linguistic analysis. Baltimore: Special publication of the Linguistic Society of America. 1942.

BLOOMFIELD, L. Language. New York: Holt. 1933.

BOLINGER, D. A theory of pitch accent in English. In: Word.14,1958.p.109-149.

Around the edge of language: intonation. In: Harvard Educational Review 34. Cambridge. 1964. p. 282-296.

Intonation and its parts: the melody of language. Stanford: Stanford University Press. 1986.

CAGLIARI, L.C. Prosódia: ontem e hoje. In: Em torno da lingua (gem): questões $e$ análises. FONSECA-SILVA, M.C.; PACHECO, V. e LESSA-DE-OLIVEIRA, A.S.C. (org.). Vitória da Conquista: Edições UESB. 2007, p. 15-40.

CAGLIARI, Luiz Carlos. Elementos de Fonética do Português Brasileiro. São Paulo. Editora Paulistana. 2007 
CAGLIARI, Luiz Carlos; CARVALHO, Mariane; GEMENTI, Mariana Moretti. Revisiting the acoustic and auditory approach to speech analysis and corpora. In: Proceedings of the VIth GSCP International Conference: Speech and Corpora. Firenze: Firenze University Press. 2012, v. 1, p. 238-241.

CHOMSKY, N.; HALLE, M. The sound pattern of English. New York: Harper and Row. 1968.

COUPER-KUHLEN, E. An introduction to English prosody. London: E. Arnold, 1986.

CRYSTAL, D. Prosodic systems and intonation in English. Cambridge: Cambridge University Press. 1969.

CRYSTAL, D.; QUIRK, R. Systems of prosodic and paralinguistic features in English. The Hague: Mouton. 1964.

CRUTTENDEN, A. Intonation. Cambridge: Cambridge University Press. 1997.

CRYSTAL, David. Prosodic Systems and Intonation in English. Cambridge: Cambridge University Press. 1969.

CUTLER, A.; LADD, R. Prosody: models and measurements. Berlin: Springer. 1983.

FIRTH, J. R. Papers in linguistics: 1934-1951. London: Oxford University Press. 1957.

FUJISAKI, H. Characteristics of voice fundamental frequency in speech and singing. In: MacNEILAGE, P. (ed.) The production of speech. Berlin: Springer. 1983, p. 37-47.

GOLDSMITH,J. A. Autosegmental phonology. New York: Garland Press. 1979.

GOLDSMITH, J. A. English as a tone language. In: GOYVAERTS, D. (ed.) Phonology in the 80s. Gent. Story Scientia. 1980, p. 287-308. 
GRABE, E. Comparative intonational phonology: English and German. Ph.D. Dissertation. University of Nijmegen. 1998.

GRICE, M.; LADD, R.; ARVANITI, A. On the place of phrase accents in intonational phonology. In: Phonology, 17, 2000, p. 143-185.

GUSSENHOVEN, C. Intonation and interpretation: phonetics and phonology. In: BEL, B.; MARLIEN, I. Speech Prosody 2002 - An International Conference. Aix-en-Provence. Laboratoire Parole et Langage. CNRS and Univ.de Provence. 2002. p. 47-57.

Phonology of intonation. In: Glot Inter. Oxford: Blackwell. 2002, p. 271-284.

JONES, D. An outline of English phonetics. Cambridge: W. Heffer and Sons Ltd. 1918.

HALLIDAY, M.A.K. A course in spoken English: intonation. London: Oxford University Press. 1970

The Tones of English. In: Phonetics in Linguistics: a book of readings. JONES, W. E.; LAVER, J. (eds.). London: Longman, 1973, p. 103-126.

HALLIDAY, M.A.K.; GREAVES, William S. Intonation in the Grammar of English. London. Equinox Publishing Ltd. 2008.

HAYES, Bruce. Metrical Stress Theory: principles and case studies. Chicago: The University of Chicago Press. 1995.

HIRST, D.; DI CRISTO, A. Intonation system: survey of twenty languages. Cambridge: Cambridge University Press. 1998.

JUN, S.-A. (ed.) Prosodic typology and transcription: a unified approach. Oxford: Oxford University Press. 2003. 
KINGDON, R. Groundwork of English intonation. London: Longmans. 1958.

LADD, R. The structure of intonational meaning: evidence from English. Bloomington: Indiana University Press. 1980.

Intonational phonology. Cambridge: Cambridge University Press. 1996.

LIBERMAN, A. Mark. The intonational system of English. Cambridge: MIT. (Ph.D. Dissertation). 1975.

LIBERMAN, M.; PRINCE, A. On stress and linguistic rhythm. In: Linguistic Inquiry 8(2). 1977. p. 249-336.

NESPOR, M.; VOGEL, I. B. Prosodic Phonology. Dordrecht: Foris. 1986.

O'CONNOR J; ARNOLD G. Intonation of colloquial English. London: Longman. 1973

PALMER, H. English intonation, with systematic exercises. Cambridge: Heffer. 1922.

PIERREHUMBERT, J. B. Phonetics and phonology of English intonation. Ph.D. dissertation. MIT. 1980. (Published by Garland Press, New York, 1990).

PIKE, K. The intonation of American English. Ann Arbor: Un. Michigan Press. 1945.

SELKIRK, E. The role of prosodic categories in English word stress. In: Linguistic Inquiry, 11(3). 1980. p. 563-606.

STEELE, Joshua. Prosodia rationalis : or, An essay towards establishing the melody and measure of speech, to be expressed and perpetuated by peculiar symbols. Londres: J. Nichols, 1779 - ( $2^{\text {a }}$ ed. corrigida e aumentada disponível em https:// archive.org/details/prosodiarationa01steegoog ). 
't HART, J.; COLLIER, R.; COHEN, A. A perceptual study of intonation: an experimental phonetic approach to speech melody. Cambridge: Cambridge University Press. 1990.

TRAGER, G.; SMITH, H. An outline of English structure. Norman: Battenburg. 1951.

ULDALL, E. Attitudinal meanings conveyed by intonation. In: Language and Speech, 3. 1960. p. 223-234. 


\section{A PROSÓDIA MUSICAL COMO PISTA PARA O RITMO LINGUÍSTICO: ANÁLISE DE JINGLES DE PROPAGAN- DAS TELEVISIVAS}

Gladis Massini-Cagliari

\section{Introdução}

Estudos comparativos entre música e fala, apesar de não serem comuns, não são inéditos, talvez pelo fato de que estudiosos como Sloboda (2008), por exemplo, a partir de uma perspectiva da Psicologia Cognitiva, considerarem que o ser humano tem uma "mente musical", e que estudos de Fonologia, como o de Massini-Cagliari (2015), colocarem a prosódia como "a música da fala". Já Joaquim José Coelho de Carvalho, em 1910 (citado por Mateus, 2018, p. 306), no livro Prosódia e ortografia, afirmou que "falar é tocar um instrumento de música, o mais perfeito de quantos harmónios têm sido inventados”.

No contexto possível desta aproximação entre Música e Linguística, merecem destaque os estudos já clássicos de Jackendoff e Lerdahl (1980) e Lerdahl e Jackendoff (1983). Mais recentemente, podem ser citados os trabalhos de Curtis e Bharucha (2010) e Chobert e Besson (2013). No Brasil, é bastante conhecido e aclamado os livros de Tatit (2007) e Tatit e Lopes (2008). Especificamente sobre a pronúncia do português cantado, vejam-se os trabalhos reunidos em Pacheco (2009). Vale a pena citar, também, teses e dissertações sobre questões que aproximam as áreas de Música e Linguística, defendidas mais recentemente, no contexto de Programas de Pós-Graduação da área de Letras e Linguística, desse o pioneiro estudo de Medeiros (2002), até as dissertações e teses de Gelamo (2006), Lima (2007), Benfatti (2010), Souza (2014) e Machado (2017). Especificamente nas áreas de Fonética e Fonologia, alguns trabalhos têm sido desenvolvidos recentemente, desde Hayes e Kaun (1996) e, mais recentemente, Coutinho e Dibben (2013); no Brasil, vale 
a pena citar as contribuições de Carmo Jr. e Santos (2010), Carmo Jr. (2011, 2012), Lemos, Carmo Jr. e Shimoda (2018) e Ferreira Netto (2017).

O presente trabalho ${ }^{1}$, entretanto, no contexto de trabalhos de aproximação entre essas duas áreas, situa-se a partir de um posicionamento bastante específico: trata-se de um estudo na área de Fonologia, cujo objetivo é perscrutar as contribuições possíveis da observação da prosódia musical para a determinação da prosódia linguística de períodos específicos da língua. Trata-se da apresentação de parte dos resultados de uma pesquisa mais ampla, que congrega os esforços desta pesquisadora e de alguns de seus orientandos. O Projeto em cujo contexto se desenvolveu este estudo está integrado aos trabalhos do Grupo de Pesquisa "Fonologia do Português: Arcaico E̋ Brasileiro", registrado no Diretório dos Grupos de Pesquisa do CNPq, que tem como objetivo principal a descrição comparativa de aspectos fonológicos da Língua Portuguesa no seu período dito arcaico, em especial o trovadoresco (fins do século XII até meados do século XIV), e no seu período atual (no Brasil). Congrega um grupo de estudantes de Graduação e de Pós-Graduação da Faculdade de Ciências e Letras da Universidade Estadual Paulista (UNESP), Campus de Araraquara, coordenados por esta pesquisadora. Através da descrição de fenômenos segmentais e suprassegmentais do português medieval e do português atual, o grupo pretende, a longo prazo, chegar à descrição do componente fonológico da língua, naquela época, e a hipóteses de mudanças linguísticas ocorridas, desde as origens do português até os dias de hoje. A relevância das pesquisas reside, principalmente, na descrição, ao lado de fenômenos fonológicos segmentais, de fenômenos prosódicos (tais como acento, ritmo) e outros fenômenos que exigem um tratamento não linear (estruturação silábica e outros processos dela dependentes) de um período passado da língua.

Este trabalho, a exemplo das demais pesquisas incluídas no projeto, objetivou analisar as relações entre ritmo musical e ritmo linguístico (e, portanto, entre letra e música), focalizando as coincidências e não coincidências entre

1 Este estudo apresenta resultados parciais de pesquisa desenvolvida no contexto de um projeto de Produtividade em Pesquisa do CNPq (processos 303297/2013-1 e 302648/2019-4), e de um auxílio à pesquisa no âmbito do Edital 43/2013 - Ciências Humanas, Sociais e Sociais Aplicadas (processo 405562/2013-6, já finalizado). 
proeminências nos níveis musical e linguístico. A proposta das pesquisas do grupo se baseia principalmente na hipótese de que proeminências musicais combinam-se prioritariamente com proeminências linguísticas. No entanto, há a possibilidade de proeminências musicais serem ocupadas por sílabas que não correspondam a proeminências linguísticas (pelo menos, não proeminências principais). Apesar de haver a possibilidade de não coincidência entre as proeminências do texto e da música, isso não pode acontecer na maior parte dos casos, tendo que se restringir a um uso estilístico marginal, porque, do contrário, não haveria a possibilidade de produção e reconhecimento de um padrão rítmico, já que os padrões de ritmo poético e musical se baseiam na repetição de estruturas. Assim, ao testar essa hipótese, as pesquisas do projeto objetivam verificar as contribuições que a análise do ritmo musical pode trazer para a compreensão do ritmo linguístico - mediado, no caso de letras de música, pela dimensão poética. Por este motivo, a metodologia busca averiguar como se dá a relação entre proeminências nesses três níveis diversos, que se encontram quando do advento da música cantada: música, poesia e língua.

O projeto busca, também, observar a relação ente ritmo musical e linguístico em gêneros musicais diversos e de épocas diferentes. Caso essa relação se mostrar relevante com relação a canções de gêneros musicais atuais, aos quais é possível ter acesso a partir de diferentes fontes (performances, gravações, registros escritos de letra, partituras e/ou tablaturas etc.), será possível estender o raciocínio a períodos passados da língua, quando ainda não havia a possibilidade tecnológica de registros sonoros, mas dos quais sobreviveram registros escritos, inclusive partituras de músicas para serem cantadas. Portanto, por se tratar de um grupo de pesquisa voltado não apenas ao estudo da Fonologia do Português Brasileiro atual, mas também à Fonologia histórica do português, a pesquisa em cujo contexto se desenvolveu o presente estudo objetiva também mostrar que uma análise em paralelo do texto poético e da notação musical de cantigas medievais trovadorescas se constitui em um instrumento auxiliar importante para a análise linguística do acento e do ritmo de períodos passados da língua, dos quais não sobreviveram registros orais. 
Assim, a pesquisa tem por objetivo mais abrangente confirmar a possibilidade de uma conexão entre a música e a linguística no desenvolvimento de uma nova metodologia para o estudo da prosódia de línguas atuais ou de períodos anteriores de línguas vivas ou já mortas (tal como já fizeram Massini-Cagliari, 2008a,b, 2010a,b, 2011 e Costa, 2010, para o Português Arcaico, séculos XIII-XIV). Para atingir esta finalidade, a metodologia adotada baseia-se na observação das proeminências musicais de textos poéticos musicados, na observação das proeminências linguísticas do texto dos poemas, junto com a observação da estrutura métrica dos mesmos.

\section{Prosódia musical e prosódia linguística}

Por prosódia musical, entendemos a organização das proeminências musicais no tempo, em termos de ritmo, e, também, de melodia. Entretanto, mesmo entre músicos, muitas vezes o termo "prosódia musical” é já preliminarmente definido em termos da relação entre letra e música, focalizando a colocação do texto em frases musicais, considerando a acentuação das palavras e as proeminências musicais. Exemplificando, Baleiro, (2013, p. 1) define prosódia musical como a "relação entre a acentuação silábica das palavras e os acentos da estrutura musical”.

Do ponto de vista linguístico, Scarpa $(1999$, p. 7$)$ mostra que "o conjunto de fenômenos que se convenciona chamar de prosódia é tão antigo quanto extenso". Couper-Kuhlen (1986, p. 1) mostra que o termo prosódia, historicamente, remonta aos gregos, que o usavam para se referir aos traços da fala que não podiam ser indicados na ortografia, especificamente tom e acento melódico. Desta forma, desde os primórdios, o termo associou-se a traços melódicos da língua falada.

O fato de, como na Música, a fala apresentar melodia (entoação, tons) e harmonia (acento e ritmo) tem aproximado a definição linguística de prosódia de termos musicais. Assim, Trask (2004, p. 242) define prosódia, remetendo-se ao nível fonético, como "variações em altura, volume, ritmo e tempo (velocidade de emissão) durante a fala”. Por outro lado, Xavier e Mateus (1990, p. 300) 
restringem-se ao nível da ortoépia ${ }^{2}$, definindo o termo como "pronúncia regular das palavras no que respeita ao acento e à quantidade (ou duração), e que constitui a base da métrica”. Já Camara Jr. (1973, p. 322) alertava para o uso de prosódia como termo sinônimo de ortoépia, acepção que emprestam ao termo as linguistas portuguesas. Porém, e anteriormente a Trask, Camara Jr. (1973, p. 322) já trazia a definição de prosódia para os domínios da Fonologia, explicando-a como a "parte da fonologia referente aos caracteres da emissão vocal que se acrescentam à articulação propriamente dita dos sons da fala, como em português o acento e a entoação". É por este motivo que unidades maiores do que os segmentos, tais como a sílaba, as moras silábicas, o pé, o grupo tonal, os tons entoacionais, bem como fenômenos como a tessitura e o tempo, são chamados de "prosódicos" (Massini-Cagliari; Cagliari, 2001, p. 112).

\section{Análise de jingles de propagandas televisivas}

Por analisar as relações entre proeminências musicais e linguísticas na língua portuguesa cantada, este estudo focaliza a interface Música-Linguística, com o objetivo de investigar em que medida a análise da relação entre letra e música pode contribuir para a elucidação de questões relativas à prosódia linguística, a partir de uma concepção de prosódia musical como a de Baleiro (2013).

O objetivo é verificar se, apesar da sua discrepância na gênese, há ou não, subjazendo à concepção poético-musical dessas canções, um princípio de coincidência entre proeminências musicais e poéticas. Trata-se, aliás, de um princípio que sobrevive até os dias de hoje e que norteia a composição de músicas populares em diversos idiomas, incluindo o português do Brasil, na opinião de compositores e poetas. Esta é a opinião do próprio Zeca Baleiro (2013, p. 1) considera a aproximação da prosódia nos dois níveis, musical e linguístico, mas considera, também, a possibilidade de subversão artística dessa correlação.

2 "Parte da gramática normativa que, tendo em vista o uso culto, a pronúncia tradicional e os traços fonológicos relevantes, determina e prescreve no âmbito da fonologia de uma língua: 1) a escolha entre as variantes livres dos fonemas; 2) a nitidez de articulação dos grupos vocálicos e consonânticos; 3) os tipos de ligação que se devem fazer ou evitar; 4) as modalidades condenáveis de metaplasmo; 5) a sílaba que deve receber o acento nos vocábulos de acentuação duvidosa." (Camara Jr., 1973, p. 292) 
Conheço compositores, alguns dos quais amigos e/ou parceiros, que têm verdadeira obsessão com a "correção" da prosódia. Eu não. Me agrada a barafunda infinita das palavras de nosso idioma inesgotável e gosto de me perder em suas mil e uma possibilidades de entonação e divisão. Em meu favor, uso o argumento de que a prosódia da canção é próxima à da fala (semelhante, não igual), e assim como esta, é imperfeita, torta e sem regras muito claras. Portanto, não acho que se possa falar em "correção" quando o assunto é língua falada, e a canção é, grosso modo, uma extensão da coloquialidade da fala. Poderia mesmo dizer que um dos grandes baratos da canção é poder ouvir palavras às vezes ressignificadas pelo ritmo proposto pelo compositor.

Como já mostrei anteriormente em Massini-Cagliari (2009, p. 1684), Chico Buarque de Holanda também comenta sobre a maneira como age, com relação à combinação de acentos musicais e linguísticos, na Coleção de DVDs Chico: A série, no DVD1 (Meu caro amigo. RWR Comunicações Ltda, EMI Music Brasil Ltda, 2006):

A letra que você faz para a música, você tem que fazer para aquela música que já existe, que já tem uma forma fixa. Você não pode alterar nada. As pessoas falam isso, comparam muito com poesia; não tem nada a ver, é outra coisa. Mas é muito mais difícil, porque você tem que fazer aquela letra, respeitando cada nota, a métrica, que não é exatamente a mesma coisa que fazer uma fórmula fixa de um soneto, não, não é uma fórmula fixa. Cada frase é de um tamanho diferente. Você tem que respeitar a prosódia musical, ou seja, a letra, a tônica das palavras coincidir com a tônica da música. Ou desrespeitar a prosódia de propósito e tal; e tudo isso, e, no fim, e rimas, e rimas, e, no fim, ainda fazer algum sentido, de preferência, ficar uma coisa interessante ou bonita de se ouvir.

Com o objetivo de investigar como se comporta a organização das proeminências linguísticas e musicais em músicas populares de circulação atual no Brasil, no contexto das pesquisas desenvolvidas pelo Grupo de Pesquisa "Fonologia do Português: Arcaico Ė Brasileiro", optou-se por iniciar a investigação a partir de um gênero acessível a todos e de ampla circulação em diferentes mídias: os 
jingles de propaganda. Optou-se por iniciar a abordagem por este gênero também pela sua diminuta duração, em termos temporais, o que facilita a averiguação da viabilidade e da adequação da metodologia empregada. Além disso, como se trata de um gênero desenvolvido como forma de divulgação de um produto e de convencimento do consumidor para comprá-lo, parte-se do pressuposto de que tanto o texto quanto a música dessas pequenas canções têm que ser agradáveis aos ouvidos, sob pena de não atingirem seu objetivo prático de vender.

Do ponto de vista da análise das correlações entre texto e música, parte-se da ideia de que o tempo forte do compasso musical (o primeiro tempo) marca preferencialmente uma proeminência no nível linguístico, podendo servir de base para a localização das sílabas tônicas das palavras do texto.

Apresentaremos neste estudo, como exemplo do método de pesquisa empregado, a análise de três jingles: a propaganda identificada como Edifício Sky Futebol Comercial HDTV 22s (disponível em https://www.youtube. com/watch?v=JBXtR_HHRCI), o jingle Pão de açúcar O que faz você feliz comercial 1080i (HDTV) (disponível em https://www.youtube.com/watch?v=e8wFwOvttsg) e o jingle clássico Duchas Corona, de 1978 (disponível em; https://www.youtube.com/watch?v=LJjLWKuvaRk).

A Press Release da campanha da Sky, da qual faz parte o jingle Edifício Sky Futebol aqui considerado, traz a seguinte Ficha Técnica:

FICHA TÉCNICA Cliente: SKY

Título: Edifício SKY Produto: Aquisições

Agência: Giovanni+Draftfcb

Direção executiva de criação: Joanna Monteiro e Max Geraldo

Diretor de Arte: Enio Kawahara

Redator: Carlos Castelo

Mídia: Alexandre Ugadin, Tiago Santos, Vinicius Loschiavo, Camila Fiuza, Luca Lima, Caroline Rebelatto

Atendimento: Mauro Silveira, Marco Aymoré, Renata Velloso, Renata Batalha, Camila Rossignolo

Planejamento: Raphael Barreto, Luciana Mussato, César Fuster, Daniele Leão RTV: Vivi Guedes e Karina Bueno 
Produtora de imagem: Fulano Filmes

Direção: Mariana Youssef

Direção de fotografia: Adolpho Veloso

Atendimento: Karina Amabile

Produtor executivo: Krysse Mello

Coordenação de Finalização: Alexandre Cois/Sabrina Comar

Finalizador: Adriano Torres

Animação: Vinícius Kos

Ilustração: KAKO

Composição: Jorge Alaniz / Lauro Santhiago

Montagem: Umberto Martins

Finalização: Fulano Filmes

Produtora de áudio: Timbre

Produtores: Mairena, Lucas Lopes

Arranjo: Leandro Santos

Locutor: Edson Montenegro

Aprovação do cliente: Marcelo Miranda e João Paulo Marques

Em (2), apresenta-se a letra do jingle Edifício Sky Futebol Comercial HDTV, na versão de 22 segundos. Neste e nos próximos exemplos, foram marcadas todas as sílabas que coincidiam com proeminências musicais tônicas, seguindo o padrão em (1):

(1)

$$
\begin{aligned}
& \text { vermelho - tônicas } \\
& \text { roxo - monossílabos tônicos } \\
& \text { azul - pretônicas } \\
& \text { laranja - átona final } \\
& \text { rosa - monossílabo átono } \\
& \text { verde - pausa }
\end{aligned}
$$

Nesse edifício / todo mundo tem (i)Sky

Um contou pro outro, / ninguém ficou pra trás

Por paixão ao futebol, o Zé trocou sua tevê

Para ver todos os lances na Sky em agá dê 
Como se pode ver a partir da Tabela 1 , em $72.5 \%$ dos casos há coincidência na posição das proeminências musical e linguística $(51.7 \%$ com sílabas tônicas $+20.8 \%$ com monossílabos tônicos).

Tabela 1 - Pauta prosódica das sílabas em posição inicial do compasso musical: Edifício Sky

\begin{tabular}{lr}
\hline $\begin{array}{l}\text { Pauta prosódica da sílaba em posição inicial } \\
\text { do compasso musical }\end{array}$ & $\begin{array}{r}\text { quantidade de unidades de } \\
\text { tempo (compassos) }\end{array}$ \\
\hline tônica & $15(51.7 \%)$ \\
\hline monossílabo tônico & $6(20.8 \%)$ \\
\hline monossílabo átono (clítico) & $1(3.4 \%)$ \\
\hline pretônica & $3(10.3 \%)$ \\
\hline átona final & $2(6.9 \%)$ \\
\hline nenhuma sílaba & $2(6.9 \%)$ \\
\hline TOTAL & $29(100 \%)$ \\
\hline
\end{tabular}

Fonte: Elaboração própria.

Desconsiderando-se os momentos em que a proeminência musical não coincide com material linguístico, como foi feito na Tabela 2, a coincidência na posição das proeminências musical e linguística sobe para $77.8 \%(55.6 \%$ com sílabas tônicas $+22.2 \%$ com monossílabos tônicos). Em 3 casos (11.1\%), a tônica musical coincide com uma pretônica linguística. Em apenas $11.1 \%$ dos casos o tempo forte do compasso recai sobre uma sílaba átona, do ponto de vista linguístico: 1 monossílabo átono (3.7\%) e duas sílabas átonas finais (7.4\%).

Tabela 2 - Pauta prosódica das sílabas em posição inicial do compasso musical: Edifício Sky (desconsiderando a ausência de material linguístico em posição de proeminência musical)

\begin{tabular}{lr}
\hline $\begin{array}{l}\text { Pauta prosódica da sílaba em posição inicial } \\
\text { do compasso musical }\end{array}$ & $\begin{array}{r}\text { quantidade de unidades de } \\
\text { tempo (compassos) }\end{array}$ \\
\hline tônica & $15(55.6 \%)$ \\
\hline monossílabo tônico & $6(22.2 \%)$ \\
\hline monossílabo átono (clítico) & $1(3.7 \%)$ \\
\hline pretônica & $3(11.1 \%)$ \\
\hline átona final & $2(7.4 \%)$ \\
\hline TOTAL & $27(100 \%)$ \\
\hline
\end{tabular}

Fonte: Elaboração própria. 
Desde Camara Jr. (1985[1970], p. 63), considera-se, para o Português Brasileiro (PB) que as sílabas pretônicas não são "débeis", ou seja, desprovidas de proeminência, mas carregam uma proeminência intermediária.

No registro formal da pronúncia padrão do português do Brasil há a rigor uma pauta acentual para cada vocábulo. As sílabas pretônicas, antes do acento, são menos débeis que as postônicas, depois do acento. Se designarmos o acento, ou tonicidade, por 3 , em cada vocábulo, temos o seguinte esquema:

$$
\ldots(1)+3+(0)+(0)+(0)
$$

indicando os parênteses a possibilidade de ausência de sílaba átona (nos monossilabos tônicos) e as reticências um número indefinido de sílabas pretônicas.

Desta maneira, se considerarmos as sílabas pretônicas como portadoras de uma proeminência intermediária, não tão forte quanto a proeminência primária, da sílaba tônica lexical da palavra, mas secundária, o percentual de coincidência entre proeminências musicais e linguísticas, no jingle considerado, sobre para $88.9 \%$, um percentual muito próximo dos $90 \%$. Este resultado aponta para uma forte tendência em fazer coincidir as proeminências rítmicas nos dois níveis, musical e linguístico, na confecção de jingles televisivos.

Em contrapartida, resta um percentual de $11.1 \%$ de casos em que não há coincidência entre as proeminências musicais e linguísticas. Estes devem ser os casos focalizados nos próximos períodos desta pesquisa, porque podem trazer pistas de fenômenos rítmicos importantes da língua, para além de possibilidades de usos estilísticos desviantes (que, por serem desviantes, não podem ser percentualmente dominantes, obviamente).

Baleiro (2013, p. 3) mostra que pode haver duas interpretações para esses casos desviantes: resultado de um ato artístico voluntário, caso em que deve ser buscada a razão do uso desviantes, ou simplesmente falta de habilidade do poeta/músico:

Considero este recurso (trapacear nas acentuações silábicas em prol do ritmo ou simplesmente da mágica de inventar um novo som) algo bem inteligente, embora vez ou outra possa ser só fruto de desatenção ou mesmo falta de engenho. 
No jingle considerado, o posicionamento de proeminências musicais sobre sílabas átonas finais de palavra parece indicar a tentativa de manutenção de um rítmico trocaico (alternante de forte/fraco) - em laranja, em (3). O mesmo objetivo parece suprir o posicionamento da proeminência musical sobre o clítico um, marcado em roxo em (3). Reforça este fato a retração acentual ocorrida na palavra agá, marcada em amarelo, que parece servir ao mesmo propósito. Caso aceitemos esta interpretação, trata-se de uma escolha voluntária do compositor/poeta.

\section{Um contou pro outro, / ninguém ficou pra trás \\ Por paixão ao futebol, o Zé trocou sua tevê \\ Para ver todos os lances na Sky em agá dê}

A análise de como a letra se encaixa à melodia do jingle traz também evidências relativas a processos fonológicos, que podem ser explorados futuramente, do ponto de vista da interface Música-Linguística. Por exemplo, no primeiro verso, há que se considerar a realização de uma epêntese inicial na palavra $S k y$, para que a letra possa ser adequadamente encaixada na canção:

Nesse edifício / todo mundo tem (i)Sky

O segundo jingle considerado é o da propaganda da rede de supermercados Pão de Açúcar, com o tema O que faz vocêfeliz? A campanha criada pela P.A. Publicidade, agência do Grupo Pão de Açúcar, em 2013, conta com a voz da cantora Clarice Falcão. O Diretor Geral da campanha é Eduardo Romero. ${ }^{3}$

Em (5), apresenta-se a letra do jingle O que faz você feliz, na versão de 30 segundos.

3 Informações disponíveis em: http://www.adnews.com.br/index.php?url=publicidade/clarice-falcao-canta-pela-felicidade-em-campanha-do-pao-de-acucar, acesso em 10 janeiro 2016. 
(5)

$\mathrm{O}$ que faz você feliz?

Você feliz o que é que faz?

Você faz o que te faz feliz?

O que faz você feliz você que faz.

Pra ser feliz

Pra ser feliz

O que você faz pra ser feliz?

Como se pode ver a partir da Tabela 3 , a coincidência entre as proeminências musical e linguística chega a $82.1 \%$; se consideradas as pretônicas nesse cômputo, chega a $85.7 \%$. Estes resultados reforçam os resultados alcançados em relação ao jingle da Sky.

Tabela 3 - Pauta prosódica das sílabas em posição inicial do compasso musical: O que você faz pra ser feliz?

\begin{tabular}{lr}
\hline $\begin{array}{l}\text { Pauta prosódica da sílaba em posição inicial } \\
\text { do compasso musical }\end{array}$ & $\begin{array}{r}\text { quantidade de unidades } \\
\text { de tempo (compassos) }\end{array}$ \\
\hline tônica & $12(42.8 \%)$ \\
\hline monossílabo tônico & $11(39.3 \%)$ \\
\hline monossílabo átono (clítico) & $4(14.3 \%)$ \\
\hline pretônica & $1(3.6 \%)$ \\
\hline átona final & 0 \\
\hline nenhuma sílaba & 0 \\
\hline TOTAL & $28(100 \%)$ \\
\hline
\end{tabular}

Fonte: Elaboração própria.

O mais interessante com relação a este jingle é o fato de os monossílabos átonos se comportarem da mesma maneira que os monossílabos tônicos, recebendo proeminência e sendo cantados como se assim fossem. Este resultado pode indicar evidências a favor de algumas hipóteses há muito aventadas por linguistas:

1. Mattoso Camara Jr. (1985[1970]) considera que os clíticos do PB não se comportam como postônicas, mas como sílabas pretônicas; sendo assim, podem assumir proeminência (musical e linguística), mesmo que secundária; 
2. Bisol (2005[1996], p. 248) mostra que "existem dois tipos de clíticos: os que se comportam junto à palavra de conteúdo como uma só unidade fonológica e os que revelam certa independência, submetendo-se às mesmas regras da palavra fonológica”. Para Bisol, os clíticos do PB são do segundo tipo, pois se submetem à regra de neutralização das vogais átonas finais, independentemente de serem proclíticos ou enclíticos. Isso mostraria sua relativa independência fonológica, o que combina com o fato de poderem assumir proeminência musical.

Também no jingle do Pão de Açúcar, a retração acentual parece estar a favor da manutenção de um padrão de ritmo trocaico, como mostra o exemplo (6), em que a retração acentual na palavra você vem marcada em amarelo. Como mostramos em Massini-Cagliari (1999a), ritmo trocaico é aquele em que as proeminências se sucedem, em um padrão binário de alternância de sílabas fortes/fracas.

O que você faz pra ser feliz?

Em vários dos trabalhos desta autora (Massini-Cagliari, 1999a, 2014), consideramos o pé troqueu silábico como base do ritmo do Português Brasileiro. Em Massini-Cagliari (1999b), mostramos que o conceito de pé tem sido crucial para a descrição da prosódia das línguas, desde a Antiguidade Clássica, sendo que a tradição da nomenclatura adotada para os pés (troqueus, iambos, dáctilos etc.) na teoria fonológica deriva diretamente da metrificação latina.

Por último, apresentamos a análise do jingle Duchas Corona, uma propaganda conhecidíssima as décadas de 70 e 80 do século XX. De autoria de Francis Monte, composto em 1972, foi lançado em 1978 e veiculado até 1983, "fazendo com que a marca virasse sinônimo de ducha de banho" (informações veiculadas pelo canal Agência Cor. Português. Disponível em: https://www. youtube.com/watch?v=LJjLWKuvaRk).

Em (7), apresentamos a letra do jingle, analisada a partir da representação da correlação entre o status prosódico das sílabas linguísticas e as proemi- 
nências musicais (tempo forte do compasso). No caso desse jingle específico, é fácil localizar os momentos de proeminência musical, uma vez que esses são reforçados por palmas. Há que se considerar que se trata de uma melodia curta, que, no intervalo de 33 segundos, é realizada três vezes, com uma pequena variação na letra do segundo verso de cada estrofe. $O$ primeiro e o terceiro versos, por sua vez, permanecem inalterados na letra, em todas as três estrofes.

Apanho o sabonete

Pego uma canção e vou cantando sorridente

Duchas Corona, um banho de alegria num mundo de água quente

Apanho o sabonete

Abro a torneira, de repente a gente sente

Duchas Corona, um banho de alegria num mundo de água quente

Apanho o sabonete

É Duchas Corona dando um banho em tanta gente

Duchas Corona, um banho de alegria num mundo de água quente

A partir da representação em (7), pode-se observar que todos os momentos de proeminências musicais, ou seja, tempos fortes do compasso (no caso, reforçados por palmas, na performance do jingle na propaganda) são ocupadas por sílabas acentuadas de palavras não monossílabas. Neste sentido, este jingle pode ser considerado prototípico, no sentido de coincidência total entre proeminências musicais e linguísticas.

No entanto, para que consideremos que há $100 \%$ de coincidência, devem ser observados alguns fatos.

Por exemplo, na primeira frase musical/textual ("Apanho o sabonete"), representada em (8), há que se considerar que, na palavra "sabonete", a proeminência musical não cai exatamente no momento inicial da enunciação da sílaba, mas na sustentação da duração dessa sílaba (representada, aqui, pela repetição da letra "e" entre hífens). 
Apanho o sabone-e-te

Fenômeno semelhante acontece na frase musical final, relativa ao terceiro verso, nas três estrofes. Na palavra final da estrofe, a proeminência musical coincide com a sílaba tônica da palavra "quente", se considerarmos que a batida forte do compasso se combina com o prolongamento da duração da sílaba “quen”, representada em (9) a partir de três hifens grafados em vermelho.

Duchas Corona, um banho de alegria num mundo de água quen---te

Mesmo quando se consideram as proeminências musicais intermediárias, ou seja, os tempos meio-fortes, a coincidência entre proeminências musicais e linguísticas, no caso deste jingle específico, é alta, como se pode ver em (10). Em apenas dois momentos do primeiro verso das estrofes, que se repete, a proeminência musical não coincide com uma sílaba tônica. Na palavra "sabonete", a proeminência meio-forte do compasso encabeçado pela sílaba tônica de "apanho", coincide com o prolongamento da sílaba pretônica "sa". Além disso, no final deste verso, a proeminência musical meio-forte recai sobre uma pausa. Também é necessário considerar que, no final do terceiro verso, ocorre mais uma vez a coincidência entre a proeminência musical meio-forte e uma pausa, antes da retomada da melodia da segunda e da terceira estrofes e da finalização completa.

Apanho o sa--bone-e-te /

Pego uma canção e vou cantando sorridente

Duchas Corona, um banho de alegria num mundo de água quente /

Apanho o sa--bone-e-te

Abro a torneira, de repente a gente sente

Duchas Corona, um banho de alegria num mundo de água quente /

Apanho o sa--bone-e-te /

É Duchas Corona dando um banho em tanta gente

Duchas Corona, um banho de alegria num mundo de água quente / 
A tabela 4 traz a contabilização das pautas prosódicas das sílabas que ocorrem em posição de proeminência musical forte (posição inicial do compasso) e meio-forte, com relação ao jingle Duchas Corona. Como se pode ver, mesmo quando se consideram as prominências musicais meio-fortes, em 81.25\% dos casos, a proeminência continua a recair sobre sílabas tônicas de palavras de mais de uma sílaba, sendo que em apenas um caso, que se repete duas vezes, totalizando três ocorrências, a proeminência recai sobre o prolongamento de uma sílaba pretônica - no caso, a sílaba pretônica inicial da palavra "sabonete". A este respeito, é importante ressaltar que, como já foi citado anteriormente, Camara Jr. (1970[1985], p. 63) reconhecia a predominância prosódica de sílabas pretônicas sobre átonas finais, conferindo a esse tipo de sílaba uma proeminência "média", quando comparada com as tônicas. Esta percepção de Camara Jr. é corroborada por trabalhos mais recentes, como o de Collischonn (1994).

Tabela 4 - Pauta prosódica das sílabas em posição inicial (forte) e meio-forte do compasso musical: Duchas Corona

\begin{tabular}{lr}
\hline $\begin{array}{l}\text { Pauta prosódica da sílaba em posição } \\
\text { inicial do compasso musical }\end{array}$ & $\begin{array}{r}\text { quantidade de unidades de } \\
\text { tempo (compassos) }\end{array}$ \\
\hline tônica & $39(81.25 \%)$ \\
\hline monossílabo tônico & 0 \\
\hline monossílabo átono (clítico) & 0 \\
\hline pretônica & $3(6.25 \%)$ \\
\hline átona final & 0 \\
\hline nenhuma sílaba & $6(12.5 \%)$ \\
\hline TOTAL & $48(100 \%)$ \\
\hline
\end{tabular}

Fonte: Elaboração própria.

Quando se desconsideram os contextos de coincidência entre proeminência musical com "silêncios linguísticos" (representados na tabela 1 pelas ocorrências de "nenhuma sílaba"), o índice de correspondência entre proeminência musical e linguística sobe para $92.9 \%$ - tabela 5 . 
Tabela 5 - Pauta prosódica das sílabas em posição inicial (forte) e meio-forte do compasso musical: Duchas Corona (desconsiderando a ausência de material linguístico em posição de proeminência musical)

\begin{tabular}{lr}
\hline $\begin{array}{l}\text { Pauta prosódica da sílaba em posição inicial do } \\
\text { compasso musical }\end{array}$ & $\begin{array}{r}\text { quantidade de unidades de tempo } \\
\text { (compassos) }\end{array}$ \\
\hline tônica & $39(92.9 \%)$ \\
\hline monossílabo tônico & 0 \\
\hline monossílabo átono (clítico) & 0 \\
\hline pretônica & $3(7.1 \%)$ \\
\hline átona final & 0 \\
\hline TOTAL & $42(100 \%)$ \\
\hline
\end{tabular}

Fonte: Elaboração própria.

Um último fato interessante a ser observado é a realização do final do jingle, na performance com que ficou famoso, na propaganda das Duchas Corona. $\mathrm{Na}$ terceira realização do verso "Duchas Corona, um banho de alegria num mundo de água quente", no final da propaganda, ocorre um prolongamento da sílaba átona final, que pode ser interpretado como uma marca de final de enunciado fonológico, e que se dá pela utilização estilística da pronúncia da sílaba átona final da palavra "quente", foneticamente realizada como a consoante africada [ $t$ ], não seguida da vogal átona final /i/, que é apagada. Essa realização prolongada da parte fricativa da consoante africada traz uma aproximação com o som da água da ducha anunciada.

\section{Conclusão}

A aproximação entre Música e Linguística, como mostrado na Introdução deste capítulo, já foi objeto de diversos estudos, de variados pontos de vista. Neste contexto, o presente estudo teve como objetivo analisar a relação entre a prosódia musical e a prosódia linguística (entendida em sentido amplo, e não apenas como ortoépia) em jingles de propaganda. Embora o projeto no qual a pesquisa se insere seja amplo, abrangendo diversos gêneros linguísticos/poéticos e musicais, a escolha por estudar inicialmente jingles se deu pela facilidade que colocam, em termos da sua extensão temporal diminuta, e pela consideração de 
que, pela natureza de sua função de propaganda em nossa sociedade, para serem eficazes, não poderiam apresentar uma relação extravagante entre as prosódias dos níveis musical e linguístico, sob pena de comprometer sua própria função.

A análise aqui empreendida de três jingles bastante populares a seu tempo mostrou que, conforme o esperado, em termos de ritmo, há uma forte correlação entre proeminências nos níveis musicais e linguístico (incluindo-se, dentro da concepção de "nível linguístico", o aproveitamento poético das proeminências das palavras na constituição de versos). Conforme apresentado, há pouquíssimos momentos de "subversão" da coincidência entre proeminências musicais e linguísticas, sendo muitos desses contextos explicáveis por razões linguísticas estilísticas (também no sentido de prosódia musical, de Baleiro, 2013). Pelo contrário, conforme foi possível demonstrar, a tendência apresentada nos três casos analisados é reforçar os parâmetros rítmicos do Português Brasileiro na relação entre letra e música, por exemplo, constituindo padrões trocaicos, realçando o caráter de proeminência intermediária das pretônicas, utilizando estilisticamente processos fonológicos correntes na língua (como a epêntese, no jingle da Sky, e o apagamento de vogais, no final do jingle das Duchas Corona) para manutenção do ritmo esperado ou para constituir efeitos poéticos esperados, etc.

Por fim, no que tange ao objetivo mais abrangente da pesquisa desenvolvida por esta pesquisadora e pelo grupo em que se insere, que tem por meta confirmar a possibilidade de uma conexão entre a música e a linguística no desenvolvimento de uma nova metodologia para o estudo da prosódia de línguas atuais ou de períodos anteriores de línguas vivas ou já mortas, este estudo preliminar com jingles buscou iniciar a observação da relação ente ritmo musical e linguístico em gêneros musicais diversos e de épocas diferentes. Do ponto de vista do observado em relação aos três jingles analisados, essa relação se mostrou relevante, tendo sido observada na performance a partir da qual ficaram conhecidos e famosos (no sentido de bem apreciados) pelos usuários da língua. Assim, a partir de estudos como este, espera-se que, no futuro, quando mais estudos desta natureza forem realizados, seja possível validar a extensão do raciocínio a períodos passados da língua, quando ainda não havia a possibilidade tecnológica de registros sonoros, mas dos quais sobreviveram registros escritos, inclusive partituras de músicas para serem cantadas. 


\section{REFERÊNCIAS}

BALEIRO, Z. Esta Dona Prosódia. Piauí. 17/10/2013. https://piaui.folha. uol.com.br/esta-dona-prosodia/\#: :text=Trocando $\% 20 \mathrm{em} \% 20 \mathrm{mi} \% \mathrm{C} 3 \% \mathrm{BA}$ dos\%2C\%20seria\%20a,os\%20acentos\%20da\%20estrutura\%20musical.

Acesso em: 23 ago. 2020.

BENFATTI, M. F. N. Falando em música... Um ensaio sobre o papel dos fenômenos linguísticos em uma epidemiologia de representações musicais. Dissertação (Mestrado em Linguística). Universidade Federal do Paraná, Curitiba, 2010.

BISOL, L. Constituintes prosódicos. In: BISOL, L. (Org.). Introdução a estudos de fonologia do português brasileiro. $4^{\mathrm{a}}$ edição revista e ampliada. Porto Alegre: EDIPUCRS, 2005. p. 243-255. [1ª edição: 1996.]

CAMARA Jr., J. M. Estrutura da língua portuguesa. 15. ed. Petrópolis: Vozes, 1985. [1. ed. 1970].

CÂMARA JR., J. M. Dicionário de filologia e gramática referente à língua portuguesa. 5. ed. Rio de Janeiro: J. Ozon Editor, [1973].

CARMO JR., J. R. Music Phonology. Trabalho apresentado no XXI Congresso da Associação Nacional de Pesquisa e Pós-Graduação em Música. Uberlândia, UFU, 2011.

CARM,O JR., J. R. Sobre a gramática da palavra cantada. Caderno de Estudos Linguísticos. (54.2), Campinas, Jul./Dez. 2012.

CARMO JR., J. R.; SANTOS, R. S. Hierarquia prosódica e hierarquia melódica na canção Gabriela. D.E.L.T.A. São Paulo, 26:2, 2010, 319-343.

Chico: A série. DVD1 Meu caro amigo. Direção de Roberto de Oliveira. [Coleção de DVDs]. (109 minutos), colorido. 
CHOBERT, J.; BESSON, M. Music Expertise and Second Language Learning. Brain Sciences. London, 2013, Jun. 3(2): 923-940.

COLlisCHONN, G. Acento secundário em português. Letras de Hoje. Porto Alegre, v. 29, no 4, p. 43-53, dezembro de 1994.

COSTA, D. S. A interface música e lingüística como instrumental metodológico para o estudo da prosódia do português arcaico. Tese (Doutorado em Linguística e Língua Portuguesa). FCL, UNESP, Araraquara, 2010.

COUPER-KUHLEN, E. An Introduction to English Prosody. London: Edward Arnold, 1986.

COUTINHO, E.; DIBBEN, N. Psychoacoustic cues to emotion in speech prosody and music. Cognition and Emotion, 27:4, 2013, p. 658-684

CURTIS, M. E.; BHARUCHA, J. J. The Minor Third Communicates Sadness in Speech, Mirroring Its Use in Music. Emotion, Medford/Sommerville, v. 10, n. 3, 2010. Disponível em: http://ase.tufts.edu/psychology/music-ognition/pdfs/Curtis\&Bharucha2010Emotion.pdf. Acesso em: 07 Ago. 2014.

DUCHAS Corona Jingle. [S.1.: s.n.], 1978. 1 vídeo (33seg). Publicado pelo canal Agência Cor. Português. Disponível em: https://www.youtube.com/watch?v=LJjLWKuvaRk. Acesso em: 27 ago.2020.

EDIFÍCIO Sky Futebol Comercial HDTV 22s [S.1.: s.n.], 2014. 1 vídeo (30seg). Publicado pelo canal Dulike ¿ Português. Disponível em: https://www. youtube.com/watch?v=JBXtR_HHRCI. Acesso em: 22 jun.2014.

FERREIRA NETTO, W. Fonologia, discurso e interdisciplinaridade. Relações possíveis entre a fonologia e a músicas. In: SEMINÁRIO INTERNACIONAL DE LINGUÍSTICA, 7; CONGRESSO INTERDISCIPLINAR DE CORTESIA, 3; SIMPÓSIO DE LINGUÍSTICA TEXTUAL, 2. Universidade Cruzeiro do Sul, São Paulo, 15/07/2017. DOI: 10.13140/ RG.2.2.31642.54722. 
GELAMO, R. P. Organização prosódica e interpretação de canções: a frase entoacional em quatro diferentes interpretações de $\mathrm{Na}$ Batucada da Vida. Dissertação (Mestrado em Linguística). IBILCE, Unesp, São José do Rio Preto, 2006.

HAYES, B.; KAUN, A. The Role of Phonological Phrasing in Sung and Chanted Verse. (1996): The Linguistic Review 13:243-303.

JACKENDOFF, R.; LERDAHL, F. A Deep Parallel Between Music and Language. Bloomington: Indiana University Linguistics Club, 1980.

LEMOS, C. L.; CARMO JR., J. R.; SHIMODA, L. T. A interação entre expressões na canção: repetições e hierarquia. In: LOPES, I. C.; SOUZA, P. M. (Orgs.) Estudos semióticos do plano da expressão. São Paulo: FFLCH/ USP, 2018, p. 222-241.

LERDAHL, E.; JACKENDOFF, R. A generative theory of tonal music. Cambridge: The MIT Press, 1983.

LIMA, J. G. Ritmo e Melodia no Poema Lido e Musicalizado: Alguns exemplos do repertório brasileiro. Dissertação (Mestrado em Estudos Literários). Universidade Federal do Paraná, Curitiba, 2007.

MACHADO, A. L. Diferenças na percepção de emoções em enunciados verbais declamados e cantados. Dissertação (Mestrado em Linguística e Língua Portuguesa). FCL, Unesp, Araraquara, 2017.

MASSINI-CAGLIARI, G. A música da fala dos trovadores. Desvendando a prosódia medieval. São Paulo: Editora Unesp, 2015.

MASSINI-CAGLIARI, G. Três momentos da história da acentuação portuguesa. Web-Revista SOCIODIALETO; Bach., Lic. Mestrado-Letras UEMS/Campo Grande, v. 4, n. 12, mai. 2014. p. 555-574.

MASSINI-CAGLIARI, G. Contribuição para a análise do ritmo linguístico das cantigas medievais profanas e religiosas a partir de uma interface Música- 
-Linguística. In: REBELO, H. (Coord.) Lusofonia:Tempo de Reciprocidades. Actas do IX Congresso da Associação Internacional de Lusitanistas. Madeira, 4 a 9 de agosto de 2008. Porto: Edições Afrontamento, 2011. Vol. I, p. 41-53.

MASSINI-CAGLIARI, G. From Musical Cadences to Linguistic Prosody: How to Abstract Speech Rhythm of the Past. In: Partridge, J. (Ed.) Interfaces in language. Newcastle upon Tyne: Cambridge Scholars, 2010(a). p. 113-134.

MASSINI-CAGLIARI, G. Sobre as relações entre proeminências musicais e poéticas na poesia trovadoresca profana e religiosa. In: PIRES, A. D.; FERNANDES, M. L. O. Matéria de poesia. Crítica e criação. Araraquara : FCL-UNESP Laboratório Editorial; São Paulo: Cultura Acadêmica. p. 47-66.

MASSINI-CAGLIARI, G. Fonologia Histórica: estudando o ritmo lingüístico a partir de uma interface Lingüística-Música. In Hora, Dermeval da (Org.) Anais - VI Congresso Internacional da Abralin. João Pessoa: Idéia, 2009. p. 1683- 1692 .

MASSINI-CAGLIARI, G. Das cadências musicais para o ritmo lingüístico: Uma análise do ritmo do Português Arcaico, a partir da notação musical das Cantigas de Santa Maria. Revista da ABRALIN, v. 7, n. 1, p. 9-26, jan./jun. 2008(a).

MASSINI-CAGLIARI, G. Interface Fonologia-Poesia-Música: Uma análise do ritmo lingüístico do Português Arcaico, a partir da notação musical das Cantigas de Santa Maria. Estudos Lingüísticos. São José do Rio Preto: GEL, 2008(b). vol. 37, n.1, p. 9-20.

MASSINI-CAGLIARI, G. Do poético ao lingüístico no ritmo dos trovadores: três momentos da história do acento. Araraquara: FCL, Laboratório Editorial, UNESP; São Paulo: Cultura Acadêmica, 1999a.

MASSINI-CAGLIARI, G. Sobre o percurso histórico da acentuação em Português. In: SCARPA, E. M. (Org.). Estudos de Prosódia. Campinas: Ed. da UNICAMP, 1999b. p. 141-187. 
MASSINI-CAGLIARI, G.; CAGLIARI, L. C. Fonética. In: MUSSALIM, F.; BENTES, A. C. (Org.). Introdução à Lingüística: domínios e fronteiras. São Paulo: Cortez, 2001. v. 1, p. 105-146.

MATEUS, M. H. M. Uma vida cheia de palavras. Lisboa: Colibri, 2018.

MEDEIROS, B. R. de. Descrição comparativa de aspectos fonético-acústicos selecionados da fala e do canto em português brasileiro. Tese (Doutorado em Linguística). IEL, Unicamp, Campinas, 2002.

PACHECO, A. (Org.) Actas do Simpósio A Pronúncia do Português Europeu Cantado. Lisboa: Caravelas - Núcleo de Estudos da História da Música Luso-Brasileira; CESEM - Centro de Estudos de Sociologia e Estética Musical; FCSH, Universidade Nova de Lisboa, 2009.

PÃO de açúcar. O que faz você feliz comercial 1080i (HDTV) [S.l.: s.n.], 2014. 1 vídeo (30seg). Publicado pelo canal JW R. Português. Disponível em: https://www.youtube.com/watch?v=e8wFwOvttsg. Acesso em: 22 jun.2014.

SCARPA, E. M. Apresentação. In: SCARPA, E. M. (Org.). Estudos de prosódia. Campinas: Editora da UNICAMP, 1999. p. 7-17.

SLOBODA, J. A. A mente musical. A Psicologia cognitiva da música. Londrina: EdUEL, 2008.

SOUZA, A. R. de. A intenção na melodia: estudo interdisciplinar sobre as relações entre entoação e gênero do discurso nas manifestações vocais (da fala ao canto). Tese (Doutorado em Filologia e Língua Portuguesa). FFLCH, USP, São Paulo, 2014.

TATIT, L. Semiótica da canção: melodia e letra. $3^{a}$ edição. São Paulo: Editora Escuta, 2007. 
TATIT, L.; LOPES, I. Elos de melodia e letra: análise semiótica de seis canções. Cotia: Ateliê Editorial, 2008.

TRASK, R. L. Dicionário de linguagem e lingüística. Tradução e adaptação de Rodolfo Ilari. São Paulo: Contexto, 2004.

XAVIER, M. F.; MATEUS, M. H. M. (Org.). Dicionário de termos lingüísticos. Lisboa: Cosmos, 1990. v. 1. 


\section{HIPERSEGMENTAÇÃO E PROSÓDIA: UM ESTUDO DAS FORMAS HIPERSEGMENTADAS DOS ADVÉRBIOS EM -MENTE EM REDAÇÕES ESCOLARES}

Ana Carolina Freitas Gentil Almeida Cangemi

Thais Holanda de Abreu-Zorzi

\section{Introdução}

Neste trabalho, apresentamos nosso estudo sobre a relação entre casos de hipersegmentação e aspectos prosódicos em redações escolares que fazem parte do projeto de Extensão Universitária ${ }^{1}$ organizado pela Prof. ${ }^{a}$ Dr. $^{\text {a }}$ Luciani Tenani, docente da Universidade Estadual Paulista "Júlio de Mesquita Filho", Câmpus de São José do Rio Preto.

Em relação à hipersegmentação, entendemos como um processo linguístico que pode ocorrer durante a produção de textos e que está relacionado ao fato de as palavras escritas apresentarem fronteiras gráficas (espaço em branco ou hífen), as quais, por sua vez, não seguem as convenções ortográficas de uma língua. Em nosso estudo, observamos a ausencia, então, dessas relacionadas ao português brasileiro.

A partir da observação e do mapeamento das ausência e presença de fronteiras gráficas, quantificamos e discutimos os resultados à luz da Teoria Prosódica (NESPOR; VOGEL, 2007 [1986]). O modelo teórico foi adotado, em detrimento de outro(s), para manter coerência com as análises desenvolvidas atualmente no português brasileiro ${ }^{2}$.

1 O referido projeto foi realizado com a participação de 662 alunos dos últimos quatro anos do Ensino Fundamental de escolas da rede pública de ensino da cidade de São José do Rio Preto/ SP. As redações foram coletadas e organizadas pela professora Dra. Luciani Tenani, a quem agradecemos imensamente o apoio ao permitir acesso a esse banco de dados tão produtivo em material linguístico.

2 Conferir os trabalhos de Tenani (2016 e 2014). 
Convém ressaltar também a organização deste artigo. Iniciamos com a apresentação teórica adotada, o corpus e a metodologia. Caminhando para o final, apresentamos os resultados e as referências bibliográficas.

\section{Embasamento teórico}

Baseada no estudo de Abaurre (1991) e em pesquisas desenvolvidas, Tenani (2016, p. 13, aspas da autora) afirma que, no português brasileiro, as segmentações não-convencionais de palavras

são de dois tipos: espaço em branco, caracterizado por ausência de marca gráfica entre palavras, e hífen, caracterizado por um traço entre palavras. As segmentações não-convencionais de palavra podem ser classificadas em dois tipos principais: hipossegmentação, quando estão ausentes as fronteiras gráficas entre palavras, como em "concerteza", "ajudime"; e hipersegmentação, quando estão presentes as fronteiras gráficas dentro de uma palavra ortográfica, como em "na quela”, "morava-mos".

De acordo ainda com Tenani (2016), as segmentações não-convencionais de palavra evidenciam o fato de que as convenções de fronteiras de palavra na escrita não correspondem a fronteiras de constituintes prosódicos (especialmente palavra fonológica - $\mathrm{\omega}$ ), que se configuram com base em critérios rítmicos e entoacionais e que guiam (em certa medida) os alunos do EF a segmentarem seus textos em unidades distintas daquelas adotadas pelas convenções ortográficas.

Logo, os pressupostos da Fonologia Prosódica (Selkirk, 1980; Nespor; Vogel, 2007 [1986]; Vigário, 2001; Nespor; Guasti, 2002; Cunha; Miranda, 2009 ) se mostraram mais adequados à descrição e análise das formas hipersegmentadas dos advérbios em -mente nas redações produzidas por alunos do Ensino Fundamental II no Português Brasileiro (PB).

Ademais, foram utilizadas as teorias que analisam a hipersegmentação do ponto de vista ortográfico, sobretudo relacionadas a rasuras (Calil; Felipeto, 2000; Chacon, 2014; Capristano; Machado, 2015). 


\subsection{Fonologia prosódica}

[...] a suprasegmental, hierarchically arranged organization to the utterance, not a simple linear arrangement of segments and boundaries. (Selkirk, 1980, p. 1)

A fonologia prosódica teve início com o trabalho de Selkirk (1980), o qual propôs uma teoria fonológica não-linear embasada em uma organização hierárquica dos níveis gramaticais acima da sílaba. Segundo Selkirk (1980, p.1), essa organização hierárquica é denominada estrutura prosódica, a qual é organizada em constituintes. Todo constituinte, de acordo com Bisol (1996, p.243) pressupõe um cabeça e um ou mais dominados. É assim que surge a ideia de hierarquia dos constituintes dentro da Fonologia Prosódica. Por exemplo, o elemento prosódico pé $(\Sigma)$ domina o elemento imediatamente inferior na categoria prosódica (a sílaba) e assim sucessivamente, conforme mostra o Quadro 1:

Quadro 1- Constituintes prosódicos segundo proposta de Selkirk (1980)

\begin{tabular}{|c|c|c|}
\hline \multicolumn{3}{|c|}{ Proposta de Selkirk (1980) } \\
\hline \multicolumn{2}{|c|}{ CONSTITUINTES PROSÓDICOS } \\
\hline constituintes & tradução & símbolos \\
\hline phonological utterance & enunciado fonológico & $\mathrm{U}$ \\
\hline intonational phrase & grupo entoacional & $\mathrm{I}$ \\
\hline phonological phrase & grupo fonológico & $\Phi$ \\
\hline phonological word & palavra fonológica & $\omega$ \\
\hline foot & pé & $\Sigma$ \\
\hline syllable & sílaba & $\sigma$ \\
\hline
\end{tabular}

Fonte: adaptado de Selkirk (1980).

A partir do estudo de Selkirk (1980), surgiram outros trabalhos na área da fonologia prosódica, os quais revisaram e adaptaram o modelo teórico inicial as especificidades e necessidades de cada língua descrita.

3 Tradução: "uma organização suprassegmental arranjada hierarquicamente para o enunciado, não um simples arranjo linear de segmentos e fronteiras". 
Um desses trabalhos é o de Nespor e Vogel (2007 [1986]), modelo teórico seguido neste estudo. Assim como Selkirk (1980), as autoras propuseram uma organização hierárquica dos níveis gramaticais que estariam acima da sílaba, porém, com o acréscimo de mais um constituinte prosódico (o grupo clítico), conforme mostra o Quadro 2:

Quadro 2 - Constituintes prosódicos segundo proposta de Nespor e Vogel (1986)

\begin{tabular}{|c|c|c|}
\hline \multicolumn{3}{|c|}{ Proposta de Nespor e Vogel (1986) } \\
\hline \multicolumn{2}{|c|}{ CONSTITUINTES PROSÓDICOS } \\
\hline domínios & tradução & símbolos \\
\hline syllable & sílaba & $\sigma$ \\
\hline foot & pé & $\Sigma$ \\
\hline phonological word & palavra fonológica & $\omega$ \\
\hline clitic group & grupo clítico & $\mathrm{C}$ \\
\hline phonological phrase & grupo fonológico & $\Phi$ \\
\hline intonational phrase & grupo entoacional & $\mathrm{I}$ \\
\hline phonological utterance & enunciado fonológico & $\mathrm{U}$ \\
\hline
\end{tabular}

Fonte: Adaptado de Nespor e Vogel (1986, p.16).

Ademais, as autoras propuseram para essa teoria um estudo da relação da estrutura fonológica com a sintaxe. Em trabalho anterior - Nespor e Vogel (1982) - observaram que, na gramática gerativista desenvolvida por Chomsky e Halle (1968), as regras fonológicas não se relacionavam com a estrutura sintática, isto é, os componentes sintáticos e fonológicos eram independentes. No entanto, Nespor e Vogel (2007 [1986]) observam que a estrutura prosódica é determinada, parcialmente, pela estrutura sintática, isto é, as regras fonológicas podem sim se relacionar com a estrutura sintática em alguns casos. Algumas vezes ambas não coincidem; em outras, coincidem. Sendo assim, o quadro exposto anteriormente, pode ser representado ainda por meio da seguinte estrutura, a qual estabelece por meio de uma escala de dominios fonológicos 
crescente, do menor constituinte prosódico estipulado ao maior, sete unidades que compõem uma hierarquia prosódica:
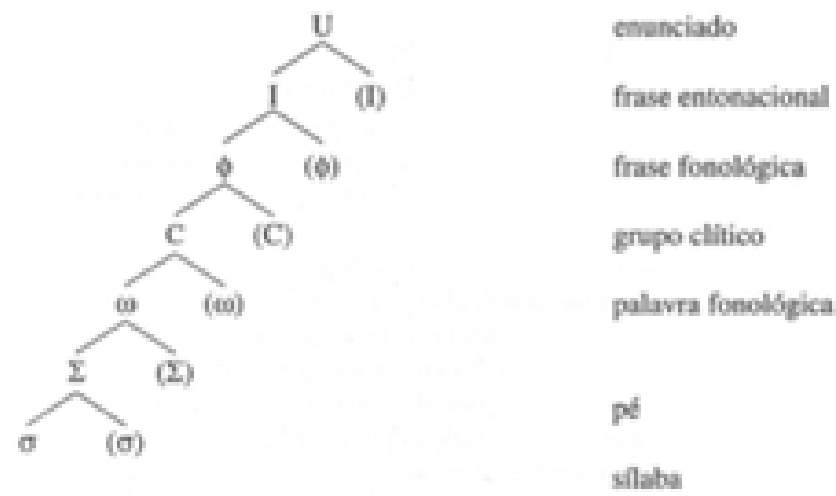

Cada domínio é constituído por meio de aplicação das regras fonológicas. A relação entre a estrutura sintática e a prosódica é dada por um mapeamento sintático-fonológico que fornece uma representação prosódica que, posteriormente, pertence a um dos niveis da hierarquia dos constituintes prosódicos. Outro aspecto importante a ser ressaltado sobre essa teoria é sua constituição hierárquica. Há os constituintes e, em cada um deles, pressupõemse um “cabeça do constituintes", e um ou mais dominados. ${ }^{4}$

Muito embora a hierarquia prosódica seja composta por sete domínios, neste artigo, o nível prosódico privilegiado é a palavra fonológica, uma vez que, a partir de o mapeamento dos dados, mostrou-se relevante para a hipersegmentação.

\subsubsection{A palavra fonológica e o processo de hipersegmentação}

As segmentações não-convencionais de palavra (hipo e hipersegmentação) evidenciam o fato de que as convenções de fronteiras de palavra na escrita, não correspondem a fronteiras de constituintes prosódicos (especialmente $\square$ ).

4 Para mais informações sobre a constituição de domínios prosódicos, indicamos o trabalho de Nespor e Vogel (2007 [1986]). 
Sendo assim, ao enfatizarmos o constituinte da palavra fonológica, conseguimos determinar o "ponto de corte" dos advérbios em -mente hipersegmentados.

Sobre essa relação entre fonologia e morfologia, Nespor e Vogel (1986, p.109) afirmam que "[...] the phonological word ( $\omega$ ) represents the interaction between the phonological and the morphological components of the grammar.

Além disso, destaca-se que a palavra fonológica ( $($ ) é o constituinte prosódico que leva em consideração a proeminência do acento. Segundo Selkirk (1980, p.14), "[...] the $\mathrm{\omega}$ is a category of prosodic structure [...] giving rise to the proper patterns of stress prominence".

Vigário (2001, p.23) também apresenta o mesmo critério de definição para ๑: "A prosodic word must bear one and only one (word) primary stress". Portanto, uma palavra prosódica é o constituinte que possui um acento de palavra, independentemente se aquela coincide ou não com uma palavra morfológica ou palavra gramatical, como mostram os exemplos a seguir:

(1) da quela $(\mathrm{x}$.

(2) tranquila mente

$$
(\mathrm{x} .)(\mathrm{x} .)
$$

No exemplo (1) exposto anteriormente, observa-se que em da quela que o que é segmentado à direita é uma palavra fonológica sem significado lexical, assim considerada por formar um pé métrico. Logo, tal exemplo mostra uma palavra fonológica que não coincide com uma palavra morfológica. Por outro lado, em (2) constata-se que há duas palavras fonológicas (tranquila e mente), as quais também podem ser consideradas palavras morfológicas, pois a primeira seria um adjetivo feminino, e a segunda o "sufixo" ${ }^{8}$ derivacional de advérbios em -mente.

5 Tradução: “[...] a palavra fonológica ( $($ ) representa a interação entre os componentes fonológicos e morfológicos da gramática).”

6 Tradução: "[...] a $\omega$ é uma categoria da estrutura prosódica [...] dando origem a padrões próprios de proeminência do acento."

7 Tradução: "A palavra prosódica deve ter um e apenas um acento primário (de palavra).”

8 Abreu-Zorzi (2016) realiza uma discussão sobre o estatuto prosódico dos advérbios em mente e chega à conclusão de que, do ponto de vista prosódico, -mente não seria um sufixo, mas sim uma palavra fonológica com estatuto independente, uma vez que forma uma pé métrico, apresentando uma proeminência. 
Tomando como base o tipo de palavra, Cunha e Miranda (2009) propõem alguns critérios para a descrição e análise das segmentações não-convencionais do Português. Segundo as autoras, as hipo e hipersegmentações podem ocorrer de acordo com as seguintes estruturas:

a) Palavra gramatical + palavra fonológica: há uma tendência a apresentar à direita da estrutura uma palavra fonológica que coincida ou não com uma palavra lexical. Em se tratando de hipersegmentação, as autoras constataram que, do ponto de vista prosódico, as formas hipersegmentadas apresentam duas estruturas distintas. A primeira delas revela que à direita da segmentação tem-se uma palavra fonológica que coincide com uma palavra lexical, como em a onde (para aonde), na mora (para namora) e da nada (para danada). A segunda, revela que o que é segmentado à direita é uma palavra fonológica sem significado lexical, assim considerada por formar um pé métrico, a saber com migo (para comigo)

b) Palavra fonológica + palavra gramatical: nessa estrutura, há uma tendência ao isolamento da palavra gramatical à direita, como em gritan do (para gritando) e tu do (para tudo).

c) Palavra gramatical + palavra gramatical: não foram observados pelas autoras casos que se enquadrassem nessa estrutura.

d) Palavra fonológica + palavra fonológica: segundo Cunha e Miranda (2009), é possível observar três possibilidades de resultados para essa estrutura: (1) uma palavra fonológica transformando-se em duas que não têm significado na língua (verda deiro, para verdadeiro), (2) uma palavra fonológica transformando-se em duas palavras lexicais (ter mina para termina) e (3) uma palavra fonológica transformando-se em uma palavra lexical e outra sem significado (chapéu sinho para chapeuzinho ${ }^{9}$ ).

9 Deve-se ressaltar que tal exemplo pode ser repensado no que tange à questão de -zinho ser uma palavra lexical sem significado. Em sua dissertação, Abreu (2012) realiza uma ampla discussão a fim de mostrar que -zinho, assim como -inho, são dois elementos que, além de denotarem pequenez, trazem inerente a eles uma conotação de afetividade ou pejoratividade. Sendo assim, chapéu é uma palavra fonológica e -zinho, segundo Abreu (2012), tem um significado inerente a ele e também pode ser considerado uma palavra fonológica que coincide com uma palavra lexical, uma vez que forma um pé métrico e, consequentemente, possui uma proeminência prosódica. Um outro exemplo que ilustraria esse caso seria o da hipersegmentação com pleto (para completo), no qual com é uma palavra lexical e pleto uma palavra sem significado. 
Após a análise dos dados, Cunha e Miranda (2009, p. 146) chegam à conclusão de que nos dados de hipersegmentação, duas tendências prevaleceram: a separação de uma palavra em duas, uma gramatical e outra fonológica, e a separação de uma palavra em duas outras fonológicas. No caso de nosso estudo, a estrutura palavra gramatical + palavra fonológica é predominante, como poderá ser constatado com mais detalhes na subseção de descrição e análise dos resultados. No entanto, há uma ocorrência (prova velmente) que não se encaixa nas estruturas propostas por Cunha e Miranda (2009). Para tentar descrevê-la, utilizamos alguns estudos que propõem a relação entre foco semântico e a proeminência fonológica principal da sentença ${ }^{10}$. Dentre eles, citamos o de Nespor e Guasti (2002) e Fernandes (2007).

Além disso, outra ocorrência não se encaixaria na descrição realizada por Cunha e Miranda (2009); seria a forma hipersegmentada completfa)mente. Para essa forma, foi necessário nos embasarmos em teorias que consideram a hipersegmentação do ponto de vista ortográfico, sobretudo aquelas relacionadas as rasuras.

\subsection{As rasuras no processo de hipersegmentação}

Diversos estudos descrevem o fenômeno da hipersegmentação tomando como base critérios relacionados à ortografia, em especial às rasuras. Um desses trabalhos é o de Capristano e Machado (2015). Nele, as autoras têm o intuito de investigar rasuras ligadas à segmentação de palavras encontradas em enunciados escritos produzidos por crianças ao longo de quatro anos do Ensino Fundamental I. Essas rasuras são interpretadas como pistas de conflitos vividos pelas crianças na aquisição da escrita para identificar as fronteiras da palavra (orto)gráfica. Em outras palavras, é possível afirmar que o conflito vivenciado pelas crianças no momento de segmentar as palavras é motivado, muitas vezes, por um discurso recorrente na sala de aula, em situações nas quais o aluno se vê diante de duas possibilidades de segmentação. Logo,

$\overline{10}$ Segundo Fernandes (2007, p.21), o termo foco "é empregado na literatura lingüística no mínimo com dois sentidos diferentes: ele pode carregar a informação nova no discurso (ou sentença) e pode também funcionar como operador expressando identificação". Ademais, tais noções se referem, respectivamente, ao foco de escopo largo e ao foco de escopo estreito. Para saber mais a respeito, indicamos Fernandes (2007). 
a inserção das crianças em práticas letradas, em especial aquelas institucionalizadas pela escola, têm, sim, efeitos para os conflitos sobre como segmentar. A gradual participação das crianças nessas práticas faz com que elas aproximem-se cada vez mais das formas canônicas de segmentar e, ao mesmo tempo, abandonem e/ou esqueçam os modos não convencionais de distribuir os espaços em branco que delimitam a palavra (orto)gráfica. (Capristano; Machado, 2015, p. 218).

Outro estudo que considera a relação entre rasura e segmentação é o de Calil e Felipeto (2000). Nesse trabalho, os autores apresentam as reflexões sobre o assunto feitas por grande parte dos estudos que investigam a segmentação. Segundo Calil e Felipeto (2000), as pesquisas na área de Aquisição de Linguagem Escrita estão inseridas em um quadro teórico enunciativo, no qual as rasuras aparecem enquanto condição da existência de operações metalinguísticas. Para falar sobre tais operações, os autores expõem a discussão de Fabre (1987) sobre os textos escritos por alunos dos primeiros anos escolares. Segundo Fabre, tais textos apresentam rasuras que assinalam uma atitude, por meio de atividades metalinguísticas e metadiscursivas, de interrogação e de adequação daquele que escreve sobre o texto que está escrevendo. Partindo dessa consideração, aponta quatro operações "metalinguísticas», a citar: supressão, substituição, deslocamento e adição.

Na supressão, o termo escolhido é riscado, rasurado e não substituído: são rasuras não produtivas que traduziriam o abandono da «capacidade inventiva» do escritor.

$\mathrm{Na}$ substituição, um termo é trocado seja por ele mesmo, seja por outro. Quando um termo é eliminado e volta novamente, esta incerteza deixa claro, segundo Fabre, a dificuldade do escritor novato em "escolher" o melhor.

O deslocamento é a terceira operação metalinguística na qual grafemas, sílabas ou palavras inteiras são antecipadas ou repetidas. $\mathrm{O}$ autor traz como exemplo o texto «un p tout petit hippotanes...". Nele o "p" seria uma antecipação de „peti!“, justificando tal antecipação pelo fato de que possivelmente a motricidade da mão em escritores novatos é menos rápido que a palavra internalizada. 
Por fim, nas adições, há o acréscimo de termos ou expressões depois de já se ter escrito algo. É uma operação muito difícil para os alunos que ainda têm pouca experiência com a escrita, uma vez que demanda uma consciência linguística um pouco maior.

Calil e Felipeto (2000) não concordam com o fato de que as rasuras sejam apenas uma operação metalinguística que indicaria um conhecimento sobre os usos e as funções da língua. De acordo com os autores, restringir o processo de rasuramento à motricidade, à internalização ou à motivação parece anular um fato que é de ordem linguística.

Portanto, para os autores o processo de rasura/segmentação das palavras não se resume a questões metalinguísticas, uma vez que é necessário analisar o contexto de produção de tais rasuras, levando em consideração "a singularidade de um sujeito inevitavelmente habitado pela língua”.

Para isso, Calil e Felipeto (2000) utilizam como metodologia da descrição de rasuras a análise da situação na qual essas foram produzidas, ou seja, observam e gravam a criança produzindo um texto a fim de avaliarem o aluno no momento de ressignificação de seu próprio dizer. A partir dessa metodologia, os autores, acreditam que, assim como Capristano e Machado (2015), o aluno rasura mais pela motivação de um discurso recorrente em sala de aula do que pela consciência linguística, principalmente nos anos iniciais do Ensino Fundamental. Eles não negam a existência das operações metalinguísticas propostas por outros estudos, porém pensam que a rasura não ocorre somente por isso. Sendo assim, afirmam que

poderíamos dizer que, se as quatro megaoperações ajudam a descrever o fenômeno, não podem, todavia, interpretá-lo. Igualmente, não permitem generalizações, pois tropeçam na singularidade de um sujeito inevitavelmente habitado pela língua. Aqui tentamos ir além das descrições e generalizações de tais operações e buscar compreender a rasura presente no processo de escritura levando em conta um sujeito que habita a língua e é por ela estruturado. (Calil; Felipeto, 2000, p.108) 


\section{Corpus}

Para a descrição e análise de formas hipersegmentadas dos advérbios em - mente no PB, elegeu-se como corpus de pesquisa 5519 redações escolares produzidas por alunos do ciclo II do Ensino Fundamental, a saber $6^{\circ}, 7^{\circ}, 8^{\circ}$ e 90 anos. Tais redações estão disponibilizadas na forma digital (http://www. convenios.grupogbd.com/redacoes/Login) em um Banco de Dados de Escrita do Ensino Fundamental $I I^{11}$, de acesso restrito a docentes e pesquisadores ${ }^{12}$.

Figura 1. Trecho redação $6^{\circ}$ ano

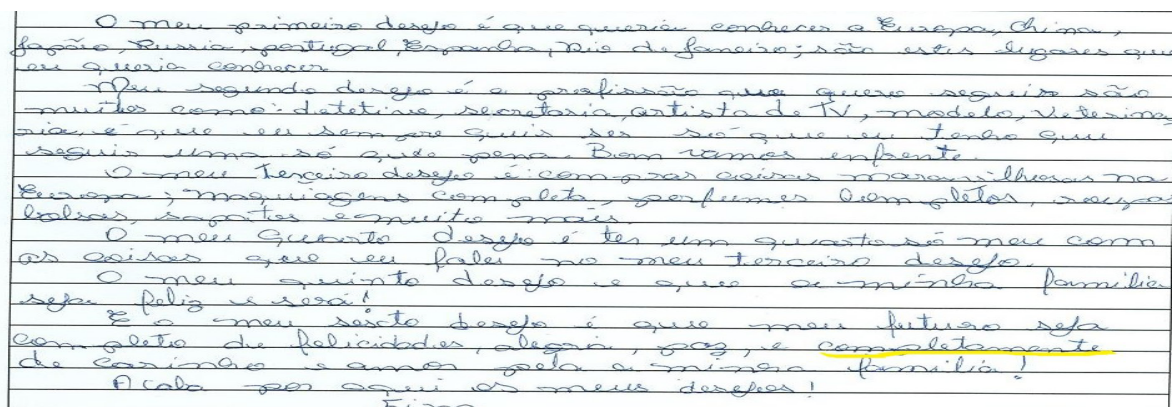

Fonte: Banco de Dados de Escrita do Ensino Fundamental II

Figura 2. Redação $7^{\circ}$ ano

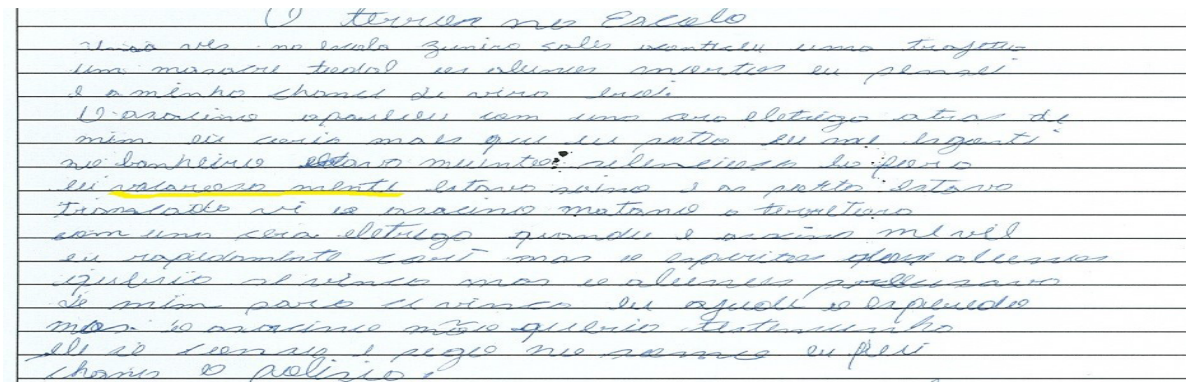

Fonte: Banco de Dados de Escrita do Ensino Fundamental II

${ }^{11} \mathrm{O}$ banco de dados é constituído por 5.519 textos escritos por 662 alunos dos últimos quatro anos do Ensino Fundamental, coletados e organizados pela Prof. ${ }^{a}$ Dr. ${ }^{a}$ Luciani Tenani, docente da Universidade Estadual Paulista “Júlio de Mesquita Filho", Câmpus de São José do Rio Preto, por meio de auxílio a projetos de pesquisas financiados pela Fundação de Amparo à Pesquisa do Estado de São Paulo, FAPESP (Processos 2009/14848-6 e 2013/14546-5).

12 A produção dos textos foi realizada durante um projeto de extensão universitária da Unesp - Desenvolvimento de oficinas pedagógicas de leitura, interpretação e produção textual no Ensino Fundamental. $\mathrm{O}$ projeto teve duração de quatro anos (2008-2011) e era composto por oficinas pedagógicas de leitura, interpretação e produção de textos em uma escola pública do interior do Estado de São Paulo. 
Figura 3. Redação $8^{\circ}$ ano

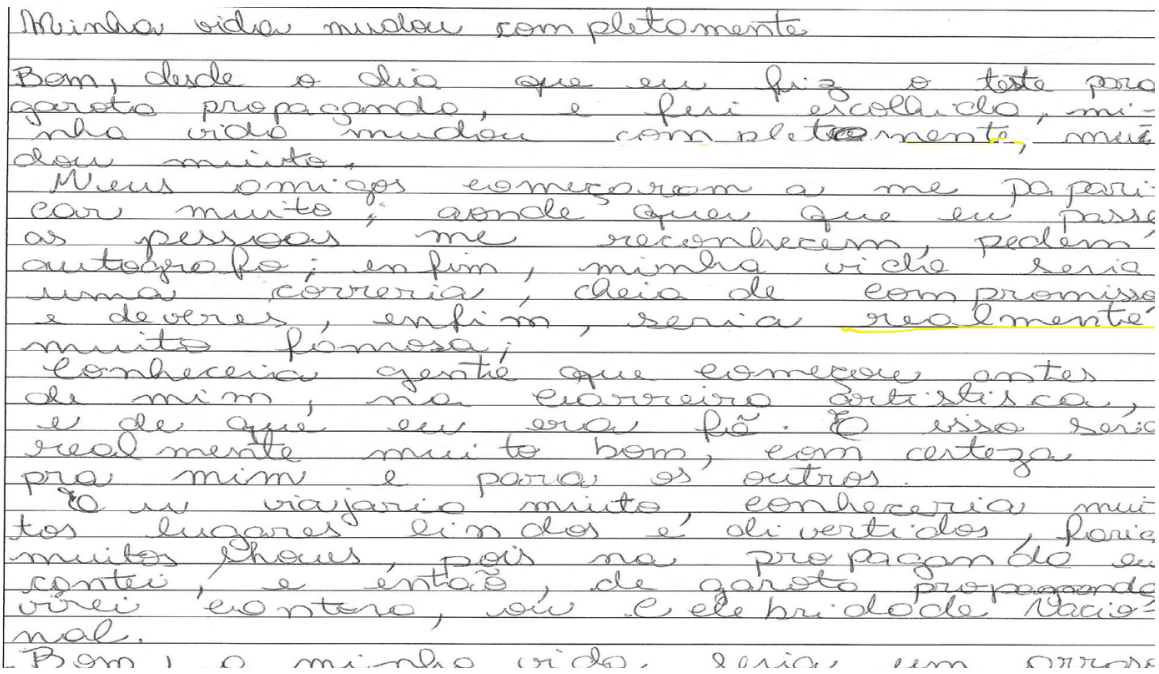

Fonte: Banco de Dados de Escrita do Ensino Fundamental II

Figura 4. Redação 9o ano

Säo fosé do hio Recto, 15 de moic de 2.011
Cano Hroncisco,

Im resposta a sua corta, agradecemos pelo sua sensitilid de emquestaó ia trogedia que acontecev comos usiancas do Rio. Provavelmente muitas crionsos do 3 rosil inteiro ficesem com teauma. medo do ambiente escobs. Em postivulor ev também figuricom medo deir i eccolo, mesmo sendo em outro estado. Nlos como sempse tem um $3580-$ pato prear repetir a acōo de um mal-indrviduo, ev imeus cotegos fi.

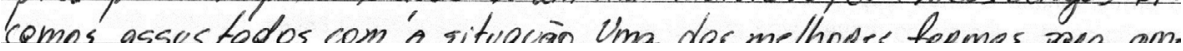
Fonte: Banco de Dados de Escrita do Ensino Fundamental II

A pertinência em considerar as redações do banco de dados, como corpus, reafirma a solidez e a seriedade do projeto de extensão universitária desenvolvido na Unesp. Apropriamo-nos do propósito de Tenani e LonghinThomazi (2014), ou seja, da reflexão sobre os "problemas" de escrita e verificamos a relação entre limites prosódicos e as formas hipersegmentadas dos advérbios em -mente que têm, como resultado, as escritas não convencionais. 
Apesar de os textos integrantes do banco de dados escolhido para compor o nosso corpus de pesquisa não serem produzidos nas séries iniciais do Ensino Fundamental I e não revelarem situações de escrita espontânea, esses apontam para a oralidade, uma vez que as crianças e adolescentes em fase de aprendizagem da escrita ainda não estão totalmente influenciados por esta, percebendo a fala como um contínuo e transpondo tal percepção para a escrita. Os aprendizes segmentam as palavras utilizando uma forma não convencional (quer hiper ou hiposegmentação).

Os textos escritos do 6 ao $9^{\circ}$ anos, frequentemente, oferecem dados relevantes para a análise dos processos de segmentação da palavra. Segundo Abaurre (1991, p.205), na elaboração de um texto escrito, a criança "será chamada a (re)construir a linguagem através de sua transposição para a forma de representação escrita". Sendo assim, o aprendiz testa diversos critérios possíveis para resolver problemas, sobretudo os relacionados à segmentação não-convencional das palavras.

A respeito ainda da instabilidade da escrita nos textos espontâneos iniciais, Abaurre (2002) afirma que, em crianças, as propostas de segmentação da escrita podem ser baseadas em critérios semânticos, fonéticos ou até mesmo da observação da própria escrita. Há, também, critérios que podem se manifestar simultaneamente permitindo à criança operar sobre a língua de forma a resolver localisticamente, segundo o critério que lhe parecer mais adequado a cada instante, de acordo com os numerosos problemas que a escrita 1he vai oferecendo. Cunha e Miranda (2009) apresentam opinião semelhante à de Abaurre (2002) sobre o fato de a segmentação em textos das crianças estar relacionada à experimentação, a testes, com o intuito de resolver segmentações.

Considerando os estudos científicos, a argumentação adotada e os resultados obtidos pelos autores acima referenciados, entendemos que a escrita de textos dos Ciclos I e II do EF se mostra adequada ao estudo de fenômenos de hipo e hipersegmentação. Neste trabalho, propomo-nos a mapear e analisar, especificamente, casos de hipersegmentação dos advérbios em -mente no Ciclo II. 


\section{Metodologia}

Os dados coletados foram analisados qualitativa e quantitativamente. Com relação à abordagem quantitativa, foi realizado, em um primeiro momento, um levantamento das ocorrências de advérbios em -mente que apresentaram o processo de hipersegmentação. Como falantes nativas, não precisamos checar em dicionários a existência das palavras autônomas após o levantamento. No entanto, didaticamente, um segundo passo seria checar a possibilidade de as formas encontradas serem aceitas como autônomas na língua a fim de confirmar o quanto as convenções ortográficas exercem um papel importante no momento de o aprendiz pensar sobre o espaço em branco entre as palavras.

Sobre a questão desse espaço em branco, é preciso ressaltar os trabalhos de Abaurre (1991) e Abaurre e Silva (1993). Em ambos é demonstrado que os espaçamentos entre as palavras no processo de aquisição da escrita é de suma importância para o entendimento do funcionamento da língua. Quando a criança “testa” as possibilidades de segmentar uma palavra, muitas vezes ela está tentando se adequar a uma prática da convenção social a qual foi exposta desde muito cedo:

Ao adquirir a escrita, a criança testa hipóteses já construídas acerca desse sistema. Pode-se pensar então que, mesmo antes de entrar para a escola, o aprendiz, graças às práticas de letramento às quais está exposto cotidianamente, já construiu suas hipóteses no que diz respeito à segmentação da escrita (Abaurre, 1991, grifo nosso, p. 10).

Abaurre e Silva (1993) ressaltam que em termos de escrita, a discussão dos critérios de segmentação dos enunciados deve levar em conta os critérios morfológicos de segmentação que estão na base de muitos sistemas alfabéticos de escrita, segundo os quais deve-se colocar um espaço em branco entre cada unidade linguística com status de palavra autônoma. Segundo os autores,

uma vez que, quando começam a elaborar hipóteses sobre o funcionamento desses sistemas de escrita, as crianças já estão contemplando e manipulando 
material escrito, é mais do que provável que elas, nesse momento, já estejam tomando muitas das suas decisões sobre onde colocar os espaços em branco nas escritas que produzem com base na observação de dados representativos da escrita adulta. (Abaurre; Silva, 1993, p. 089).

Quantitativamente, ainda, é preciso destacar que consideramos as formas adverbiais em -mente hipersegmentadas que ocorreram pelo menos uma vez no corpus. Na perspectiva adotada, a presença de um dado que aparece uma única vez pode apontar para evidências dos limites entre as possibilidades e as impossibilidades da língua; por esse motivo, pode ser crucial na determinação da estrutura prosódica/rítmica/morfossintática dessa língua.

Com relação à abordagem quantitativa, foi feito um levantamento da ocorrência que apresentou o processo de hipersegmentação e dos fenômenos prosódicos, rítmicos e morfossintáticos associados a esse processo. Portanto, os resultados foram analisados tanto quantitativamente, quanto qualitativamente; porém, o objetivo principal é realizar análises sobretudo de cunho qualitativo. A proposta do estudo desenvolvido por esta bolsista corresponde ao desenvolvimento de uma descrição sincrônica do momento atual da língua.

A fim de realizar tal descrição, foi feito, em um primeiro momento, o levantamento das formas hipersegmentadas dos advérbios em -mente nas redações produzidas pelos alunos dos $6^{\mathrm{o}_{\mathrm{s}}}, 7^{\mathrm{os}_{\mathrm{s}}}, 8^{\mathrm{os}_{\mathrm{s}}}$ e $9^{\mathrm{o}_{\mathrm{s}}}$ anos do Ensino Fundamental II. Para isso, utilizamos como parâmetro de busca no sistema Textus o critério Série, já que o fenômeno investigado (a hipersegmentação), como já discutido na subseção anterior, tem maior probabilidade de ocorrer nas séries mais próximas aos anos iniciais do Ensino Fundamental.

Após esse mapeamento, as formas em questão foram organizadas em um quadro, o qual descreveu os dados a partir dos seguintes critérios: qual a ocorrência mapeada, a localização no corpus, ou seja, se o texto no qual se encontra a ocorrência é do $6^{\circ}, 7^{\circ}, 8^{\circ}$ ou $9^{\circ}$ ano e qual sua tipologia/gênero, e a ocorrência contextualizada em um trecho da redação, conforme é exposto a seguir em uma amostra de tal quadro: 
Quadro 1. Amostra de como as ocorrências foram mapeadas

\begin{tabular}{|c|l|l|}
\hline $\begin{array}{c}\text { Ocorrência } \\
\text { (palavra hiperseg- } \\
\text { mentada) }\end{array}$ & \multicolumn{1}{|c|}{ Série/Gênero } & \multicolumn{1}{c|}{ Contexto } \\
\hline completamente & $\begin{array}{l}6^{\circ} \text { ano/ Relato de experi- } \\
\text { ência }\end{array}$ & $\begin{array}{l}\text { E o meu sexto desejo é que meu futuro } \\
\text { seja com pleto de felicidades, alegria, } \\
\text { paz, e com pletamente de carinho e } \\
\text { amor pela minha familia! }\end{array}$ \\
\hline vagarosamente & $\begin{array}{l}70 \text { ano/ Relato de expe- } \\
\text { riência }\end{array}$ & $\begin{array}{l}\text { O asacino apareceu com uma cera ele- } \\
\text { triga atras de mim eu coria maes que eu } \\
\text { potia eu me esgonti no banheiro estava } \\
\text { muinto selencioso la fora eu vacarosa } \\
\text { mente estava saino e as portas estava } \\
\text { tramcada }\end{array}$ \\
\hline vacarosa mente) & Z09_6D_19M_02 & \\
\hline
\end{tabular}

Fonte: elaboração própria.

A partir da organização das ocorrências mapeadas, foi possível descrever e analisar, sobretudo ao observarmos o contexto no qual tais advérbios estavam inseridos, se o fenômeno da hipersegmentação teve motivação de ordem prosódica, rítmica, morfossintática entre outras.

\section{Resultados}

O objetivo principal desta seção é trazer os resultados, as descrições e análises das ocorrências de advérbios em -mente que apareceram hipersegmentadas no corpus composto por 5.519 redações escolares do Ensino Fundamental II.

Apesar de ter sido realizada a quantificação dos dados mapeados, o foco da análise é qualitativo. Sendo assim, primeiramente são expostos quadros, tabelas e gráficos com o intuito de descrever a estrutura da ocorrência segmentada (se o ponto de corte da hipersegmentação coincide ou não com a palavra fonológica) a fim de, posteriormente, apresentar a motivação (fonológica, morfossintática, ortográfica, entre outras) para ocorrer determinada estrutura hipersegmentada. Em outras palavras, a quantificação dos dados é 
exposta com o objetivo maior de, a partir dela, realizar a análise qualitativa tomando como base as teorias já apresentadas na seção 1 .

Comecemos expondoum quadro com as ocorrências dehipersegmentação dos advérbios em - mente nas redações escolares do Ensino Fundamental II:

Quadro 2. Formas hipersegmentadas dos advérbios em -mente em redações escolares

\begin{tabular}{|c|c|c|}
\hline $\begin{array}{c}\text { Ocorrência } \\
\text { (palavra hiperseg- } \\
\text { mentada) }\end{array}$ & Série/Gênero & Contexto \\
\hline completamente & 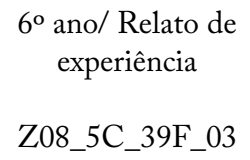 & $\begin{array}{l}\text { E o meu sexto desejo é que meu futuro seja com } \\
\text { pleto de felicidades, alegria, paz, e com pleta- } \\
\text { mente de carinho e amor pela minha familia! }\end{array}$ \\
\hline $\begin{array}{l}\text { vagarosamente } \\
\text { (vacarosa mente) }\end{array}$ & $\begin{array}{l}\text { 7o ano/ Relato de } \\
\text { experiência } \\
\text { Z09_6D_19M_02 }\end{array}$ & $\begin{array}{l}\text { O asacino apareceu com uma cera eletriga } \\
\text { atras de mim eu coria maes que eu potia eu me } \\
\text { esgonti no banheiro estava muinto selencioso la } \\
\text { fora eu vacarosa mente estava saino e as portas } \\
\text { estava tramcada }\end{array}$ \\
\hline completamente & $\begin{array}{l}\text { 80 ano/Relato de } \\
\text { mudança de vida } \\
\text { Z10_7D_01F_02 }\end{array}$ & $\begin{array}{l}\text { Bom, desde o dia que eu fiz o teste para } \\
\text { garota propaganda, e fui escolhida mi- } \\
\text { nha vida mudou complet(a)mente, mui } \\
\text { dou muito. }\end{array}$ \\
\hline realmente & $\begin{array}{l}8^{\circ} \text { ano/Relato de } \\
\text { mudança de vida } \\
\text { Z10_7D_01F_02 }\end{array}$ & $\begin{array}{l}\text { Conheceria gente que começou antes } \\
\text { de mim, na ciareira artistica, } \\
\text { e de que eu era fã. E isso seria } \\
\text { real mente muito bom, com certeza } \\
\text { pra mim e para os outros. }\end{array}$ \\
\hline absolutamente & $\begin{array}{l}\begin{array}{l}8^{\circ} \text { ano/Relato de } \\
\text { experiência }\end{array} \\
\text { Z10_7A_31M_04 }\end{array}$ & $\begin{array}{c}{[\ldots] \text { alguns da nós Iamos em shows da banda em }} \\
\text { São Paulo é era absoluta mente incriveis, Mais } \\
\text { depois de alguns anos veio a pior notícia o RBD } \\
\text { vai se separa no começo de } 2009 \text {. }\end{array}$ \\
\hline simplesmente & 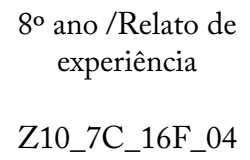 & $\begin{array}{l}\text { A moda é simplis mente perfeita e eles são } \\
\text { lindos "o que mais uma garota pode querer?" }\end{array}$ \\
\hline
\end{tabular}




\begin{tabular}{|c|c|c|}
\hline simplesmente & 9o ano/Enquete & eu não tinho o um istilo formado \\
sabe simples mente gosto de me vistir bem com \\
uma coisa
\end{tabular}

Fonte: elaboração própria.

Ao observar o quadro 2, é possível perceber que em grande parte das ocorrências mapeadas o fenômeno da hipersegmentação ocorreu a partir da estrutura base adjetiva segmentada do "sufixo" - mente. Em Abreu-Zorzi (2016), tal estrutura não nos será inusitada, uma vez que os advérbios em -mente seriam formas que apresentariam dois acentos independentes - um de palavra, geralmente presente no elemento - mente - e um secundário, atribuído por questões prosódicas e rítmicas, presente na base desses advérbios. Logo, o que nos foi revelado pela maioria das ocorrências hipersegmentadas dos advérbios em -mente nos mostra que esse fato de tais formas adverbiais serem segmentadas em base + "sufixo" está relacionado à atribuição do acento nesses advérbios e à coincidência ou não do ponto de corte com a palavra fonológica. Para descrevermos melhor essa questão, apresentamos a tabela e o gráfico a seguir: 
Tabela 1 - Estrutura da hipersegmentação dos advérbios em -mente

\begin{tabular}{|c|c|}
\hline Ponto de corte da hipersegmentação dos advérbios em -mente & Subtotal \\
\hline Coincidindo com a palavra fonológica $(\oplus)$ & $7(65 \%)$ \\
\hline Não coincidindo com a palavra fonológica $(\oplus)$ & $4(35 \%)$ \\
\hline TOTAL & $11(100 \%)$ \\
\hline
\end{tabular}

Fonte: elaboração própria.

No total de 11 ocorrências de advérbios em -mente hipersegmentados no corpus das redações escolares, 7 (65\%) apresentam o seu ponto de corte coincidindo com a palavra fonológica e apenas 4 (35\%) não coincidem com $₫$. Para melhor visualização, há o Gráfico 1:

Gráfico 1- Distribuição dos advérbios em -mente hipersegmentados considerando o ponto de corte

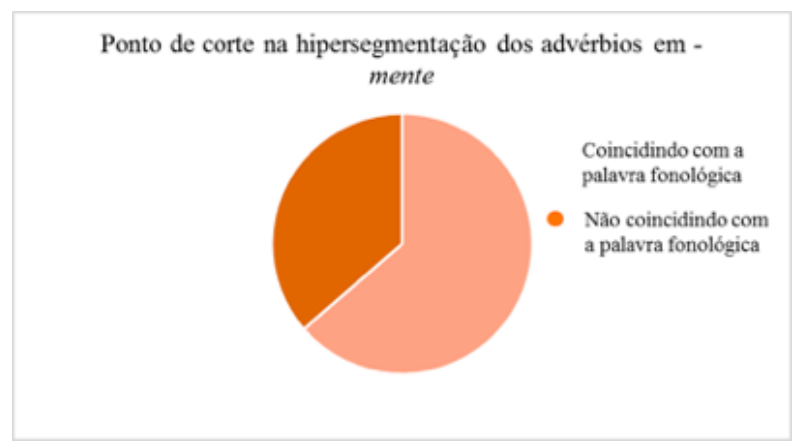

Fonte: elaboração própria.

Sobre o fato de o ponto de corte coincidir com a palavra fonológica é possível inferir que, no momento de hipersegmentar tais advérbios, os alunos considerariam em primeiro lugar a noção de palavra. Segundo Cunha e Miranda (2009), mesmo antes de entrar para a escola, o aprendiz

[...] graças às práticas de letramento às quais está exposto cotidianamente, já construiu suas hipóteses no que diz respeito à segmentação da escrita. No entanto, ao testá-las, o que se lhe apresenta é a dúvida sobre o lugar em que esses espaços devem ser inseridos. Para a resolução desse novo problema é necessário que o aprendiz dê conta da complexa tarefa de compreender o que é uma palavra. (Cunha; Miranda, 2009, p. 127) 
Sendo assim, o conceito de palavra mais comumente utilizado pelos alunos para realizar a hipersegmentação das formas adverbiais em -mente parece ser o de palavra gramatical, visto que, como grande parte desses advérbios são formados pela estrutura base adjetiva feminina +- mente o aluno tende a separar a base, que é uma palavra gramatical "pronta" (por exemplo, absoluta) do restante do enunciado.

Utilizando os critérios de segmentações não-convencionais do português propostos por Cunha e Miranda (2009), conseguimos observar que as hipersegmentações nas quais o ponto de corte coincide com a palavra fonológica podem apresentar a seguinte estrutura:

(1) vacarosa mente

(2) real mente

(3) absoluta mente

(4) simplis mente

(5) simple mente

(6) razoavel mente

(7) futural mente
Base adjetiva +- mente

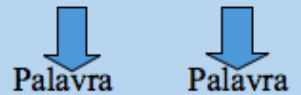

Gramatical Fonológica

( $\quad$ ( ) $)$

men te

Nessas ocorrências, constatou-se que -mente é uma palavra fonológica, pois ao formar um pé métrico (troqueu moraico) apresentam uma proeminência (que seria o acento de palavra). Além disso, tomando como base Corrêa $(2001,2004)$, supõe-se que a hipersegmentação dessas ocorrências de advérbios em -mente poderiam ser explicadas pelo "já escrito", pois quando o aluno segmenta tais formas desvinculando o "sufixo" da sua base, subentendese que ele considerou "mente" uma palavra morfológica/lexical como em "Aquele homem tem uma ótima mente" OU "Ele não sai da minha mente". Logo, há dois motivos que justificam a hipersegmentação da maior parte dos advérbios: -mente é uma palavra fonológica, com acento independente, e tem coincidência com uma palavra lexical/morfológica.

Retomando a tabela e o gráfico 1 , podemos observar que há 4 ocorrências nas quais o ponto de corte não coincide com a palavra fonológica. A seguir, 
descrevemos e analisamos cada uma delas individualmente, visto que cada caso apresenta um dado singular.

$1^{\mathrm{a}}$ ocorrência: a tuamente

Para descrevermos tal ocorrência, apresentamos duas possibilidades de análise para o caso:

a) a hipersegmentação motivada por um acento de foco prosódico;

b) a hipersegmentação motivada por questões de escrita do próprio texto.

Para o primeiro caso, nos embasamos no estudo de Abreu-Zorzi (2016), retomado em Abreu-Zorzi e Massini-Cagliari (2018), o qual trabalha com o estatuto prosódico dos advérbios em -mente. Segundo a autora, quando os advérbios em -mente apresentam a estrutura base adjetiva + -mente, eles tendem a manter o acento da base se esta for paroxítona. Como exemplo disso, ela mostra ocorrências mapeadas como "abértamente" e "devótamente". Porém, se a base for oxítona, há uma tendência ao deslocamento do acento da base, visto que há um choque acentual (Hayes, 1995; Massini-Cagliari, 1995) entre o acento da base e o acento do elemento -mente, como mostra o exemplo a seguir, embasado em Abreu-Zorzi (2016, p.174):

(3) cruél + ménte crùelménte

O exemplo anterior nos mostra que quando há o choque acentual, o acento da base é deslocado para uma sílaba à esquerda da palavra, tornando-se um acento secundário. Embasando-nos em alguns estudos (Massini-Cagliari; Cagliari, 2001; Costa, 2010), o acento secundário é uma proeminência prosódica que pode ocorrer ou por efeito das regras de eurritmia da língua ou por fatores lexicais. No primeiro caso, o acento secundário ocorre, pois

Como, em português, uma seqüência muito longa de sílabas átonas não é aceitável, algumas dessas sílabas passam a ter um reforço extra, formando uma onda rítmica mais regular. Dessa forma, a ocorrência de acentos 
secundários pode ser considerada um efeito de regras de eurritmia da língua. (Massini-Cagliari; Cagliari, 2001, p.114)

Por outro lado, o acento secundário motivado por fatores lexicais ocorre quando, no momento de formação de uma palavra, tem-se a necessidade de marcar um reforço extra. No exemplo (8), o acento secundário da ocorrência "cruelmente" é motivado por fatores lexicais - visto que, no momento de adjunção de -mente à base cruel ocorreu um choque dos acentos - também é motivado por questões de eurritmia da língua, uma vez que, no sistema linguístico do português não é aceitável uma sequência de duas sílabas tônicas, o que gera um acento secundário em um intervalo a cada duas sílabas.

Fato semelhante ocorre com a palavra "a tuamente", mapeada no corpus das redações escolares. A base "atual" é oxítona e ao ser adjungida ao elemento -mente (que apresenta acento na sílaba -men) sofre um choque acentual, culminando no deslocamento do acento da sílaba al para a sílaba a, conforme mostra o exemplo a seguir, representado pelas grades métricas parentetizadas (HAYES, 1995):

(4)

a.

\begin{tabular}{|c|c|c|c|}
\hline & $\mathrm{x}$ & ) \\
\hline & $x$ ) & $(\mathrm{x}$ & .) \\
\hline$\left(\begin{array}{ll}x & .\end{array}\right)$ & $(\mathrm{x})$ & $(\mathrm{x}$ & .) \\
\hline
\end{tabular}

b.

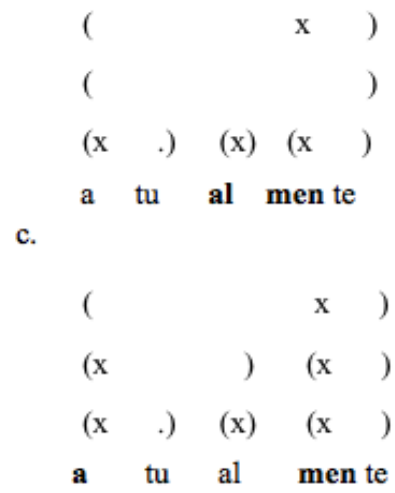


As grades anteriores mostram as etapas de aplicação da "Regra do Mova X”, de Hayes (1995), utilizada quando há um choque acentual no momento de formação de uma determinada estrutura na língua. Na etapa b, linha 1 , constata-se o choque acentual entre a última silaba da base e a silaba "men" de -mente. A fim de resolver o choque entre acentos, verifica-se na etapa c, linha 1, o deslocamento do acento da base para uma sílaba mais à esquerda da palavra.

Considerando os estudos de Massini-Cagliari; Cagliari (2001) e Costa (2010) sobre os acentos secundários, constatamos que em a tuamente há a presença de um acento secundário em "a", motivado lexicalmente, pois tal acento só ocorreu a partir do momento no qual o elemento -mente foi adjungido à base "atual". Além disso, há ainda uma motivação por fatores de eurritmia da língua, uma vez que uma sequência de várias silabas tônicas não é aceitável em português.

Embasando-nos nas reflexões de Fernandes (2007) a respeito de acento neutro e acento marcado em português, a presença de um acento secundário na sílaba "a" indica um acento marcado, ou seja, que não segue a NSR e, portanto, é um acento de foco prosódico.

Como já apresentado na seção de embasamento teórico, há certos contextos nos quais o falante/escrevente necessita dar uma ênfase para um constituinte que não é assinalado com acento principal. Sendo assim, o autor de um texto passa a utilizar a gramática do discurso, recorrendo ou à desacentuação do acento principal ou à marcação de um acento adicional no constituinte que precisa ser focalizado.

Logo, no caso de a tuamente, uma das possibilidades para a realização da hipersegmentação é a de que o aluno necessitou, naquele momento do seu texto, dar uma ênfase a um elemento que não trazia um acento principal, mas sim um secundário.

Uma segunda possibilidade para a realização da hipersegmentação nesse caso leva em consideração questões de escrita do próprio texto. Em outras palavras, é possível ainda que o aluno, devido a uma memória ortográfica, tenha considerado o "a" uma preposição ou um artigo ou até mesmo tenha pensado em uma estrutura sintática como "A tua mente" (mente = pensamento) 


\section{2a ocorrência: com pletamente}

Ao observarmos a ocorrência com pletamente, verificamos que as possibilidades de realização da hipersegmentação propostas por Cunha e Miranda (2009) não conseguiriam descrever tal ocorrência, visto que, apesar de "com" ser uma palavra gramatical, "pletamente" não forma palavra gramatical nem fonológica. Sendo assim, o que parece ter motivado a hipersegmentação nesse caso está relacionado à questões discursivas e não prosódicas.

Em um primeiro momento, observando tal forma hipersegmentada, há uma tendência em afirmar que a motivação para a hipersegmentação desse caso seria prosódica por “com" ser um clítico. No entanto, é preciso destacar que esse caso não se encaixaria nos clíticos, uma vez que, segundo Nespor e Vogel (1986), a categoria do grupo clítico é composta por um ou mais clíticos acompanhado(s) por um único item de conteúdo. Por sua vez, os clíticos podem pertencer a diferentes classes gramaticais (preposição, conjunção, artigo, etc.) e, dos pontos de vistas sintático e fonológico, são formas dependentes (Câmara, 1970), em razão de não poderem ocorrer sozinhos em um enunciado. Além disso, para a fonologia, pelo fato de serem formações átonas (não-acentuadas), os clíticos apoiam-se no acento da palavra precedente ou seguinte (Bisol,2005). Logo, como neste caso o "com" não é dependente do restante da palavra, tal partícula não faria parte de um grupo clítico e, consequentemente, a motivação para a hipersegmentação não foi de ordem prosódica.

Como já exposto na seção de embasamento teórico e discutido na análise da ocorrência a tualmente, em alguns contextos o falante/escrevente necessita dar uma ênfase, um destaque para um termo que não apresenta um acento principal e é isso que podemos observar em com pletamente. Considerando essa reflexão, iniciamos a descrição de tal forma hipersegmentada apresentando-a contextualizada no corpus analisado:

(5) "E o meu sexto desejo é que meu futuro seja com pleto de felicidades, alegria, paz, e com pletamente de carinho e amor pela minha familia!" (6 ano/ Relato de experiência, Z08_5C_39F_03) 
Além da hipersegmentação de completamente, o exemplo (10) revela ainda a forma hipersegmentada de com pleto. Se tomarmos como base esse trecho, percebemos que o autor do texto optou por atribuir uma ênfase ao elemento "com", tanto em completo quanto em completamente, objetivando destacar que seu maior desejo é que seu futuro seja um período com felicidades, com alegria, com paz, com carinho e com amor. Em outras palavras, o escrevente/autor dessa redação hipersegmentou a ocorrência completamente partindo do elemento "com", pois, provavelmente, por analogia à forma com pleto ele interpretou "com", no contexto em que se encontra, como uma palavra gramatical da língua.

\section{3a ocorrência: com plet(a)mente}

Diferentemente das duas ocorrências anteriores, as quais apresentam como motivações para a hipersegmentação questões de natureza prosódica e discursiva, com plet (a) mente é a única forma adverbial hipersegmentada mapeada nas redações escolares que traz como motivação para a hipersegmentação a questão ortográfica, mais especificamente a rasura.

Pode-se afirmar que essa ocorrência configura-se como um dos dados mais singulares mapeados. Para tentar solucionar essas questões, consideramos alguns trabalhos sobre rasura, sobretudo os de Fabre (1987) e Calil e Felipeto (2000). Como já exposto na seção de embasamento teórico, Fabre (1987) afirma que o processo de rasura em um texto está relacionado a atividades metalinguísticas e metadiscursivas daquele que escreve. Segundo esse autor ainda, há quatro operações “metalinguísticas» no processo da rasura: supressão, substituição, deslocamento e adição.

No caso da nossa ocorrência em específico (com plet(a)mente), podemos inferir que a operação metalinguística que ocorre é a de supressão, uma vez que o termo escolhido é riscado, rasurado e não substituído. Portanto, ao rasurar, o aluno mostra certa insegurança em relação à ortografia de tal vocábulo. Percebe-se essa insegurança, sobretudo, se analisarmos atentamente a versão digitalizada da redação na qual a ocorrência em questão se encontra, visto que 
nela é possível constatar já no título do texto o processo de hipersegmentação da mesma palavra, conforme aponta a figura a seguir:

Figura 5. Hipersegmentação da palavra completamente

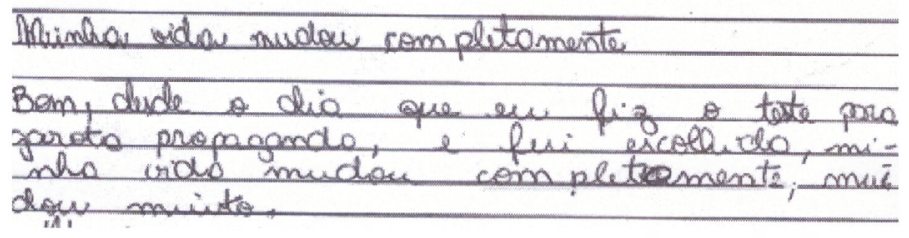

Fonte: Banco de Dados de Escrita do Ensino Fundamental II

Sendo assim, o fato de o aluno realizar duas formas distintas de hipersegmentação nos mostra, de acordo com Calil e Felipeto (2000), muito mais que uma operação metalinguística; mostra uma preocupação do escrevente/ autor com os discursos correntes em sala de aula, já que

[...] o ensino da escrita neste momento escolar está fortemente assentado sobre discursos que constróem um imaginário de texto em torno das convenções espaciais, gráficas, ortográficas e textuais, como por exemplo, a necessidade de deixar espaço para paragrafação, a marcação de letras maiúsculas, o lugar do título e das margens, o tipo ou o desenho da letra, a letra ortograficamente correta, etc. (Calil; Felipeto, 2000, p. 104)

Nesse sentido, a rasura

não seria muito mais o efeito ou uma identificação aos discursos correntes em sala de aula e que constituiriam este momento do ensino da língua portuguesa, sobre o aluno e da forma como o texto é aí significado, do que uma operação metalinguística. (Calil; Felipeto, 2000, p.104)

Logo, embasando-se em Calil e Felipeto (2000), quando o aluno hipersegmenta a mesma palavra de formas distintas, ele busca a semelhança para o reconhecimento entre o que se diz/escreve e o que se «deve» dizer/escrever. Tal reconhecimento está mais relacionado à submissão ao funcionamento linguísticodiscursivo do que com um «controle» em uma operação metalínguística. 
Para descrever e analisar essa ocorrência, embasamo-nos em estudos que tratam da relação entre foco semântico e proeminência principal, visto que acreditamos que a hipersegmentação dessa forma adverbial teria sido motivada por um desalinhamento entre a proeminência principal e o foco semântico. Um desses estudos é o de Nespor e Guasti (2002). Segundo as autoras, há casos nos quais o acento é percebido como marcado, ou seja, de foco prosódico, assinalado por regras diferentes da NSR (no caso do português, o acento atribuído mais à direita). Isso é o que acontece com a ocorrência em questão.

Em prova velmente, o acento neutro, assinalado pela NSR, recai em -mente, proeminência principal da palavra. No entanto, ao hipersegmentar essa forma e atribuir o ponto de corte em "prova", observa-se que este elemento focalizado não ocupa a posição receptora da proeminência fonológica principal, que no caso seria em -mente. Um dos motivos pelos quais isso ocorre está relacionado ao contexto em que tal forma adverbial se encontra. Sendo assim, a possível "explicação" para a hipersegmentação dessa ocorrência não diz respeito mais à gramática da sentença, mas sim à uma gramática do discurso. Para exemplificarmos melhor essa questão, apresentamos a seguir o trecho no qual se encontra a forma prova velmente:

(6) "Prova velmente as crianças coseguiram superar isso, com muita conversa, terapia e distrações. A tragedia aconteceu um uma escola municipal, chamada Tasso da Silveira, localizado no bairro de Realendo". (9ªno/ Carta de Opinião, Z11_8B_04F_03)

Observando o trecho no qual se encontra a ocorrência, é possível perceber que se a hipersegmentação de tal palavra ocorresse levando em consideração a gramática da sentença, teríamos o ponto de corte coincidindo com as palavras gramatical e fonológica, ou seja, uma estrutura como: provável mente. No entanto, nesse contexto, constata-se que "prova" precisou ser focalizado. Uma explicação para tal fato pode estar relacionada ao gênero textual e à proposta de redação que serviram de base para a produção do texto no qual ocorre a forma hipersegmentada em questão. Vejamos a proposta de redação para podermos compreender melhor a situação: 
Figura 6. Proposta de redação número 3 (Carta de Opinião)

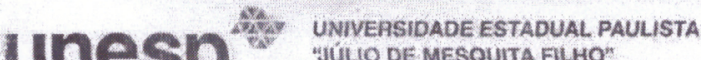 \\ "JULLO DE MESQUITA FILHO" \\ Campus de Sáo Jase do Rio Preto}

Projeto de extensăo: Oficinas de Leitura, Interpretaçâo e Produçăo Textual - Coordenação Luciani Tenani

\section{E.E. Professora Zuimira da Silva Salles}

Nome:

Proposta 3

Série/Turma: $8^{\circ} D \quad$ No 36

Data: $18 / 05 / 2011$

- Você percebeu que em sua carta Francisco pede mais informaçőes sobre o ocorrido em Realengo e faz uma série de perguntas. Produza uma carta em resposta ao texto escrito por Francisco González.

Para atender às expectativas de Francisco, é preciso expor algumas informaçōes sobre a tragédia a que ele se refere $\epsilon$ apresenter o que vocè acha sobre esse tema, levando em consideração as perguntas que ele faz. Tente, ao responder as perguntas, justificar a sua opinião apresentando alguns argumentos.

- Seu texto deve conter de 25 a 30 linhas e deve ser escrito á tinta. Seu texto náo deve ultrapassar os limites designados para a escritura.

Fonte: Banco de Dados de Escrita do Ensino Fundamental II

Ao observarmos a proposta de redação, supõe-se que "prova" precisa ser focalizado, pois, devido ao gênero textual no qual tal ocorrência se encontra (Carta de opinião), percebe-se que o aluno responde, de forma indireta a um interlocutor (no caso, Francisco), conforme aponta a proposta de escrita para esse texto.

Considerando ainda o estudo de Nespor e Guasti (2002), o fato de "prova" precisar ser focalizado faz com que o escrevente/autor utilize uma alternativa para alinhar foco semântico e proeminência fonológica. Logo, há uma mudança da proeminência principal do elemento mais à direita (-mente, no caso) para o elemento focalizado (prova), conforme mostra o exemplo (7) a seguir:

(7) provável + -ménte $=$ próva velmente

\section{Conclusão}

Ao término deste artigo, é possível inferir que grande parte das ocorrências de advérbios em -mente foram hipersegmentadas no corpus das redações escolares do Ensino Fundamental II motivadas por questões de natureza prosódica, nas quais se observa que o ponto de corte da hipersegmentação coincide com a palavra fonológica. 
No entanto, mapeamos algumas ocorrências singulares, uma vez que cada uma delas apresentou uma motivação específica para a realização da hipersegmentação. Em tais ocorrências, pudemos observar motivações de viés ortográfico, mais especificamente relacionada às rasuras (no caso de com plet(a) mente), e de viés discursivo (no caso de com pletamente e prova velmente).

Por fim, o mapeamento e a análise do processo de hipersegmentação no português contribuiu para a descrição mais geral dos componentes fonológico, morfológico e sintático na atual sincronia desta língua. Ademais, com a descrição e análise dos dados, evidenciou-se que a hipersegmentação do advérbio focalizado movimenta mais que aspectos dicotômicos, como certo ou errado de acordo com o viés de "erro" ortográfico de uma gramática normativa, é um processo extremamente complexo que envolve domínios prosódicos, morfológicos e sintáticos.

\section{Agradecimentos}

CNPq e CAPES.

\section{REFERÊNCIAS}

ABAURRE, M. A relevância dos critérios prosódicos e semânticos na elaboração de hipóteses sobre segmentação na escrita inicial. In: Boletim da Abralin, Campinas, v. 11, p. 203-217, 1991.

. O que revelam os textos espontâneos sobre a representação que faz a criança do objeto escrito? In: KATO, M.A. (org). A concep̧̧ão da escrita pela criança. Campinas: Pontes, 2002, p. 135-142.

ABAURRE, M.; SILVA, A. O desenvolvimento de critérios de segmentação na escrita. Temas psicol. [online]. 1993, vol.1, n.1, p. 89-102. ISSN 1413-389X.

ABREU-ZORZI, T. H. O estatuto prosódico de advérbios em -mente: um estudo comparativo entre português arcaico e português brasileiro. 2016. 228f. Tese 
(Doutorado em Linguística e Língua Portuguesa) - Faculdade de Ciências e Letras, Universidade Estadual Paulista, Araraquara, 2016.

ABREU-ZORZI, T. H.; MASSINI-CAGLIARI, G. A atribuição do acento nos advérbios em -mente no português: discussão de aspectos prosódicos e rítmicos. In: ALFA: Revista de Linguística. São Paulo: Universidade Estadual Paulista, v.62, n.2, 2018, p.381-408.

BISOL, L. Constituintes prosódicos. In: BISOL, L. (Org.). Introdução a estudos de fonologia do português brasileiro. Porto Alegre: EDIPUCRS, 1996, p. 247-261.

CALIL, E.; FELIPETO, S.C. Rasuras e operações metalinguísticas: problematizações e avanços teóricos. In: Caderno Estudos Linguísticos. Campinas, 39, p.95-110.

CAPRISTANO, C. C.; MACHADO, T. H. S. Uma análise quantitativa de rasuras ligadas à segmentação em enunciados produzidos no Ensino Fundamental I. In: Revista LinguíStica (Revista do Programa de Pós-Graduação em Linguistica da Universidade Federal do Rio de Janeiro). Volume 11, número 1, junho de 2015, p. 216-229.

CHACON, L. Relações metafóricas e metonímicas: notas sobre a "aquisição" da noção de palavra. In: Tfouni, L. V.; Toneto, D. J. (Org.). O (In)esperado de Jakobson. Campinas: Mercado de Letras, 2014.

CHOMSKY, N. Deep structure, surface structure and semantic interpretation. In: STEINBERG, D. ; L. JAKOBOVITS (Ed.). Semantics: an interdisciplinary reader in philosophy, linguistics and psychology. Cambridge, UK: Cambridge University Press, 1971.

CHOMSKY, N.; HALLE, M. The Sound Pattern of English. New York: Harper \& Row, 1968.

CINQUE, G. A null theory of phrase and compound stress. In: Linguistic Inquiry, n. 24, 1993, p.239-297. 
CORRÊA, M. L. G. Letramento e heterogeneidade da escrita no ensino de português. In: SIGNORINI, I. (Org.) Investigando a relação oral/escrito e as teorias do letramento. Campinas: Mercado das Letras, 2001, p. 135-166. . O modo heterogêneo de constituição da escrita. São Paulo: Martins Fontes. 2004.

COSTA, D.S. da. A interface música e linguística como instrumental metodológico para o estudo da prosódia do Português Arcaico. 2010. 200 f. Tese (Doutorado em Linguística) - Faculdade de Ciências e Letras, Universidade Estadual Paulista, Araraquara, 2010.

CUNHA, A.P.N; MIRANDA, A.R.M. A hipo e a hipersegmentação nos dados de aquisição de escrita: a influência da prosódia. In: Revista Alfa, São Paulo, no53, v.1, 2009, p.127-148.

FABRE, C. La reecriture dans l'ecriture: Le cas des ajouts dans lês écrits scolaires. In: Études de Linguistiques Appliqueé, Paris, 68, 1987.

FERNANDES, F.R. Ordem, focalização e preenchimento em português: sintaxe e prosódia. 2007. 391f. Tese (Doutorado em Linguística) - Universidade Estadual de Campinas, Instituto de Estudos da Linguagem. 2007.

HAYES, B. Metrical Stress Theory: Principles and Case Studies. Chicago, London: University of Chicago Press, 1995.

JACKENDOFF, R. Semantic interpretation in generative grammar. Cambridge: MIT Press, 1972.

MASSINI-CAGLIARI, G. Cantigas de amigo: do ritmo poético ao linguístico. Um estudo do percurso histórico da acentuação em Português. 1995. 300 f. Tese (Doutorado em Linguística) - Instituto de Estudos da Linguagem, Universidade de Campinas, Campinas, 1995. 
MASSINI-CAGLIARI, G.; CAGLIARI, L.C. Fonética. In: MUSSALIM, F.; BENTES, A. C. (Org.). Introdução à Linguística: domínios e fronteiras. São Paulo: Cortez, 2001.v. 1, p. 105-146.

NESPOR, M.; VOGEL, I. Prosodic Phonology. Dordrecht: Foris Publications, 1986.

NESPOR, M.; GUASTI, M. T. Focus to stress alignment and its Consequences for Acquisition. In: Lingue e Linguaggio, n. 1,2002, p.79-196.

SELKIRK, E. O. On prosodic structure and its relation to syntactic structure. Bloomington, Indiana University Linguistics Club. 1980.

TENANI, L. E. Banco de Dados de Escrita do Ensino Fundamental II. Disponível em: http://www.convenios.grupogbd.com/redacoes/Login. Acesso em 20 mar. 2020.

. Prosódia e escrita: uma análise a partir de (biper)segmentações de palavra. 2016. 211f. Tese (Livre docência em Fonologia) - Instituto de Biociências, Letras e Ciências Exatas (IBILCE), Universidade Estadual Paulista, São José do Rio Preto, 2016.

TENANI. L.E.; LONGHIN-THOMAZI, S.R. Oficinas de leitura, interpretação e produção textual no Ensino Fundamental. In: Em extensão, Uberlândia, no. 1, v.13, 2014, p.20-34.

VIGÁRIO, M. The prosodic word in European Portuguese. 2001. 440 f. Dissertation (PhD of Linguistics) - Faculdade de Letras da Universidade de Lisboa, Universidade de Lisboa, Lisboa, 2001. 


\section{A NATUREZA CONSERVADORA DO ACENTO NAS PA- LAVRAS PAROXÍTONAS TEMINADAS EM CONSOANTE}

Luann Dias de Souza

José Magalhães

\section{Introdução}

O propósito maior deste capítulo é revisitar o acento nominal do português numa perspectiva diacrônica, colocando em relevo as palavras paroxítonas terminadas em consoante. A atenção sobre esses vocábulos se justifica por serem considerados irregulares, ou marcados, quanto à acentuação, uma vez que, embora possuam sílaba final terminada em consoante, recebem acento penúltimo. Esse fato contrariaria o argumento de que o português seja sensível ao peso quando a sílaba final é dotada de rima ramificada (Bisol, 1992, 1994; Magalhães, 2008)

As palavras paroxítonas são as de maior número no português e, neste conjunto, aquelas que terminam em vogal e que possuem acento penúltimo são consideradas as mais comuns, o que aponta para uma regra de acento padrão, como a apresentada a seguir:

$$
\mathrm{V}>[+\mathrm{ac}] / \ldots(\mathrm{C}) \mathrm{V \#}
$$

Palavras como casa, pessoa, anjo, cadeira, nome ilustram a regra.

Se as palavras paroxítonas terminadas em vogal representam um padrão mais geral na língua, é preciso destacar que, embora em menor quantidade, há palavras de uso frequente que, apesar de portadoras de acento penúltimo, terminam em consoante. Exemplificam este fato, vocábulos como jovem, nível, hífen e cadáver.

Há análises do acento do português que veem nessas palavras alguma excepcionalidade pelo fato de irem em direção contrária a dois padrões acen- 
tuais defendidos na literatura (Bisol, 1992, 1994; Magalhães 2008; Wetzels 1992, Massini-Cagliari, 1999), quais sejam:

i) Palavras terminadas em vogal recebem acento na penúltima sílaba (casaco, palavra, parte...)

ii) Palavras terminadas em consoante recebem acento final (calor, funil, cartaz...)

Em favor desses dois padrões, Bisol $(1992,1994)$ propõe duas regras de acento baseadas na fonologia métrica de Halle e Vergnaud (1987), acenando para a sensibilidade ao peso posicional no português, ou seja, sílabas finais terminadas em consoante atrairiam o acento. Assim se apresentam as regras propostas por Bisol (1992, p. 49; 1994, p.25):

Regra do acento primário

Domínio: a palavra lexical

Regra 1- Atribua um asterisco $\left({ }^{*}\right)$ à sílaba pesada final, ou seja, sílaba de rima ramificada;

Regra 2- Nos demais casos, forme um constituinte binário (não-iterativamente) com proeminência à esquerda, do tipo (* .), junto à borda direita da palavra.
$(* \quad$.
(* .)
$(*)$
(Regra 2)
ca.sa
pare.de
bor.bo.le.ta
$(*)$
$(*)$
(Regra 1)
po.mar
tro.féu
co.ro.nel

Embora em menor número, não se poderia desconsiderar ainda os não verbos proparoxítonos terminados em vogal (árvore, fósforo...), os paroxítonos terminados em consoantes (nível, jovem, cadáver...) e ainda os oxítonos e mo- 
nossílabos tônicos não terminados em consoantes (jïló, café, pá, nó...). A alternativa para representar, nos modelos métricos, as duas primeiras categorias foi recorrer à extrametricidade, um instrumento fornecido pelo modelo de análise que deixa invisível, no processo derivacional, a última sílaba das proparoxítonas e a consoante final das paroxítonas, às quais Bisol chama de formas marcadas. Feito isso, bastaria aplicar a Regra 2 acima.

Acento nas formas marcadas

Proparoxítonas: sílaba final extramétrica $\langle\sigma\rangle$

Paroxítonas: consoante final extramétrica $<c>$
(* .)
$(*)$
(Regra 2)
fos.fo $<$ ro $>$
ar.vo<re>
Ext $<\sigma>$
$(*)$
$(*)$
(Regra 2)
u.ti $<1>$
vi.si.ve $<1>$
Ext $<$ coda $>$

Para as palavras oxítonas e monossílabas tônicas terminadas em vogal, o procedimento seria o inverso da extrametricidade, ou seja, ao invés da invisibilidade de elementos, é proposta a existência de uma consoante subjacente que viria à tona nos processos derivacionais (café > cafezal, cipó > cipozeiro, pé > pedestre). A presença dessa consoante justificaria a aplicação da Regra 1:

(Regra 1)

café(C) cipó(C) pé(C)

Como mencionado no início, este capítulo tem como propósito revisitar o acento paroxítono em palavras terminadas em consoantes, as quais, como anteriormente apresentado, são tratadas como marcadas ou como irregulares para as regras de atribuição de acento. Pretende-se voltar no tempo e fazer um breve percurso diacrônico a fim de descrever como o acento dessas palavras foi se alojar na penúltima sílaba. O caminho a ser trilhado procurará atestar o ca- 
ráter conservador do acento e demonstrar que mudanças na língua, com perda ou acréscimo de material fonético, resultaram no acento referido como irregular. Para a descrição representacional, chamaremos pelo modelo de templates silábicos de Selkirk (1982) e a grade métrica parentetizada de Hayes (1995).

O corpus para a descrição diacrônica advém de um conjunto de palavras selecionadas do dicionário Houaiss, edição de 2015, que conta com aproximadamente 32.000 verbetes. Como o alvo da investigação são as palavras paroxítonas terminadas em consoante, utilizamos como critério de inclusão e exclusão de dados a eliminação de estrangeirismos (designer, modem...); de palavras pouco usuais (ágar, jângal, máuser...) e de composições (lentivírus, biocombustivel...). O interesse central está nas palavras de origem latina; e o caminho da evolução diacrônica para a descrição métrica advém da forma de origem das palavras que fez chegar à forma atual, como em pensĭlis > pênsil, mobülis > móvel, facŭlis > fácil, jovĕnes > jovem.

\section{O Acento Paroxítono}

Grande parte das palavras paroxítonas registras no dicionário consultado advém de processo derivacional formado pelo sufixo -vel, um morfema formador de adjetivo derivativo de verbo: amar > amável; falir > falível. Outra característica deste sufixo é o pré-acento, ou seja, ele é sempre precedido de sílaba acentuada. Esta característica poderia definir uma propriedade morfológica na atribuição do acento em formas derivadas com o sufixo -vel, o que revelaria um acento previsível no português. Porém, como se quer aqui realizar uma análise do ponto de vista diacrônico do acento paroxítono marcado, esse caminho não será perseguido. Importante destacar, conforme apontam Pereira; Silvestre; Villalva (2013, p. 45 - 46), que palavras como afável, horrivel, plausivel, terrivel ou visivel não correspondem a temas verbais. Segundo os autores "decalques das formas latinas e, portanto, o reconhecimento de um sufixo - vel é, nestes casos, ilusório”.

adfari > affabilis 'com quem se pode falar', '(pessoa) agradável' > afável horrere > horribilis 'que pode assustar', 'assustador' > horrível plaudere > plausibilis 'que pode ser aprovado'> plausível 
terrere > terribilis, 'que pode assustar', 'assustador'> terrível

videre > visibilis 'que pode ser visto' > visível

(Pereira; Silvestre; Villalva. 2013, p. 46)

Outra importante revelação dos dados foi o grande número de palavras paroxítonas formadas pelo sufixo -agem, este formador de substantivos: checar $>$ checagem, abordar > abordagem, selva > selvagem, lingua > linguagem. Salientamos ainda que as palavras paroxítonas marcadas costumam ser agrupadas conforme sua terminação consonantal, o que apresentamos a seguir, porém com a subdivisão daquelas terminadas em -m e -1, em virtude do sufixo -agem e do sufixo -vel, respectivamente:

- R: cadáver, mártir

-X: fênix, tórax

-N: abdômen, bifen

-L: (sufixo -vel): amável, louvável

-L: ágil, fértil, têxtil

-M (sufixo -agem): linguagem, selvagem

-M: jovem, álbum

Para o procedimento da análise, dividimos essas palavras em três grupos, a saber: i) palavras terminadas em -vel; ii) palavras terminadas em -agem e iii) demais palavras.

A avalição diacrônica da terminação -vel, como acima referido, um sufixo pré-acento, explicita a alocação do acento na penúltima sílaba, e não na posição final, em atenção à Regra 2 mencionada no início deste texto. Segundo Saraiva (1993), -vel tem origem no sufixo latino -bĭlis, e: "passível de", mais raramente "agente de" algo indicado pelo radical, que de regra é verbal; exemplo, abominabilis, horribilis, spectabilis, immutabilis, commendabilis. Já a transposição de /b/ para /v/ é averiguada em inúmeros casos, como brabus que passa a bravo, caballus que passa a cavalo. Pelo mesmo caminho, -bil passa a -vel.

No Latim Clássico, em palavras com mais de duas sílabas, a primeira sílaba a contar da borda direita da palavra é extramétrica, ou seja, essa sílaba é 
invisível para a aplicação da regra de acento. Para analisarmos o acento dessas palavras, retomamos a regra de acento do Latim Clássico: i) acentue a penúltima sílaba se ela for pesada; ii) do contrário, acentue a sílaba anterior (Allen, 1969).

abominabǐlis>

horrib̆ $<l i s>$

spectab̆ $<$ lis $>$

Nesses exemplos, como a última sílaba -lis é extramétrica e a penúltima sílaba -b̆̌-é leve, o acento só pode se alojar na sílaba anterior, caracterizando todas essas palavras como proparoxítonas.

O sufixo latino -bĭlis chega ao português como -vel. Segundo o dicionário eletrônico Houaiss (2015), em Camões já se observava a forma -bil, sendo, portanto, uma forma intermediária entre o Latim e o português: possíbil, inexpugnábil, imóbil, insensibil, insufríbil, instábil, invencíbil, invisíbil, insufríbil, instábil, invencibil, invisibil, terribil, vendibil, volúbil; mas encontrava também a variação -vel: notável, memoráveis. Dessa forma, temos as formas -bilis > -bil >-vel.

$E$ importante destacar que a estrutura desse sufixo passou por uma mudança importante, qual seja, o apagamento do $i$ e do $s$ finais. Com esse apagamento, a consoante $l$ fica sem sílaba para se fixar. Por isso, ela deixa de ser onset da última sílaba e passa a ser coda da sílaba anterior. Desse modo, a sílaba -lis da forma latina deixa de existir e a sílaba - $b i$, antes leve, passa a -bil, ou seja, uma sílaba pesada. A representação dessa mudança está nas figuras a seguir, segundo modelo silábico de Selkirk (1982):

Figura 1 - Representação silábica “-bülis”

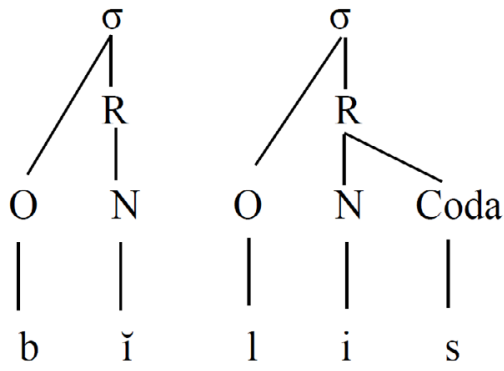


Figura 2 - Queda da rima -is

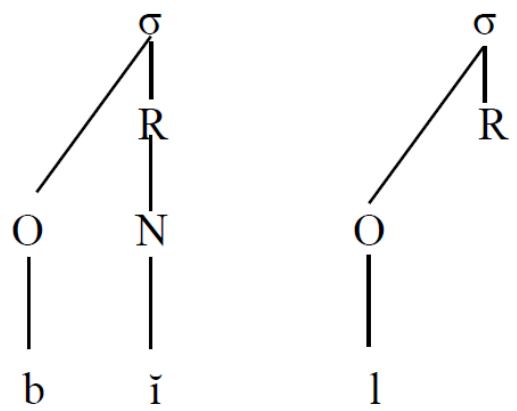

Figura 3 - Associação de -1 à coda

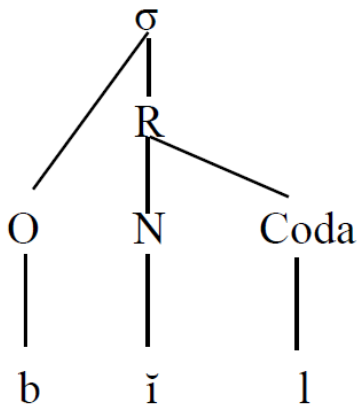

Posteriormente, há outra mudança no sufixo $-b i l$, o $b$ passa a $v$, e o $i$ passa a $e$. Portanto, temos -bil > -vel. A impossibilidade do sufixo -bĭlis de receber acento permanece a mesma, tanto em Camões, com as formas possibil, inexpugnábil, imóbil etc., quanto no português, com as formas insuperável, insubstituivel, irreparável etc. Assim, a regra do acento do Latim, que impede que o sufixo -bĭlis receba acento, continuou atuando, tanto sobre as formas -bil, constatada em Camões, quando em -vel, presentes no português.

Podemos afirmar, portanto, que os radicais latinos que recebiam o sufixo -bĭlis submetiam-se regularmente à na regra do acento latino. No entanto, ao passar para as formas do português arcaico e do português atual, o sufixo latino mantém sua impossibilidade de ser acentuado, produzindo pa- 
lavras marcadas para o sistema de acento no português. Assim, essas palavras paroxítonas terminadas em consoantes refletem claramente o caráter conservador do acento, que se mantém na mesma sílaba de origem, embora hoje sejam tratadas como formas marcadas para a acentuação, numa abordagem sincrônica. $\mathrm{O}$ que houve foi a perda de material segmental e a consequente reestruturação interna da sílaba. $\mathrm{O}$ acento, contudo, permanece na mesma sílaba de origem, embora não mais na mesma posição.

Quanto ao sufixo -agem, este é apresentado por Cunha e Cintra (2001) como sufixo nominal que forma substantivos, indicando "noção coletiva, ato ou estado: folhagem, plumagem, aprendizagem.

Gonçalves (2009) aponta que o sufixo -agem pode ter diferentes origens, dependendo de cada uma das palavras que se vai analisar: i) do sufixo francês formador de substantivo; ii) da terminação latina go/ginis ou iii) do aportuguesamento com outros sentidos. A palavra linhagem, por exemplo, é considerada a mais antiga da língua portuguesa terminada pelo sufixo -agem. O dicionário Houaiss (2015) data essa palavra como sendo do ano de 1188 e que tem como significado "série de gerações; linha de parentesco; genealogia, estirpe".

O dicionário atesta, ainda, a origem da palavra linhagem como sendo do francês antigo lignage, formada a partir de ligne + -age. O Dicionário Etimológico Nova Fronteira da Língua acrescenta que lignage é proveniente do antigo provençal linhatge. $\mathrm{O}$ importante a se observar aqui é o fato de que, sendo linhagem a palavra mais antiga da língua portuguesa terminada pelo sufixo -agem, como consta em Gonçalves (2009), se retomarmos sua origem no francês antigo lignage, ou até mesmo no antigo provençal, perceberemos que não consta da origem dessa palavra a consoante nasal $m$ na posição de coda da sílaba final. A introdução dessa consoante no final da palavra não interfere na posição do acento que mantém, mais uma vez, seu caráter conservador, permanecendo na mesma sílaba:

Antigo Provençal Francês antigo Português

linbatge

lignage

linhagem 
A mudança dessa palavra se deu, portanto, no acréscimo do segmento final $m$ em posição de coda na sílaba final na passagem para o português. Observe a forma no francês antigo:

Figura 4 - Estrutura silábica de "ge" (lignage)

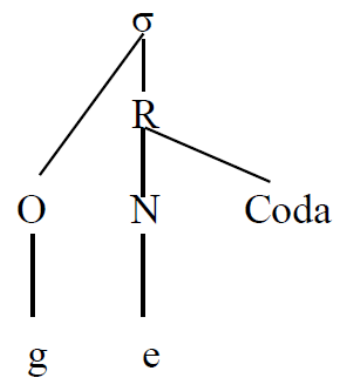

Observa-se, a partir do esquema arbóreo da palavra do francês antigo lignage, que a sílaba final possui núcleo - elemento obrigatório da rima - e tem sua posição de coda não preenchida. Essa posição de coda vazia será preenchida, na passagem para o português, com a consoante nasal $m$, de acordo com a figura a seguir:

Figura 5 - Estrutura silábica de "gem” (lignagem)

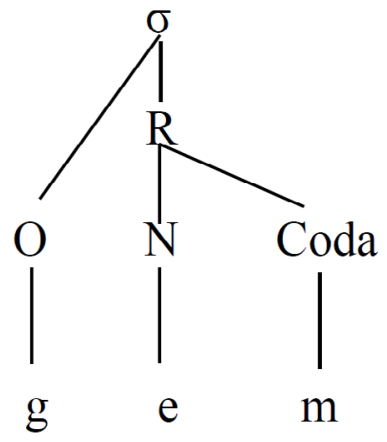

Grande parte das palavras sufixadas por -agem segue a mesma regra da palavra linhagem, ou seja, possui o acento alocado na mesma sílaba da palavra de 
origem, mas adiciona uma consoante nasal que ocupa a posição de coda da sílaba final. Um argumento para essa adição do segmento nasal pode estar na assimilação com diversas outras palavras, como a palavra imagem, que tem origem no latim imāgo. Na evolução de imāgo > imagem, vale o mesmo argumento utilizado em lignage > linhagem, embora tenhamos diferentes origens para cada uma dessas palavras. Em ambos os casos, o acento tônico permaneceu na mesma posição da língua de origem. O que aconteceu nessas palavras foi o acréscimo de material segmental (consoante nasal) na posição de coda da sílaba final.

Essas generalizações podem ser feitas a todas as palavras terminadas em -agem: bagagem < do francês bagage; chantagem < do francês chantage; dublagem < do francês doublage; maquiagem < do francês maquillage; vantagem $<$ do francês avantage, etc.

Acerca das demais palavras paroxítonas terminadas em consoantes que não são formadas com o sufixo -velnem com o sufixo -agem, em praticamente todos os casos o acento tônico permanece na mesma posição que ocupava no latim:

$\begin{array}{ll}\text { Português } & \text { Latim } \\ \text { cadáver } & \text { cadāver } \\ \text { fênix } & \text { phoenix, ìcis } \\ \text { ágil } & \text { agülis } \\ \text { hífen } & \text { byphen } \\ \text { jovem } & \text { jüvenes }\end{array}$

Mesmo nos casos em que existe uma mudança na estrutura da sílaba, o acento permanece na mesma posição da língua de origem, como se pode observar na representação abaixo:

jǔvenes (proparoxítona em Latim) > jovem (paroxítona no português)

Portanto, assim como nos casos anteriores, com os sufixos -vel e -agem, também as paroxítonas com outras terminações revelam o caráter conservador do acento, mesmo que sincronicamente elas atentem contra uma regra padrão que acentua a sílaba final das palavras terminadas em consoantes, conforme a Regra 2. 
Em resumo: i) nas paroxítonas terminadas pelo sufixo -vel houve perda de material segmental da sílaba final e a consequente reestruturação silábica, mas o acento permanece na mesma posição de origem: amabilis > amável; ii) em palavras terminadas em -agem, houve acréscimo de material segmental, mas o acento permanece na mesma posição, tanto nos termos de origem latina como francesa: imāgo > imagem; lignage > linhagem; iii), nos demais grupos de palavras, também o acento permanece na posição de origem, mesmo que palavra sofra alteração em seu material fônico.

\section{Considerações finais}

No empreendimento da análise diacrônica sobre acento penúltimo proposta neste capítulo, procuramos demonstrar que as paroxítonas terminadas em consoante, se observadas desde sua origem, não apresentam irregularidade acentual, pois o acento permanece na mesma sílaba da palavra em sua evolução ao longo do tempo. Seja em palavras derivadas pelo sufixo -vel, formador de adjetivos, seja naquelas que se derivam pelo sufixo -agem ou em outras terminações consonantais, observa-se a natureza conservadora do acento. Importante ainda destacar que os sufixos aqui referidos são altamente produtivos em português (presidenciável, instagramável, tesouragem, crocodilagem...).

Por certo este capítulo não teve nenhuma pretensão de ser exaustivo na averiguação de todas as palavras paroxítonas nem em sua forma de base ou em suas formas derivadas. Contudo, a descrição realizada fornece um ponto de partida para se pensar no acento em português como alinhavado com a morfologia e com a história das palavras. Em todo caso, atesta-se, mais uma vez, a natureza do acento como extremamente conservador na língua.

\section{REFERÊNCIAS}

ALLEN, W. S. The Latin accent: a restatement. Journal of Linguistics, v. 5 (2), p. 193-203, 1969.

BISOL, L. O acento e o pé métrico binário. Cadernos de Estudos Linguísticos, Campinas: UNICAMP, n. 22, p. 69-80., 1992. 
.O acento e o pé métrico binário. Letras de Hoje,v. 98, p.25-36, 1994.

CUNHA, A. G. Dicionário etimológico Nova Fronteira da língua portuguesa. Rio de Janeiro: Nova Fronteira, 1997.

CUNHA, C.; CINTRA, L L. Nova gramática do português contemporâneo. 2. ed. Rio de Janeiro: Nova Fronteira, 2001.

GONÇALVES, A. A. G. Diacronia e produtividade dos sufixos -agem, -igem, -ugem, -ádego, -ádigo e -ádiga em português. 2009. Dissertação (Mestrado em Filologia e Língua Portuguesa) - Faculdade de Filosofia, Letras e Ciências Humanas, Universidade de São Paulo, São Paulo, 2009.

HALLE, M., VERGNAUD, J. R. An essay on stress. Cambridge, MA: The MIT Press, 1987.

HAYES, B. Metrical Stress Theory: Principles and Case Studies. Chicago: The University of Chicago Press, 1995.

HOUAISS, A.; VILLAR, M. (Org.) Dicionário eletrônico Houaiss da língua portuguesa. Versão 1.0. Rio de Janeiro: Objetiva, 2015.

MAGALHÃES, J. S. O acento dos não verbos em português brasileiro no plano multidimensional. Alfa, São Paulo, v. 52, n. 2 405-430, 2008. Disponível em: <https://periodicos.fclar.unesp.br/alfa/article/view/1525/1232>. Acesso em: 15 ago. 2020.

MASSINI-CAGLIARI, G. Do poético ao linguístico no ritmo dos trovadores: três momentos da história do acento. São Paulo: Cultura Acadêmica Editora, 1999.

PEREIRA, R. V.; SILVESTRE, J. P.; VILLALVA, A. Os adjetivos em -vel formados em português: estrutura argumental, estrutura temática e aspeto da base verbal. ReVEL, v. 11, n. 20, 2013. 
SARAIVA, F. R. S. Novíssimo dicionário latino-português. Rio de Janeiro: Livraria Garnier, 1993.

SELKIRK, E. The Syllable. In: HULST, H. V. d.; SMITH, N. (Eds). The Structure of Phonological Representations: Part II. Dordrecht: Foris, 1982.

SOUZA, L. D. de. Fontes do Acento Paroxítono do Português Brasileiro. 2019. 153f. Dissertação (Mestrado em Estudos Linguísticos), Universidade Federal de Uberlândia, Uberlândia, MG, 2019.

WETZELS, L. Mid Vowel Neutralization in Brazilian Portuguese. Cadernos de Estudos Linguísticos, Campinas, 23, p. 19-55, 1992. Disponível em: <https://periodicos.sbu.unicamp.br/ojs/index.php/cel/article/ view/8636844/4565>. Acesso em: 10 ago. 2020. 


\section{MODELOS DE PERCEPÇÃO DE SONS DE LÍNGUAS NÃO NATIVAS: CONTRIBUIÇŐ̉ES PARA A DISCUSSÃO SOBRE PRIMITIVOS FONOLÓGICOS'}

Ubiratã Kickhöfel Alves

\section{Introdução}

Nos últimos 10 anos, temos verificado um aumento expressivo no número de estudos voltados ao mapeamento do processo de desenvolvimento ${ }^{2}$ fonético-fonológico de línguas não nativas ${ }^{3}$. Se, há praticamente 20 anos, os trabalhos referentes ao componente fonético-fonológico de uma nova língua ocupavam o status de "tema de estudos adicional" dentre as diversas questões de investigação de foneticistas e fonólogos brasileiros, atualmente, encontramos grupos de pesquisa que se dedicam clara e exclusivamente aos sons da L2. Reflete-se, assim, o crescimento de um tema de estudos bastante profícuo.

O referido aumento, além de ser resultado dos próprios avanços nas áreas de Fonética e Fonologia, caracteriza-se, também, como efeito das diferentes interfaces que as pesquisas que envolvem o componente sonoro têm estabelecido com outras subáreas da Linguística, dentre as quais podemos destacar a Psicolinguística e a Linguística Aplicada. Em meio a esse universo interdisciplinar e a uma grande diversidade epistemológica, pesquisadores com diferentes concepções de língua dedicam seus estudos à cadeia sonora. Apesar de tal diversidade, consideramos que, entre todos os intelectuais voltados ao estudo

1 Agradeço às audiências dos eventos 'Abralin 50' (Maceió, maio de 2019) e '5a Jornada de Estudos da Linguagem' (Pelotas, setembro de 2019), pela interlocução que deu origem à formulação do presente trabalho. $O$ projeto de pesquisa que deu origem a este artigo teve o apoio da FAPERGS, através do Edital Pesquisador Gaúcho 2017 (Processo 17/2551-0001000-00).

2 O emprego do termo 'desenvolvimento', ao invés do tradicional e já arraigado termo 'aquisição', não é realizado em vão, pois expressa o fato de que o processo de construção de um novo sistema sonoro ocorre ao longo de toda a vida do indivíduo (cf. Larsen-FReeman, 2015).

3 Para fins deste trabalho, não serão realizadas diferenciações entre os termos 'Língua Não Nativa' (LNN), 'Língua Adicional' (LA), 'Segunda Língua'(L2) ou 'Línguas Estrangeiras' (LE), de modo que tais termos e suas siglas venham a ser empregados de forma intercambiável. 
do desenvolvimento de sons de uma nova língua, uma premissa fundamental é compartilhada: a teorização em Fonologia (independentemente de qual concepção de Fonologia se esteja defendendo) fundamenta os estudos de L2, ao mesmo tempo em que os próprios estudos de L2 prestam uma contribuição importante à Teoria Fonológica.

Dado tamanho crescimento, consideramos fundamental uma discussão acerca de como os estudos fonológicos, sobretudo os referentes à Fonologia de Laboratório (Beckman; Kingston 2012; Cohn, 2010; Cohn; Fougeran; Huffman, 2011), contribuíram para o aumento do número de investigações sobre o sistema de L2. Julgamos pertinente, também, refletir sobre como os resultados das investigações da área contribuem com os próprios estudos fonológicos. Já há mais de 10 anos, em nossa Tese de Doutorado, afirmávamos que

(...) devemos deixar clara nossa conviç̧ão de que o avanço da Teoria Fonológica se mostra de grande valia para estudos mais aplicados, como os que se voltam para o entendimento do sistema fonológico em construção do aprendiz de segunda língua. Mais do que isso, acreditamos que a relação entre as áreas é bilateral: se por um lado os modelos de análise fonológica fornecem insumos teóricos a partir dos quais os estudos de aquisição (tanto de L1 como de L2) irão se fundamentar, ao mesmo tempo os estudos de aquisição podem e devem fornecer evidências empíricas que corroborem os princípios estabelecidos teoricamente pela ciência fonológica. De fato, é preciso que os procedimentos analíticos adotados nos estudos de aquisição da linguagem sejam considerados, também, como fontes de insumo teórico para que se possam fortalecer, e até mesmo repensar, os postulados da análise fonológica formal. (A, 2008, p.15-16)

Apoiados na afirmação acima, e com base nas pesquisas que temos realizado sobretudo na última década, verificamos que, mais do que sugerir alterações aos modelos já estabelecidos, os estudos sobre o desenvolvimento de uma nova língua contribuem efetivamente para a reflexão acerca dos primitivos abstratos e dos próprios limites entre Fonética e Fonologia. Em meio a essas discussões, e dado o caráter de interface propiciado sobretudo pela Fonologia de Laboratório, afirmamos, em 2015, que 
[...] pensar no dado de aquisição de L2/LE implica conjugar um grande número de saberes que se agregam a outras áreas da Linguística, de modo que os estudos sobre a aquisição de sons de uma nova língua muito têm a crescer com a colaboração teórica interdisciplinar. Por sua vez, não há dúvidas de que a área de Aquisição Fonético-Fonológica de L2/LE vem adquirindo o status de um ramo autônomo nos estudos linguísticos. Nesse sentido, os estudos em Aquisição Fonético-Fonnológica de L2/LE não somente recebem contribuições dos diversos outros campos da Linguística, mas, também, prestam aporte teórico-metodológico e empírico a essas áreas. (Alves; Cardoso, 2015, p.9)

As considerações acima feitas refletem o que consideramos ser as duas premissas basilares do presente trabalho: $(i)$ os dados de percepção e produção de L2 constituem uma fonte empírica pertinente de teorização; (ii) os estudos sobre os sistemas de sons de L2 não apenas recebem, mas também fornecem informações para outros campos da Linguística, dentre os quais se encontram os estudos fonológicos.

Consideramos que foi sobretudo com uma maior maturidade dos estudos de Fonologia de Laboratório que, no cenário de pesquisas de L2, diferentes maneiras de se pensar o dado sonoro de uma nova língua foram sendo propostas no âmbito acadêmico. Isso se deve porque a Fonologia de Laboratório não corresponde a uma única teoria, mas, sim, caracteriza-se como um posicionamento metodológico, conforme nos explica Albano:

A Fonologia de Laboratório é uma posição metodológica dentro da Fonologia que afirma que o estudo das representações fonológicas deve incluir o método experimental. Não se trata, pois, de uma teoria fonológica e, sim, de uma abordagem aplicável a qualquer teoria cuja concepção entre as relações entre a Fonética e a Fonologia seja suficientemente clara para embasar hipóteses experimentais. (Albano, 2017, p.169)

Dessa posição metodológica, fazem-se possíveis diferentes proposições de modelos e explicações teóricas, com epistemologias, inclusive, bastante distintas: 
As atividades de pesquisa dentro da Fonologia de Laboratório envolvem a cooperação de pessoas que podem discordar acerca da teoria de fonologia, mas que compartilham uma preocupação em fortalecer as bases científicas da fonologia através de uma metodologia aperfeiçoada, de modelagem explícita, e de uma construção cumulativa de resultados. Todos esses objetivos, conforme argumentamos, refletem a convicção de que a fonologia é uma das ciências naturais, e de que todos os aspectos da língua, o que inclui desde características específicas de língua à variação sociolinguística, são parte do mundo natural. ${ }^{4}$ (Pierrehumbert; Beckman; Ladd, 2000 [2012, p.18])

A partir das premissas da Fonologia de Laboratório, dentre as diversas questões de pesquisa que chamam a atenção dos pesquisadores que estudam o desenvolvimento de L2, um tema cada vez mais instigante diz respeito aos processos envolvidos na percepção de novos sons. Sobretudo em função da grande contribuição que representou a criação do software TP (RAUBER et al., 2013), desenvolvido em solo brasileiro, encontramos, em número cada vez maior em nosso país, estudos empíricos que se voltam à verificação da capacidade de identificação e discriminação dos sons da L2 por aprendizes brasileiros. Para fundamentar empiricamente esses estudos empíricos, encontramos uma série de proposições e modelos teóricos (Flege, 1995; Best, 1995; Polka; Bohn, 2003; 2011; Escudero; Boersma, 2004; Escudero, 2005, 2009; Best; Tyler, 2007; Boersma, 2007; 2011; Boersma; Hamann, 2009; Strange, 2011; Perozzo, 2017a; Flege; Bohn, 2020), cujas bases vão desde explicações de caráter psicolinguístico até propostas de teor plenamente formal.

Dada a quantidade considerável de modelos perceptuais de L2, elaborados a partir de distintas concepções, não é de surpreender que os pesquisadores se encontrem confundidos sobretudo no que diz respeito às diferenças (não somente operacionais, mas sobretudo de base epistemológica) entre tais proposições. Em

4 Do original, em inglês: Research activities within laboratory phonology envolve the cooperation of people who may disagree about phonological theory, but who share a concern for strengthening the scientific foundations of phonology through improved methodology, explicit modeling, and cumulation of results. These goals, we would argue, all reflect the belief that phonology is one of the natural sciences, and that all of language, including language-specific characteristics and sociolinguistic variation, is part of the natural world. 
função de tal natural dificuldade, é bastante comum que, tanto nacional quanto internacionalmente, os estudiosos acabem vindo a considerar todos os modelos de forma agregada. Dentro desse cenário, não há uma preocupação em discutir as capacidades de cada modelo, os seus diferentes posicionamentos epistemológicos e, sobretudo, o próprio primitivo de análise trazido por cada uma das propostas.

Frente a tal quadro, em nosso grupo de pesquisa, temos desenvolvido uma série de trabalhos (Alves; Silva, 2016; Perozzo; Alves, 2016; Perozzo, 2017a, 2017b; Alves; Brisolara, 2020) voltados à discussão teórica das bases epistemológicas que sustentam os principais modelos perceptuais adotados nas pesquisas brasileiras. A partir de tais estudos, consideramos não ser possível agrupar diferentes propostas perceptuais que acabam por lidar, por exemplo, com diferentes primitivos ou concepções acerca do que compreende a representação fonológica.É importante, pois, que tais diferenças se façam claras, sobretudo para que os investigadores se encontrem cientes das concepções distintas de Língua e de Fonética e Fonologia que regem tais modelos.

Dada a importância de maiores esclarecimentos acerca das bases epistemológicas de cada proposta, no presente capítulo discutiremos os pressupostos epistemológicos de três conjuntos de modelos amplamente difundidos no Brasil: (i) o Speech Learning Model (Flege, 1995) e sua versão atualmente revista, o Revised Speech Learning Model (Bohn; Flege, 2020); (ii) o Perceptual Assimilation Model (Best, 1995), sobretudo em sua versão voltada aos dados de L2 (Best; Tyler, 2007) e a sua subsequente reformulação, proposta por Perozzo (2017a); e (iii) a proposta original do Modelo L2 Linguistic Perceptual Model (L2LP - Escudero; Boersma, 2004; Escudero, 2005), bem como a posterior proposta de estrutura bidirecional de gramática proposta no Bidrectional Phonology and Phonetics Model - BIPHON (Boersma, 2007; 2011; Boersma; Hamann, 2009). Nossa tarefa não será, aqui, a de discutir os aspectos metodológicos ou princípios básicos das arquiteturas dos referidos modelos; visamos, sim, a discutir as suas teorias de base, sobretudo no que concerne ao primitivo fonológico defendido em cada proposta ${ }^{5}$. Verificamos que, embora os três gru-

5 Cabe mencionar, também, que a discussão das teorias de base será restrita aos aspectos previstos explicitamente nos textos fundadores referentes aos modelos de L2 em questão. Para uma discussão mais abrangente das diferentes concepções de percepção da fala, sobretudo no que concerne à abordagem psicoacústica e à Teoria do Realismo Direto, sugerimos a leitura de Nishida (2012). 
pos de modelos se refiram a um mesmo objeto de análise (fenômenos perceptuais na L2) ${ }^{6}$, cada um deles não somente reflete visões diferentes do processo de desenvolvimento linguístico, mas também concebe diferentes unidades de percepção da fala, podendo variar, conforme já afirmamos, desde uma visão de caráter psicolinguístico (cf. Flege, 1995; Flege; Bohn, 2020) até uma perspectiva de formalização da gramática (cf. Boersma, 2007; 2011; Boersma; Hamann, 2009). No que segue, discutiremos cada uma dessas proposições.

\section{O Speech Learning Model (Flege, 1995) e o Revised Speech Learning Model (Flege; Bohn, 2020): uma visão psicoacústica}

No que diz respeito ao primitivo e à concepção de percepção do Speech Learning Model (Flege, 1995), ainda que não expresso explicitamente nos textos fundadores do modelo, tal proposta se estabelece a partir de uma visão psicoacústica de desenvolvimento linguístico. Em uma concepção psicoacústica, a informação do sinal acústico permite que o ouvinte depreenda a existência de um contraste fonológico (WRIGHT, 2001, 2004):

O sinal acústico é produzido por articulações que são contínuas e sobrepostas em um maior ou menor grau; portanto, as pistas acústicas resultantes variam com o contexto. Essa variação contextual é um fator que contribui com a redundância no sinal, o que torna a percepção da fala possível mesmo em ambientes em que a audição é difícil. A variação no sinal devido à coarticulação é desejável, uma vez que também fornece ao ouvinte informações valiosas sobre taxa de elocução ou sobre o relativo grau de previsibilidade ou de novidade da informação semântica no sinal, e também acerca das características lexicais da palavra falada.? (Wright, 2004, p.36)

6 É importante considerar que o BIPHON (Boersma, 2007; 2011; Boersma; Hamann, 2009), ao contrário das outras propostas, não é um modelo elaborado exclusivamente para a verificação de dados de L2, podendo ser usado, inclusive, em estudos sobre a relação entre percepção e produção em sistemas de língua materna (cf. Quintanilha-Azevedo, 2016). Dada a sua proximidade ao modelo L2LP e sua utilização em vários estudos realizados no cenário brasileiro, optamos, entretanto, por aprofundar a sua discussão. Para uma análise perceptual de L2 à luz do BIPHON, veja-se Motta-Avila (2017).

7 Do original, em inglês: The acoustic signal is produced by articulations that are continuous and overlapping to a greater or lesser degree; therefore, the resulting acoustic cues vary with context. This 
Conforme as palavras de Holt (2012), a noção de percepção categórica à luz de uma abordagem psicoacústica pode ser expressa, portanto, a partir da seguinte forma:

Para extrair uma mensagem a partir da cadeia de fala, os ouvintes devem realizar duas tarefas perceptuais. Eles devem discriminar a variedade acústica linguisticamente relevante e generalizar no que diz respeito à variabilidade irrelevante. Dito de outra forma, os ouvintes devem categorizar a fala de um modo específico à sua língua (...). Uma vez que o mapeamento da variabilidade acústica é específico de língua, tais categorias devem ser aprendidas a partir da experiência com a fala. ${ }^{8}$ (Holt, 2012, p.348)

Em outras palavras, o primitivo basilar de análise do modelo diz respeito aos próprios aspectos acústicos da fala, tais como F1 e F2, por exemplo. Por esse motivo, tal concepção pode vir a ser considerada como de natureza puramente psicolinguística (ou, até mesmo, como puramente fonética). É importante mencionar, entretanto, que apesar do primitivo fonético, o modelo é capaz de se referir a categorias que apresentam status funcional ou fonológico (como no caso, por exemplo, de um aprendiz falante de Espanhol frente à tarefa de aprender a distinção entre vogais médias-baixas e médias-altas do Português Brasileiro, tal como nos pares representados por / $\varepsilon /$ vs. /e/ ou / / / vs. /o/). Ainda no que diz respeito à base acústica do modelo, a previsibilidade de formação de novas categorias de línguas adicionais encontra-se relacionada à semelhança (referente à proximidade acústica) entre as categorias da língua materna (L1) e da L2. De acordo com o Speech Learning Model, quanto maior a dissimilaridade fonética percebida entre o som da L2 e o som da L1 mais próximo, mais provável será de as diferenças entre tais sons serem discernidas.

contextual variation is a factor that contributes to the redundancy in the signal that makes speech perception possible even in difficult listening environments. The variation in the signal due to coarticulation is desirable also because it provides the listener with valuable information about speaking rate or about the relative novelty or predictability of semantic information within the signal, or about the lexical characteristics of a spoken word.

8 Do original, em inglês: To extract a message from speech, listeners must accomplish two complementary perceptual feats. They must discriminate linguistically relevant acoustic variability and generalize across irrelevant variability. To put it another way, listeners must categorize speech in a manner specific to their language (Lotto 2000). Since the mapping of acoustic variability is language-specific, these categories must be learned from experience with speech. 
Muitas são as críticas, encontradas na literatura, advindas de uma falta de critérios explícitos para definir quais aspectos constituiriam tal "proximidade" entre segmentos. Consideramos, a partir da análise da proposição dos textos fundadores da proposta, que a "proximidade" em questão deve ser considerada, também, referente à própria distância acústica entre as categorias da L1 e da L2. Sendo isso verdadeiro, no que diz respeito às vogais, por exemplo, o mapeamento de distâncias euclidianas ${ }^{9}$ contribuiria para determinarmos o grau de semelhança entre as categorias vocálicas. De acordo com as previsões do modelo, categorias da L2 muito semelhantes às da L1, já fortemente estabelecidas, serão "assimiladas” à língua materna (do que decorre, também, uma produção em L2 com sotaque da L1). Cabe mencionar, ainda, que o modelo prevê a possibilidade de dissimilação, que ocorre quando duas categorias acabam por se afastar acusticamente, de modo que cada uma delas ocupe um lugar distinto do original no espaço acústico, para que os contrastes das categorias fonológicas sejam preservados.

A noção psicoacústica insere-se em um campo epistemológico maior de cognição e de concepção de língua, a partir do qual a língua é vista como uma entidade de 'domínio geral' (do inglês, domain-general), de modo que o conhecimento linguístico não seja visto de forma diferenciada de outras formas de conhecimento. Diehl, Lotto e Holt (2004) denominam tal concepção como 'Abordagem Geral de Percepção'. Segundo explicam tais autores, a Abordagem Geral não invoca mecanismos especiais ou módulos para explicar a percepção acústica. Pelo contrário, ela assume, como hipótese de trabalho, que os sons da fala são percebidos com os mesmos mecanismos auditivos e perceptuais que têm evoluído desde os nossos ancestrais. No que diz respeito à percepção de categorias sonoras, os autores buscam evidências em animais para provar que tal categorização não é particular da linguagem humana, de modo a descartar a hipótese de um módulo específico de linguagem. Diehl, Lotto e Holt (op. cit.) também discutem fenômenos coarticulatórios, argumentando que tampou-

9 A distância euclidiana corresponde a uma medida de dissimilaridade que indica a distância entre dois pontos em um plano cartesiano. Considerando-se o trapézio vocálico, cada ponto é estabelecido a partir do valor de F2, no eixo horizontal, e do valor de F1, no eixo vertical. 
co esses constituem evidência de um módulo especificamente linguístico. Os autores apresentam, ainda, dados empíricos que apresentam interações entre dados sonoros de fala e outros tipos de insumo sonoro, o que também serve de argumento contra um módulo específico de percepção.

Ainda dentro das teorias psicoacústicas de percepção, uma discussão bastante pertinente diz respeito ao papel das diversas pistas acústicas que caracterizam os segmentos. Embora uma unidade como o segmento seja caracterizada por uma multiplicidade de pistas acústicas (cujo efeito conjunto propicia a percepção), no que diz respeito às distinções entre os elementos sonoros de uma dada língua, cada sistema seleciona pistas acústicas prioritárias para dar conta de tais diferenciações. Esse fenômeno referente ao peso de pistas, resolvido com grande facilidade dentro da visão psicoacústica, mostra-se pertinente a todas as propostas de percepção que visam a debater de que modo o recorte do aspecto físico é levado em consideração nas oposições funcionais de cada sistema linguístico. Dentro da visão psicoacústica, Holt e Lotto (2006) propõe uma discussão sobre o que denominam de 'cue weighting', ou peso de pistas, para dar conta de tal fato:

Simplesmente, algumas dimensões acústicas desempenham um papel maior do que outras ao determinar a identidade perceptual de um som. O fato de que as dimensões acústicas não necessitam contribuir de forma equivalente para a identidade das categorias tem sido referido como 'peso de pistas' (cue weighting). As dimensões acústicas parecem ser "pesadas" no sentido de que algumas parecem ser fortemente correlacionadas às respostas de categorização, enquanto outras, embora presentes, determinam o pertencimento à categoria percebida de forma bastante frágil. ${ }^{10}$ (Holt; Lotto, 2006, p.3059)

As considerações acima feitas são particularmente pertinentes para o cenário de estudos de L2, uma vez que o desenvolvimento de uma nova língua pode implicar uma diminuição do "peso" da pista prioritária da L1 a favor de

${ }^{10}$ Do original, em inglês: Simply put, some acoustic dimensions play a greater role in determining the perceptual identity of a sound than do others. The fact that acoustic dimensions need not contribute equivalently to category identity has been referred to as cue weighting. Acoustic dimensions appear to be perceptually weighted in the sense that some are strongly correlated to categorization responses whereas others, although present, weakly determine perceived category membership. 
outra pista da L2 que não necessariamente ocupa papel pertinente no sistema de língua materna. Tal é o caso do VOT Positivo, por exemplo. A referida pista, ainda que fundamental para a distinção entre plosivas surdas e sonoras iniciais entre ouvintes nativos do inglês, acaba por não exercer efeitos nas decisões de aprendizes argentinos e brasileiros, sobretudo frente a elementos manipulados em que as demais pistas acústicas do segmento original se encontram mantidas (Alves; Motta, 2014; Schwartzhaupt; Alves; Fontes, 2015; Alves; Zimmer, 2015; Alves; Luchini, 2016, 2017; 2020a 2020b; Alves; Luchini; Motta-Ávila, 2019; Alves; Kampff, 2019). Dentro desse cenário, a proposta de Holt e Lotto (2006) abarca, a partir da já denominada 'Abordagem Geral da Percepção', tanto dados de L1 quanto de L2, além de explicar com elegância fenômenos desenvolvimentais. Trata-se de considerações que, dado o primitivo acústico adotado, não implicam dificuldades ou desafios epistemológicos aos seguidores de uma concepção psicoacústica ${ }^{11}$. Essa noção é bastante importante para o Speech Learning Model, tendo recobrado importância sobretudo nas análises desenvolvidas à luz do modelo na última década.

Recentemente, Flege e Bohn (2020) publicaram um manuscrito, nas plataformas de compartilhamento de trabalhos acadêmicos, denominado The Revised Speech Learning Model (SLM-r). Tal texto, ainda sujeito a modificações antes de sua efetiva publicação, visa a propor uma versão revista ao Speech Learning Model (1995), após mais de 25 anos de sua formulação. Dado que a referida proposta ainda se encontra sob o status de pre-print, não iremos nos debruçar, neste trabalho, nos pormenores referentes às diferenças entre a proposta original e a sua atualização. Cabe dizer que, na referida revisão, o caráter psicoacústico da proposta é ainda mais explicitamente descrito do que no texto da década de 90. Consideramos que, também de maneira mais explícita, à proposta do SLM-r são incorporadas considerações referentes ao papel de pistas prioritárias e ao próprio modelo de 'cue weighting' (Holt; Lotto, 2006; Holt, 2012). Dentre as mudanças previstas pela versão revista da proposta, encontramos, sobretudo, sugestões

${ }^{11}$ Entretanto, conforme veremos na próxima seção, tal questão não é tão facilmente resolvida por todos os modelos perceptuais, sobretudo pelo Perceptual Assimilation Model-L2 (Best; Tyler, 2007). 
referentes à metodologia de coleta de dados, uma vez que, na nova versão, são priorizadas verificações individuais, de caráter longitudinal ${ }^{12}$.

Como qualquer proposição teórica, o Speech Learning Model e a sua versão revista encontram uma série de desafios, relacionados, sobretudo, à natureza piscoacústica do primitivo defendido em tais proposições. Uma das principais questões passíveis de discussão diz respeito ao que Strange (1995) denomina de 'Constancy Problem'. Tal "problema” de ordem teórica advém da grande variabilidade dos dados acústicos, de modo que, se o acústico constituir o próprio primitivo fonológico, corre-se o risco de contarmos com um número praticamente infinito de representações. Em outras palavras, é indiscutível o fato de que não há uma relação biunívoca entre os padrões acústicos e as categorias fonêmicas, pois não poderá haver uma representação específica para cada instância acústica.

Para lidar com esse possível problema, o modelo conta, em todos os seus trabalhos, com previsões de categorias que abrangem uma dada franja de valores acústicos, como, por exemplo, um espaço acústico específico para cada vogal dentro do trapézio vocálico. É justamente essa noção de "espaços acústicos" que permite, inclusive, que o modelo preveja que sons mais próximos sejam tidos como mais dificultosos para a percepção por parte do aprendiz estrangeiro.

Questões adicionais que desafiam a visão piscoacústica (e, por conseguinte, ambas as versões do Speech Learning Model) dizem respeito ao desafio de dar conta da multimodalidade da percepção da fala, bem como a tarefa de explicar os fatos referentes ao status de maior ou menor peso/prioridade que uma certa pista acústica pode assumir em uma dada língua do mundo. No que diz respeito à primeira questão, consideramos que, ao se associarem os aspectos psicoacústicos a uma Abordagem Geral de Percepção (cf. Diehl; Lotto; Holt, 2004), é possível fazer com que tal primitivo seja visto em ação com outros elementos, através de um aprendizado probabilístico e de um processamento

${ }^{12}$ Ainda que não explicitamente expresso no texto da proposta, consideramos que tal metodologia vai ao encontro daquela defendida pelos teóricos da concepção de Língua como Sistema Dinâmico Complexo (De Bot; Lowie; Verspoor, 2007; Larsen-Freeman; Carmeron, 2008; De Bot, 2015; 2017; Larsen-Freeman, 2017, Lowie, 2017, dentre outros), a partir da qual o lócus da análise é o indivíduo e o foco da verificação do processo de desenvolvimento é o acompanhamento de mudanças no sistema ao longo do tempo. 
distribuído, reforçando o caráter de 'domínio geral' da percepção. No que diz respeito à segunda questão, conforme já afirmado, consideramos que modelos como o de 'cue weighting' (Holt; Lotto, 2006; Holt, 2012), incorporado explicitamente, sobretudo, no modelo revisto de 2020 (Flege; Bohn, 2020), pode dar conta de diversos questionamentos anteriormente feitos ao modelo. É preciso dizer, por sua vez, que todas essas soluções convergem em uma concepção de linguagem do tipo 'domínio geral', em que os elementos linguísticos são igualados aos demais aspectos do ambiente. É importante, portanto, que o pesquisador se mostre ciente de tal fato, ao optar pelo modelo em questão.

\section{O gesto como primitivo perceptual: o Perceptual Assimilation Model-L2 (BEST; TYLER, 2007) e a visão revista por Perozzo (2017a)}

Também dentro de um caráter de 'domínio geral', mas fazendo uso de um primitivo gestual (Browman; Goldstein, 1986; 1992), encontramos o Perceptual Assimilation Model (BEST, 1995). Essa formulação inicial do modelo, proposta para a análise de casos de assimilação ${ }^{13}$ de sons por parte de ouvintes ingênuos ${ }^{14}$, foi revisitada em 2007 para dar conta de contextos de aprendizagem (ouvintes não ingênuos de L2), de modo a ser proposto o Perceptual Assimilation Model-L2 (Best; Tyler, 2007). Em termos epistemológicos, o modelo é amparado em uma abordagem ecológica de percepção (Gibson, 1966; 1979), a partir da qual é proposta uma perspectiva Realista Direta de Fala (Fowler, 1986), que tem por base a noção de gestos articulatórios (Browman; Goldstein, 1986; 1992). Conforme explica Fowler (1986), gestos fonológicos são ações públicas do trato vocal, sendo tal unidade a moeda comum entre percepção e produção (Goldstein; Fowler, 2003).

É preciso considerar que a visão ecológica Gibsoneana, que serviu de base para as considerações de Fowler (1986), não concebe um módulo específico de linguagem. Além disso, conforme explicam Diehl, Lotto e Holt (2004,

${ }^{13} \mathrm{O}$ termo 'assimilação', neste texto, diz respeito à inclusão de um som não nativo dentro de uma categoria pré-existente da L1.

${ }^{14}$ Ouvintes ingênuos são aqueles que nunca tiveram exposição prévia à língua testada no experimento. 
p.153), o termo 'direto' indica que a percepção não é mediada por processos de inferência ou testagem de hipóteses; de fato, assume-se que a informação do input é rica o suficiente para especificar os gestos que estruturarão tal sinal. Conforme explica Nishida (2014, p.150), de acordo com a visão ecológica Gibsoneana, "percebemos necessariamente o nosso nicho de sobrevivência. Percebemos a fala (e o mundo em geral) de maneira real e direta, pois isso promove sobrevivência”.

A partir do acima expresso, ao se referir a tal abordagem realista direta de percepção, Escudero (2007, p.119) afirma que "o aprendiz adulto não tem representações mentais para perceber a fala, mas ao invés disso busca e extrai diretamente os padrões dos gestos articulatórios e as constelações gestuais para o sinal de fala”. Em nosso grupo de pesquisa, vários trabalhos têm sido desenvolvidos (Alves; Silva, 2016; Perozzo; Alves, 2016; Perozzo, 2017a; 2017b) para discutir, sobretudo, as bases epistemológicas desse modelo e os desafios impostos por tais bases epistemológicas. Um dos principais desafios diz respeito ao fato de que o Realismo Direto, pelo menos em seu cerne pensado por Gibson, defende uma proposta não mentalista (segundo a qual os aprendizes buscam e extraem diretamente os padrões de gestos articulatórios e constelações gestuais da fala). Considerado tal fato, é importante perguntar como podemos explicar o papel do conhecimento da L1 como responsável pelos processos de assimilação quando do contato com os sons da nova língua (afinal, pela teoria Gibsoneana, não haveria mediação). Conforme expresso em Alves e Silva,

[...] Gibson (1979, p.127) caracteriza sua proposta como uma hipótese radical, pelo fato de que, ao pressupor que os valores e os significados estão externos ao percebedor, deixa claro que tal percepção se dá de maneira direta, por meio do contato do indivíduo com o ambiente, através de sua relação de complementaridade e interação. (Alves; Silva, 2016, p.113)

Ao confrontarmos a noção de Realismo Direto Gibsoneano (a partir do qual, conforme já afirmamos, os eventos são processados diretamente, evitando-se a necessidade de representações intermediárias) e a adaptação de tal proposição prevista por Fowler (1986) para dar conta das unidades gestuais, 
a partir das discussões em nosso grupo de pesquisa, questionávamos o quão direto seria tal apropriação de elementos. Tal indagação se dá porque, na L2, os processos assimilatórios e dissimilatórios acontecem indiscutivelmente a partir da relação com a L1. Em outras palavras,

[...] considerando-se as possibilidades de assimilação previstas no PAM-L2, poderíamos pensar se estariam os indivíduos armazenando unidades gestuais abstratas na sua mente; se assim fosse, os casos de assimilação da língua alvo a categorias da L1 não seriam advindos de comparações entre o estímulo recém ouvido e o previamente armazenado, de modo que a representação abstrata prévia estaria exercendo efeito sobre os tipos de categorizações a serem realizadas como o novo estímulo de L2? Sendo afirmativa a resposta para esse questionamento, de que forma tal perspectiva de aquisição seria distinta de outra de caráter mais indireto? (Alves; Silva, 2016, p.114)

Uma resposta a esse questionamento é trazida na Tese de Doutorado de Perozzo (2017a). No trabalho em questão, com vistas a uma maior coerência epistemológica entre os âmbitos filosófico, linguístico-formal e cognitivo que regem o modelo, o autor propõe revisitar a proposta de Best e Tyler (2017). No âmbito filosófico do tripé epistemológico, Perozzo (2017a) sugere a substituição do 'Realismo Direto' pelo 'Realismo Indireto' (Jackson, 1977, 2010), uma vez que tal postura, ao considerar a função de elementos mediadores da percepção, consegue dar conta do papel da L1 na formalização da assimilação perceptual. No que diz respeito ao âmbito linguístico-formal, o autor aposta na concepção de gesto acústico-articulatório (Albano, 2001) como unidade primitiva, uma vez que, sob as previsões de Albano (2001, 2020), a relação de tal primitivo com outros componentes da gramática, tais como os morfológicos, pode ser fundamentada. As duas concepções supracitadas são interligadas a um referencial de base cognitiva (Gazzaniga et al. 2012; Kandel, 2014), a partir do qual Perozzo (2017a) defende o poder das representações como unidade basilar para que pensemos os fenômenos perceptuais. Conforme as palavras do autor, 
Reiteramos, portanto, que o gesto acústico-articulatório deva ser a unidade que permeia a percepção de novos elementos fônicos. Além disso, com base em Albano (2001), postulamos que, de fato, existe uma gramática fônica, abstrata e representacional, a qual opera com o gesto acústico-articulatório. Esse, por sua vez, corresponde a uma unidade de contrastes lexicais que se apresenta tanto de maneira abstrata (mental) como de maneira física (motora). A gramática fônica do aprendiz/percebedor não nativo, em nossa visão, se configura, pelo menos no que tange à percepção, como um espaço de constantes relações entre unidades sonoras prévias e novas, as quais podem ser mais ou menos estáveis a depender do uso do idioma-alvo. (Perozzo, 2017a, p.141)

A proposição de Perozzo (2017a) parece-nos destacar-se sobre a de Best e Tyler (2007), principalmente pela coerência entre os três eixos epistemológicos. Além de conceber o gesto acústico-articulatório, o autor abandona a escola filosófica do Realismo Direto defendida por Fowler (1986), Best (1995) e Best e Tyler (2007), e passa a aderir à proposição do Realismo Indireto (Jackson, 1977, 2010) para dar conta de um processo perceptual que envolve a ação da cognição e o papel de representações abstratas da L1, desenvolvidas ao longo de toda a vida do indivíduo.

Ao apresentarmos tais diferenças entre a proposta de Best e Tyler (2007) e a de Perozzo (2017a), cabe uma discussão sobre a concepção de língua e de primitivo fonológico sustentada por tais modelos. A uma primeira vista, tais propostas poderiam vir a ser consideradas semelhantes ao SLM, por também preconizarem uma concepção de 'domínio geral' para o desenvolvimento linguístico. Entretanto, ao considerarmos o PAM-L2 e a proposta de Perozzo (2017a), verificamos que os primitivos basilares que caracterizam o processo perceptual em tais propostas mostram-se bastante distintos da noção acústica defendida no SLM. Tal fato corresponde, portanto, a um aspecto importante, que nos impede de associarmos os modelos de Flege e as propostas de Best (1995), Best e Tyler (2007) e Perozzo (2017a) sob uma mesma con- 
cepção epistemológica, uma vez que a unidade basilar de Fonologia é diferente entre cada uma dessas proposições. Em outras palavras, enquanto o modelo de Flege investe em um primitivo psicoacústico, os de Best (1995) e Best e Tyler (2007) argumentam a favor de gestos articulatórios (Browman; Goldstein, 1986; 1992), ao passo que a reformulação proposta por Perozzo (2017a) aposta em gestos acústico-articulatórios (Albano, 2001; 2020). Consideramos ser esse, portanto, um aspecto fundamental, que precisa ser reconhecido entre os pesquisadores da área.

A proposta de Perozzo (2017a) é bastante recente, e, assim como a proposição de Best e Tyler (2007), encontra, também, uma série de desafios. Além dos desafios referentes ao estabelecimento de metodologias referentes a tarefas de identificação e discriminação que se mostrem epistemologicamente coerentes com a sua teoria de base (desafios esses que, a nosso ver, perpassam qualquer modelo perceptual), em Alves e Brisolara (2020) discorremos sobre uma questão ainda importante, a ser enfrentada tanto pelo PAM-L2 quanto por sua versão revista proposta em Perozzo (2017a). Tal questão refere-se à necessidade de explicar como se dá o estabelecimento de pistas (acústico-) articulatórias prioritárias em uma dada língua, bem como ao longo do processo de desenvolvimento de L2. Tal fato empírico, conforme já discutimos, foi abordado explicitamente na visão psicoacústica, a partir das proposições de 'cue weighting' (Holt; Lotto, 2006; Holt, 2012). Conforme veremos na próxima seção, os modelos de L2LP (Escudero; Boersma, 2004; Escudero, 2005, 2009) e BIPHON (Boersma, 2007, 2011; Boerma; Hamann, 2009) também darão conta da questão referente aos pesos de pistas, porém através da formalização de um sistema de gramática. Uma vez que a proposta de Perozzo (2017a) se estabelece a partir de uma consonância epistemológica entre três eixos, consideramos que o referido modelo tem potencial para estabelecer, nos próximos passos de sua proposição, uma explicação epistemologicamente coerente, que estabeleça uma ponte entre os critérios cognitivos e formais que o regem. 


\section{Propostas de gramática para a distinção entre Fonética e Fonologia: o modelo L2LP (Escudero; Boersma, 2004; Escudero, 2005, 2009) e o BI- PHON Model (Boersma, 2007, 2011; Boersma; Hamann, 2009)}

Com uma maior ênfase na própria arquitetura da gramática do que na representação em si, encontramos o L2LP (Escudero; Boersma, 2004; Escudero, 2005; 2009) e o Modelo Bidirecional de Processamento - BIPHON (Boersma, 2007, 2011; Boersma; Hamann, 2009). Nesta seção, iremos nos concentrar nesse último, por se tratar de um modelo que já embasou uma série de trabalhos de pós-graduação em nosso país (Quintanilha-Azevedo, 2016; Motta-Avila, 2017, dentre outros) $)^{15}$.

Conforme o próprio nome do modelo, a arquitetura do BIPHON prevê tanto percepção quanto produção a partir do mesmo sistema de gramática, formalizável através de um ranking de restrições. O estabelecimento desse ranking de restrições, conforme proposto na Figura 1, se dá a partir de um algoritmo de aprendizagem, tal como o Algoritmo de Aprendizagem Gradual (GLA: Boersma; Hayes, 2001). Apresentamos, na figura que segue, a estrutura da gramática no modelo BIPHON:

Figura 1 - Estrutura da gramática no Modelo BIPHON

\section{COMPREHENSION}

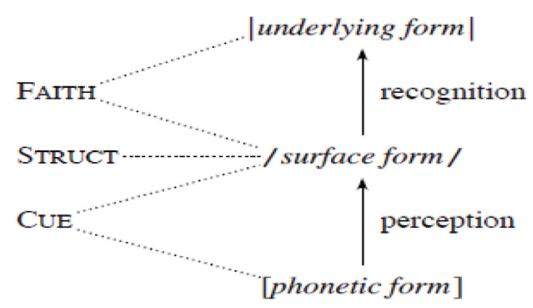

\section{PRODUCTION}

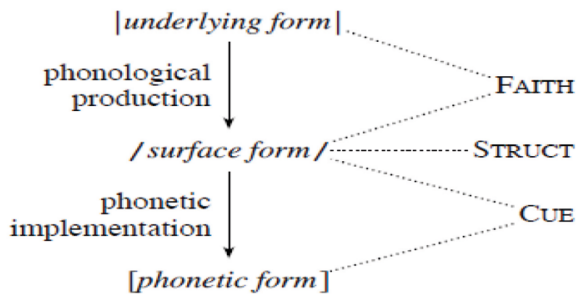

Fonte: Matzenauer e Quintanilha-Azevedo (2016, p.33)

Conforme pode ser visto na figura acima, ao contrário das duas propostas anteriores, concebe-se uma diferença entre níveis representacionais:

${ }^{15}$ Ainda que não nos concentremos no modelo L2LP, cabe mencionar que, em sua arquitetura original, tal proposta condiz com o módulo de percepção do modelo BIPHON (ou seja, com o lado esquerdo da arquitetura de gramática do referido modelo, conforme será visto na figura a seguir). 
a gramática, através do ranking de restrições, estabelece a interface entre as unidades de cada nível, de modo a formalizar a percepção e a produção como entes dessa gramática.

O modelo inclui três níveis de representação: um de natureza fonética (a [forma fonética]) e dois de natureza fonológica (a /forma de superfície/ e a |forma subjacente|). A partir desses níveis, conforme explicam Matzenauer e Quintanilha-Azevedo (2016, p.33), concebe-se um modelo "capaz de descrever como a linguagem discreta pode emergir, no processo de aquisição, a partir de um input gradiente". Conforme as palavras as autoras,

Das duas representações fonológicas, uma é a Forma Subjacente (Underlying Form - UF), que se constitui em uma sequência de estruturas fonológicas discretas associadas a morfemas no léxico; a outra é uma Forma Fonológica de Superfície (Surface Form - SF), que é uma estrutura fonológica que consiste de segmentos, traços, sílabas e pés. A Forma Fonética (Phonetic Form - PF) integra uma representação auditiva (pitches, formantes, silêncios e ruídos) e uma representação articulatória (conjunto de comandos musculares: língua, lábios, velum, faringe, laringe e pulmões) - na figura, essas duas (as representações auditiva e articulatória) estão colapsadas em uma única Forma Fonética. (Matzneuaer; Quintanilha-Azevedo, 2016, p. 33)

Para estabelecer a relação entre os níveis, as restrições devem, portanto, ser de três tipos: de fidelidade (que estabelecem a relação entre a /forma de superfície/ e a |forma subjacente|), de estrutura (que impõem restrições em determinadas estruturas da /forma de superfície/) e de pista (que se mostram responsáveis pela análise de pistas acústicas (ou articulações) e de sua relação com a /forma de superfície/). Apesar do aqui descrito, vê-se que esse último tipo de pista tem um status específico de língua. Trata-se de um modelo robusto de Fonologia, de interesse sobretudo aos pesquisadores que, ao conceberem a dicotomia entre o nível físico e o nível subjacente ou abstrato, desejam verificar a interação entre tais níveis de representação através de uma gramática formal. Concebemos que tal modelo formal deve, também, ser considerado dentro da Fonologia de Laboratório, por envolver todo um aparato referente 
à experimentação perceptual e à necessidade de se determinar os aspectos acústicos de sinal de fala (que correspondem, justamente, ao nível mais baixo da gramática, conforme expresso na figura referente à arquitetura do modelo).

Assim como o Speech Learning Model e ao contrário do Perceptual Assimilation Model-L2, o modelo em questão consegue dar conta da priorização de pistas acústicas na percepção de um dado segmento. Há de se considerar, entretanto, que, em termos epistemológicos, o mesmo fenômeno de peso de pistas é tratado de forma totalmente distinta: na visão psicoacústica, a própria pista representava o primitivo que daria conta do estabelecimento de oposições fonológicas. No BIPHON, por sua vez, o estabelecimento do peso de pistas se dá a partir de uma teoria de gramática. Mais do que isso, o papel prioritário de uma dada pista (seja ela de natureza acústica ou articulatória) se mostra relevante para o estabelecimento do segmento na /forma de superfície/, de modo que a relação entre esses dois níveis se faz formalizável pelas restrições de pista. Cabe mencionar que, no BIPHON, há um nível ainda mais abstrato do que o de superfície, uma vez que tal nível intermediário ainda não corresponde à estrutura subjacente do referido segmento. Dessa forma, o BIPHON constitui, portanto, um modelo que estabelece claramente a distinção entre os âmbitos da Fonética e Fonologia. Ressaltamos, uma vez mais, que tal tratamento não é previsto no modelo psicoacústico, pois o mecanismo para dar conta de categorias distintivas ou não (alofônicas) é justamente o mesmo, cabendo justamente ao caráter de 'domínio geral' do modelo (e não à sua formalização em si) a distinção do status funcional ou não dos sons. Consideramos que as considerações aqui feitas são importantes por justamente evidenciar como um mesmo fenômeno empírico pode ser tratado por dois modelos perceptuais, porém sob premissas epistemológicas bastante distintas e com explicações e tratamentos diferenciados.

Assim como os modelos anteriores, o BIPHON também encontra uma série de desafios. Consideramos que um dos principais entraves ao modelo diz respeito a uma dificuldade inerente a qualquer proposta de formalização do processo de construção de um ranqueamento de restrições a partir de um algoritmo de aprendizagem, tal como o GLA: a incapacidade de lidar, com fenômenos referentes à multidirecionalidade da influência interlinguística em 
sistemas multilíngues (cf. Pereyron, 2017). Dentre esses fenômenos, destacamos os estudos de atrito linguístico de língua materna (cf. Kupske, 2016; Schmid; Köpke, 2019), de acordo com o qual o sistema de L1 altera suas características ao ser influenciado por outros sistemas de língua adicional, conforme demonstram diversos trabalhos desenvolvidos por nosso grupo de pesquisa (Kupske; Alves, 2016; De Los Santos, 2017; De Los Santos; Alves, 2018; Schereschewsky; Alves; Kupske, 2017, 2019; Alves; Luchini; Scherechewsky, 2019; Schereschewsky; Alves, 2019; Pereyron; Alves, 2020).

A constatação acima expressa decorre do fato de que tanto o modelo L2LP quanto o BIPHON (bem como qualquer outra análise via ranqueamento de restrições) se estabelecem a partir de uma premissa de "cópia plena da gramática de percepção da L1 e das representações lexicais para formar as bases de um novo sistema perceptual de L2" (Escudero, 2007, p.126). Considerando-se tal fato, ao contrário do previsto pelo Speech Learning Model, a L1 e a L2, sob tal formalização, não compartilhariam um espaço fonológico comum, uma vez que constituiriam gramáticas independentes (sendo a L2 uma gramática que teve, como estágio inicial, uma cópia do ranqueamento da L1). Tal fato não permitiria explicar, através de uma teoria de gramática, a influência que a $L 2$ pode exercer na $L 1$, dada a independência entre esses dois sistemas, por configurarem hierarquias distintas. De fato, cabe mencionar que questões referentes a atrito linguístico não caracterizam uma questão de interesse por parte do paradigma de base que rege tal modelo de gramática.

\section{Conclusão}

Neste trabalho, refletimos acerca de três propostas perceptuais de L2, desenvolvidas à luz da Fonologia de Laboratório. Tais propostas variam por atribuir mais ênfase ou à representação, ou aos mecanismos de formalização da gramática. Além disso, conforme vimos na discussão individual de cada uma das três epistemologias, os modelos em questão refletem diferentes posicionamentos acerca do status do dado fonético frente à tradicional dicotomia 'Fonética-Fonologia', de modo que tenhamos desde modelos em que tal dicotomia se faz preser- 
vada (como o L2LP e o BIPHON) até propostas em que a referida divisão, em função do primitivo estudado, não se faz concebível (como os modelos com base em primitivos gestuais). Independentemente de se conceber ou não a distinção entre os dois domínios, concluímos que, em todas as propostas, o dado fonético se fez necessário e cobrou especial importância para a discussão em Fonologia. Tal fato vai ao encontro da concepção experimental que rege a Fonologia de Laboratório, conforme explicamos no início deste texto.

Ressaltamos que, mais do que um jogo de "quem pode mais", cada modelo encara diferentes desafios e limitações que são decorrentes das próprias arquiteturas específicas, bem como das próprias concepções de língua e de primitivos de Fonética e Fonologia que os sustentam. Nesse sentido, ainda que as três distintas proposições possam ser consideradas como excelentes representantes da área de Fonologia de Laboratório como um todo, destacamos, uma vez mais, que as próprias concepções de Fonologia das três proposições são particularmente distintas. No Speech Learning Model, as categorias fonológicas se estabelecem a partir do primitivo acústico. No Perceptual Assimilation Model-L2, a abstração fonológica é formalizada através do gesto articulatório (Best; Tyler, 2007) ou acústico-articulatório (PEROZZO, 2017a), de modo a prever um nível fônico que não prevê uma desassociação entre as tradicionais áreas de Fonética e Fonologia. Por sua vez, nos modelos L2LP e BIPHON, os domínios Fonético e Fonológico, ou físico e abstrato, mostram-se bastante claros, sendo sua relação regida por uma teoria de gramática.

Ao longo de toda a discussão, levantamos, também, os desafios a serem enfrentados por cada uma das propostas. Dentre as diversas questões empíricas que apontamos para destacar os distintos tratamentos oferecidos por cada um dos modelos, enfocamos a discussão referente à seleção (de caráter específico de língua) das pistas acústicas prioritárias para estabelecer as diferenças contrastivas entre os segmentos das línguas do mundo. Verificamos que, ainda que por vias bastante distintas (do processamento psicolinguístico e da formalização da gramática), os modelos de natureza psicoacústica e de gramática, por exemplo, conseguem dar conta de tal fato, aspecto esse que ainda se mostra desafiador para as proposições com base gestual. Por sua vez, demonstramos que, numa abordagem acústica, a questão do 'constancy problem' (Strange, 1995) 
continua sendo um desafio para o pesquisador. Já no que diz respeito a modelos de gramática como o L2LP e o BIPHON, em que a gramática de L2 tem, em seu estágio inicial, uma cópia do ranqueamento da L1 (de modo a caracterizar dois sistemas desvinculados), o desafio diz respeito a formalizar efeitos das línguas adicionais sobre a $\mathrm{L} 1$, inclusive em relação a casos em que bilíngues apresentam, para a L1, valores intermediários entre L1 e L2.

Novamente, destacamos não haver modelos "melhores" ou "piores", ou ainda "vencedores" ou "perdedores", uma vez que a epistemologia de cada proposta é distinta. É importante, entretanto, que o pesquisador saiba diferenciar as bases de cada uma dessas proposições, de modo a não pensar que, por virem a lidar com a mesma empiria perceptual, as possíveis soluções encontradas na literatura se mostram equivalentes no que diz respeito às suas teorias de base. Esse conhecimento, conforme já dissemos, é fundamental para todo e qualquer pesquisador envolvido com os dados de L2. Em outras palavras, ainda que o objeto de investigação - a resposta perceptual dos aprendizes - constitua o ponto de encontro entre os modelos, o modo como tal dado será explicado é, indiscutivelmente, abordado por diferentes lugares e posicionamentos dentro da Linguística.

Embora nem todos os modelos referidos tenham necessariamente um objetivo explícito de formalização, ou visem a situar tais discussões dentro de um modelo de Gramática, consideramos ser indiscutível o fato de que os preceitos de base das propostas aqui levantadas contribuem com as discussões referentes aos primitivos da Fonologia. Tal fato reforça, uma vez mais, que a Fonologia de Laboratório, ao teorizar sobre o dado obtido de estudos experimentais, pode abarcar diferentes posicionamentos teóricos. A partir da reflexão sobre essas diferentes concepções, reafirmamos nossa convicção, expressa no início deste capítulo, de que a análise dos sistemas de sons de L2 se alimenta dos preceitos das discussões basilares da Fonologia. Mais do que isso, é justamente nesse debate entre tais diferentes acepções que, sob nossa visão, são prestadas contribuições à própria teorização da área. Em outras palavras, ao se discutirem a natureza dos primitivos fonológicos e sua formalização, bem como a existência de limites ou não entre o físico e o abstrato, o estudo dos modelos de percepção de L2 contribui para discussões basilares dentro da própria Teoria Fonológica. 


\section{REFERÊNCIAS}

ALBANO, E. C. O gesto e suas bordas: esboço da Fonologia AcústicoArticulatória do Português Brasileiro. Campinas: Mercado de Letras/São Paulo - Fapesp, 2001.

ALBANO, E. C. Fonologia de Laboratório. In: HORA, D.; MATZENAUER, C. L. B. (Orgs.). Fonologia, Fonologias: uma introdução. São Paulo: Contexto, 2017. p.169-181.

ALBANO, E. C. O gesto audível: Fonologia como Pragmática. São Paulo: Cortez, 2020.

ALVES, U. K. A aquisição das sequências finais de obstruentes do inglês (L2) por falantes do Sul do Brasil: análise via Teoria da Otimidade. Tese (Doutorado em Letras) - Faculdade de Letras, Pontifícia Universidade Católica do Rio Grande do Sul, Porto Alegre, 2008.

ALVES, U. K.; BRISOLARA, L. B. Listening to accented speech in Brazilian Portuguese: on the role of fricative voicing and vowel duration in the identification of /s/ - /z/ minimal pairs produced by speakers of L1 Spanish. Journal of Portuguese Linguistics, Lisboa, v.19, n.1, 6, 2020.

ALVES, U. K.; CARDOSO, W. Apresentação. Organon, Porto Alegre, v.30, n.58, p.9-11, 2015.

ALVES, U. K.; KAMPFF, F. F. Efeitos de longo prazo do treinamento perceptual na percepção e produção das plosivas iniciais surdas do inglês por estudantes brasileiros: implicações para o ensino de pronúncia. Ilha do Desterro, Florianópolis, v.72, n.3, p.375-399, 2019.

ALVES, U. K.; LUCHINI, P. L. Percepción de la distinción entre oclusivas sordas y sonoras iniciales del inglés (LE) por estudiantes argentinos: datos de identificación y discriminación. Revista Lingüística (ALFAL), Montevideo, v.32, n.1, p.25-39, 2016. 
ALVES, U. K.; LUCHINI, P. L. Effects of perceptual training on the identification and production of word-final voiceless stops by Argentinean learners of English. Ilha do Desterro, Florianópolis, v. 70, n. 3, p.15-32, 2017.

ALVES, U. K.; LUCHINI, P. L. ¿Entrenamiento perceptivo o instrucción explícita? Percepción y producción de los patrones de Voice Onset Time iniciales del inglés (LE) por estudiantes brasileños. Forma y Función, Bogotá, v.33, n.2, p.133-165, 2020a.

ALVES, U. K.; LUCHINI, P. L. Desarrollo de los patrones de Voice Onset Time (VOT) del inglés (L2) por argentinos y brasileños: lo que ya sabemos y lo que todavía nos queda descubrir. In: LUCHINI, P. L.; ALVES, U. K. (Eds.). Cuestiones del Lenguaje: desarrollo le lenguas extranjeras, enseñanza y traducción. Mar del Plata: Editorial de la Universidad Nacional de Mar del Plata, 2020b. p.13-31.

ALVES, U. K.; LUCHINI, P. L.; MOTTA-AVILA, C. S. ¿'Pee' o 'Bee’? Identificación por oyentes argentinos y norteamericanos de oclusivas iniciales del inglés con diferentes duraciones manipuladas de Voice Onset Time. Signo, Santa Cruz do Sul, v.44, n.81, p.38-53, 2019.

ALVES, U. K; LUCHINI, P. L.; SCHERESCHEWSKY, L. C. L2 development and L1 attrition in an L1-dominant environment: analysing Voice Onset Time in L1 Spanish and L2 English. Estudos da Língua(gem), Vitória da Conquista, v.17, n.2, p.159-182, 2019.

ALVES, U. K.; MOTTA, C. S. Focusing on the right cue: Perception of voiceless and voiced stops in English by Brazilian learners. Phrasis - Studies in Language and Literature, Ghent (Belgium), v.50, p.31-50, 2014.

ALVES, U. K. SILVA, A. H. P. Implicações de uma perspectiva Realista Direta para o PAM-L2: desafios teórico-metodológicos. Revista do Gel, São Paulo, v.13, n.1, p.107-131, 2016. 
ALVES, U. K; ZIMMER, M. C. Percepção e produção dos padrões de VOT do inglês por aprendizes brasileiros: $O$ papel de múltiplas pistas acústicas sob uma perspectiva dinâmica. Alfa Revista de Linguística, Assis-SP, v.59, p.157-180, 2015.

BECKMAN, M. E.; KINGSTON, J. Introduction, Papers in Laboratory Phono$\operatorname{logy} \mathrm{I}$ : between the grammar and the physics of speech (reprint). In: COHN, A. C.; FOUGERON, C.; HUFFMAN, M. K. (Eds.). The Oxford Handbook of Laboratory Phonology. Oxford University Press, 2012. p.10-16.

BEST, C. A direct realist view of cross-language speech perception. In: STRANGE, W. (Ed.). Speech Perception and Linguistic Experience: theoretical and methodological issues in cross-language speech research. Timonium: York Press, 1995. p.167-200.

BEST, C; TYLER, M. D. Nonnative and second-language speech perception: commonalities and complementarities. In: BOHN, O.-S.; MUNRO, M. J. (Eds.). Language Experience in Second Language Speech Learning - in honor of James Emil Flege. Amsterdam: John Benjamins Publishing Company, 2007. p.13-34.

BOERSMA, P. Cue constraints and their interactions in phonological perception and production. Rutgers Optimality Archive, n. 944, 2007.

BOERSMA, P. A programme for bidirectional phonology and phonetics in their acquisition and evolution. In: BENZ, A.; MATTAUSCH, J. (Eds.). Bidirectional Optimality Theory. Amsterdam: John Benjamins, 2011. p.33-72.

BOERSMA, P.; HAMANN, S. Introduction: models of phonology in perception. In: BOERSMA, P.; HAMANN, S. (Eds.). Phonology in Perception. Berlin: Mouton de Gruyter, 2009. p.1-24.

BOERSMA, P.; HAYES, B. Empirical Tests of the Gradual Learning Algorithm. Linguistic Inquiry, Cambridge (Massachusetts), v.32, p.45-86, 2001. 
BROWMAN, C; GOLDSTEIN, L. Towards an Articulatory Phonology. Phonology Yearbook, Cambridge (U.K.), v.3, p.219-252, 1986.

BROWMAN, C.; GOLDSTEIN, L. Articulatory Phonology: an overview. Phonetica, Basel (Switzerland), v.49, n.3-4, p.155-180, 1992.

COHN, A. C. Laboratory Phonology: past successes and current questions, challenges, and goals. In: FOUGERON, C.; KÜHNERT, B.; D'IMPERIO, M.; VALLÉE, N. (Eds.). Laboratory Phonology 10. Berlin: Walter de Gruyter, 2010. p.3-29.

COHN,A.C.; FOUGERON, C.; HUFFMAN, M. Introduction.In: COHN, A. C.; FOUGERON, C.; HUFFMAN, M. K. (Eds.). The Oxford Handbook of Laboratory Phonology. Oxford: Oxford University Press, 2012. p. 3-9.

DE BOT, K. Rates of Change: Timescales in Second Language Development. In: DÖRNYEI, Z.; MacINTYRE, P. D.; HENRY, A. (Eds). Motivational Dynamics in Language Learning. Bristol: Multilingual Matters, 2015. p.29-37.

DE BOT, K. Complexity Theory and Dynamic Systems Theory: same or different? In: ORTEGA, L.; HAN, Z. (Eds.). Complexity Theory and Language Development: in celebration of Diane Larsen-Freeman. Amsterdam: John Benjamins Publishing Company, 2017. p.51-58.

DE BOT, K.; LOWIE, W.; VERSPOOR, M. A Dynamic Systems Theory approach to second language acquisition. Bilingualism: Language \& Cognition, Cambridge (U.K.), v.10, n.1, p.7-21, 2007.

DE LOS SANTOS, B. R. A produção da vogal átona final/e/por Porto-Alegrenses aprendizes de Espanhol como segunda língua (L2): uma investigação sobre atrito linguístico em ambiente de L2 não-dominante. Dissertação (Mestrado em Letras). Instituto de Letras, Universidade Federal do Rio Grande do Sul, Porto Alegre, 2017. 
DE LOS SANTOS, B. R.; ALVES, U. K. Explorando a possibilidade de atrito linguístico: uma análise acústica da produção da vogal átona final /e/ na variedade Porto-Alegrense do Português Brasileiro. Gradus: Revista Brasileira de Fonologia de Laboratório, Curitiba, v.3, n.1, p. 14-41, 2018.

DIEHL, R. L.; LOTTO, A. J.; HOLT, L. L. Speech Perception. Annual Review of Psychology, Palo Alto (CA), v.55, p.149-179, 2004.

ESCUDERO, P. Linguistic perception and second language acquisition: explaining the attainment of optimal phonological categorization. Tese (Doutorado). University of Utrecht, Utrecht, 2005.

ESCUDERO, P. Second Language Phonology: the role of perception. In: PENNIngTON, M. C. (Ed.) Phonology in Context. New York: Springer, 2007. p.109-134.

ESCUDERO, P. The linguistic perception of similar L2 sounds. In: BOERSMA, P.; HAMANN, S. (Eds.). Phonology in Perception. Berlin: Mouton de Gruyter, 2009. p.151-190.

ESCUDERO, P.; BOERSMA, P. Bridging the gap between L2 perception research and phonological theory. Studies in Second Language Acquisition, Cambridge (U.K.), v.26, n.4, p.551-585, 2004.

FLEGE, J. E. Second Language Speech Learning: Theory, findings, and problems. In: STRANGE, W. (Ed.). Speech perception and linguistic experience: Issues in cross-language research. Timonium, MD: York Press, 1995. p.233-277.

FLEGE, J. E.; BOHN, O.-S. The revised Speech Learning Model (SLM-r). Manuscrito (pre-print). Disponível em: https://www.researchgate.net/publication/342923320_The_revised_Speech_Learning_Model. Acesso em: 19 de setembro de 2020 . 
FOWLER, C. An event approach to the study of speech perception from a direct-realist perspective. Journal of Phonetics, Amsterdam, v.14, n.1, p.3-28, 1986.

GAZZANIGA, M.; HEATHERTON, T.; HALPERN, D.; HEINE, S. Psychological Science. New York: W.W. Norton \& Company, 2012.

GIBSON, J. J. The Senses Considered as Perceptual Systems. Boston: Houghton Miffin, 1966.

GIBSON, J. J. The Ecological Approach to Visual Perception. New York: Psychology Press, 1979.

GOLDSTEIN, L.; FOWLER, C. A. Articulatory Phonology: A Phonology for Public Language Use. In: SCHILLER, N.; MEYER, A. S. (Eds). Phonetics and Phonology in Language Comprehension and Production. Berlin: Mouton de Gruiter, 2003. p.159-207.

HOLT, L. L. How perceptual and cognitive constraints affect learning of speech categories. In: COHN, A. C.; FOUGERON, C.; HUFFMAN, M. K. (Eds.). The Oxford Handbook of Laboratory Phonology. Oxford: Oxford University Press, 2012.p.348-358.

HOLT, L. L.; LOTTO, A. J. Cue weighting in auditory categorization: implications for first and second language acquisition. Journal of the Acoustical Society of America, New York, v.119, n.5, p.3059-3071, 2006.

JACKSON, F. Perception. New York: Cambridge University Press, 1977.

JACKSON, F. Representative realism. In: DANCY, J.; SOSA, E.; STEUP, M. (Eds.). A companion to epistemology. 2. ed. Malden: Blackwell, 2010. p. 702-705.

KANDEL, E. Das células nervosas à cognição: As representações internas de espaço e ação. In: KANDEL, E.; SCHWARTZ, J.; JESSEL, T.; SIEGEL- 
BAUM, S.; HUDSPETHET, A. (Eds.). Princípios de neurociências. 5. ed. Porto Alegre: Artmed, 2014. p.327-344.

KUPSKE, F. F. Imigração, atrito e complexidade: a produção das oclusivas surdas iniciais do Inglês e do Português por Sul-brasileiros residentes em Londres. Tese (Doutorado em Letras). Instituto de Letras, Universidade Federal do Rio Grande do Sul, Porto Alegre, 2016.

KUPSKE, F. F.; ALVES, U. K. A fala de imigrantes brasileiros de primeira geração em Londres como evidência empírica para a língua como Sistema Adaptativo Complexo. Revista Virtual de Estudos da Linguagem (REVEL), Porto Alegre, v.14, n.27, p.173-202, 2016.

LARSEN-FREEMAN, D. Saying what we mean: Making a case for 'language acquisition' to become 'language development'. Language Teaching, Cambridge (U.K.), v.48, n.4, p.491-505, 2015.

LARSEN-FREEMAN, D. Complexity Theory: the lessons continue. In: ORTEGA, L.; HAN, Z-H. (Eds.). Complexity Theory and Language Development: in celebration of Diane Larsen-Freeman. Amsterdam: John Benjamins Publishing Company, 2017. p.11-50.

\section{LARSEN-FREEMAN, D. CAMERON, L. Complex Systems and Applied}

Linguistics. Oxford: Oxford University Press, 2008.

LOWIE, W. Lost in state space? Methodological considerations in Complex Dynamic Theory approaches to second language development research. In: ORTEGA, L.; HAN, Z-H. (Eds.). Complexity Theory and Language Development: in celebration of Diane Larsen-Freeman. Amsterdam: John Benjamins Publishing Company, 2017. p.123-141.

MATZENAUER, C. L. B.; QUINTANILHA-AZEVEDO, R. Teoria Fonológica e Aquisição de Língua Estrangeira. In: ALVES, U. K. (Org.). Aquisição 
Fonético-Fonológica de Língua Estrangeira: Investigações Rio-Grandenses e Argentinas em Discussão. Campinas: Pontes Editores, 2016. p.25-47.

MOTTA-AVILA, C. A formalização fonético-fonológica da percepção de plosivas surdas sob múltiplas manipulações de Voice Onset Time (VOT) por brasileiros e americanos à luz do Modelo "BiPhon”. Dissertação (Mestrado em Letras). Universidade Católica de Pelotas, Pelotas, 2017.

NISHIDA, G. Sobre Teorias de Percepção da Fala. Tese (Doutorado em Letras). Setor de Ciências Humanas, Universidade Federal do Paraná, Curitiba, 2012.

NISHIDA, G. As bases acústica e articulatória das teorias de percepção de fala. Revista do Gel, São Paulo, v.11, n.1, p.142-167, 2014.

PEREYRON, L. A produção vocálica por falantes de Espanhol (L1), Inglês (L2) e Português (L3): uma perspectiva dinâmica na (multi) direcionalidade da transferência linguística. Tese (Doutorado em Letras). Instituto de Letras, Universidade Federal do Rio Grande do Sul, Porto Alegre, 2017.

PEREYRON, L.; ALVES, U. K. Multi-directionality in language transfer: development of the vowel system of Brazilian Portuguese as a second (L2) or third language (L3). In: MOLSING, K. V.; PERNA, C. B. L.; IBAÑOS, A. M. T. (Eds.). Linguistic Approaches to Portuguese as an Additional Language. Amsterdam: John Benjamins Publishing Company, 2020. p.83-106.

PEROZZO, R. V. Sobre as esferas cognitiva, acústico-articulatória e realista indireta da percepção fônica não nativa: para além do PAM-L2. Tese (Doutorado em Letras). Instituto de Letras, Universidade Federal do Rio Grande do Sul, Porto Alegre, 2017a.

PEROZZO, R. V. Percepção fônica de línguas não nativas no arcabouço da cognição e do realismo indireto: complementaridade entre aspectos cognitivos 
e filosóficos a partir do PAM-L2. Gradus: Revista Brasileira de Fonologia de Laboratório, Curitiba, v.2, n.1, p.52-72, 2017b.

PEROZZO, R. V.; ALVES, U. K. Uma discussão acerca da aplicação do Perceptual Assimilation Model-L2 à percepção fônica de língua estrangeira: questões de pesquisa e desafios teóricos. Domínios de Lingu@gem, Uberlândia, v.10, n.2, p.733-764, 2016.

PIERREHUMBERT, J. B.; BECKMAN, M. E.; LADD, R. Conceptual foundations of phonology as a laboratory science (reprint). In: COHN, A. C.; FOUGERON, C.; HUFFMAN, M. K. (Eds.). The Oxford Handbook of Laboratory Phonology. Oxford: Oxford University Press, 2012. p.17-39.

POLKA, L. BOHN, O.-S. Asymmetries in vowel perception. Speech Communication, Amsterdam, v.41, n.1, p.221-231, 2003.

POLKA, L.; BOHN, O.-S. Natural Referent Vowel (NRV) Framework: An emerging view of early phonetic development. Journal of Phonetics, Amsterdam, v.39, n.4, p.467-478, 2011.

QUINTANILHA-AZEVEDO, R. A formalização fonético-fonológica da interação de restrições na produção e percepção da epêntese em variedades do Português. Tese (Doutorado em Letras). Universidade Católica de Pelotas, Pelotas, 2016.

RAUBER, A. S.; RATO, A.; KLUGE, D. C.; SANTOS, G. R. dos; FIGUEIREDO, M. TP - Testes de Percepção / Tarefas de Treinamento Perceptual - Versão 3.1. 2013. Disponível em: http://www.worken.com.br/tp/ tp_instala.html. Acesso em: 13 de julho de 2020.

SCHERESCHEWSKY, L. C; ALVES, U. K. A variabilidade no desenvolvimento e no atrito linguístico: o papel da experiência individual no estudo sobre os padrões de VOT em sistemas multilíngues. Prolíngua, João Pessoa, v.14, n.1, p.146-158, 2019. 
SCHERESCHEWSKY, L. C.; ALVES, U.K.; KUPSKE, F. F. First language attrition: the effects of English (L2) on Brazilian Portuguese VOT patterns in an L1-dominant environment. Letrônica, Porto Alegre, v.10, n.2, p.700-716, 2017.

SCHERESCHEWSKY, L. C.; ALVES, U. K.; KUPSKE, F. F. Atrito linguístico em plosivas em início de palavra: dados de bilíngues e trilíngues. Revista LinguíStica, Rio de Janeiro, v.15, n.2, p.10-29, 2019.

SCHMID, M. S.; KÖPKE, B. (Eds.). The Oxford Handbook of Language Attrition. Oxford: Oxford University Press, 2019.

SCHWARTZHAUPT, B. M.; ALVES, U. K.; FONTES, A. B. A. da L. The role of L1 knowledge on L2 speech perception: investigating how native speakers and Brazilian learners categorize different VOT patterns in English. Revista de Estudos da Linguagem, Belo Horizonte, v. 23, n.2, p. 311-334, 2015.

STRANGE, W. Cross-language studies of speech perception: A historical review. In: STRANGE, W. (Ed.). Speech Perception and Linguistic Experience. Timonium, MD: York Press, 1995. p.3-45.

STRANGE, W. Automatic Selective Perception (ASP) of first and second language speech: a working model. Journal of Phonetics, Amsterdam, v.29, p.456-466, 2011.

WRIGHT, R. Perceptual cues in contrast maintenance. In: HUME, E.; JOHNSON, K. (Eds.). The role of speech perception phenomena in phonology. San Diego: Academic Press, 2001. p.251-277.

WRIGHT, R. A review of perceptual cues and cue robustness. In: HAYES, B.; KIRCHNER, R.; STERIADE, D. (Eds.). Phonetically Based Phonology. Cambridge: Cambridge University Press, 2004. p.34-57. 


\section{SOBRE OS AUTORES (AS)}

Ana Carolina Cangemi - Doutora em Linguística e Língua Portuguesa pela Faculdade de Ciências e Letras UNESP/Araraquara, com período de Estágio de Pesquisa no Exterior na Universidade de Lisboa. A autora tem experiência na área de Linguística, com ênfase em Teoria e Análise Linguística e Linguística Histórica. Suas investigações atuais concernem ao estudo da fonologia da língua portuguesa, tanto atual quanto no período arcaico, com especial interesse em aspectos relacionados a prosódia, sílaba e processos fonológicos.

Andréia Alves Cordeiro - Mestranda em Linguística pela Universidade Estadual do Sudoeste da Bahia (UESB) - Campus de Vitória da Conquista. É graduada em Fonoaudiologia pela Faculdade Única de Ipatinga (Minas Gerais) e graduação em Licenciatura em Pedagogia pela Universidade Estadual do Sudoeste da Bahia (UESB).

Carolina Lacorte Gruba - Mestranda em Linguística pela Universidade Estadual do Sudoeste da Bahia (UESB). Fonoaudióloga graduada pela Pontifícia Universidade Católica de Minas Gerais (PUC - MG). Atuação na área de linguagem, voz, audição, disfagia e motricidade orofacial. A autora desenvolve pesquisas na área de linguagem com indivíduos com síndrome de down e com crianças vítimas de violência doméstica.

Gladis Massini-Cagliari - Professora Titular no Departamento de Linguística, da Faculdade de Ciências e Letras UNESP/Araraquara. Doutora em Linguística pela Universidade Estadual de Campinas (UNICAMP), com Pós-Doutorado na University of Oxford e Livre-Docência em Fonologia, pela Faculdade de Ciências e Letras UNESP/Araraquara. É coordenadora do Grupo de Pesquisa Fonologia do Português: Arcaico \& Brasileiro. Atuou como membro do Comitê Assessor da área de Letras e Linguística (CA-LL) do CNPq (2016-2019). Atualmente, é Pró-Reitora de Graduação da UNESP. 
Heloísa Helena Ramos Santos - Professora do Governo do Estado de Rondônia. É graduada em Letras com habilitação em Língua Portuguesa pela Fundação Universidade Federal de Rondônia (UNIR) e mestranda no Programa de Pós-Graduação Mestrado Acadêmico em Letras da Universidade Federal de Rondônia (UNIR).

José Henrique Santos Tavares - Professor de Língua Espanhola no Colégio Militar de Salvador. Mestre em Letras pela Universidade Federal de (UNIR). É graduado em Letras com habilitação em Língua Espanhola pela Universidade Estadual de Alagoas (UNEAL) e especialista em Metodologia da Língua Estrangeira-Espanhol.

José Magalhães - Professor Associado IV da Universidade Federal de Uberlândia (UFU). Doutor em Letras pela Pontifícia Universidade Católica do Rio Grande do Sul (PUC-RS), com período na Tilburg University (Holanda). Coordenador nacional da Área de Fonologia, Variação e Ensino do Mestrado Profissional em Letras - ProfLetras. Coordenador Adjunto da Área de Linguística e Literatura da CAPES.

Luann Dias de Souza - Mestre em Linguística pela Universidade Federal de Uberlândia (UFU), com ênfase em Fonética e Fonologia.

Luiz Carlos Cagliari - Pesquisador Sênior do Conselho Nacional de Desenvolvimento Científico e Tecnológico (CNPq). Professor aposentado da Universidade Estadual de Campinas (UNICAMP) e professor Colaborador Voluntário do Departamento de Linguística, Literatura e Letras Modernas da Faculdade de Ciências e Letras UNESP/Araraquara, atuando principalmente no Programa de Pós-Graduação de Linguística e Língua Portuguesa dessa Instituição.

Marian Oliveira - Professora Adjunta da Universidade Estadual do Sudoeste da Bahia (UESB), docente do Programa de Pós-graduação em Linguística e do ProfLetras. Doutora em Linguística pela Universidade Estadual de Campinas (UNICAMP), área de concentração Fonética e Fonologia, com pesqui- 
sa que relaciona síndrome de Down e produção vocálica. Coordena projetos de pesquisa sobre o sistema fonético-fonológico de pessoas com síndrome de Down. Atualmente, é líder do Grupo de Pesquisas e Estudos em Síndrome de Down-Saber Down (CNPq-UESB).

Natália Cristine Prado - Professora Adjunta do Departamento Acadêmico de Letras Vernáculas da Fundação Universidade Federal de Rondônia (UNIR) e do Programa de Pós-Graduação Mestrado Acadêmico em Letras. Doutora em Linguística e Língua Portuguesa pela Faculdade de Ciências e Letras UNESP/ Araraquara, com período de Estágio de Pesquisa no Exterior na Universidade de Lisboa. A autora é líder do Núcleo de Estudos em Fonologia - NEFONO (UNIR/Porto Velho). Suas investigações atuais concernem os seguintes temas: fonologia, morfologia, ortografia, escrita e oralidade.

Patrícia Goulart Tondineli - Professora Adjunta do Departamento Acadêmico de Letras Vernáculas da Fundação Universidade Federal de Rondônia (UNIR) e do Programa de Pós-Graduação Mestrado Acadêmico em Letras. Doutorado em Letras e Linguística pela Pontifícia Universidade Católica de Minas Gerais (PUC - MG). Coordena o Projeto de Pesquisa Línguas Indígenas do Cone-sul de Rondônia e o Grupo de Pesquisa em Estudos da Língua(gem) - GPEL.

Thaís Holanda de Abreu-Zorzi - Doutora em Linguística e Língua Portuguesa pela Faculdade de Ciências e Letras UNESP/Araraquara. É Licenciada e Bacharel em Letras (Português-Espanhol) pela mesma Instituição. Tem experiência na área de Linguística, com ênfase em Teoria e Análise Linguística e Linguística Histórica, trabalhando com temas relacionados à fonologia da língua portuguesa atual e do período arcaico. Suas investigações focalizam questões de ordem prosódica e processos fonológicos do português.

Ubiratã Kickhöfel Alves - Professor do Departamento de Línguas Modernas da Universidade Federal do Rio Grande do Sul (UFRGS). Doutor em Letras - Lingüística Aplicada pela Pontifícia Universidade Católica do Rio 
Grande do Sul (PUC - RS), com estágio na University of Massachusetts Amherst, Estados Unidos. Ademais, seu estágio de pós-doutorado ocorreu na Universidad Nacional de Mar del Plata, Argentina.

Vera Pacheco - Professora titular da Universidade Estadual do Sudoeste da Bahia (UESB). Doutorado em Linguística pela Universidade Estadual de Campinas (UNICAMP) e pós-doutorado pela Faculdade de Ciências e Letras UNESP/Araraquara. 


\section{放UNIR}

A Fundação Universidade Federal de Rondônia (UNIR) é uma instituição pública de ensino superior criada em 1982. Ao longo de aproximados 40 anos, as ações de ensino, pesquisa e extensão formaram profissionais qualificados para atuação em todas as esferas da sociedade e do mercado de trabalho. A partir do ano 2000, com o início da oferta de cursos de Pós-Graduação, essa ação foi sendo ampliada, sendo ofertados, atualmente, 24 mestrados e 04 doutorados, abrangendo diversas áreas do conhecimento e priorizando pesquisas atinentes às questões ambientais, sociais, educacionais, culturais, econômicas e geográficas da Amazônia e especialmente de Rondônia. Como política de apoio e fortalecimento à Pós-Graduação e à pesquisa na Universidade, a Pró-Reitoria de Pós-Graduação e Pesquisa (PROPESQ) instituiu a publicação de livros elaborados pelos programas de Pós-Graduação, como atividade de divulgação e compartilhamento dos resultados das pesquisas produzidas por pesquisadores desta Instituição, tendo a Editora da Universidade Federa de Rondônia (EDUFRO), como unidade sistematizadora de todas as produções. Dessa forma, esta coleção, composta por 13 livros elaborados cada um por um PPG da UNIR, apresenta temas e abordagens disciplinares e transdisciplinares, divulga os resultados das pesquisas elaboradas nessa Instituição e aproxima a UNIR das Instituições Estaduais, Municipais e de toda a Sociedade.

Maria Madalena de Aguiar Cavalcante - Diretora de Pós-Graduação Artur de Souza Moret - Pró-Reitor de Pós-Graduação e Pesquisa

O desafio da Fundação Universidade Federal de Rondônia no ensino de graduação e de Pós-Graduação nunca foi tão grande, principalmente a partir dos recursos cada vez menores. Nesta pandemia por covid-19, o desafio foi não parar e a Pós-Graduação da UNIR não parou: defesas de dissertações e teses tornaram-se on-line e as produções acadêmicas-científicas não cessaram. Estes 13 livros da Coleção Pós-Gradução são a demonstração de que o esforço para o crescimento e a consolidação se mantém firme e constante. O futuro da Pós-Graduação na UNIR é o resultado das ações articuladas entre todos os atores, com maior abertura para a sociedade e para os setores públicos e com um grande objetivo que nos motiva, o de contribuir na formação em excelência de professores e pesquisadores nos países limítrofes. Os resultados nos colocam em papel de destaque na Amazônia e é isso o que desejamos: ser uma Instituição pública e gratuita, com forte apoio da sociedade para a oferta de cursos e formações que promovam o Desenvolvimento Regional e Sustentável do Estado de Rondônia

Marcele Regina Nogueira Pereira - Reitora
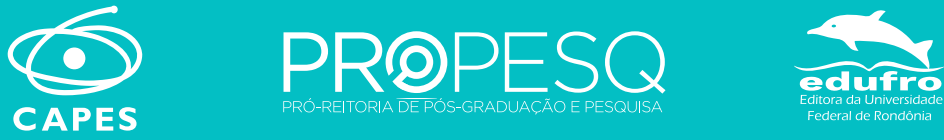